Portland State University

PDXScholar

$1-1-2011$

\title{
Chronology and Ecology of Late Pleistocene Megafauna in the Northern Willamette Valley, Oregon
}

Daniel McGowan Gilmour

Portland State University

Follow this and additional works at: https://pdxscholar.library.pdx.edu/open_access_etds Let us know how access to this document benefits you.

Recommended Citation

Gilmour, Daniel McGowan, "Chronology and Ecology of Late Pleistocene Megafauna in the Northern Willamette Valley, Oregon" (2011). Dissertations and Theses. Paper 416.

https://doi.org/10.15760/etd.416

This Thesis is brought to you for free and open access. It has been accepted for inclusion in Dissertations and Theses by an authorized administrator of PDXScholar. Please contact us if we can make this document more accessible: pdxscholar@pdx.edu. 
Chronology and Ecology of Late Pleistocene Megafauna in the Northern Willamette Valley, Oregon

\title{
by
}

Daniel McGowan Gilmour

A thesis submitted in partial fulfillment of the requirements for the degree of

\author{
Master of Arts \\ in \\ Anthropology
}

Thesis Committee:

Virginia L. Butler, Chair

Kenneth M. Ames

Jim E. O'Connor

Portland State University

(C)2011 


\begin{abstract}
This study is an investigation of the timing of extinction of late Pleistocene, large bodied mammalian herbivores (megafauna) and of the environment in which they lived. The demise of the megafauna near the end of the Pleistocene remains unexplained. Owing to potential human involvement in the extinctions, archaeologists have been particularly concerned to understand the causes for faunal losses. Our current lack of understanding of the timing and the causes of the extinctions in North America may result from a deficiency in understanding the histories of each individual species of extinct animal on a local level. Detailed regional chronologies of fauna are necessary for comparison with paleoenvironmental and archaeological data to help sort out causes for extinction.
\end{abstract}

The Willamette Valley of western Oregon has long been noted for finds of megafauna, though records have not been synthesized since the early $20^{\text {th }}$ century and these materials have remained largely unstudied. In this thesis, I first create a catalog of extinct megafauna recovered from the Willamette Valley. Next, using material from the northern valley, I employ AMS radiocarbon dating, stable isotope $\left(\delta^{13} \mathrm{C}\right.$ and $\left.\delta^{15} \mathrm{~N}\right)$ analyses, and gross inferences based on the dietary specializations and habitat preferences of taxa in order to reconstruct environments and to develop a local chronology of events that is then arrayed against archaeological and paleoenvironmental data.

The results of this study indicate that megafaunal populations in the northern Willamette Valley were contemporaneous with the earliest known human populations of the Pacific Northwest, as well as later populations associated with the Clovis Paleoindian 
Horizon. Consistent with the overkill hypothesis, radiocarbon ages span the length of the Clovis window, but no ages are younger than Clovis. Moreover, all radiocarbon ages are older than or contemporaneous to the onset of the Younger Dryas Stadial. No age ranges fall exclusively within the Younger Dryas. Comparison of megafaunal ages and paleoenvironmental records support the view that climate change contributed to local animal population declines. Prior to $\sim 13,000 \mathrm{cal} \mathrm{BP}$, the Willamette Valley was an open environment; herbivores mainly consumed $\mathrm{C}_{3}$ vegetation. The timing of the loss of megafauna coincides with increased forested conditions as indicated by regional paleoenvironmental reconstruction. As the timing of megafaunal decline correlates with Clovis, the onset of the Younger Dryas, and increased forested conditions, it is not possible with the data currently available to distinguish the cause of extinction in the Willamette Valley. The age ranges of the fauna coupled with taphonomic and geologic context indicate that the fauna are autochthonous to the Willamette Valley; they do not represent ice rafted carcasses or isolated skeletal elements transported from elsewhere during late Pleistocene glacial outburst floods. 


\section{DEDICATION}

To Dad, who every summer packed us all into the family roadster and drove us back and forth across the western United States to tour cliff dwellings, national parks, petrified forests, and fossils. Those grand adventures instilled within me a fascination with archaeology and the historical sciences. Thank you. 


\section{ACKNOWLEDGEMENTS}

After a decade of odd jobs, in 2003 I enrolled as an undergraduate anthropology major at the University of California at Santa Cruz. There I encountered Professors Diane Gifford-Gonzalez and Judith Habicht-Mauche. They immediately befriended, mentored, and encouraged me to pursue graduate studies in archaeology. I am forever grateful for the kindness, friendship, and direction they have shown me.

My parents have been an unwavering source of encouragement and support. They have always been there and over the last decade have helped me through college, graduate school, and now parenthood. I love you both and appreciate all you have done/do for me.

My wife, Stacy Schneyder, is wonderful. She is the most loving, incredible, brilliant person I have ever met. We have been together since I dropped her on her head on the dance floor on the night we met during the annual meeting of the Society for California Archaeology. Stacy and our kids, Payson and Cade, have been very patient with me the last few years and have provided me the time to see this thesis through. I love you, Stacy, and our children more than I can express.

There is so much to say about my advisor, Professor Virginia Butler. Rarely does one encounter someone who is so selfless and so dedicated to helping other human beings (and salmon). Her devotion to her students is unparalleled and extends far beyond what is required. She spent countless hours over the last several years helping me write grant applications, prepare conference presentations, conduct field visits, reviewing drafts of this document, and executing a host of other actions that were necessary to bring this project to a successful conclusion. Thank you for everything. 
A host of other persons contributed to this project. From my initial application for graduate studies to the day I submitted the paperwork to graduate, the Anthropology Department's coordinator, Connie Cash, was always there to encourage, help, and prod me towards the finish line. Greg Hodgins and the NSF-Arizona AMS Lab provided me the opportunity to visit the lab and learn the AMS dating process. Special thanks to Greg for the hospitality he showed me while I was in Tucson. The quality of the thesis was improved through conversations with Martin Adams, Ken Ames, Edward Byrd Davis, Dave Ellis, Jim O’Connor, Stacy Schneyder, and Paul Solimano. I relied upon Martin Adams, Tim Gilmour, Rorie Perkins, and Paul Solilmano's technical skills in order to compensate for my own shortcomings in GIS and Illustrator. The fossil collections manager at the University of Oregon, Edward Byrd Davis, fielded a thousand questions from me over the last few years. He was instrumental in bridging the gap between archaeology and paleontology. Collaboration with Doug Kennett and Brendan Culleton at the University of Oregon immeasurably improved the quality of the isotopic analyses of this study. Over the last two years, I repeatedly consulted paleontologists Greg McDonald, Eric Scott, Russ Graham, Jeffrey Saunders, Aisling Farrell, and Chris Shaw regarding the taxonomic assignments. They never hesitated to share their insights on Pleistocene fauna. Former UO MNCH director Larry Kittleman provided me with copies of documents from his personal records regarding paleontological investigations conducted in the 1970s. Edward Byrd Davis and Bill Orr granted permission to study the UO MNCH collections. Ron Eng provided me access to view the collections at the UWBM. John Gilpin kindly gave me access to his property and his collection. Howard Rutschman granted me access to his mammoth and then donated it to the University of 
Oregon. Martin Adams, Stacie Cearley, Tom Connolly, Dave Ellis, Patrick O’Grady, Brian O’Neill, Elizabeth Orr, Terry Ozbun, Scott Thomas, and Alison Stenger kindly provided me with copies of hard-to-find literature. My committee members, Ken Ames and Jim O'Connor, have been a constant source of advice and wisdom. Thank you to all of you!

I developed friendships with several members of the public who proved instrumental in this project. Yvonne Addington and the Tualatin Historical Society possess great passion for preserving the past. Yvonne's enthusiasm helped to inspire this project. Mike Full of McMinnville has been a relentless and lifelong advocate for documenting the Willamette Valley's Pleistocene faunal communities. Dave Ellingson from the WebSS School at Woodburn High School has striven to introduce his students to science by directly involving them in the study of Oregon's past. Thank you to each of you for your help. Each of your respective communities is fortunate to have people so committed to documenting Oregon's history and educating the public.

Over my time at PSU, I spent many hours with my mates in the Butler Lab down in the basement of Cramer Hall. Conversations with Tait Elder, Tony Hofkamp, Cassie Manning, and Alex Stevenson were always stimulating and will always be some of my fondest memories of graduate school.

Financial support for this project came from a variety of organizations and individuals. The Association of Oregon Archaeologists (AOA) and the Oregon Archaeological Society (OAS) provided grants for the radiometric study. These two organizations have a long, but often little recognized, history of providing funding for graduate research. The NSF-Arizona Lab provided funding for a bulk of the radiocarbon 
dates. I would like to acknowledge the Department of Anthropology at PSU for awarding me the Newman Fund grant. Special thanks to the PSU alumni serving on the Newman Fund Board for their continued involvement with the graduate program. In addition, Dr. Virginia Butler and my father, Larry Gilmour, monetarily contributed to the specialized analyses.

Thank you to all of you and anyone I missed! 
Table of Contents

Abstract $\quad$ i

Dedication $\quad$ iii

Acknowledgements iv

List of Tables $\quad x$

List of Figures $\quad$ xi

Chapter

1. Introduction 1

2. Background $\quad 6$

The Late Quaternary Extinctions $\quad 6$

$\begin{array}{ll}\text { The Younger Dryas Stadial } & 13\end{array}$

The Use of Vertebrates in Paleoenvironmental Reconstructions 16

$\begin{array}{ll}\text { Isotopic Studies of Paleoecology } & 18\end{array}$

$\begin{array}{ll}\text { The Suitability of Bone of Isotopic Analyses } & 21\end{array}$

Inferred Ecology and Dietary Preferences of Pleistocene Megafauna 23

$\begin{array}{ll}\text { Geographic Study Area } & 28\end{array}$

The Missoula Floods $\quad 28$

Paleoenvironment $\quad 30$

History of Megafauna Research in the Willamette Valley 32

Purported Human and Megafauna Associations in the Willamette Valley 35

3. Expectations 39

4. Methods and Materials $\quad 45$

Archival and Public Research $\quad 45$

Sample Selection $\quad 46$

Taxonomic Identifications $\quad 47$

Documentation of Paleontological Localities and Specimens 48

AMS Radiocarbon Dating $\quad 49$

Stable Isotope Analyses $\quad 53$

Bone Collagen Preservation $\quad 54$

5. Results

Archival and Public Research Results $\quad 55$

Descriptions of Specimens/Localities in Specialized Analyses 59

$\begin{array}{ll}\text { Taphonomy } & 69\end{array}$

Preservation of Bone Collagen $\quad 69$

$\begin{array}{ll}\text { AMS Radiocarbon Dating Results } & 73\end{array}$

$\begin{array}{ll}\text { Comparison of Laboratories and Pretreatment Methods } & 73\end{array}$

$\begin{array}{lr}\text { Ages of Megafauna } & 80\end{array}$

Stable Isotope Analyses Results $\quad 84$ 
6. Discussion and Conclusions 86

What is the origin/source of the paleontological remains? 86

Was the loss of local megafauna related to climate cooling of the Younger $\quad 88$ Dryas Stadial?

What was the general character of Willamette Valley late Pleistocene $\quad 90$ environments?

What is the relationship between fossil age and the record for late 91 Pleistocene vegetation change in the region?

What is the relationship between fossil age and the known timing of 94 human occupation of the Pacific Northwest?

Conclusions

Future Work

100

$\begin{array}{ll}\text { References Cited } & 102\end{array}$

Appendices:

A. Synthesis of Records of Extinct Mammalian Herbivores Reported from the 128 Willamette Valley

B. Descriptions of Paleontological Localities 143

$\begin{array}{ll}\text { C. Descriptions of Fossil Material } & 167\end{array}$

D. Photo Documentation of Fossil Material 182

E. Metric Documentation of Fossil Material 191

F. Illustrations of Measurements Employed in Metric Documentation 196

G. Radiocarbon Dating Results from Laboratories $\quad 201$

H. XAD-Purification Procedures at the Archaeometry Facility 205 


\section{List of Tables}

Table

2.1 Extinct Pleistocene Megafauna Genera of North America

3.1 Summary of Research Questions and Hypotheses

5.1 Number of Reported Finds of Large-bodied, Extinct, Mammalian

Herbivores in the Willamette Valley, sorted by County and Genera

5.2 List of Fossil Material included in Radiometric/Stable Isotope Study

5.3 Inferred Ecology of Late Pleistocene Megafauna Genera

$\begin{array}{lll}5.4 & \text { Chemistry of XAD-purified Samples } & 70\end{array}$

5.5 Compilation of all Radiocarbon Measurements 74

6.1 Distances of Paleontological Localities from Glacial Erratics 88 


\section{List of Figures}

Figure

2.1 Map of Willamette Valley, showing locations of cities and counties

5.1 Number of Specimens from each Genera Represented in this Study

5.2 Locations of Paleontological Localities included in My Study

5.3 Bivariate Plot of Atomic C:N and wt \% Collagen Yield

5.4 Probability Plot of Calibrated AMS Measurements of Post-Missoula Flood Specimens

5.5 Calibrated Age Ranges of Terminal Pleistocene Specimens

5.6 Comparison of Ages of Megafauna from Hillsboro and WoodburnLegion Park Paleontological Localities

5.7 Bivariate Plot of Stable Isotopes $\left(\delta^{15} \mathrm{~N}\right.$ and $\left.\delta^{13} \mathrm{C}\right)$

6.1 Calibrated Age Ranges of Terminal Pleistocene Megafauna Arrayed against Natural Events and Cultural Units in the Pacific Northwest

6.2 Calibrated Age Ranges of Terminal Pleistocene Megafauna Arrayed against Younger Dryas Temperature Change as known from Greenland's GISP2 Ice Core

6.3 Calibrated Age Ranges of Terminal Pleistocene Megafauna Arrayed

6.4 Plot of Diachronic Change in Stable Carbon Isotopic Values $\left(\delta^{13} \mathrm{C}\right)$ in Bison 


\section{CHAPTER 1: INTRODUCTION}

The Pleistocene/Holocene Transition (P/HT) in North America (approximately $15,000-10,000$ cal BP) is marked by the archaeological visibility of the first Paleoindian culture complexes as well as the demise of thirty-five genera of mostly large mammals. For decades, scientists have asked whether these two events were related or coincidental. Some hypotheses place blame for the extinctions on such mechanisms as hypervirulent diseases (MacPhee and Marx 1997) or the removal of keystone species (Owen-Smith 1987). Firestone et al. (2007) have recently suggested that the extinctions were triggered by the impact of a large extraterrestrial object that caused massive environmental destruction. Two main competing hypotheses have occupied center stage in the extinction deliberations: human overkill (Martin 1967, 1973, 1984a, b; Mossiman and Martin 1975) and climate change (Graham and Lundelius 1984; Guthrie 1984; King and Saunders 1984). Despite decades of debate, the matter remains unresolved (Barnosky et al. 2004; Grayson 2007; Koch and Barnosky 2006).

Grayson (2007) has recently reviewed the history of the dispute and the difficulty in reaching consensus. He finds that the extinctions are routinely assumed to have occurred simultaneously throughout the North American continent. The literature generally sees the extinctions as occurring between approximately 14,000-11,300 cal BP (calibrated calendar years before present), a period encompassing substantial climate and vegetation change, the Clovis Paleoindian Horizon from 13,250-12,800 cal BP (Waters and Stafford 2007), as well as the Younger Dryas (YD) Stadial from 12,900-11,600 cal BP (Alley 2000; Grootes et al. 1993; Stuiver and Grootes 2000). The assumption that the extinctions occurred within this timeframe permeates the literature, despite little 
empirical support. Of the thirty-five genera of animals lost at the end of the Pleistocene, less than twenty can be shown to have survived past $\sim 13,800$ cal BP (Grayson 2007). If the taxa involved did not persist into the Clovis Horizon, Clovis people cannot be held responsible for their demise (Grayson 1987, 1991, 2007).

Grayson (2007) finds the lack of resolution in the debate over both the timing and the causes of the extinctions in North America results from a deficiency in understanding the histories of each individual species on a local level. Detailed regional chronologies of fauna are necessary to compare with available climatic, vegetational, and archaeological data to help sort out causes for extinction. Dynamic histories are possible for species when samples are well-dated and coupled with detailed paleoenvironmental and archaeological work.

Other researchers offer similar commentary on the Late Quaternary Extinctions (LQE). Haynes (2009:11) agrees that the ambiguity of the chronology of the extinctions is a major deficiency hindering resolution on the actual causes of the extinctions. He writes that both accuracy and precision in the current catalog of radiocarbon dates from the Paleoindian period are too loose to specifically implicate either the appearance of human hunters or a particular climatic event as the cause for the LQE.

For McFarlane (1999), the available database of published radiocarbon dates is insufficient to constrain the extinction event(s) to either the Clovis Paleoindian window essential to models of anthropogenic overkill, or to a specific climatic event. For example, McFarlane notes the current database of radiocarbon assays cannot specify whether the LQE occurred over an extended or discrete time period. In her view, this 
shortcoming argues for a continued effort to assemble a larger body of high precision radiocarbon dates for individual species.

Other researchers offer similar sentiments. Fiedel (2009) stated that if we are to ever determine the cause(s) of the LQE, we must first accurately determine the chronology of individual species losses. Faith and Surovell (2009) recently commented on the need for more extensive research on the biogeography of individual species that can be arranged against archaeological and paleoecological data before a cause of the LQE can be ascertained.

One region suitable for such research is Oregon's Willamette Valley. Remains of a wide variety of extinct mammalian taxa have been recovered from Terminal Pleistocene and/or Early Holocene deposits (Connolly 2003a, 2003b; Cressman and Laughlin 1941; Hay 1927; McCornack 1914, 1920; Orr and Orr 1981, 2009; Orr et al. 1992; Stenger 2002a). A small portion of these fossils have been identified and even fewer dated. Some previously collected paleontological materials from the Willamette Valley sit in curation, largely unanalyzed and lacking secure dates. An unknown, but likely sizeable number, are in private collections or dispersed across local historical societies.

While little information has ever been published on these specimens, they represent a bonanza of data that hold much scientific promise and interest to the general public. The potential benefits of a study documenting the history of extinct fauna were recognized early in the history of Oregon science. While considering the possible benefits of an investigation of the paleoecology of the Willamette Valley and of possibly a coexistence of extinct genera of mammals and early peoples, McCornack (1914: 10-11) wrote, "This problem is of interest not only to the paleontologist, but it is of real value to 
the student of anthropology also. For its solution has a direct bearing upon the advent of prehistoric man upon the Pacific Coast."

The goal of this thesis is to increase our understanding of the paleoenvironment of the Willamette Valley during the late Pleistocene, with particular focus on megafauna through the creation of a multi-taxa regional sequence of extinct mammals that can be arrayed against existing archaeological and paleoenvironmental records. This project contributes to our understanding of the causes of megafaunal extinctions by developing a local chronology of events for several taxa. Moreover, a crucial component to archaeological models of Paleoindian foraging adaptations is an understanding of diversity and abundance in past faunal communities. These finds are key in reconstructing the paleoenvironment that would have been available for human exploitation during the late Pleistocene and early Holocene. These records will help us better comprehend the ecological context for Paleoindian and/or Pre-archaic forager adaptations in the Pacific Northwest and in turn provide an important record for researchers working in surrounding regions on similar questions.

In this pursuit, I have created a record of extinct mammals recovered from late Pleistocene deposits in the Willamette Valley, Oregon. Specifically, I focus on large herbivores because of their central role as prey animals in Paleoindian subsistence; and the role of Paleoindians in causing the extinctions. To better understand the historic biogeography of megafauna in the region, late Pleistocene environments, and the cause(s) of the LQE, I have synthesized all reported records of extinct taxa recovered from the Willamette Valley. I obtained AMS radiocarbon measurements on select fauna, analyzed 
stable carbon and nitrogen $\left(\delta^{13} \mathrm{C}\right.$ and $\left.\delta^{15} \mathrm{~N}\right)$ isotopes to study paleoenvironmental context, and have recorded the taphonomic and depositional context for each individual.

To address the concerns noted above related to debates on causes of extinctions, my study considers the following research questions (which are set forth more fully in Chapter 3):

1. What is the origin/source of the paleontological remains?

2. Was the loss of local megafauna related to climate cooling of the YD Stadial?

3. What was the general character of Willamette Valley late Pleistocene environments?

4. What is the relationship between fossil age and the record for late Pleistocene vegetation change in the region?

5. What is the relationship between fossil age and known timing of human occupation in the Pacific Northwest?

This thesis is arranged in the following manner. Chapter 2 outlines pertinent background information regarding the $\mathrm{LQE}$, reviews the study of vertebrate fossils and stable isotopes and their role in paleoenvironmental studies, presents the natural and cultural history of megafaunal research in the study area, and examines the suitability of bone as a substrate for isotopic analysis. Chapter 3 sets forth each research question, hypothesis, and associated expectations. Chapter 4 presents the methods and materials utilized in this study. Chapter 5 details the results of the archival and public research, sample selection, and the results of the AMS radiocarbon measurements and stable isotopic analyses. Chapter 6 summarizes the results in relation to the research questions and places the data in context of the regional archaeology and known environmental change. 


\section{CHAPTER 2: BACKGROUND}

\section{The Late Quaternary Extinctions}

Twenty thousand years ago, North America was populated by an assortment of animals that are now extinct. Many of these fauna are termed megafauna, the largest animals in the ecosystem. Following Barnosky et al. (2004), I define megafauna as animals weighing at least $44 \mathrm{~kg}$ (approximately $100 \mathrm{lbs}$ ). The last of these fauna are thought to have expired toward the end of the Pleistocene, sometime between 15,60011,500 cal BP (Koch and Barnosky 2006).

Thirty-five genera of mammals went extinct on the North American continent during the LQE, thirty of which were megafauna (Grayson 2007). Twenty-nine of these genera became extinct globally, whereas six others became extinct in North America but persisted elsewhere (Table 2.1). Kurtén and Anderson (1980), Grayson (1991), and Martin and Klein (1984) thoroughly discuss this suite of fauna. Grayson (2007), Grayson and Meltzer (2002), Haynes (2009), and Koch and Barnosky (2006) offer more succinct overviews.

While extinctions occurred at several times in the past, the LQE differ from previous episodes in that they were extraordinarily selective in North America (Alroy 1999). Specifically, the LQE primarily eliminated large and slow breeding mammals. When viewed at the species level, losses were complete for animals weighing over 1,000 $\mathrm{kg}(\sim 2,205 \mathrm{lbs}), 50 \%$ for animals weighing less than $1,000 \mathrm{~kg}$ but more than $32 \mathrm{~kg}(\sim 71$ lbs), and 20\% for fauna weighing between 32 and $10 \mathrm{~kg}$ ( 22 lbs) (Koch and Barnosky 2006). 
Table 2.1. Extinct Pleistocene Megafauna Genera of North America (after Faith and Surovell 2009 and Grayson 2007)

\begin{tabular}{|c|c|c|c|}
\hline Order & Family & Genus & Common Name \\
\hline \multirow[t]{3}{*}{ Cingulata } & Pampatheriidae & Pampatherium & Southern pampathere \\
\hline & & Holmesina & Northern pampathere \\
\hline & Glyptodontidae & Glyptotherium & Simpson's glyptodont \\
\hline \multirow[t]{4}{*}{ Pilosa } & Megalonychidae & Megalonyx & Jefferson's ground sloth \\
\hline & Megatheriidae & Eremotherium & Rusconi's ground sloth \\
\hline & & Nothrotheriops & Shasta ground sloth \\
\hline & Mylodontidae & Paramylodon & Harlan's ground sloth \\
\hline \multirow[t]{5}{*}{ Carnivora } & Ursidae & Tremarctos* & Florida cave bear \\
\hline & & Arctodus & Giant short-faced bear \\
\hline & Felidae & Smilodon & Dirktooth \\
\hline & & Homotherium & Scimitar cat \\
\hline & & Miracinonyx & American cheetah \\
\hline \multirow[t]{3}{*}{ Rodentia } & Castoridae & Castroides & Giant beaver \\
\hline & Hydrochoeridae & Hydrochoerus* & Holmes' capybara \\
\hline & & Neochoerus & Pinckney's capybara \\
\hline \multirow[t]{2}{*}{ Perissodactyla } & Equidae & Equus* & Horses \\
\hline & Tapiridae & Tapirus* & Tapirs \\
\hline \multirow[t]{10}{*}{ Artiodactyla } & Tayassuidae & Mylohyus & Long-nosed peccary \\
\hline & & Platygonus & Flat-headed peccary \\
\hline & Camelidae & Camelops & Yesterday's camel \\
\hline & & Hemiauchenia & Large-headed camel \\
\hline & & Paleolama & Stout-headed camel \\
\hline & Cervidae & Navahoceros & Mountain deer \\
\hline & & Cervacles & Elk-moose \\
\hline & Bovidae & Saiga* & Saiga \\
\hline & & Euceratherium & Shrub ox \\
\hline & & Bootherium & Harlan's musk ox \\
\hline \multirow[t]{2}{*}{ Proboscidea } & Mammutidae & Mammut & American Mastodon \\
\hline & Elephantidae & Maтmuthus & Mammoths \\
\hline
\end{tabular}

*Genus survives outside of North America

Among mammals, mainly herbivores or the carnivores that were likely dependent on them for prey went extinct (Grayson 1991). Two entire orders, Proboscidea (mammoths and mastodons) and Perissodactyla (horses and tapirs), were lost in North America. Among the artiodactyls, all species of camels, peccaries, and giant sloths perished, as did some species of deer and pronghorn. There was even an instance of pseudo-extinction at the species level (Koch and Barnosky 2006). The philogenetic relationship between Pleistocene bison (Bison antiquus) and Holocene bison (Bison bison) has historically not been well understood (McDonald 1981:38-53). These two taxa have been treated as discrete species by scholars in some instances and as sub- 
species by others. Genetic analysis now suggests that Holocene bison descended from the larger Pleistocene version (Koch and Barnosky 2006:217; Shapiro et al. 2004). This is an example of phylogenetic replacement (pseudo-extinction) rather than outright extinction (Grayson 1991).

While the LQE was selective, it was not solely limited to class Mammalia. Nineteen genera of birds and even a single species of tree disappeared (Grayson 2007). Nonetheless, large-bodied mammals were particularly affected. None of the largest mammals survived.

For decades, scientists have attempted to explain the causes of these extinctions (Martin and Klein 1984), developing multiple hypotheses. Most suppose that humans either directly or indirectly caused the extinctions. Two competing hypotheses dominate the literature: human overkill or climate change. Other suppositions receive less attention in the literature but nonetheless bear on understanding the debate and the archaeology of the $\mathrm{P} / \mathrm{HT}$ in North America.

Firestone et al. (2007) suggested that the extinctions were triggered by the impact or detonation of a large extraterrestrial object at approximately 12,900 cal BP. This hypothesis, christened "ET Impact", is posited to have caused massive environmental changes and ecological reorganization that contributed to the YD cooling (an approximately 1,300 year return to near glacial conditions from $\sim 12,900-11,600$ cal BP), contributed to the megafaunal extinctions, advanced rapid adaptive shifts among Paleoindians, and caused major declines in human populations. Evidence for this event comes in the presence of a black, carbon-rich layer overlaying approximately fifty Clovis-aged Paleoindian archaeological sites in North America. This layer is composed 
of constituents considered evidence of ET impact: magnetic grains with iridium, magnetic microspherules, charcoal, soot, carbon spherules, glass-like carbon containing nanodiamonds, and fullerenes with ET helium.

The ET Impact hypothesis has recently been criticized in a series of papers. Surovell et al. (2009) were unable to replicate the findings of impact markers in their reanalysis of sediments from some of the same locales included in the original study. An effort to discern geochemical evidence of an impact event through the analysis of continental black mat sections and marine cores also proved unsuccessful (Paquay et al. 2009). Marlon et al. (2009) found no evidence of widespread wildfires at 12,900 cal BP as maintained by the ET Impact hypothesis. Meltzer and Holliday (2010) have posited that the supposed decline in human populations at 12,900 cal BP is actually a function of sampling bias, geomorphic processes, and radiocarbon plateau effects. The ET Impact hypothesis has only recently been introduced into academic circles and the debate over it will likely continue for some time.

MacPhee and Marx (1997) proposed another extinction hypothesis dubbed "hyperdisease." This position maintains that humans and/or dogs introduced hypervirulent and lethal diseases to animal populations in North America. Native fauna are presumed to have lacked immunity to these diseases and therefore suffered rapid, catastrophic die-offs. In accord with hyperdisease, the extinctions should follow a first contact pattern similar to the blitzkrieg or human overkill model in which animal communities are eliminated in face of advancing human groups roughly migrating from northwest to southeast as part of early colonization. This model is useful in that it clarifies how human migrants into the continent could have quickly affected native faunal 
communities without leaving physical evidence of predation (Scott 2010). Unfortunately, the hyperdisease model as currently conceived would produce little visible evidence, thus is hard to empirically test. Importantly, it is unknown whether a single disease is capable of affecting such a broad range of species as those lost during the LQE (Koch and Barnosky 2006).

The "keystone herbivore" hypothesis is a fourth explanation for the LQE (OwenSmith 1987). This hypothesis does not specify the direct cause for initial megafaunal losses, but rather focuses on ecosystem impacts. Owen-Smith maintains that the largest animals, the megaherbivores such as mammoths and mastodons, were the keystones to maintaining the diverse mosaic of vegetal communities that characterized Pleistocene flora. With the removal of a few species of mega-mammals from the ecosystem, floral systems underwent a drastic restructuring with a cascade of side effects. The newly emerging system that replaced previous vegetal communities proved incapable of supporting the many other groups of animals whose subsistence depended upon the former diverse environment. A flaw with the keystone hypothesis is that it necessitates an earlier date for the extinction of the megaherbivores than for other extinct taxa. The chronological evidence does not support this hypothesis (Barnosky et al. 2004; Koch and Barnosky 2006), although many scholars appreciate the possibility that extinctions could be linked to ecosystem scale disruptions (Haynes 2002).

Two main contending hypotheses have been at the core of extinction debates. Climate change is one of the two leading explanations for the LQE (Graham and Lundelius 1984; Guthrie 1984; King and Saunders 1984). Climatic trends during the $\mathrm{P} / \mathrm{HT}$ in North America are complex, but the period is marked by a general tendency 
towards warming sometimes punctuated by cold reversals. Associated with this climatic shift were adjustments in several environmental parameters, such as moisture and the composition of vegetal communities (Scott 2010). This was large-scale biotic reorganization featuring alterations in species composition and the establishment of new plant communities. As North America underwent this radical ecological sorting, organisms were impacted. Proponents of climate change maintain that the newly emerged ecosystems could not support the former biomass. Some animals, especially large mammals, could not adapt and became extirpated or went extinct globally.

Climate change is not a single coherent concept, but rather subsumes complex factors. Guthrie (1984) proposed that the interspersed mosaics that characterized Pleistocene vegetative communities were replaced by a more uniform zonal distribution of plant communities coupled with increased seasonality that diminished the carrying capacity of herbivores. In another version of climate change known as coevolutionary disequilibrium, Graham and Lundelius (1984) maintained that rapid climate shifts disrupted intricate resource partitioning between taxa that had become dependent upon one another via reciprocal selective forces. Other climate change scenarios posit that extinctions were triggered by general reductions and/or fragmentation of habitats that could no longer support the biomass (Barnosky 1986; King and Saunders 1984), an increased degree of competition for dwindling resources brought about by late Pleistocene immigrant species such as bison (Scott 2010), or decreased reproductive success in large mammals as a result of increased seasonality (Kiltie 1984).

The climate change position faces a major hurdle. At least a portion of the LQE occurred during the Bølling-Allerød Interstadial, a period of warming following the Last 
Glacial Maximum and lasting from 14,700-12,900 cal BP (Kennett et al. 2008). The Bølling-Allerød was only one of several interstadials that occurred during the Pleistocene. However, none of these prior climatic transitions resulted in widespread extinctions (Scott 2010). If the end Pleistocene climate change accounts for the demise of the megafauna, it must be shown to have been a unique form of climatic adjustment. Paleoecological records do not support such a transition (Barnosky et al. 2004). In sum, climate change hypotheses fail to explain why similar extinctions did not occur during earlier intervals of inter-glacial environmental shifts during other periods of the Pleistocene.

The last of the major hypotheses that attempt to explain the LQE is "overkill." The overkill model maintains that intentional human hunting accounts for the demise of megafauna (Fiedel and Haynes 2004; Haynes 2007; Martin 1967, 1973, 1984a, b; 2005). Alternate scenarios either propose a protracted loss of prey due to prolonged predation by humans or a rapid loss of naïve and vulnerable prey species in the face of coordinated attacks from human hunters, an event termed "blitzkrieg" (Martin 1973, Mosimann and Martin 1975). The process may have been characterized by gradual attrition over thousands of years in the former situation, or occurred swiftly in a few centuries in the later.

The overkill model faces a series of obstacles that its proponents have been unable to address. First, it fails to explain the wider extinctions of animals, both avian and mammalian, that were not prey species (Grayson 1991; Owen-Smith 1997). Next, there is a paucity of archaeological evidence to support it (Grayson and Meltzer 2002). If humans were responsible for wiping out whole species, there should be some, if not 
strong, evidence in the archeological record of kill/butchery locales. Through a vetting of the zooarchaeological record of purported human-megafauna interactions, Grayson and Meltzer (2002) could identify only 14 archaeological sites with strong evidence of Clovis-aged archaeological materials in association with extinct Pleistocene mammals. Moreover, only two genera are represented in these 14 instances, Mammuthus (12 cases) and Mammut (two cases). Additionally, computer simulations refute some permutations of overkill (Brook and Bowman 2002).

The above hypotheses attempt to account for the causes of the LQE. In the ongoing debate, some researchers seek answers in ecological change while others emphasize the human role in the losses. However, the causes of the extinctions continue to be a matter of contention.

\section{The Younger Dryas Stadial}

Given the timeframe encompassed by this study, an understanding of the YD is necessary. Following the termination of the last Glacial Maximum at $\sim 19,000$ cal BP (Yokoyama et al. 2000), global climate shifted from a cold glacial state to a period of warming known as the Bølling-Allerød Interstadial. This trend in warming was then punctuated by a sharp return to near glacial conditions termed the YD Stadial. The YD lasted for approximately 1,200-1,300 years, or from $~ 12,900-11,600$ cal BP, with mean annual temperatures approximately $15-16^{\circ} \mathrm{C}$ cooler than present (Alley 2000; Grootes et al. 1993; Stuiver and Grootes 2000). Furthermore, this cold period appears to have been highly seasonal, with an $18-20^{\circ} \mathrm{C}$ oscillation between winter and summer. Winter lows were approximately $24^{\circ} \mathrm{C}$ cooler than present, while summer lows were between $5-10^{\circ} \mathrm{C}$ cooler than present (Meltzer and Holiday 2010). 
YD cooling has long been discussed but still is not fully understood. Knowledge of the YD is primarily known through Greenland's GRIP and GISP2 ice cores (Alley 2000; Grootes et al. 1993; Stuiver and Grootes 2000). Viau and Gajewski (2007:264) stress that those cores are only single data points and there are limits to what can be learned from them. Meltzer and Holliday (2010) emphasize that YD climate and climate changes as understood in Greenland are not exact analogs for coeval climatic fluctuations in other regions, such as North America.

YD cooling has been detected in Pacific Northwest paleoenvironmental studies. Using isotopic data derived from a speleothem in the Klamath Mountains of southern Oregon, Vacco et al. (2005) indicated that regional climatic cooling occurred synchronously with YD climate change elsewhere in the Northern Hemisphere. A paleoenvironmental study (Adams 2008) conducted in the Willamette Valley that utilized fossil beetle species as climatic indicators also tentatively suggests a cooler period and increased seasonality during the YD time interval. Of note, while both studies indicated that the YD was characterized by a general cooling trend, a considerable degree of temperature oscillation in time and space is also indicated.

Geologic studies in western Oregon have also recognized climate change during the P/HT, in the general time frame of the YD. O'Connor et al. (2001:5, 6, 15-19) noted a thin, but widespread, unit of sand and gravel (unit Qg1) indicative of aggradation by braided stream systems of sediment load derived from major Cascade Range tributaries across the Willamette Valley. Much of the amplified sediment load probably resulted from increased landsliding, periglacial processes, and physical weathering during episodes of glacial climates. Chronologically, this period of increased sedimentation is 
not well constrained, but post-dates $(<15,000 \mathrm{cal} \mathrm{BP})$ the Missoula Floods (see discussion below). A radiocarbon measurement on fluvially transported wood returned an age of 14,466-13,788 cal BP (Beta-98724). This age pre-dates the recognized onset of the YD at 12,900 cal BP, but temporal resolution of this Willamette Valley aggradation event is less than ideal.

Wampler (2004:10, 25-30) studied geomorphic responses to climatic, anthropogenic, and fluvial change along the Clackamas River in the northern Willamette Valley. His studied showed that periods of aggradation and erosion typically occur during transitions between climatic episodes or during times of cool climate and glacial advance. Clackamas River terrace Qt3 is characterized by increased aggradation and the formation of braided channels, conditions resulting from sediment input increasing beyond the capacity of the Clackamas River. This situation is what would be expected from glacial advance in the Cascade Range. Radiocarbon dates associated with Clackamas terrace Qt3 correlate well with YD cooling, suggesting that this period of increased sediment load occurred either during or immediately following the YD. As evidence of aggradation during the YD is present elsewhere in the Pacific Northwest, Wampler (2004:30) suggests that the increased aggradation along the Clackamas River is linked to a climatic trigger that affected the entire Pacific Northwest region, as opposed to a purely local phenomenon.

Personius et al. (1993) studied a regionally extensive, low terrace system present in several rivers in central Oregon's Coast Range. They detected a regional aggradation episode dating to the P/HT. While the specific cause of the aggradation episode could 
not be identified, they suggested that the studied terrace resulted from climatically induced sediment increases that affected multiple Coast Range streams during the P/HT.

\section{The Use of Vertebrates in Paleoenvironmental Reconstructions}

The reconstruction of past environments based upon mammalian faunal representation has an established record in paleoecological studies (Grayson 1981; Lundelius 1964; Shotwell 1955). Such efforts are known to be most effective when considering fauna that occupy a narrow climatic range, such as is the case with microfauna (Grayson 2000). Despite this, Churcher and Wilson (1990) summarized the potential for large vertebrates as tools in reconstructing past climates and environments. They noted that large, terrestrial vertebrates, such as megafauna, are useful in reconstructing paleoenvironmental communities on a broad regional scale. Churcher and Wilson (1990) noted that large, terrestrial vertebrates are especially suitable in distinguishing between open (e.g., grassland) vs. closed (e.g., forest) environments.

Several case studies highlight the paleoenvironmental knowledge that can be gleaned from large mammalian datasets. Guthrie $(1968,1990)$ reconstructed aspects of paleoenvironments based upon gross patterns of large mammal representation in Alaska. His work addressed such question as: what species of animals were present, at what densities, and why a particular fauna appeared (Guthrie 1968)? From his reconstruction of mammalian herbivore communities, Guthrie inferred vegetative and climatic conditions in Alaska during the late Pleistocene.

In addition, Guthrie (2006) demonstrated the efficacy of arraying paleoenvironmental data against the waxing and waning of radiometrically dated species abundances. He organized dates of mammalian fauna across the P/HT against ecological 
(climate, vegetation communities) and archaeological data demonstrating that groups of large mammal species (including humans) responded to climate change in unique and independent ways. Ukkonen et al. (2007) revised late Pleistocene era paleoecology in Scandinavia. The researchers charted the distribution of radiocarbon dated mammoth remains alongside the likely extent of glaciers from the same period. This enabled them to revise the known geographic range of breeding mammoth populations and subsequently the environment that would have supported these species, an interpretation further supported by isotopic analysis. In addition, Ukkonen et al.'s work helped to revise the chronology of glaciations in Sweden.

The above review is not an exhaustive history of the use of vertebrate fauna in the study of paleoecology, but shows the value of faunal histories to paleoenvironmental reconstruction. While the data collected from this approach can sometimes be fairly general, projects such as Guthrie's (2006) have helped researchers to possibly identify local climatic causes for faunal extinctions, and thus allow some resolution of the ongoing debate furthered by Martin (2005) and others (Haynes 2007) who emphasize the human role in the losses.

The ecological insights gained through the analysis of large, mammalian herbivores can be relatively coarse-grained. Despite this, such data makes a significant contribution to the study of the paleoenvironment of a region where little information is known of a particular time period. Given the paucity of data currently available on the archaeology, paleontology, and paleoenvironment of the P/HT in the Willamette Valley, even such coarse-grained information can make a significant contribution to our knowledge of the P/HT. 


\section{Isotopic Studies of Paleoecology}

The study of stable isotopes has proven useful in the reconstruction of past environments (Koch 1998). Isotopes in bones and teeth of herbivores represent preserved chemical signatures of the feeding habits of animals, which in turn reflect the distribution of plants in the ecosystem. As such, stable isotopes are a direct measure of the diet and ecology of ancient fauna (Ambrose and Norr 1993; Bocherens 2003). Carbon and nitrogen are two isotopes derived from diet that can be used to investigate past ecosystems (DeNiro and Epstein 1978; Schoeninger and DeNiro 1984).

The carbon isotopic signatures of land plants are a direct result of the photosynthetic pathway they utilize (Koch 1998). All plants exploit one of three photosynthetic pathways: the $\mathrm{C}_{3}$ or Calvin-Benson pathway, the $\mathrm{C}_{4}$ or Hatch-Slack pathway, or crassulacean acid metabolism (CAM). $\mathrm{C}_{3}$ plants are trees, shrubs, most dicots, browse, and higher latitude grasses with cool growing seasons. These organisms are enriched in the light carbon isotope ${ }^{12} \mathrm{C}$ which results in a relatively more depleted $\delta^{13} \mathrm{C}$ ratio $\left({ }^{13} \mathrm{C} /{ }^{12} \mathrm{C}\right.$ ) of approximately $-26.5 \%$ (Ehleringer and Monsoon 1993; Koch 1998; O’Leary 1988; Smith and Epstein 1971). Tropical, warm-season sedges and grasses utilize the $\mathrm{C}_{4}$ pathway and are enriched in the heavy carbon isotope ${ }^{13} \mathrm{C}$, resulting in a relatively less depleted $\delta^{13} \mathrm{C}$ ratio, approximately $-12.5 \%$ (Ehleringer and Monsoon 1993; Koch 1998; O'Leary 1988; Smith and Epstein 1971). CAM plants, which consist of succulents such as cacti, are restricted to xeric habitats and rarely comprise any sizeable portion of an herbivore's diet (Coltrain et al. 2004). As such, CAM plants are not considered further in this discussion. 
This isotopic signal is preserved in the tissues of herbivores that have consumed plants. However, there is consistent fractionation in the expression of this signal in bone collagen as compared to vegetation. In bone collagen, the carbon isotopic expression is offset by 2-5\% (Ambrose and Norr 1993; Ambrose and DeNiro 1986; Balasse et al. 1999; van der Merwe 1982). The result is a bone collagen $\delta^{13} \mathrm{C}$ value of approximately $-21.5 \%$ for herbivores that feed primarily on $\mathrm{C}_{3}$ vegetation and a $\delta^{13} \mathrm{C}$ value of approximately $-7.5 \%$ for herbivores that feed primarily on $\mathrm{C}_{4}$ vegetation.

$\delta^{13} \mathrm{C}$ values are frequently employed in studies that investigate the diet and ecology of faunal communities. As stable carbon isotopes provide information on the types of plants consumed, a common goal of such studies is to assess the contribution of $\mathrm{C}_{3}$ vs. $\mathrm{C}_{4}$ in the diet of herbivores. In addition, $\delta^{13} \mathrm{C}$ ratios of terrestrial herbivores can inform on the general structure of the vegetative communities that they inhabited. Plant communities in forested areas are characterized by greater depletion in $\delta^{13} \mathrm{C}$ values (approximately -2 to -5\%) as compared to open environments (Coltrain et al. 2004; van der Merwe and Medina 1991). As such, it is possible to identify fauna that occupied open vs. forested environments based on the $\delta^{13} \mathrm{C}$ value of their tissues (Cerling et al. 2004).

Stable nitrogen isotopes (the $\delta^{15} \mathrm{~N}$ ratio) are more complex as compared to carbon. In a simple linear food chain, $\delta^{15} \mathrm{~N}$ values are linked to trophic level. Nitrogen isotopes elevate 3.0-4.2\% per trophic level (DeNiro and Epstein 1981; Minagawa and Wada 1984; Schoeninger and DeNiro 1984). However, bone collagen $\delta^{15} \mathrm{~N}$ values can vary within a single trophic level or even within a single taxon (Szpak et al. 2010). A variety of metabolic and external factors potentially account for this variation: herbivore $\delta^{15} \mathrm{~N}$ 
values are known to increase with aridity (Gröcke et al. 1997; Heaton et al. 1986; Sealy et al. 1987); digestive physiology in ruminant vs. non-ruminants (Bocherens et al. 1996; Coltrain et al. 2004); natural variation in the isotopic composition of plants (Shoeninger and DeNiro 1984); urea recycling to conserve nitrogen (Sealy et al. 1987); if the animal was young (suckling age) and subsisting off of mother's milk it would score a trophic level higher (Bocherens 2003); or differences in diet (Bocherens 2003; Szpak et al. 2010).

Recent studies have shown that analysis of two or more stable isotopes can inform on the structure of past faunal communities (Bocherens 2003; Bocherens et al. 1996; Bocherens et al. 1997; Coltrain et al 2004; France et al. 2007). Commonly carbon, in tandem with either nitrogen or oxygen, have been successful at detecting likely resource use by herbivores in ancient ecosystems.

For example, Bocherens' (2003) study of late Pleistocene mammoth steppe fauna strongly suggested a segregation of food sources by taxa consistent with Guthrie's (1984) concept of a mosaic pattern of vegetation that provided the sustenance necessary for late Pleistocene megafauna populations. In a similar study, France et al.'s (2007) analysis of Rancholabrean fauna from Virginia identified a lack of $\mathrm{C}_{4}$ grasses in the regional environment and possible niche compaction among herbivores at the end of the Pleistocene.

In sum, stable carbon $\left(\delta^{13} \mathrm{C}\right)$ and nitrogen $\left(\delta^{15} \mathrm{~N}\right)$ isotopes derived from study of ancient herbivore bone tissues can be linked to diet and in turn paleoenvironments. The study of stable isotopes has proven useful in the reconstruction of past environments and in identifying dietary choices among herbivores. The study of the isotopic 
biogeochemistry of extinct animals hence provides insights into how different organisms lived and interacted in an environment that has no modern analog.

\section{The Suitability of Bone for Isotopic Analyses}

As reviewed by Stafford et al. (1988), the suitability of bone for isotopic analyses has been questioned in the past. Bone is susceptible to degradation (diagenetic alteration/breakdown) and contamination (presence of exogenous contaminants) (Stafford et al. 1988; Taylor 1992; van Klinken 1999). Koch (1998) wrote that given its susceptibility to isotopic alteration, bone is generally considered a poor substrate for analysis unless the specimens are unusually well preserved Pleistocene and Holocene materials. Recent studies (Bocherens et al. 2004; Coltrain et al. 2004; France et al. 2007) have employed a series of measures to assess the integrity of the collagen of each bone specimen. Although it is not possible to detect degradation and/or contamination in all instances, the protocols discussed below can provide a clearer indication of cases in which preservation is sub-optimal.

The elemental properties of extracted bone collagen can be examined to assess specimen integrity and suitability for isotopic analysis. Work by Ambrose (1990) and reviewed by van Klinken (1999) put forth standards for ranges in nitrogen content (expressed in weight $\% \mathrm{~N}$ ) and carbon (expressed in weight \% C) that are expected of non-contaminated, well-preserved bone collagen. These values are unique to bone collagen. An abnormal measure of either ratio is considered an indication of the presence of non-collagenous organic or inorganic substances in the collagen extract. Percent total carbon yields in collagen should range between $\sim 30-45$ wt $\% \mathrm{C}$. Meanwhile, nitrogen content is expected to range between $\sim 11-16 \mathrm{wt} \% \mathrm{~N}$. 
The relative abundances of carbon and nitrogen in bone collagen samples can also be evaluated in order to assess sample integrity. The atomic C:N (carbon to nitrogen) ratio is widely employed as a quality control measure and is considered one of the two prime indicators of the quality of the extract from bone collagen material (van Klinken 1999). The atomic C:N ratio is a derived measure of the weight percent of carbon divided by the weight percent of nitrogen of the combusted collagen sample (DeNiro 1985; Schoeninger et al. 1989). The generally accepted atomic C:N ratio of unaltered bone collagen in modern and fossil samples is 2.9-3.6 (Ambrose 1990; DeNiro 1985).

Collagen yield is the second of the two prime indicators used in the evaluation of the quality of bone collagen which is calculated by dividing the final collagen sample weight by the starting bone sample weight and is expressed as the weight $\%$ collagen yield (van Klinken 1999). Undeteriorated original collagen should return \% collagen yields of between $\sim 1-21 \%$ of the original weight of the bone sample (van Klinken 1999). Working mainly with samples from temperate European environments, van Klinken (1999) considered collagen yields of less than $\sim 1 \%$ as not suitable for analysis.

Lastly, atomic C:N ratios and wt \% collagen yields can be examined using linear regression to inform on the integrity of the bone collagen in samples. A correlation between the two would suggest that the two samples had undergone some form of diagenesis. Unaltered samples would not be expected to have any correlation between the two as pretreatment would be expected to remove all contaminants. An absence of correlation between the atomic C:N ratios and wt \% collagen yields indicates that the samples are preserving the original biogenic signal (Bartelink 2006). 


\section{Inferred Ecology and Dietary Preferences of Pleistocene Megafauna}

Besides isotopes, the ecology and dietary preferences of extinct fauna are inferred from a variety of sources, including comparisons with modern analogs, dental and skull morphology, and the analysis of preserved dung or stomach contents (Ruez 2005). Based upon dietary specialization, herbivores can be classified as grazers, browsers, or intermediate feeders. Following Hoffmann and Stewart (1972), grazers are taxa that feed on grasses, sedges, and low herbaceous vegetation. Their diets consist of less than $25 \%$ browse. Taxa that feed on trees and shrubs are considered browsers. At least $75 \%$ of a browser's diet is concentrated on dicot foliage, tree and shrub stems and foliage, and even fruits. Taxa that feed on a mixture of grass and browse are regarded as intermediate, or mixed, feeders. As will be reviewed in Chapter 5, my study documents five genera of megafauna (Mammuthus, Mammut, Paramylodon, Bison, and Equus). This section reviews prior knowledge of the diet and habitat preferences of these taxa.

Mammoths (genus Mammuthus) have been traditionally considered grazers and indicative of open habitat (McDonald and Pelikan 2006; Webb 1992). While extant elephantids tolerate diverse habitats, from forest to woodland to savannahs to near deserts (Haynes 1991:58-61), fossil elephantids are thought to have occupied cold steppe or open grasslands with adequate water sources (Agenbroad and Mead 1996; Haynes and Klimowics 2003). Mammoths are classified as grazers based upon dental and cranial adaptations (Guthrie 1968:359; Haynes 1991:6; Webb 1992) and observations of extant species of elephant belonging to the same taxonomic family (Haynes 1991; Webb 1992). Direct evidence for mammoth diet exists with preserved dung. Dung recovered from two caves in Utah, Bechan Cave (Davis et al. 1984; Mead et al. 1986) and Cowboy Cave 
(Hansen 1980), consisted almost entirely of grasses (Poaceae) and sedges (Cyperaceae). Carbon isotope analysis that discriminated between the diets of both grazers and browsers in a shared landscape also shows that mammoths primarily consumed grasses (Koch et al. 1998; Hoppe and Koch 2006). Based on the above, mammoths are classified as grazers that occupy open environments.

American Mastodon (Mammut americanum) is generally associated with conifer (especially spruce) forest, mixed coniferous forests, deciduous forests, or parklands with bogs or swamps, ponds, marshes, and periglacial lake environments (Haynes 1991:90; Kapp 1986; Jackson et al. 1986; Mead et al. 1979; Newsom and Mihlbachler 2006; Petersen et al. 1983). The Manis Mastodon site from the Olympic Peninsula near Port Angeles, Washington, was associated with shrubby, meadow steppe and riparian wetlands featuring grasses, sedges, and willows with dense stands of cattails (Gustafson et al. 1979). Maтmut americanum is classified as a browser, which consumes principally woody vegetation (King and Saunders 1984; Haynes 1991; Newsom and Mihlbachler 2006; Webb 1992). This is supported by jaw morphology (Laub 1996), tusk curvature (Saunders 1996), contents of their digesta (Webb et al. 1992), and dentition that consisted of relatively low-crowned molars of parallel rows of nipple shaped cusps indicative of crushing twigs, leaves, and stems (Haynes 1991:4; Tobien 1996). Carbon isotope analysis supports the contention that mastodons primarily consumed $\mathrm{C}_{3}$ plants, presumably trees, shrubs and herbs (Koch et al. 1998). A study of phytoliths from three individual mastodons in Kansas contained high concentrations of grasses, suggesting that grasses were sometimes consumed (Gobetz and Bozarth 2001). Overall though, 
mastodons are typically classified as browsers adapted to hydric and mesic forested environments.

Diet and ecology of Paramylodon harlani (Harlan's ground sloth) is less well known. Paramylodon harlani has no closely related living relative, making diet reconstructions difficult. Distribution of $P$. harlani seems to be controlled by a preference for waterways adjacent to grasslands or parkland habitation (McDonald et al. 2004). It is often found with mammoth, which suggests similar habitat preference and possibly a diet dominated by grasses and sedges (McDonald and Pelikan 2006). Stock (1925) originally suggested that $P$. harlani was a grazer. However, $P$. harlani does not fit the physiology expected of either a grazer or browser. They possess simple pegged teeth that are also high-crowned (Ruez 2005). The former is considered an indication of a browsing diet while the latter is suggestive of grazing. Through an analysis of stable carbon isotopes, Ruez (2005) found P. harlani's diet in the range expected of mixed feeders, but close to the carbon isotopic composition of modern and fossil grazers, suggesting a mixed diet but one nonetheless dominated by grass. Meanwhile, their facial musculature suggests they could utilize foods of lower nutritional value, pointing to a browsing strategy (Naples 1989). While dung of $P$. harlani has never been recovered, McDonald and Pelikan (2006) considered the dung of the South American species, Mylodon darwinii, as a reasonable analog for the types of vegetation consumed by $P$. harlani. The dung of M. darwinii consisted primarily of sedges (Cyperaceae), grasses (Poaceae), and herbs associated with an open, moist, cool, boggy sedge-grassland. Coltrain et al.'s (2004) analysis of stable carbon $\left(\delta^{13} \mathrm{C}\right)$ and nitrogen $\left(\delta^{15} \mathrm{~N}\right)$ isotopes of $P$. harlani recovered at Rancho La Brea suggests their diet does not fit either a grazer (bison 
and equids) or browser (M. americanum) profile. In sum, P. harlani apparently occupied grasslands and had a mixed diet, but one still dominated by grass and sedge.

Inferences on the biology of fossil bison (e.g. Bison antiquus) are based on several lines of data, including shared dental morphologies with modern Bison bison (Guthrie 1968, Guthrie 1990; McDonald 1981). Bison bison depends almost exclusively on grazing and occupies open grassland habitat (McDonald 1981). Fossil Bison species in North America occupied a more diverse array of habitats then B. bison, ranging from semi-desert to boreal forest. This wider distribution suggests more dietary variety and ecological flexibility than exists with modern Bison (McDonald 1981). As such, feeding strategies of extinct forms possibly included some level of browse in their diet dependent upon the environmental parameters of a region (McDonald 1981:196, 205). For example, based upon limb proportions and cranial morphology, McDonald (1981:204-205) suggests the extinct $B$. antiquus was a grazer-browser more adapted to feeding on lower growing vegetation such as herbs and shrubs in savanna-wooded-steppe habitat. In a study that discriminated between $\mathrm{C}_{3}$ and $\mathrm{C}_{4}$ plant use by Pleistocene herbivores (Koch et al. 1998), Bison isotopic signals were similar to Mammuthus with a focus on $\mathrm{C}_{4}$ grasses. Rivals et al. (2007) conducted an analysis of microwear and mesowear signatures on teeth of modern and fossil Bison specimens. The mesowear portion of their study indicated significant differences in the diet of extant and fossil Bison. The microwear facet of the study indicated that the diets of extant and extinct forms were similar overall, but suggested that fossil Bison populations regularly consumed foods other than grass. The fossil Bison mesowear signatures pointed toward either a mixed feeding diet or a kind of grazing diet that differs from the short grass diet of modern plains B. bison. 
While they appear to have regularly incorporated graze in their diet, fossil Bison were capable of practicing greater dietary flexibility than their extant analogs.

Extinct varieties of the genus Equus (horses) are presumed to have been primarily grazers based upon observations of modern analogs (horses, zebra, and asses) and analysis of dental structure (MacFadden 1992). Both modern and extinct horses possess relatively high-crowned teeth, generally indicative of a grazing diet adapted to the consumption of coarse, gritty plants such as grasses (Scott 2006). While modern equids typically prefer grazing over browsing and occupy a grassland setting (Duncan 1992; Owaga 1975), modern feral horses have shown considerable plasticity in diet. They generally display little dietary specificity (Koch and Barnosky 2006) and are known to consume significant amounts of browse (Koch et al. 1998). Studies of the isotopic ecology of extinct horses from Florida could not conclusively determine equid diet (Koch et al. 1998). Koch and colleagues determined that the Pleistocene horses in their sample likely engaged in a mixed-feeding strategy, though they could not rule out the possibility that horses had grazed in a closed-canopy woodland (Koch et al. 1998). In summary, horses are generally considered grazing species adapted to open environments such as grasslands; isotopic studies and observations have indicated considerable flexibility in the diets of both extant and extinct forms.

In sum, the ecology and dietary preferences of extinct fauna are inferred from a variety of sources. Most of the taxa in this assemblage are inferred to have engaged a grazing diet. However, their grazing appears to have been flexible and they were capable of including other food sources into the diet. 


\section{Geographic Study Area}

The Willamette Valley (Figure 2.1) of northwestern Oregon is the southernmost portion of the Puget Trough, a broad structural depression that stretches from southern British Columbia to north-western Oregon (Gannett and Caldwell 1998). The valley is a broad alluvial plain bounded by the Coast Range to the west and the Cascade Range to the east. Measuring approximately $190 \mathrm{~km}$ long and averaging $40 \mathrm{~km}$ wide, it is the largest interior valley in the Pacific Northwest (O'Connor et al. 2001). The Valley is characterized by low relief and is drained by the Willamette River and its tributaries. The Willamette River's inception is near Eugene, where it flows northward to its eventual confluence with the Columbia River at the city of Portland (Glenn 1965; O'Connor et al. 2001).

\section{The Missoula Floods}

Beginning approximately 20,000 cal BP (O’Connor \& Benito 2009), the Willamette Valley underwent a series of large-scale environment changing events. At the close of the Last Glacial Maximum, a series of massive floods swept across the Columbia Plateau of Washington and poured down the Columbia River (Bretz 1925; Waitt 1980), before backing up into the Willamette Valley then exiting into the Pacific Ocean (Allison 1935). The Valley was transformed into a $100 \mathrm{~m}$ deep temporary lake (Glenn 1965). Such flooding was not a single isolated event, but rather a series of intermittent floods of varying magnitude that repeatedly inundated the valley over a period of approximately 5,000 years (O’Connor \& Benito 2009; Waitt 1980, 1985). The floods ceased with the northward retreat of the glaciers. The last flood is thought to have occurred approximately 15,000 cal BP (O’Connor \& Benito 2009). 


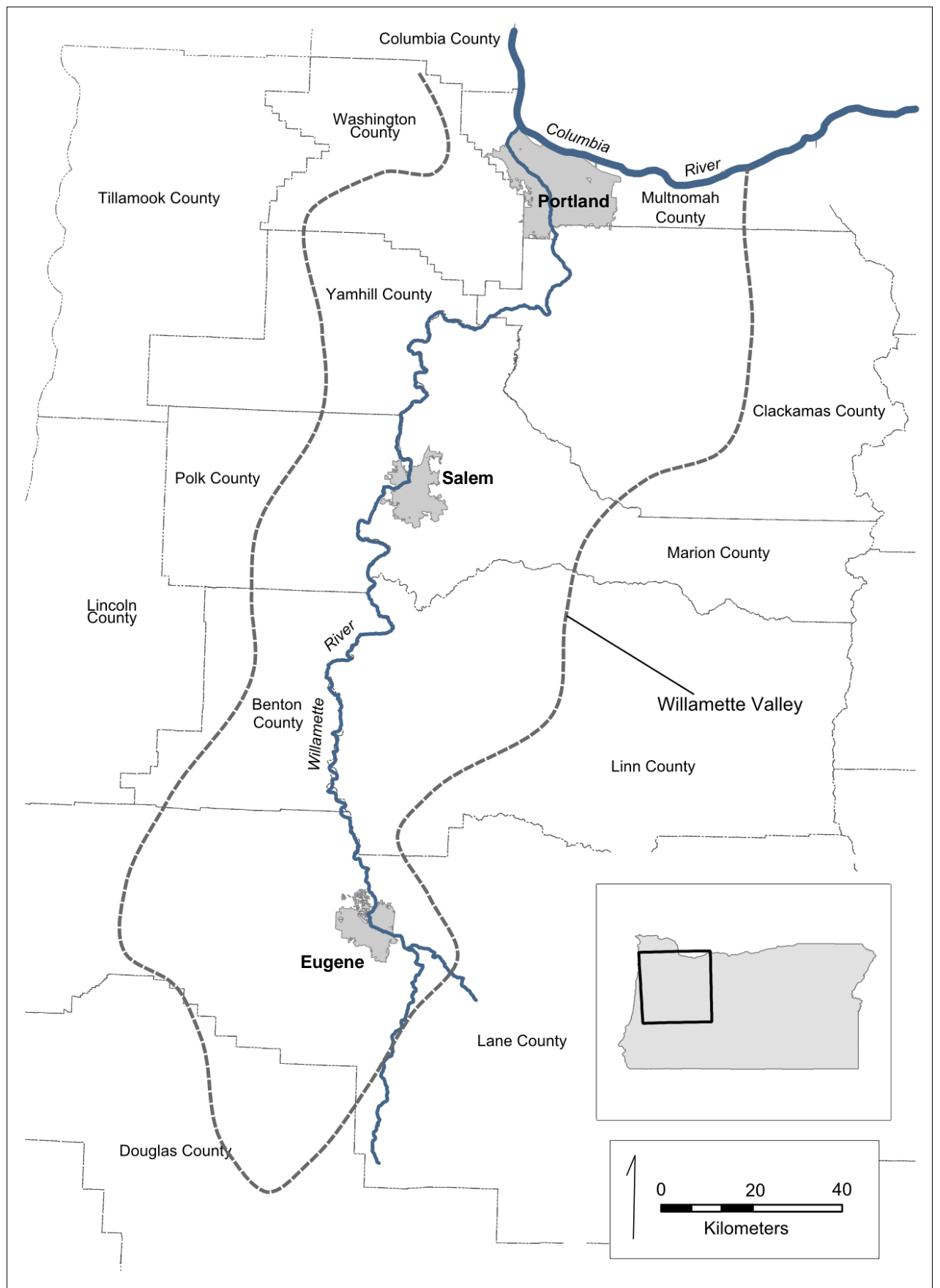

Figure 2.1. Map of Willamette Valley, showing locations of cities and counties 
The floods blanketed valley lowlands in gravel, sand, silt, and clay. The depth of these deposits often exceeds $35 \mathrm{~m}$ in the central portion of the Valley, but tapers to a thin veneer at higher elevations (O'Connor et al. 2001). Existing vegetative and animal communities were buried under these deposits. As such, the pre-15,000 cal BP valley lowlands lie entombed beneath flood deposits.

The relationship between the Missoula Floods and the remains of extinct megafauna specimens often recovered in the Willamette Valley is uncertain. In their discussion of the prehistoric distribution of bison, Verts and Carraway (1998:493) questioned whether fossil materials discovered in the valley were autochthonous (native) or transported as flotsam during a Missoula Flood event. Informal discussions between researchers in the region have also questioned the origin of the fauna.

The Missoula Floods disrupted the hydrologic cycle in the Willamette Valley. The length of time required for the valley to stabilize and become a complex ecosystem potentially suitable for a range of organisms including megafauna and humans is unknown. This period ( 15,000-11,000 cal BP) has not been much studied given the complex and dynamic geology of the post-flood landscape. Pleistocene surfaces are often deeply buried under alluvium or have been destroyed by post-flood and Holocene hydrologic adjustment that resulted in the downcutting and lateral erosion of formerly stable surfaces (Connolly et al. 1997). As a result, the archaeology, paleontology, and paleoenvironment of the P/HT are largely unknown (Aikens 1993).

\section{Paleoenvironment}

The paleoenvironmental record prior to the Holocene $(\sim 11,000$ cal BP) is sparse in the Willamette Valley proper (Walsh et al. 2010), although pollen cores have been 
studied in higher elevation sites from the Coast and Cascade Ranges (Grigg and Whitlock 1998; Worona and Whitlock 1995). A fine-grained pollen analysis conducted from a lake situated on the valley floor was recently published (Walsh et al. 2010), but it focuses on the Holocene. Much more work on Pleistocene paleoenvironments has been conducted north of the Willamette Valley.

Battle Ground Lake is located in the state of Washington, approximately $30 \mathrm{~km}$ north of the Portland Basin, the northernmost extent of the Willamette Valley, and approximately $100 \mathrm{~km}$ north of the southernmost study sample in this thesis. Barnosky (1985) and Walsh et al. (2008) reconstructed late Quaternary vegetation based on pollen and plant macro-fossil records derived during coring at Battle Ground Lake. The earliest component in Barnosky's (1985) study commenced prior to 20,000 cal BP, when the vegetative community consisted of a parkland/tundra with Picea (spruce) and Pinus (pines) as the most represented tree species. The zone is characterized by high percentages of nonarboreal pollen of Poaceae (grasses), as well as Artemisia (sagebrush) and Cyperaceae (sedges). This vegetative community persists until 14,300 cal BP.

From 14,300-13,100 cal BP, vegetation was an open forest or parkland of Picea (spruce), Pinus contorta (lodgepole pine), Alnus sinuate (Sitka alder), Tsuga mertensiana (mountain hemlock), Artemisia (sagebrush) (Barnosky 1985; Walsh et al. 2008). Poaceae (grasses) are still present but in greatly diminished numbers as compared to the previous interval of parkland/tundra.

At 13, 100 cal BP, the vegetation at Battle Ground shifts to a more wooded and warmer environment, a Pseudotsuga/Abies (Douglas-fir/fir) dominated forest with Alnus 
rubra (red alder) and Pteridium (bracken) in disturbed areas (Walsh et al. 2008). This community endures into the early Holocene (10,800 cal BP).

Only a single paleoecological study conducted on the floor of the Willamette has been published (Walsh et al. 2010). Walsh and colleagues expanded on an earlier, unpublished analysis (Pearl 1999), and reviewed Holocene fire and vegetation history through the analysis of a series of sediment cores extracted from Beaver Lake in Linn County of the central Willamette Valley. The earliest records at $\sim 11,000$ cal BP indicated the presence of xerophytic woodland with very low percentages of riparianforest and wet-prairie taxa. They cite high ratios of arboreal pollen to non-arboreal pollen as evidence of a relatively closed forest canopy (Walsh et al. 2010).

\section{History of Megafauna Research in the Willamette Valley}

For the past 100 years, researchers have noted the presence of bones from extinct mammals in the Willamette Valley (Connolly 2003a, 2003b; Hay 1927; McCornack 1914, 1920; Orr and Orr 1981; Orr and Orr 2009; Stenger 2002a). Early in Oregon's history, explorers, journalists, and pioneers noted finds of extinct mammals. During the United States' initial exploration and surveying of Oregon, bones of extinct animals were identified (Wilkes 1844:385) and discoveries of remains of extinct fauna apparently protruding from the cutbanks of rivers in the Willamette Valley were reported as early as the 1840s and 1860s (Oregon History Project 2010; Perkins 1842). The first record of an extinct, giant mylodont ground sloth anywhere in western North America was established in the Willamette Valley (Perkins 1842; Stock 1925:10). Paleontologists working in the early $20^{\text {th }}$ century noted the wealth of fossil material present (Hay 1927; McCornack 1914, 1920). Similarly, recent overviews of Oregon geology highlight the fossil material 
recovered from deposits in the Willamette Valley (Bishop 2003; Orr and Orr 1981; Orr and Orr 2009; Orr et al. 1992).

Despite this general knowledge, most Willamette Valley remains have never been described in detail or dated. Not since the early $20^{\text {th }}$ century have data concerning these fossils been systematically synthesized. McCornack (1914) and Hay (1927) catalogued the materials known to them in the 1910 s and 1920s. The researchers generally identified the species and skeletal element from a given locality, as well as provided approximate provenance and sometimes the history of the fossil's discovery. Over the following decades, peer reviewed articles occasionally mentioned finds of megafaunal remains in the Willamette Valley (Cressman 1947; Cressman and Laughlin 1941; Hansen and Packard 1949). Despite the apparent wealth of fossil material, the remains received limited scientific inquiry over the next half century.

In 1987, much public excitement was created by media coverage of paleontological finds at what is now known as Mammoth Park, in the city of Woodburn, Marion County (Barton et al. 2002). During installation of a sewer line, workers found large bones at depths of $5 \mathrm{~m}$, but the workers did not notify authorities and took the bones home with them (O’Connell 2002). As a result, there exists little documentation other than news reports and rumors of these discoveries. Nonetheless, the excitement over Mammoth Park served as a springboard for a series of inquiries over the last decade and a half.

Since the Mammoth Park finds, the Woodburn area has been the focus of numerous investigations by Alison Stenger working with amateur associations and school groups (Stenger 1996, 2000a, 2000b, 2001, 2002a, 2002b, 2003, 2004, 2005, 2006). 
Stenger's primary interest seems to be to locate evidence for late Pleistocene human occupation. These projects generally employ a backhoe to mechanically excavate sediments from the terminal Pleistocene strata known to exist in the area at depths of between 1-5 m. Volunteers then trowel through or screen the backhoe spoils in search of fossils or artifacts. These efforts have been successful at recovering faunal material and reportedly a wide range of mammalian taxa, as well as sparse quantities of possible archaeological materials (see discussion in following section).

Since the mid-1990s, an avocational group known as the Yamhill River Pleistocene Project has worked to identify, collect, and preserve fossils in and around the city of McMinnville in Yamhill County (Lysek 1999; Yamhill River Pleistocene Project 2010). Beyond simply collecting fossil bone material from erosional contexts, they have successfully identified intact paleontological deposits and have collaborated with professionals and other interested parties to conduct excavations to recover fossil material (Bonnichsen et al. 2002; Stenger 2010a; Stenger and Fitzsimons 2007). The Yamhill River Pleistocene Project continues to operate and consults regularly with current and former staff of the University of Oregon Museum of Natural and Cultural History (UO MNCH) (Yamhill River Pleistocene Project 2010).

Despite the recent interest and activity, megafaunal remains from only one locality have been documented in a peer reviewed publication (Barton and Cearley 2008), which reports the remains of a mammoth (Mammuthus columbi) initially discovered in 1967. Barton and Cearley's work included osteometric and stable isotope analyses and provided a calibrated age range of 14,050-13,730 cal BP (Wk-21807). 
In recent years, discoveries of megafauna in the Willamette Valley have continued to garner media attention (Bella 2007; Clampet 2006; Keefer 2010; Manzano 2007; Sherman 2006; The Times 2010). For example, finds of remains of extinct Pleistocene fauna received national attention in mainstream popular culture when two 10year old boys discovered a mammoth tooth in a ravine in Yamhill County (Manzano 2007). Their exploits netted the duo a trip to Hollywood and a seat alongside comedian Bill Cosby in an episode of "The Tonight Show with Jay Leno." Some discoveries of extinct fauna in the Willamette Valley have even been reported internationally (O'Connell 2002).

\section{Purported Human \& Megafauna Associations in the Willamette Valley}

Archaeological research in North America of the Paleoindian period has long focused on the causes and timing of the megafauna extinctions. Such studies have commonly considered the Paleoindians as specialized big game hunters pursuing their prey across vast ranges and environments of the continent (Haynes 2002; Kelly and Todd 1988; Waguespack and Surovell 2003). More recent work has offered different explanations of the subsistence strategies for Paleoindian peoples (Cannon and Meltzer 2004; Driskell and Walker 2007; Grayson and Meltzer 2002, 2003). This revision portrays Paleoindians as more generalized gatherers and hunters exploiting a broad spectrum of resources. Regardless, a recurring question across all of this research is the role humans played in the megafauna's demise.

Researchers working in the Willamette Valley have made claims of P/HT-aged artifacts in association with extinct fauna multiple times in Oregon archaeology's history 
(Cressman 1947; Cressman and Laughlin 1941; Stenger 2002a, 2010b). Despite these contentions, no firm association has linked human activity with extinct megafauna.

Cressman and Laughlin (1941) reported on a location in Linn County outside the town of Lebanon that they suggested showed an association between extinct fauna and human artifacts. The remains of a large animal were unearthed by a farmer while cleaning out his spring. Laughlin and a party of Willamette University professors later visited the site and recovered the remains of a mammoth and a possible bone chisel, both reported to have been situated in the same stratigraphic layer of blue clay. A possible stone artifact was also identified $1.12 \mathrm{~m}$ below the surface and situated "immediately by" one mammoth bone (Cressman and Laughlin 1941:341). This candidate for humanmegafauna association has been challenged on two counts. The objects in question could have been modified by natural agents and their stratigraphic link to the megafaunal remains is not convincing (White 1979).

Similarly, Cressman (1947) described a stemmed point discovered by a farmer in a drainage slough near Tangent in Linn County. The remains of a mammoth were also found in the same area. Cressman stated that he considered an association between the two not only possible, but probable. Despite this assertion, Cressman did not provide any evidence to support his claim. This makes it difficult to accept Cressman's case for human-megafaunal association (Connolly 1994).

As discussed previously, Stenger and colleagues have executed a series of backhoe investigations over the last decade and a half in the Mill Creek drainage in the city of Woodburn (Stenger 1996, 2000a, 2000b, 2001, 2002a, 2002b, 2003, 2004, 2005, 2006). These projects have focused on the recovery of fossil and artifactual material 
from the Terminal Pleistocene peat deposits deeply buried in Marion County. The Woodburn peat has yielded megafaunal remains as well as possible archaeological materials (Stenger 2002a, 2010). Evidence for human interaction with extinct fauna is reported to consist of possible culturally modified bison bones and antler tines. Other possible artifactual material recovered from the peat deposits includes lithic debitage and human hair.

The Woodburn materials have not been accepted as evidence of humanmegafaunal interactions for a variety of reasons. First, the investigations are conducted on deeply buried deposits $(\sim 1-5 \mathrm{~m})$ via backhoe. Excavation by backhoe is coarse by its very nature. In this process, it is not unusual for two, and sometimes as many as three, discrete stratigraphic layers to become intermixed (e.g., see Appendix 1 in Stenger 2003). Second, Stenger cites the peat bog deposits to be capped by a volcanic deposit whose origin is the Mt. Mazama eruption at 7,700 cal BP (Stenger 2010b). Based on Stenger's interpretation, it seems that any cultural materials recovered from the peat bog could have been deposited into the matrix at anytime from the formation of the bogs following the cessation of the Missoula Floods ( 15,000 cal BP) to their eventual envelopment by Mazama pyroclastic airfall, a period of over 7,000 years. Third, none of the potential archaeological materials has ever been analyzed and reported by a professional archaeologist. Lastly, the Woodburn findings are insufficiently documented to evaluate. Evidence of human modification of bone is noted but is not critically examined. Connolly (2003a, b) writes that while the material recovered from the Woodburn bogs is intriguing, the evidence for human involvement is equivocal. 
Stenger (2010b) has reissued claims of a possible association between terminal Pleistocene foraging groups and extinct fauna, in a local archaeology newsletter that is not peer reviewed. It suggested the identification of four pre-Clovis archaeological "site areas" in the Willamette Valley. These "site areas" are described as consisting of flaked stone and culturally modified remains of extinct animals.

The above claims regarding evidence for pre-Clovis in the Willamette Valley need to be further studied. None of the deposits constitute an intact archaeological site. While some of the lithic materials appear cultural in origin, they lack stratigraphic context. For example, some of the materials were recovered in erosional contexts such as the bed of an active river channel. In other occurrences, cultural materials were admittedly found in disturbed contexts that included modern bottle glass. In addition, the identification of culturally modified megafaunal remains is difficult in the best of circumstances (Lyman 1994), given multiple agents that can leave similar traces. As with many other claims of an association between humans and extinct fauna elsewhere in North America (Grayson and Meltzer 2002), the evidence is equivocal. 


\section{CHAPTER 3: EXPECTATIONS}

This section sets forth a series of research questions, hypotheses, and expectations that are investigated through my study (Table 3.1). Some of the research questions are presented as formal hypothesis that are tested. Other questions are more exploratory and are addressed through comparing and contrasting my results with previously known archaeological and paleoenvironmental data.

\section{What is the origin/source of the paleontological remains?}

$\mathrm{H}_{1}$ : The terminal Pleistocene fauna are autochthonous to the Willamette Valley.

$\mathrm{H}_{\mathrm{OA}}$ : The terminal Pleistocene fauna are not autochthonous to the Willamette Valley.

They are allochthonous, possibly isolated skeletal elements transported in Missoula Flood sediment loads.

$\mathrm{H}_{\mathrm{oB}}$ : The terminal Pleistocene fauna are not autochthonous to the Willamette Valley.

They are allochthonous, possibly carcasses ice rafted by the Missoula Floods.

If $\mathrm{H}_{1}$ :

- I expect that the radiocarbon dates would post-date the last of the Missoula Floods $(<\sim 15,000$ cal BP $)$.

- I expect that the geologic context of each paleontological locality would indicate a post-flood origin (would be superimposed over Missoula Flood sediments or other earlier Pleistocene sediments).

- I expect the bones will not show evidence of stream rolling, impact fractures, or fluvial abrasion. 
Table 3.1. Summary of Research Questions and Hypotheses

I What is the origin/source of the paleontological remains?

$\mathrm{H}_{1}$ : The terminal Pleistocene fauna are autochthonous to the Willamette Valley.

$\mathrm{H}_{\mathrm{oA}}$ : The terminal Pleistocene fauna are not autochthonous to the Willamette Valley. They are allochthonous, possibly isolated skeletal elements transported in Missoula Flood sediment loads.

$\mathrm{H}_{\mathrm{oB}}$ : The terminal Pleistocene fauna are not autochthonous to the Willamette Valley. They are allochthonous, possibly carcasses ice rafted by the Missoula Floods.

II Was the loss of local megafauna related to climate cooling of the YD Stadial?

$\mathrm{H}_{1}$ : The onset of the YD caused a decline/loss of megafauna at the YD threshold $(12,900 \mathrm{cal}$ BP).

$\mathrm{H}_{\mathrm{o}}$ : The YD did not cause a decline/loss of megafauna at the YD threshold (12,900 cal BP).

IV What was the general character of Willamette Valley late Pleistocene environments?

$\mathrm{H}_{1:}$ In the late Pleistocene, the Willamette Valley ecosystem was an open environment (i.e., it was not a closed canopy forest).

$\mathrm{H}_{\mathrm{o}}$ : In the late Pleistocene, the Willamette Valley ecosystem was not an open environment (i.e., it was a closed canopy forest).

$\mathrm{H}_{1}$ : In the late Pleistocene, Willamette Valley megafauna consumed warm weather $\mathrm{C}_{4}$ grasses. $\mathrm{H}_{\mathrm{o}}$ : In the late Pleistocene, Willamette Valley megafauna did not consume warm weather $\mathrm{C}_{4}$ grasses (i.e., they consumed predominantly $\mathrm{C}_{3}$ plants).

$\mathrm{V}$ What is the relationship between fossil age and the record for late Pleistocene vegetation change in the region?

VI What is the relationship between fossil age and the known timing of human occupation in the Pacific Northwest? 
- I expect some of the fossil material to be articulated skeletons/skeletal elements rather than isolated bones.

If $\mathrm{H}_{\mathrm{OA}}$ :

- I expect that the radiocarbon dates would pre-date or at least be contemporaneous with the last of the Missoula Floods ( $\geq 15,000$ cal BP).

- I expect that the faunal remains will be found in Missoula Flood sediments or other earlier Pleistocene events.

- I expect the bones to show fractures and/or abrasive striations or be found as isolated specimens if transported by a high energy fluvial event (Missoula Floods). If $\mathrm{H}_{\mathrm{oB}}$ :

- I expect that the radiocarbon dates would pre-date or at least be contemporaneous with the last of the Missoula Floods ( $\geq 15,000 \mathrm{cal} \mathrm{BP})$.

- I expect that the faunal remains will be found in Missoula Flood sediments or other earlier Pleistocene events.

- Given the habitat and dietary preferences of the considered megafaunal genera (see Chapter 5 and Table 5.3), it is unlikely that these fauna would inhabit the fringes of the continental ice sheets. As such, it is unlikely there would be opportunity for carcasses to become encased in ice and rafted in to the valley. Likewise, it is unlikely that carcasses could remain intact after first enduring glacial entrapment, then the physical stresses imposed during transport and deposition by Missoula Flood waters, followed by post-Missoula Flood hydrologic adjustment by the Willamette River and its tributaries. A possible test of this hypothesis though, would examine the spatial relationship between glacial erratics and paleontological 
localities. One would expect erratics and carcasses to co-vary in distribution given a common source.

\section{Was the loss of local megafauna related to climate cooling of the YD Stadial?}

$\mathrm{H}_{1}$ : The onset of the YD caused a decline/loss of megafauna at the YD threshold $(12,900$ cal BP).

$\mathrm{H}_{\mathrm{o}}$ : The YD did not cause a decline/loss of megafauna at the YD threshold $(12,900 \mathrm{cal}$ $\mathrm{BP})$.

If $\mathrm{H}_{1}$ :

- I would expect bone samples would not date after the inception of the YD (all radiocarbon dates would be $\geq 12,900$ cal $\mathrm{BP}$ ).

If $\mathrm{H}_{0}$ :

- I would expect the dated bone samples to persist past the YD threshold (some radiocarbon dates would be $<12,900 \mathrm{cal} \mathrm{BP}$ ).

What was the general character of Willamette Valley late Pleistocene environments?

$\mathrm{H}_{1}$ : In the late Pleistocene, the Willamette Valley ecosystem was an open environment (i.e., it was not a closed canopy forest).

$\mathrm{H}_{\mathrm{o}}$ : In the late Pleistocene, the Willamette Valley ecosystem was not an open environment (i.e., it was a closed canopy forest).

If $\mathrm{H}_{1}$ :

- I would expect more enriched stable carbon isotopic values ( >-23\%).

- I would expect the large mammal community to be composed of taxa inferred to be more adapted to a grass based diet and associated with open landscapes. 
If $\mathrm{H}_{\mathrm{o}}$ :

- I would expect more depleted stable carbon isotopic $\left(\delta^{13} \mathrm{C}\right)$ values indicating a canopy effect. Based on Bocherens' (2003) and van der Merwe and Medina’s (1991) study of arctic, temperate and steppe areas, the canopy effect would be characterized by greater depletion of $\delta^{13} \mathrm{C}$ values ( $<-23 \%$ to $-27 \%$ ) as compared to open environments.

- I would expect the large mammal community to be composed of browsing taxa more adapted to a closed (forest) environment.

$\mathrm{H}_{1}$ : In the late Pleistocene, Willamette Valley megafauna consumed warm weather $\mathrm{C}_{4}$ grasses.

$\mathrm{H}_{\mathrm{o}}$ : In the late Pleistocene, Willamette Valley megafauna did not consume warm weather $\mathrm{C}_{4}$ grasses (i.e., they consumed predominantly $\mathrm{C}_{3}$ plants).

If $\mathrm{H}_{1}$ :

- I would expect the bone collagen stable carbon isotopic $\left(\delta^{13} \mathrm{C}\right)$ values of herbivores to be approximately $-7.5 \%$.

If $\mathrm{H}_{\mathrm{o}}$ :

- I would expect the bone collagen stable carbon isotopic $\left(\delta^{13} \mathrm{C}\right)$ values of herbivores to be approximately $-21.5 \%$.

\section{What is the relationship between fossil age and the record for late Pleistocene} vegetation change in the region?

There are no paleoenvironmental studies conducted on the floor of the Willamette Valley that encompass the late Pleistocene. The nearest paleoecological reconstruction 
was conducted at Battle Ground Lake, Washington (Barnosky 1985; Walsh et al. 2008).

The ages of the fauna in this study will be arrayed against the timing of environmental change as recorded at Battle Ground Lake.

\section{What is the relationship between fossil age and the known timing of human occupation in the Pacific Northwest?}

There are no known archaeological sites that date to the late Pleistocene in the Willamette Valley. As such, it is not possible to test specific hypotheses regarding the nature of Paleoindian economy or the nature of any interaction late Pleistocene peoples had with extinct fauna in the region. Regardless, cultural materials of Pleistocene age are known in the Willamette Valley but generally consist of finds of isolated, temporally diagnostic projectile points associated with Paleoindian or paleo-archaic archaeological cultures. These materials point towards a faint, yet widespread Paleoindian presence in western Oregon in the late Pleistocene (Ozbun et al. 1997). As such, it is appropriate to explore the relationship of the timing of the ages of the megafauna in this study with the timing of the earliest known human occupation of the Pacific Northwest and in Oregon [14,270 cal BP at Paisley Caves (Gilbert et al. 2008)] and with the timing of the Clovis Paleoindian Horizon [14,250-12,800 cal BP (Waters and Stafford 2007)]. These data will establish a baseline for future Paleoindian, paleoenvironmental, and extinction studies in the Willamette Valley. 


\section{CHAPTER 4: METHODS AND MATERIALS}

\section{Archival and Public Research}

While the Willamette Valley has long been noted for discoveries of extinct Pleistocene faunal remains, this information has not been synthesized since the $1920 \mathrm{~s}$ (Hay 1927). As such, the goal of the first phase of archival research was to synthesize all known records of extinct mammalian herbivores reported within the confines of the Willamette Valley. Archival research for this study included the review of published and unpublished archaeological, paleontological, historical, and geological reports, as well as scholarly articles and books. Conversations with state and federal archaeologists and paleontologists, cultural resource management archaeologists, university professors of anthropology and the geological sciences, and museum curators helped guide my efforts.

Considerable time was spent reviewing the computer database and paper records of the mammalian fossil materials curated in the paleontological collections of the UO $\mathrm{MNCH}$. Additional time was spent in interviews with the current fossil collections manager of the UO MNCH (Dr. Edward Byrd Davis), as well as with former curators, directors, and staff (Dr. William Orr, Dr. Laurence Kittleman, and Mrs. Elizabeth Orr). In some instances, paperwork documenting some specimens now housed at UO MNCH was not found. In these instances, I attempted to contact the original researcher/s involved in the recovery and/or curation of these materials. I photocopied records for my study and furnished copies to the UO MNCH. After review of the literature and UO $\mathrm{MNCH}$ records, I physically went through the vertebrate paleontological collections at the $\mathrm{UO} \mathrm{MNCH}$ and attempted to relocate the specimens noted in the various papers and reports. 
This project was begun with the understanding that an unknown number of additional specimens of extinct fauna might exist in private collections. Internet searches identified a suite of entities, such as county museums, historical societies, and even private citizens who potentially possessed fossil collections, or may have knowledge of paleontological localities of extinct mammalian fauna. I contacted various individuals and organizations and set up interviews and meetings to learn more about collections and to gain permission to sample specimens from these private collections. I also suggested individuals donate collections to $\mathrm{UO} \mathrm{MNCH}$ in order to safeguard the fossils in the long term.

\section{Sample Selection}

For my study, I employ the use of paleozoological terminology as set forth by Lyman (2008:4-7, 57-66). An "individual" is defined as a single animal. Following Lyman, a "skeletal element" is a complete, discrete anatomical unit, such as a bone or tooth. Meanwhile, a "specimen" is defined as any isolated bone or tooth, whether anatomically complete or not. For example, every complete mammoth humerus is a skeletal element, as well as a specimen. However, if only the distal most portion of the mammoth humerus is present, then it qualifies as a specimen, but not a skeletal element. Next, the portion of the element present is referred to as the "skeletal part." In our previous example, the skeletal part present would be the distal humerus.

Following the archival research portion of this project, specimens were selected for specialized analyses, including for radiocarbon and stable isotope analysis. My original goal was to select remains from 15-20 individuals. During the formative stages of this thesis, it was debated whether there should be an emphasis to study a particular 
taxon or a variety of taxa. For example, the initial literature review led me to believe that this project would uncover a large number of mammoth remains. If that was the case, would this study serve better to develop a robust chronology for a single genus rather than a broader study of several? In the end, this was not a consideration.

The selection of specimens for specialized analysis was based upon four attributes. First, faunal specimens were selected that possessed the best information regarding geologic context. Second was preservation. I used Behrensmeyer's (1978) qualitative scale of weathering, choosing specimens scoring 0,1 ,or 2 , which were most likely to possess enough collagen to radiocarbon date. For example, some fossil material appeared grayish-white and splintered from gentle touch. Such a specimen had been affected by biostratinomic and/or diagenetic stress and appeared unlikely to yield enough collagen for radiocarbon and stable isotope analysis. The third criterion was accuracy and precision of taxonomic identifications. Was enough of the specimen present to allow for an accurate generic or sub-generic taxonomic identification? I focused on the most readily identifiable specimens. Lastly, as the project includes destructive analyses, the fossil collections manager at $\mathrm{UO} \mathrm{MNCH}$ only authorized sampling if loss did not much reduce future research value. Every effort was made to select a single skeletal element from an individual creature. This was possible except for the Woodburn-Legion Park specimens.

\section{Taxonomic Identifications}

I attempted to identify each specimen examined to the finest taxon possible. Each specimen had previously been assigned taxonomic identifications to at least the level of genus. Often only minimal documentation about morphological criteria used for 
taxonomic identifications was available. Thus, all prior identifications were considered tentative and I attempted to increase confidence in the identifications by re-establishing taxonomic identifications. This was accomplished through conferring with vertebrate paleontologists (including sharing photographs and metrics) and comparative analysis with specimens at the UO MNCH and with published scientific articles or manuscripts that address diagnostic osteological features of these animals, or some combination of the above. Specimens included in the specialized analyses were identifiable to at least genus. Appendix $\mathrm{C}$ describes procedures used to make assignments.

\section{Documentation of Paleontological Localities and Specimens}

Minimal documentation existed for most of the specimens included in this study. One of my goals was to create as detailed a record as possible for each fossil. I recorded the geographic location and geologic context of each locality, the history of recovery of fossil material from each locality, and a description of the fossil/s. The description of the bone specimens included an account of their general condition, taphonomic observations, and the diagnostic criteria upon which taxonomic designations were based. Each skeletal element was photographed. A standard set of morphological characters was measured (e.g., von den Driesch 1976).

In order to test the hypothesis that animal remains represent carcasses that were

rafted in by Missoula Flood ice floes, I examined the spatial relationship between glacial erratics and paleontological localities. O’Connor (Jim E. O’Connor, personal communication 2011) suggests that ice rafts were small and that erratics and carcasses would be relatively close together if they represented the same agent of deposition. In ArcGIS 9.3, I visually selected a point approximately at the center of each of 
paleontological locality. Locations of glacial erratics were drawn from Minervini et al. (2003), whose shapefile and geodatabase are available for download from the U.S. Geological Survey (USGS) website (http://pubs.usgs.gov/of/2003/of03-408/). ArcGIS Spatial Analyst was then employed to calculate the distance from each paleontological locality to the nearest glacial erratic.

Documentation of the paleontological localities and specimens is presented in attached appendices. The description of the paleontological localities is presented in Appendix B. Descriptions of the fossil materials are in Appendix C. Appendix D consists of photo-documentation of each specimen. Appendix E contains osteometric measurements of each bone. Appendix F is a series of illustrations adapted from published osteological guides indicating the locations of each of the measurements shown in Appendix E.

\section{AMS Radiocarbon Dating}

In total, 15 bone specimens are considered in the specialized analyses of this study. Fourteen bone specimens were sampled for AMS radiocarbon dating. Nine of these specimens clearly represented distinct individual animals. The other five specimens were recovered from the Woodburn-Legion Park area. Given the coarse methods by which these fossils were recovered, it is not possible to know with certainty whether each of these five specimens represents an individual creature. At minimum, these five specimens represent three individuals. A fifteenth specimen, representing a single individual, is included in this thesis but was not radiometrically dated due to the degraded state of bone collagen. That specimen is discussed more fully below. 
Most bone specimens submitted for radiometric analysis were dated multiple times, at different laboratories, using different pretreatment methods. This provided an opportunity to examine the effects of different pretreatment methods on radiocarbon measurements, as well as an opportunity to compare the precision and accuracy of determinations from different radiocarbon laboratories. Specimens were submitted to laboratories in three different batches as the thesis project developed and more specimens became available.

The first batch consisted of 12 samples analyzed by the NSF-Arizona AMS Laboratory (the Arizona Lab). The 12 samples consisted of 11 different bone specimens. As a test for replicability, a sample from a single specimen (UO MNCH \#F-42801, the Woodburn High School Bison) was submitted to the lab as two separate samples (AA87430/u and AA87431/u).

Following demineralization, gelatinization, and collagen extraction of each of the 12 samples at the Arizona Lab, the final collagen product was subjected to two different filtration methods. The Arizona Lab first subjected all the samples to their standard filtration process, which consists of injection through an Autovial $0.45 \mu \mathrm{m}$ glass microfiber filter. After completion of the standard filtration process, approximately half of the collagen from each sample was subjected to a further filtration process, ultrafiltration.

The method of ultrafiltration was originally outlined by Brown et al. (1988). By use of a centrifuge, ultrafiltration acts to remove exogenous carbon by separating high molecular weight constituents of the gelatinized collagen from low molecular weight components such as degraded collagen fragments, contaminating acids, and other 
potential contaminants. Studies have shown the ultrafiltration method to be successful at improving the quality of gelatinized collagen by the removal of contaminants that can lead to erroneous radiocarbon measurements (Higham et al. 2006).

To examine the effects of ultrafiltration on radiometric results, each of the 12 samples (representing 11 different bone specimens) submitted to the Arizona Lab were split into two portions, one set processed using standard filtration processes and the other portion through ultrafiltration. The split samples were then each submitted for AMS dating, for a total of 24 AMS measurements from the Arizona Lab.

As my thesis research developed, I learned of additional approaches with AMS dating of bone being developed by Doug Kennett and his colleagues at the Archaeometry Facility of the Department of Anthropology at the University of Oregon (the Archaeometry Facility) and the Keck Carbon Cycle AMS Facility at the University of California, Irvine (UCI). The Archaeometry Facility and UCI employ different protocols (especially XAD-purification) than the Arizona Lab, which are suggested to increase confidence in the fidelity of the biogenic signal, as well as higher precision AMS dates than are possible at other radiocarbon labs (Culleton 2011; Kennett et al. 2011).

The XAD-purification technique was developed and refined by Stafford et al. $(1988,1991)$. Humates are the primary sources of contamination in the analysis of the radiocarbon molecule and stable isotopes used in the analysis of fossil bone. XAD (styrene-divinylbenzene) is a porous, highly adsorbent resin capable of isolating particular molecules. In the XAD-purification process, hydrolyzed collagen is passed through a columnar tube packed with XAD resin. The resin bed disassociates potentially contaminating humic and fulvic acids bound to the collagen and the purified product 
(amino acids derived from the collagen) passes through the resin into a reservoir. A key advantage to this technique is its ability to eliminate contaminating foreign carbon (such as humates) from bone collagen samples. Specifics on the XAD process as practiced by the Archaeometry Facility are detailed by Culleton (2011). See Appendix H for specifics.

The "collagen yield" resulting from any pretreatment method is actually a vaguely defined category in the literature as different end products result from different pretreatment methods (e.g., ultrafiltration vs. XAD). The end product of each method is actually a different component of the collagen macromolecule. To be specific, the end product on which later measurements are based (whether AMS or stable isotope) in the XAD-purification process is amino acids.

Each of the 11 specimens submitted to the Arizona Lab was re-sampled by the Archaeometry Facility for pretreatment through XAD-purification. Three additional bone specimens I learned of after the Arizona Lab work were also included in the XADpurification. Upon completion of pretreatment, XAD filtering, and other procedures at the Archaeometry Facility, the 14 samples were submitted for AMS radiocarbon dating to UCI.

In my results, I also consider an additional individual, the PratumRutschman/Qualey Mammoth (the PRQ Mammoth), previously analyzed (AMS radiocarbon and stable isotopes) at the Waikato Radiocarbon Dating Laboratory (the Waikato Lab), using ultrafiltered dentine extracted from a molar (Barton and Cearley 2008; Cearley 2008). I submitted a sample of dentine from the PRQ Mammoth to the Achaeometry Facility for radiometric analysis, but it failed to yield sufficient collagen. 
As such, I default to the data previously reported (Barton and Cearley 2008; Cearley 2008). This brings the total number of specimens which I review in this study to 15 bone specimens from at least 13 separate animals.

Radiocarbon ages were calibrated using the OxCal v4.1 radiocarbon calibration program (Bronk Ramsey 2010), using the IntCal09 atmospheric data from Reimer et al. (2009). All radiocarbon ages are presented in calibrated calendar years before present (cal BP), where present is 1950 A.D.

\section{Stable Isotope Analyses}

A split sample of each bone specimen was submitted by the Archaeometry Facility to the UCI stable isotope unit for analysis of stable carbon $\left(\delta^{13} \mathrm{C}\right)$ and nitrogen $\left(\delta^{15} \mathrm{~N}\right)$ isotopes. Stable isotope samples were analyzed on a Fisons NA1500NC elemental analyzer and Finnigan Delta Plus isotope ratio mass spectrometer. The samples were measured with a precision of $<0.1 \%$ on aliquots of XAD-treated gelatin for both $\delta^{13} \mathrm{C}$ and $\delta^{15} \mathrm{~N}$. All isotopic ratios are expressed in standard delta notation, where:

$\delta^{\mathrm{E}} \mathrm{X}=\left(\mathrm{R}_{\text {sample }} / \mathrm{R}_{\text {standard }}-1\right) 1000$ where ${ }^{\mathrm{E}} \mathrm{X}$ is either ${ }^{13} \mathrm{C}$ or ${ }^{15} \mathrm{~N}$ and $\mathrm{R}_{\text {sample }} / \mathrm{R}_{\text {standard }}$ is either ${ }^{13} \mathrm{C} /{ }^{12} \mathrm{C}$ or ${ }^{15} \mathrm{~N} /{ }^{14} \mathrm{~N}$. The standard is the marine carbonate V-PDB for $\delta^{13} \mathrm{C}$ and atmospheric nitrogen (AIR) for $\delta^{15} \mathrm{~N}$.

As with the radiocarbon measurements, I include the stable isotopic data reported for the PRQ Mammoth (Barton and Cearley 2008; Cearley 2008). When Barton and Cearley (2008) submitted their samples for analysis, the Waikato Lab prepared all samples in their lab and stable isotopes were then measured at the Agriculture and Life Sciences Division at Lincoln University in New Zealand (Fiona Petchey, personal communication 2011). Isotopic measurements were measured on a PDZ Europa 
elemental analyser (GSL) connected to a continuous flow stable isotope mass spectrometer (20-20). The samples were measured on gelatin with a precision of $0.1 \%$ o for $\delta^{13} \mathrm{C}$ and $0.2 \%$ for $\delta^{15} \mathrm{~N}$.

\section{Bone Collagen Preservation}

Bone has long been recognized as being susceptible to degradation (diagenetic alteration/breakdown) and contamination (presence of exogenous contaminants) (Stafford

et al. 1988; Taylor 1992; van Klinken 1999). A series of procedures developed to test the state of preservation of bones utilized for isotopic analysis outlined in Chapter 2 were followed in this study. 


\section{CHAPTER 5: RESULTS}

\section{Archival and Public Research Results}

Archival and public research tracked a substantial number of reported finds of megafauna in the Willamette Valley. Unfortunately, a majority of the megafauna remains unearthed over the last century and half could not be relocated. Meanwhile, a variety of specimens recovered in more recent decades were identified. This section outlines the results of this inventory.

Table 5.1 summarizes all reported finds of extinct mammalian herbivores in the Willamette Valley sorted by county and taxon. The data is reported by number of reported finds, not number of specimens, skeletal elements, or individuals. For example, if the literature noted the find of multiple bison bones (elements often not specified) at a single locality, this was tallied as a single find of Bison sp. Furthermore, if a document noted the find of one mammoth bone and one bison bone, this was recorded as two finds, one of each taxon. This method provided a crude way to monitor the frequency of finds of any taxon given the often minimal information reported in the literature. Table 5.1 includes only those fauna that have been reported in either a published article or an unpublished manuscript. Finds of megafauna noted by media outlets or private websites are not included. Appendix A provides a more comprehensive synthesis of these finds that includes more data on the skeletal elements represented, provenance of each specimen, bibliographic references, and catalogue numbers if available. Both Table 5.1 and Appendix A are surveys of the available literature but no conclusions on the abundance of any taxa is attempted as most claims are not verified. 


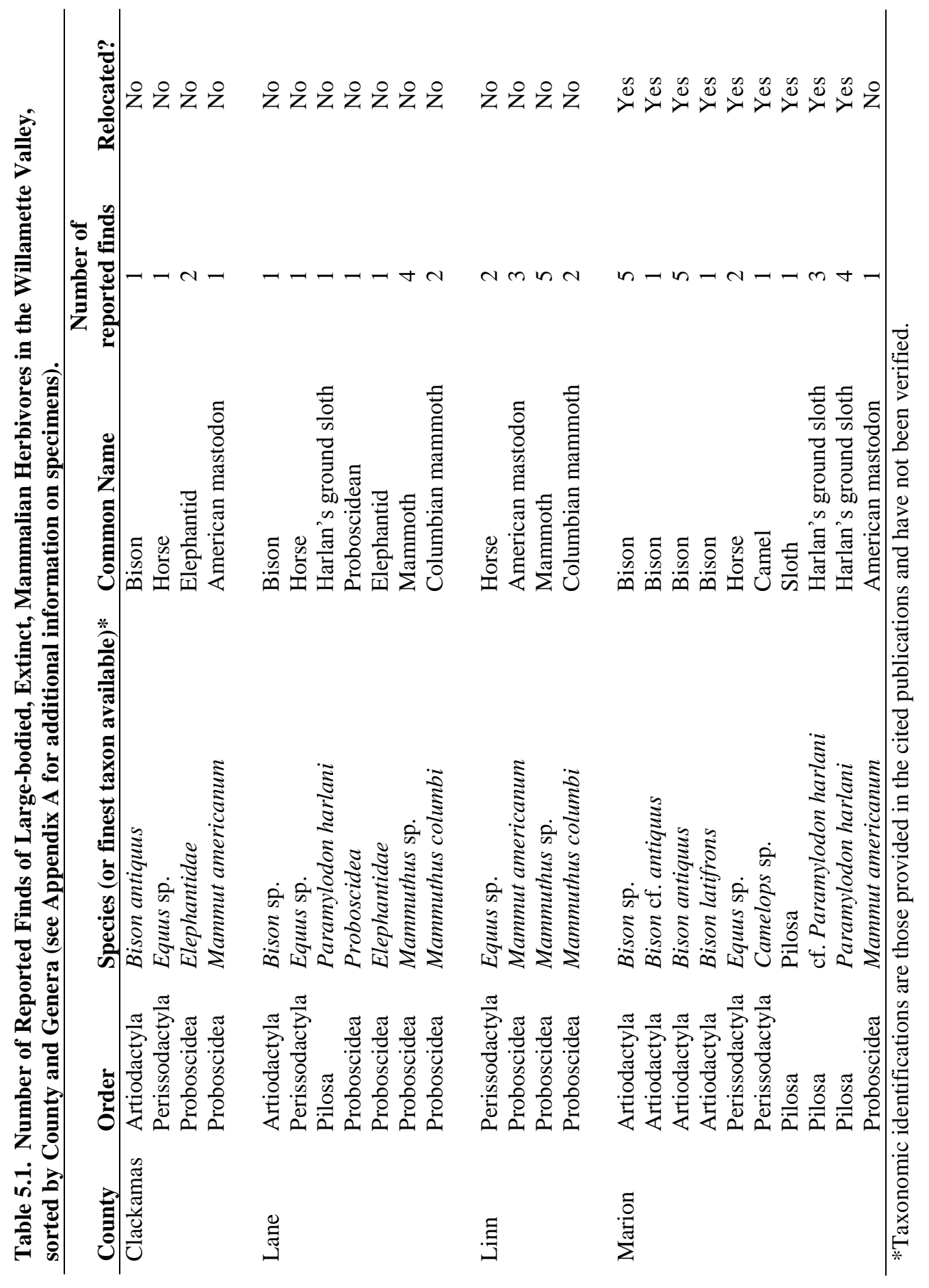




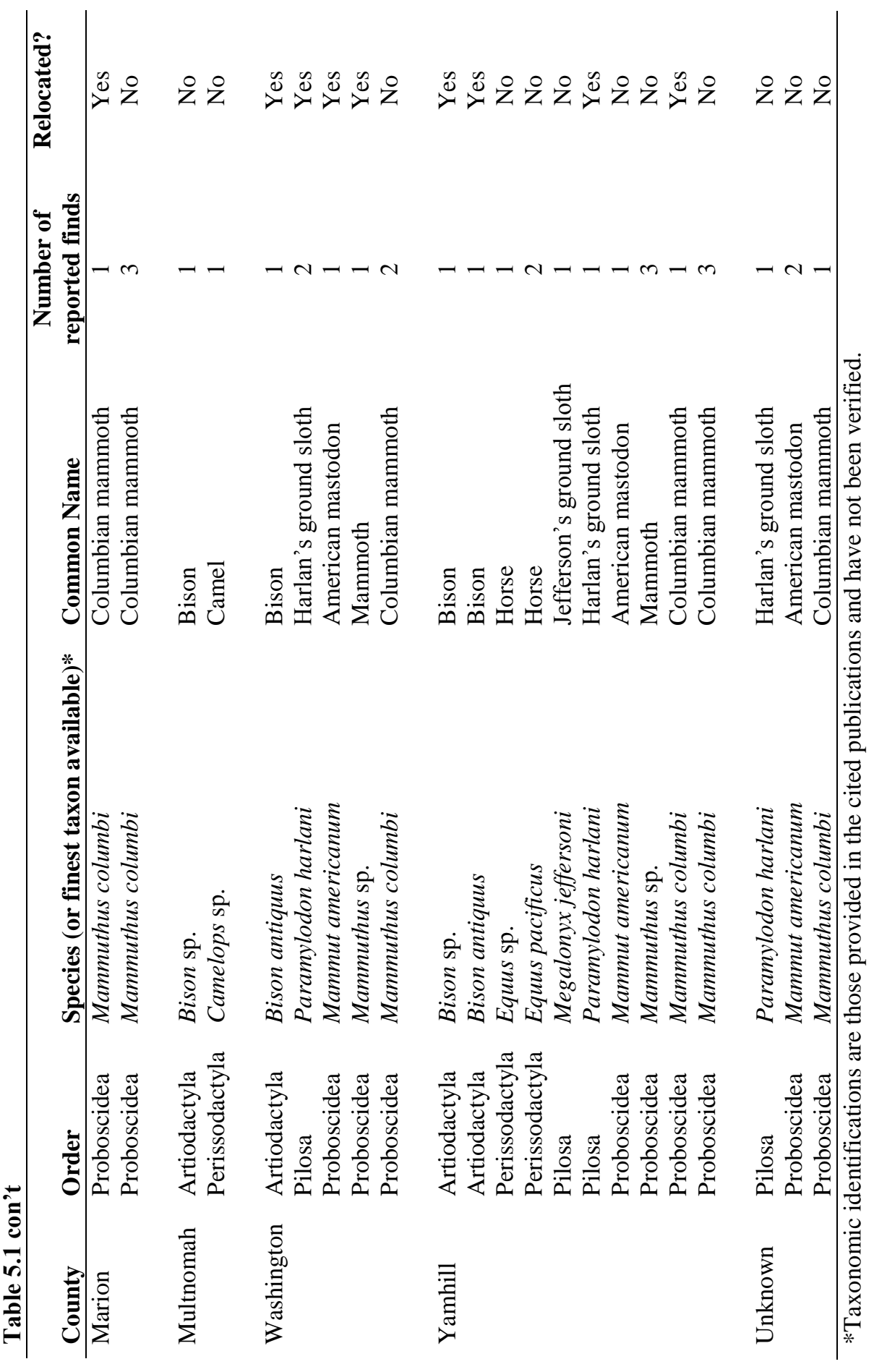


The literature review supports the conception of the richness of the Pleistocene fossil record in the Willamette Valley. While mention of the Willamette Valley in professional literature has been absent over most of the last century, this appears to be a result of a lack of professional focus on western Oregon rather than a lack of fossil material. While a few researchers studied Willamette Valley megafauna in the early $20^{\text {th }}$ century (Condon 1902; Hay 1927; McCornack 1914), the subject was largely ignored by professionals, aside from a few exceptions (Cressman 1947; Cressman and Laughlin 1941; Hansen and Packard 1949), from 1927 until the early- to mid-1990s. While the scientific community has remained largely ignorant of the research potential in the valley, the literature review attests to the relative richness of fossil material from the late Pleistocene. Unfortunately, many of these materials are likely lost to science.

The literature contained 87 instances of reported finds of megafauna. The fossil material from 54 of these finds, or $62 \%$, could not be relocated. The fossil material from only 33 of those finds (38\%) could be relocated. This material is either curated at the UO $\mathrm{MNCH}$ or is owned by private organizations that are developing relationships with the UO MNCH for long-term curation (see Chapter 6).

None of the specimens noted in the $19^{\text {th }}$ or early $20^{\text {th }}$ century (Hay 1927; McCornack 1914) could be relocated. Their exact fate is unknown. As many fossils were in private collections, their loss is not surprising; given that original ownership was not known, there was no way to track down the fossils. Curiously, some of the missing material had been curated at the UO MNCH. These losses are perhaps explained by shifting priorities including funding cuts that eliminated the professional staff in the 1970s, a situation not rectified until recent years. The paleontological collections did not 
receive institutional support for an extended time. Instead, they were maintained by volunteers for most of the last four decades. As such, it is to be expected that there are irregularities in the records and insufficient documentation for some material.

A variety of fossils recovered in more recent decades were identified in the collections at the UO MNCH. These consist of the materials recovered in more recent decades, such as the previously discussed Woodburn backhoe expeditions that have occurred over the last 15 years. These remains have not been systematically catalogued and analyzed. These fossil materials are curated at the UO MNCH and are available for future research.

I became aware of other privately held megafauna fossils during public outreach, some of which were later included in my specialized analyses. Some of these have already been accessioned into the $\mathrm{UO} \mathrm{MNCH}$, while others are in the process.

Presumably, they will all eventually be available for future research. Meanwhile, I continue to work to develop good faith relationships with other individuals in the Willamette Valley that possess fossil collections.

\section{Description of Specimens/Localities in Specialized Analyses}

Fifteen specimens from nine paleontological localities were included in the radiometric and stable isotope study. The fifteen specimens represent five genera (Figure 5.1, Table 5.2). The most represented genera is Bison, which includes six specimens. There are three specimens of both Mammuthus (mammoths) and Paramylodon (Harlan's ground sloth). Two horse (Equus) specimens and a single mastodon (Mammut) are also included. Each specimen and paleontological locality is documented more fully in Appendices B through F. 


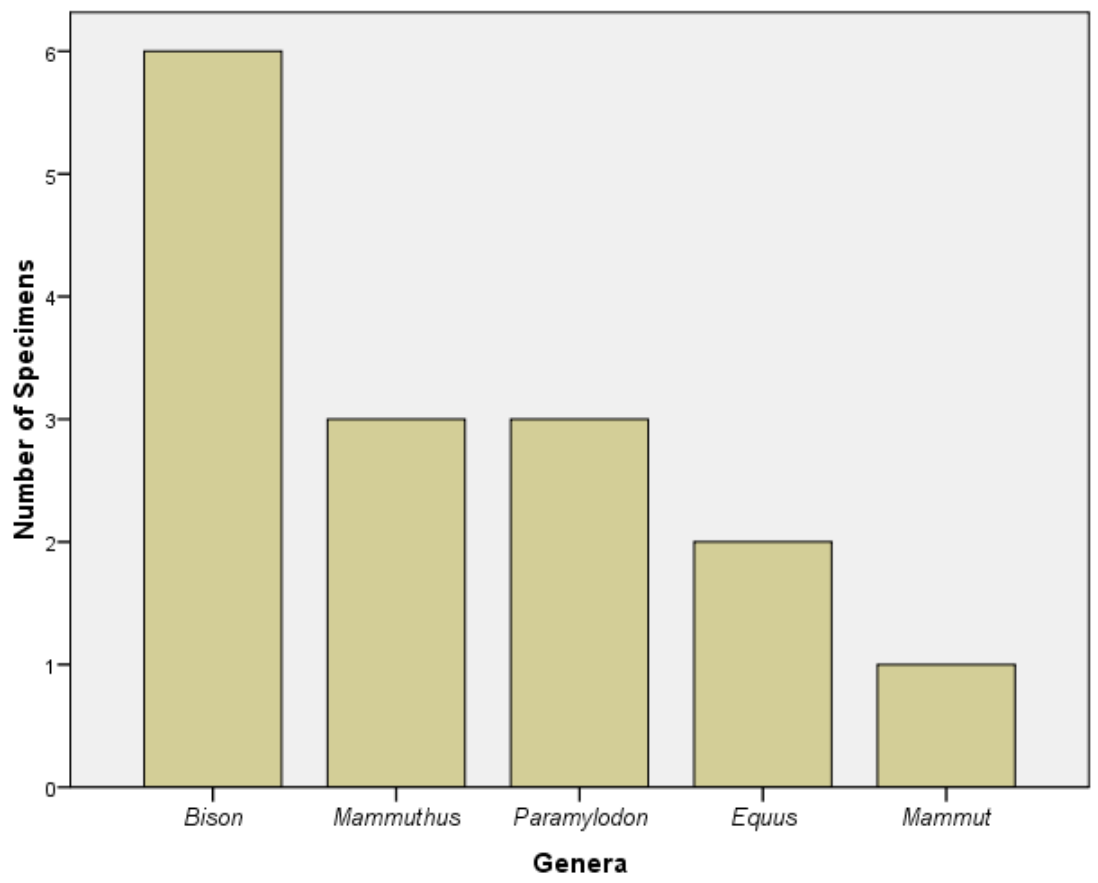

Figure 5.1. Number of Specimens from each Genera Represented in this Study

Every effort was made to select for analyses a single skeletal element from an individual creature. This was possible except for the Woodburn-Legion Park specimens, which as noted previously, represent at least three individuals. The Woodburn-Legion Park fauna were recovered from a deeply buried late Pleistocene bog by backhoe. The area of the bog that was investigated measured approximately $25 \mathrm{~m} \mathrm{x} 15 \mathrm{~m}$ (Stenger 2006:9). Skeletal elements are distributed across the landform. As such, it is not possible to determine if two specimens are derived from a single individual. I interpret the five Woodburn-Legion Park fauna to represent at least three individuals. I base this on two factors. First, the five specimens represent two separate genera, Bison and Equus. As such, there are at least two individual creatures represented. Second, the radiometric measurements indicate that one of the Bison specimens (UO MNCH \# F-38522, UCIAMS78130) is approximately 1,000 years younger than the other two bovids from 
Woodburn-Legion Park, indicating that at least two bison are present. As such, I

interpret the 15 specimens to represent at least 13 individual animals.

Table 5.2. List of Fossil Material included in Radiometric/Stable Isotope Study

\begin{tabular}{|c|c|c|c|c|}
\hline Locality & Genus/Species & $\begin{array}{l}\text { Common } \\
\text { name }\end{array}$ & $\begin{array}{l}\text { UO MNCH } \\
\text { designation }\end{array}$ & $\begin{array}{l}\text { Skeletal } \\
\text { element } \\
\text { sampled }\end{array}$ \\
\hline Hillsboro & $\begin{array}{l}\text { Mammuthus sp. } \\
\text { Paramylodon } \\
\text { harlani } \\
\text { Bison antiquus }\end{array}$ & $\begin{array}{l}\text { Mammoth } \\
\text { Harlan's } \\
\text { ground sloth } \\
\text { Bison }\end{array}$ & $\begin{array}{l}\text { F-29247 } \\
\text { F-29242 } \\
\text { F-29240 }\end{array}$ & $\begin{array}{l}\text { Rib } \\
\text { Right femur } \\
\text { Cranium }\end{array}$ \\
\hline Tualatin & $\begin{array}{l}\text { Mammut } \\
\text { americanum }\end{array}$ & $\begin{array}{l}\text { American } \\
\text { Mastodon }\end{array}$ & F-30282 & Pelvis \\
\hline $\begin{array}{l}\text { Tualatin River- } \\
\text { Fanno Creek }\end{array}$ & $\begin{array}{l}\text { Paramylodon } \\
\text { harlani }\end{array}$ & $\begin{array}{l}\text { Harlan's } \\
\text { ground sloth }\end{array}$ & pending & Synsacrum \\
\hline $\begin{array}{l}\text { Woodburn High } \\
\text { School }\end{array}$ & Bison antiquus & Bison & F-42801 & Rib \\
\hline $\begin{array}{l}\text { Woodburn- } \\
\text { Legion }\end{array}$ & Equus sp. & Horse & F-37000 & $3^{\text {rd }}$ phalanx \\
\hline Park & $\begin{array}{l}\text { Equus sp. } \\
\text { Bison } \mathrm{sp} . \\
\text { Bison } \mathrm{sp} . \\
\text { Bison sp. }\end{array}$ & $\begin{array}{l}\text { Bison } \\
\text { Bison } \\
\text { Bison }\end{array}$ & $\begin{array}{l}\text { F-40527 } \\
\text { F-40523 } \\
\text { F-38522 }\end{array}$ & $\begin{array}{l}\text { Right } \\
\text { astragalus } \\
\text { Left scapula } \\
\text { Right mandible } \\
\text { Left } 2^{\text {nd }} \\
\text { phalanx }\end{array}$ \\
\hline $\begin{array}{l}\text { McMinnville } \\
\text { area }\end{array}$ & $\begin{array}{l}\text { Bison antiquus } \\
\text { Paramylodon } \\
\text { harlani } \\
\text { Mammuthus } \\
\text { columbi }\end{array}$ & $\begin{array}{l}\text { Bison } \\
\text { Harlan's } \\
\text { ground sloth } \\
\text { Columbian } \\
\text { mammoth }\end{array}$ & $\begin{array}{l}\text { pending } \\
\text { pending } \\
\text { pending }\end{array}$ & $\begin{array}{l}\text { Right femur } \\
\text { Right humerus } \\
\text { Mandible }\end{array}$ \\
\hline Pratum & $\begin{array}{l}\text { Mammuthus } \\
\text { columbi }\end{array}$ & $\begin{array}{l}\text { Columbian } \\
\text { mammoth }\end{array}$ & pending & Molar \\
\hline
\end{tabular}

Based on prior knowledge and ecological background reviewed in Chapter 2, most of the taxa in this assemblage engaged in a feeding strategy focused on grazing in open environments (Table 5.3). Two of the specimens are mammoths, which are considered strict grazers associated with more open environments, such as grasslands or steppe. Eight of the specimens (six bison and two horses) are generally linked to grazing as well, but likely practiced considerable flexibility in diet. Horses are more often 
associated with open environments, while extinct bison are thought to have been capable of occupying a diverse set of habitats. Three of the fauna are sloths ( $P$. harlani) which are considered a mixed or intermediate feeder but one that focused on the exploitation of grasslands. Only, one browser, M. americanum, is included in the assemblage and is generally associated with more closed environments.

Table 5.3. Inferred Ecology of Late Pleistocene Megafauna Genera

\begin{tabular}{llll}
\hline Taxon & Common name & $\begin{array}{l}\text { Dietary } \\
\text { Specialization }\end{array}$ & Inferred Ecology \\
\hline $\begin{array}{l}\text { Mammuthus } \\
\text { Paramylodon }\end{array}$ & $\begin{array}{l}\text { Mammoth } \\
\text { Harlan's } \\
\text { ground sloth }\end{array}$ & $\begin{array}{l}\text { Grazer } \\
\text { Mixed/grazer }\end{array}$ & $\begin{array}{l}\text { Grassland or steppe } \\
\text { Grassland or parkland }\end{array}$ \\
$\begin{array}{l}\text { Bison (other than } \\
\text { modern } \text { B. Bison) }\end{array}$ & Bison & Flexible grazer & Diverse \\
Mammut & $\begin{array}{l}\text { American } \\
\text { Mastodon }\end{array}$ & Browser & $\begin{array}{l}\text { Forested and riparian areas, parklands } \\
\text { with bogs, swamps; marshes, ponds } \\
\text { Equis }\end{array}$ \\
\hline
\end{tabular}

All nine paleontological localities are located in the northern Willamette Valley (Figure 5.2). Three of the localities (Hillsboro, Tualatin, and Tualatin River-Fanno Creek) are situated in the Tualatin Valley, a sub-basin located in the northwestern portion of the Valley. Two of the localities, Pratum and Woodburn, lay on the central portion of the Valley floor east of the Willamette River. The three McMinnville area localities are situated west of the Willamette River, several kilometers east of the Coast Range.

The Hillsboro Locality (UO Locality 2666) is located in Washington County (Figure 5.2), two miles west of Hillsboro, Oregon. It is situated in the Tualatin Valley (a sub-basin in the northwest portion of the Willamette Valley) on a floodplain between Dairy Creek and Council Creek, 11/2 miles north of the Tualatin River at an elevation of $\sim 59 \mathrm{~m}(180 \mathrm{ft})$. The faunal materials were recovered from the bottom of a peat bog deposit situated approximately $2-4$ m beneath the surface (Barnosky 1978; Kittleman 1975, 1976b, 1976c). The peat bog formed over the Winkle Surface, a geomorphic unit 


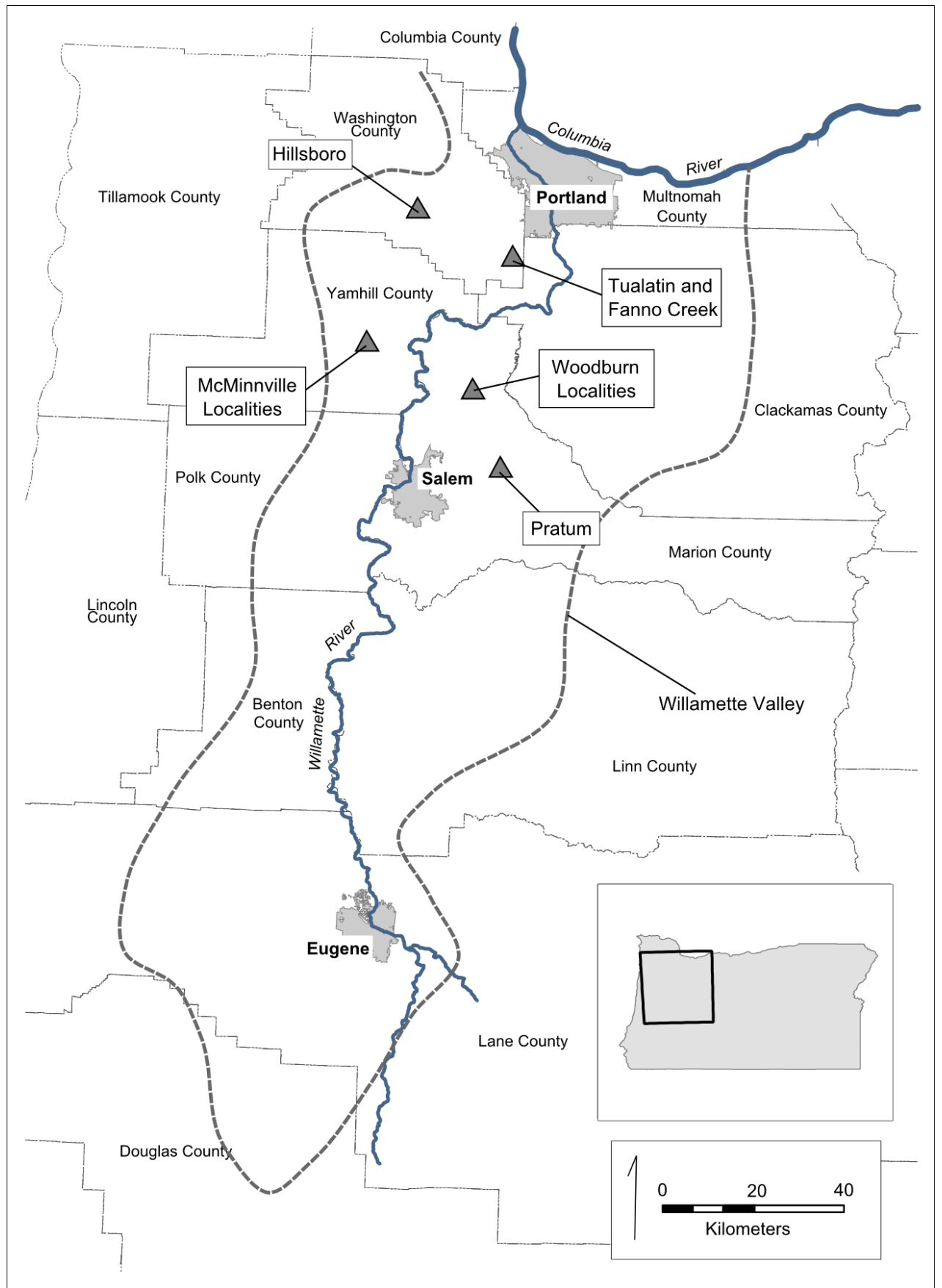

Figure 5.2. Locations of Paleontological Localities included in My Study 
estimated to post-date the last Missoula Flood event at 15,000 cal BP (Balster and Parsons 1968; O'Connor et al. 2001). The Hillsboro Locality was discovered in the mid1970s when farmhands uncovered a number of bones while preparing an agricultural drainage system. Researchers from both the University of Oregon and the University of Washington visited the Hillsboro Locality, collected fossils from spoils spread beside the discovery site, and recorded the stratigraphy of the drainage ditch (Kittleman 1976a, 1976b; Barnosky 1978). Three genera, each representing a single individual, are represented from this locality, mammoth (Mammuthus sp.), Harlan's ground sloth ( $P$. harlani), and extinct bison (B. antiquus).

The Tualatin Locality (UO Locality 2840) lies in the Tualatin sub-basin of the Willamette Valley within the limits of the City of Tualatin, Washington County, Oregon (Figure 5.2). The paleontological locality is situated at an elevation of $\sim 36 \mathrm{~m}$ (120 ft), approximately $450 \mathrm{~m}$ south of the Tualatin River and $100 \mathrm{~m}$ north of Nyberg Creek on the floodplain of the Tualatin River, a tributary to the Willamette River. The fossil material was recovered from a swampy area at a depth of $\sim 1-1.5 \mathrm{~m}$ below the surface (Addington 2006). While the Tualatin sub-basin was not included in O'Connor et al.'s (2001) study of surficial geological units in the Willamette Valley, it underwent the same processes of landscape evolution and is likely composed of fine-grained Missoula Flood deposits or alluvium of smaller streams dating to the Holocene and Upper Pleistocene. Given that the Missoula Floods blanketed this area with deposits of gravel and sediments that are in some areas over $30 \mathrm{~m}$ thick (O'Connor et al. 2001), this landform definitely represents a post-Flood origin $(<15,000 \mathrm{cal} \mathrm{BP})$. The fossil material was excavated in 1962 by two undergraduates at Portland State University (PSU) as part of their final 
project in a "Geology of Oregon" class at PSU (Addington 2006). This locality yielded a partial skeleton of a single individual of $M$. americanum, the American mastodon.

The Fanno Creek-Tualatin River Locality (UO Locality \# pending) is located in the City of Tigard, Washington County, Oregon (Figure 5.2). The Tualatin River-Fanno Creek Locality is situated west of and adjacent to Fanno Creek, approximately $1.2 \mathrm{~km}$ north of Fanno Creek's confluence with the Tualatin River at an elevation of approximately $\sim 45 \mathrm{~m}(148 \mathrm{ft})$. The fossil was recovered from a depth between $\sim 2-4.5 \mathrm{~m}$ (7-15 ft) below the surface from a swampy field in an area consisting of floodplains and gently inclined terraces. While the contextual information for this specimen is poor, the specimens likely post-date or are contemporary with Missoula Flood deposits, as the Willamette Valley lowlands were blanketed by deposits of gravel and sediments that are in some areas over $30 \mathrm{~m}$ thick (O'Connor et al. 2001). The fossil was discovered by backhoe operator while excavating for a sewage line project, sometime in the late 1960s or early 1970s (Yvonne Addington, personal communications 2008, 2009). This locality yielded a synsacrum (sacrum with attached last/third lumbar vertebra) of $P$. harlani, Harlan's ground sloth.

The Woodburn High School Locality (UO 2596) is located on the grounds of Woodburn Senior High School, in the city of Woodburn, Marion County, Oregon (Figure 5.2). The paleontological locality is situated within the Mill Creek drainage, a tributary to the Pudding River, at an elevation of $\sim 47 \mathrm{~m}$ (155 ft). O'Connor et al. (2001) designated most of this area as fine-grained Missoula Flood deposits or alluvium of smaller streams dating to the Holocene and Upper Pleistocene. The bison was recovered from a depth of approximately $5.1 \mathrm{~m}$ at the interface of a peat bog deposit and a greenish- 
blue micaceous silt. The peat bog has been identified in numerous places throughout the Mill Creek drainage in Woodburn and appears to have formed on (hence post-dates) ponded depressions on the surface of the Missoula Flood silts (Connolly 2003a). A postflood origin of these deposits is further supported by a number of radiocarbon dates that have been obtained from faunal and floral materials recovered from these deposits (Connolly 2003a). The fossil material was discovered during excavation by a backhoe for a high school biology class's paleoecology science project. A partial skeleton of an extinct bison, B. antiquus, was recovered from a peat bog deposit at this locality.

The Woodburn-Legion Park localities (UO Localities 3038, 3064, 3867) are located in the city of Woodburn, Marion County, Oregon (Figure 5.2). Legion Park is situated immediately adjacent to Mill Creek at an elevation of $\sim 42 \mathrm{~m} \mathrm{(170} \mathrm{ft).} \mathrm{O'Connor}$ et al. (2001) mapped the area as consisting of the main body of fine-grained Missoula flood deposits. A variety of faunal specimens have been recovered from the Woodburn peat bog deposits during a series of backhoe investigations at different locations in, or immediately adjacent to Legion Park, a public recreational area (Stenger 2003, 2006). While each instance of excavation has been granted its own unique locality number by the UO MNCH for administrative purposes, they are considered here as a single unit. As the fossil materials were recovered through use of a backhoe, geologic contextual data is sometimes coarse and it is not always clear which specific stratum or sub-stratum the fossils originated from. Regardless the Woodburn fossils in this study were noted as associated with either post-Missoula Flood peat bog deposits or other post-flood stratigraphic layers (Stenger 2003, 2006; UO MNCH database 2009). As with the previously discussed Woodburn High School locality, the peat deposits are considered to 
have formed on depressions on the surface of the Missoula Flood silts (Connolly 2003a). Five specimens recovered from Legion Park are included in this study, two equids (F37000 and F-38518) and three bison (F-38522, F-40523, and F-40527). These remains represent at least three individuals.

The Pratum-Rutschman/Qualey (PRQ) Locality (UO MNCH Locality \# pending) is located in the community of Pratum, Marion County, Oregon (Figure 5.2). The paleontological site sits on a low terrace of the Pudding River at an elevation of $\sim 64 \pm 3 \mathrm{~m}$ ( 209 ft) (Barton and Cearley 2008). O’Connor et al. (2001) mapped the area as the main body of fine-grained Missoula Flood deposits with Holocene and upper Pleistocene aged sediments along the banks of streams. The paleontological materials were discovered at a depth of 1.8-2.4 $\mathrm{m}$ from a bog that developed on a depression in Missoula Flood deposits (Cearley 2008). The fossils were discovered in 1967 by two men during a backhoe excavation for a farm pond (Barton and Cearley 2008; Cearley 2008). The remains of a single individual of Columbian mammoth (M. columbi) were recovered from the Locality.

The McMinnville Mammoth (UO Locality 3067) and the McMinnville Bison (UO Locality \# pending) paleontological localities are located in the city of McMinnville, Yamhill County, Oregon (Figure 5.2). The two localities are situated $33 \mathrm{~m}$ apart from

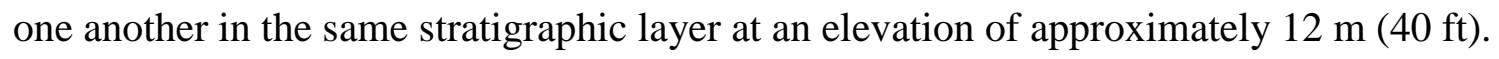
Both animals were discovered in the eroding vertical wall in the bank of the South Yamhill River. They were excavated from a late Pleistocene terrace deposit in a stratum with a high organic content (Bonnichsen et al. 2002:7; Stenger 2010a; Stenger and Fitzsimons 2007). This stratum is situated beneath Missoula Flood deposits, indicating 
an origin prior to $\sim 20,000$ cal BP. A partial skeleton of a single individual Columbian mammoth (M. columbi) was initially discovered by an avocational group in 1991 who brought the find to the attention of researchers at the UO MNCH and Oregon State University (Bonnichsen et al. 2002). Subsequent investigations in the area of the mammoth site resulted in the discovery of the bison (B. antiquus) (Stenger and Fitzsimons 2007; Stenger 2010a).

The McMinnville Sloth Locality is located in the city of McMinnville, Yamhill County, Oregon (Figure 5.2). Limited information regarding the geologic context of this specimen is known. The fossil was found protruding out of the bank of the South

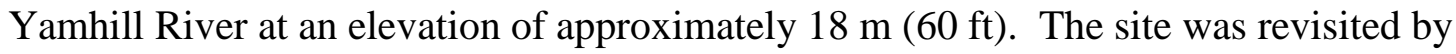
myself in September of 2010 in an attempt to learn more about the stratigraphic context and to ascertain if additional elements were present in the eroding bank of the River. Unfortunately, unusually high levels of rainfall in the Willamette Valley during the summer of 2010 thwarted our efforts. However, it was evident that given the considerable depth below the surface that the fossil was recovered from $(>15 \mathrm{~m})$, it must have hailed from a stratigraphic layer that either pre-dated or was contemporaneous with the Missoula Floods. More extensive study of the locality is planned for later this year. This specimen was discovered by two boys while they were playing several years ago. They brought the find to the attention of their father, who in turned notified the local avocational fossil group. A right humerus of a Harlan's ground sloth (P. harlani) was recovered from this location. 


\section{Taphonomy}

The fossil materials exhibit little evidence of taphonomic stress. No fossils bear any indication of cultural modification, burning, or rodent modification. Fourteen of the 15 specimens were characterized as Weathering Stage 1. A single specimen (WoodburnLegion Park bison scapula, specimen \# F-40527) was assigned to Weathering Stage 2.

One specimen, the femur of the McMinnville Bison (UO MNCH specimen \# pending), shows carnivore gnawing. The greater trochanter has been completely reduced by canids. In addition, the posterior portion of the femoral head shows scoring resulting from carnivore gnawing.

None of the fossils display any indication of transport by a Missoula Flood. There are no impact marks on bones from sediments/gravels transported by a high energy fluvial event. There are no abrasive striations or polish visible to the naked eye as expected if moving water brought bones into contact with gravels or sediments, or if particles transported by water had abraded bone (Fisher 1995:33-34). There are no modifications from river ice break up (Fisher 1995:45) such as conchoidal flaking, irregular flaking, and breakage. In sum, no specimens display erosion of the bone through application of force.

\section{Preservation of Bone Collagen}

As expected, the content of nitrogen and carbon contained in the XAD-treated hydrolysate is lower than published yields for well preserved collagen (Table 5.4). Nitrogen content ranged from 8.9-11.1\% N and averaged 10.1\% N. Carbon content ranged from $23.4-30.4 \% \mathrm{C}$ and averaged $27.6 \% \mathrm{C}$. The lower values are due to high concentrations of salts in the XAD-purified hydrolysate. Nonetheless, the carbon and 


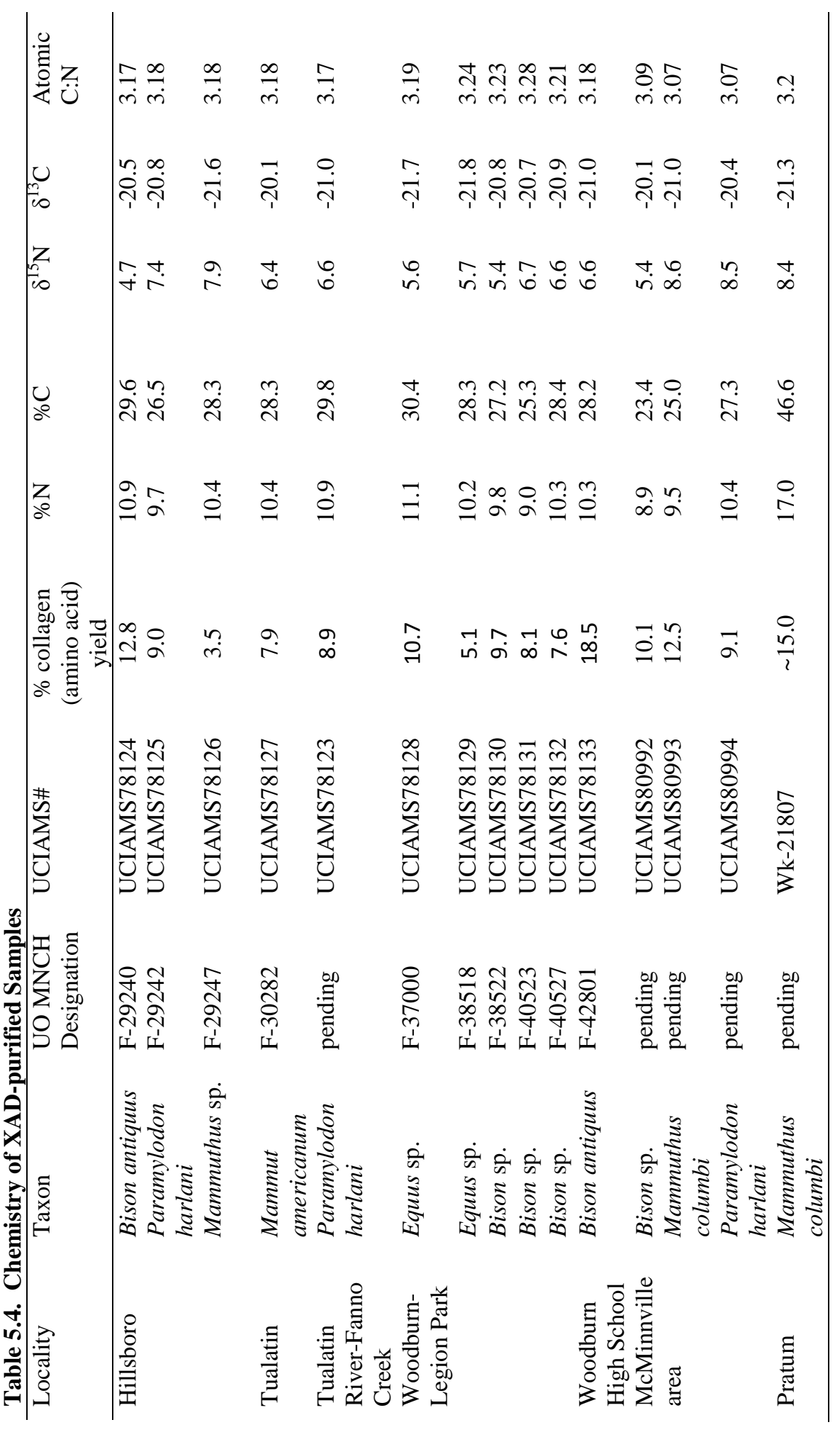


nitrogen content are below the suggested ranges of non-XAD prepared samples, but are within range of well preserved collagen that has undergone XAD-purification (Brendan J. Culleton, personal communication 2011; Douglas J. Kennett, personal communication 2010).

The atomic $\mathrm{C}: \mathrm{N}$ ratios of each specimen are within the acceptable range for unaltered collagen. The acceptable range for atomic $\mathrm{C}: \mathrm{N}$ ratios of unaltered bone collagen is 2.9-3.6 (Ambrose 1990; DeNiro 1985). The atomic C:N ratios (Table 5.4) for the samples in this study ranged from 3.09 to 3.28, and averaged 3.17. Each value is within scale for unaltered bone collagen.

The yields of collagen were also within range for unaltered collagen. Undeteriorated original collagen should return wt $\%$ collagen yields of between $\sim 1-21 \%$ of the original weight of the bone sample (van Klinken 1999). The wt \% yields of XADpurified collagen samples ranged from 3.5 to $18.5 \%$ (Table 5.4).

The bivariate plot of the atomic $\mathrm{C}: \mathrm{N}$ ratios and the wt \% collagen yields shows there is no significant relationship between $\mathrm{C} / \mathrm{N}$ ratio and collagen yields $(\mathrm{r}=.047, \mathrm{p}=$ $.436, \mathrm{n}=14)$ (Figure 5.3). This indicates that the bone collagen is unaltered and preserves the proper biogenic signal. 


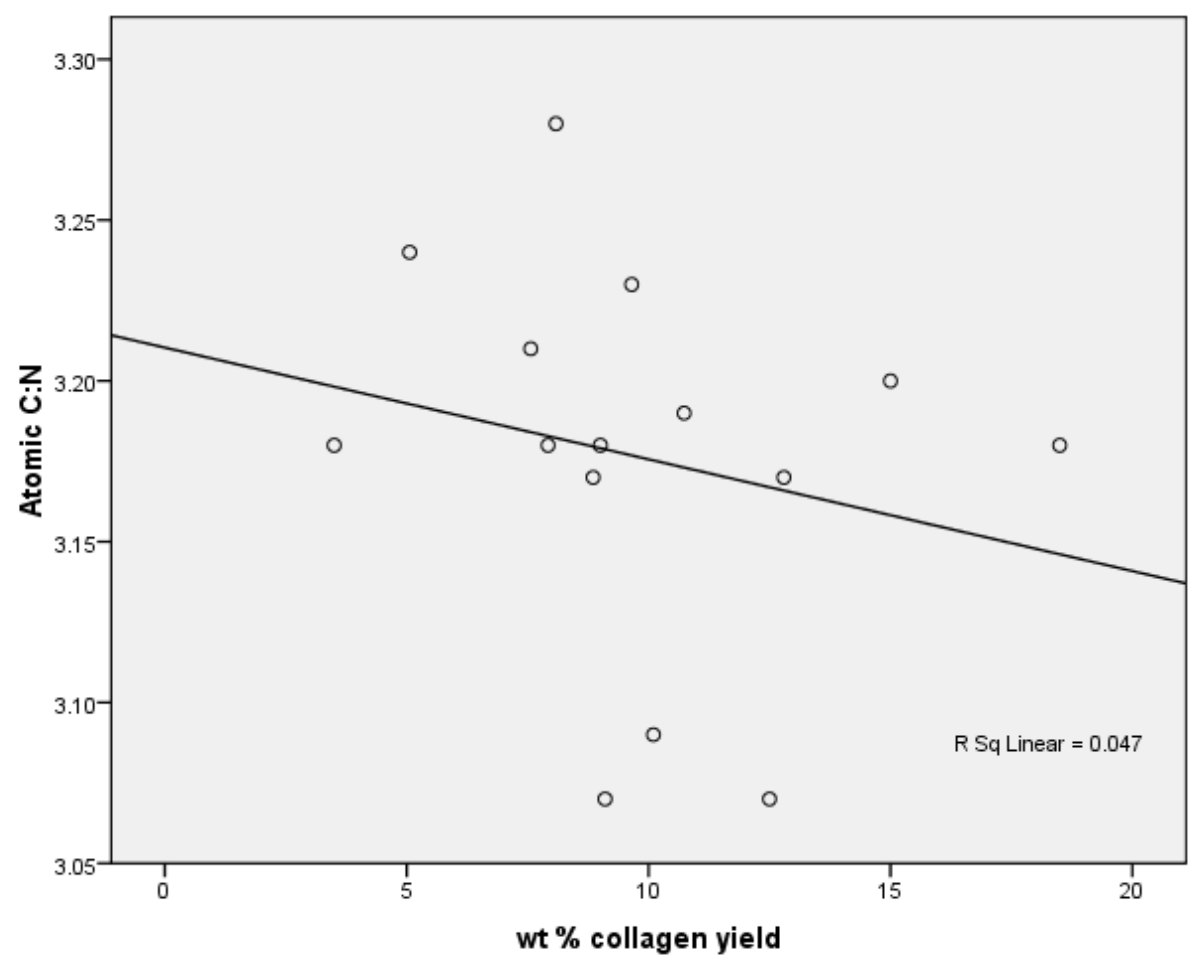

Figure 5.3 Bivariate Plot of Atomic C:N and wt \% Collagen Yield

The ultrafiltered PRQ Mammoth shows a nitrogen content of 17\% and carbon content of 46.6\%, with an atomic C:N ratio of 3.2 (Barton and Cearley 2008; and Cearley 2008). While collagen yield was not reported, I contacted the Waikato Lab and they reported that collagen yield was approximately $15 \%$ (Fiona Petchey, personal communication 2011). Though the reported $\% \mathrm{C}$ and $\% \mathrm{~N}$ appear higher than would be expected of unaltered bone collagen, the Waikato lab reported the sample to be in an acceptable state of preservation (Cearley 2008; Fiona Petchey, personal communication 2011). Overall, I assume the isotopic values and the state of preservation are acceptable. 


\section{AMS Radiocarbon Dating Results}

All AMS radiocarbon measurements are listed in Table 5.5. As noted above, most bone samples were analyzed three times to compare/contrast different pretreatments and labs. Figure 5.4 is a probability plot of the calibrated age ranges at two standard deviations of the measured radiocarbon ages. Original radiocarbon reporting sheets are presented in Appendix G.

\section{Comparison of Laboratories and Pretreatment Methods}

There was no systematic trend to the ages of the paired samples from the Arizona Lab. The Arizona Lab's ultrafiltered dates were just as likely to be younger or older than those samples subjected to their standard filtration method. In all but one instance (AA87425/u), there was no statistical difference between the Arizona Lab's filtration methods when the calibrated age range of each sample was expanded to encompass two standard deviations (Figure 5.5). The one instance this did not hold true was ultrafiltered sample AA87425u, the Hillsboro Mammoth (UO MNCH specimen \# F-29247). For reasons explained more fully below, the age of sample AA87425u is considered in error.

Comparing the XAD and Arizona Lab's results highlights two trends. First, in all instances the XAD-purified samples returned margins of error approximately one-third the size of measurements generated by the Arizona Lab. The average standard deviation in the XAD-purified samples measured by UCI was \pm 38.75 radiocarbon years, while the Arizona Lab standard deviation averaged \pm 123.75 for the ultrafiltered samples and \pm 115.67 for the standard filtered samples. The higher precision measurements from the UCI processing results from recent system upgrades to the UCI accelerator mass 


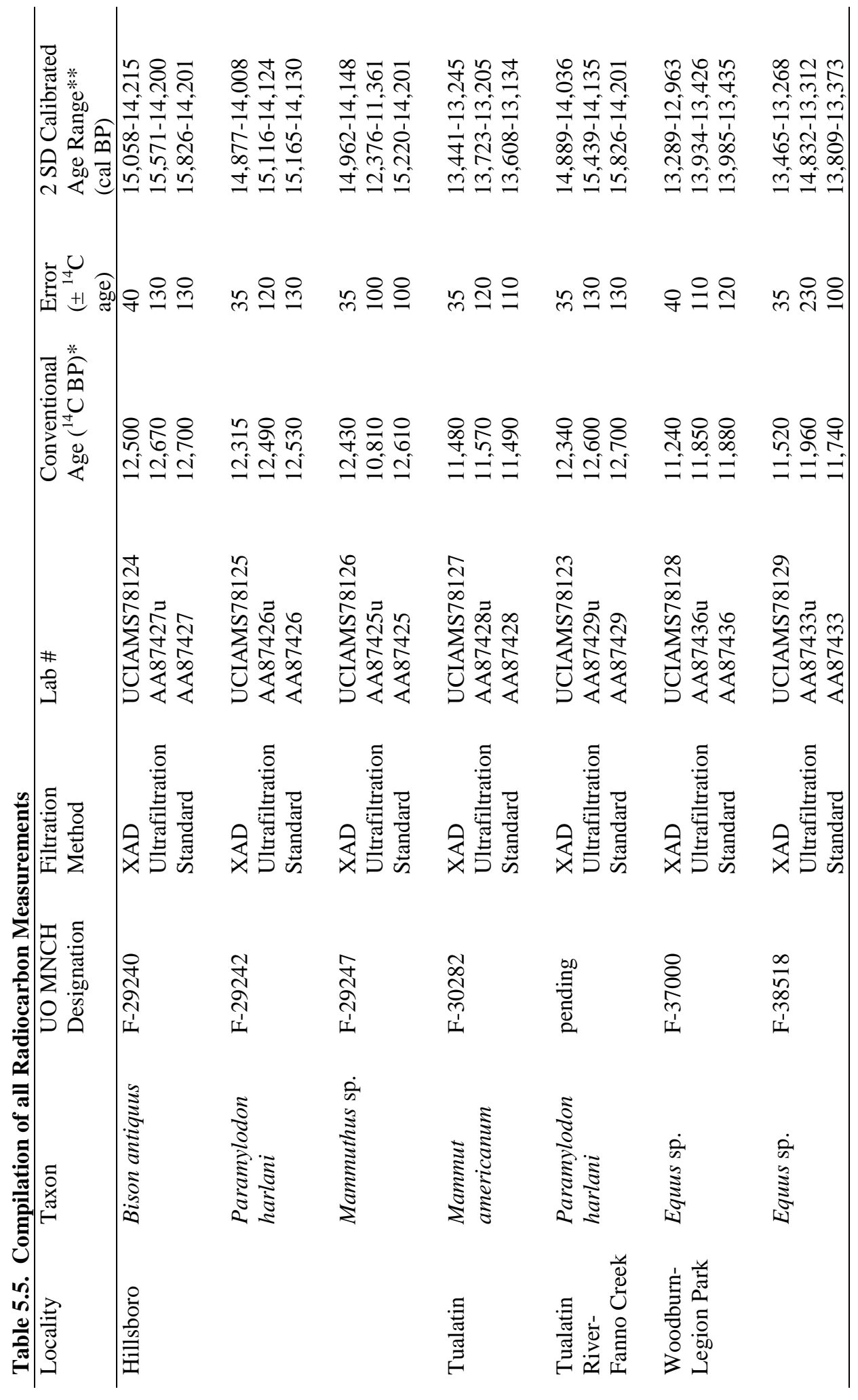




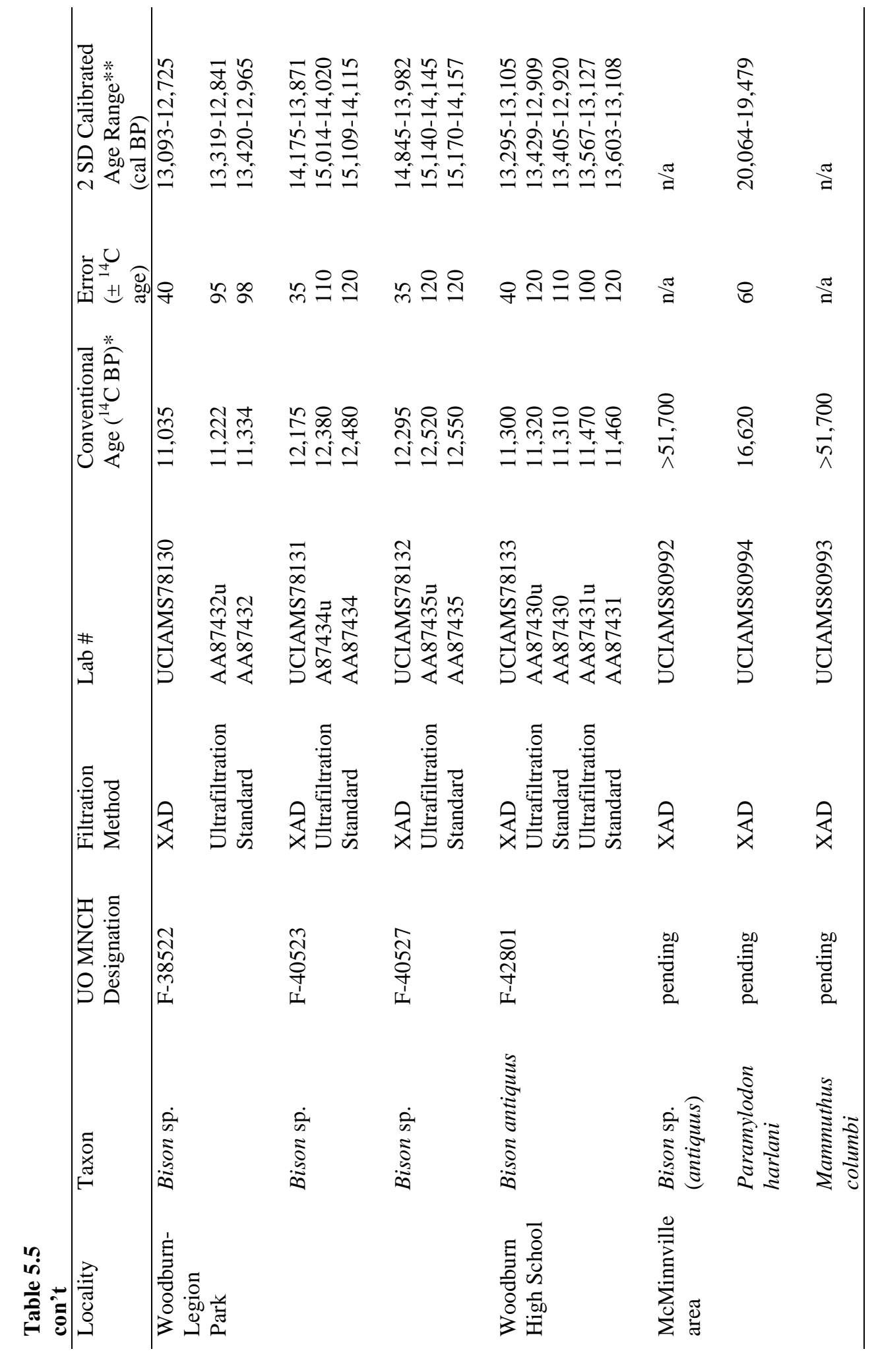




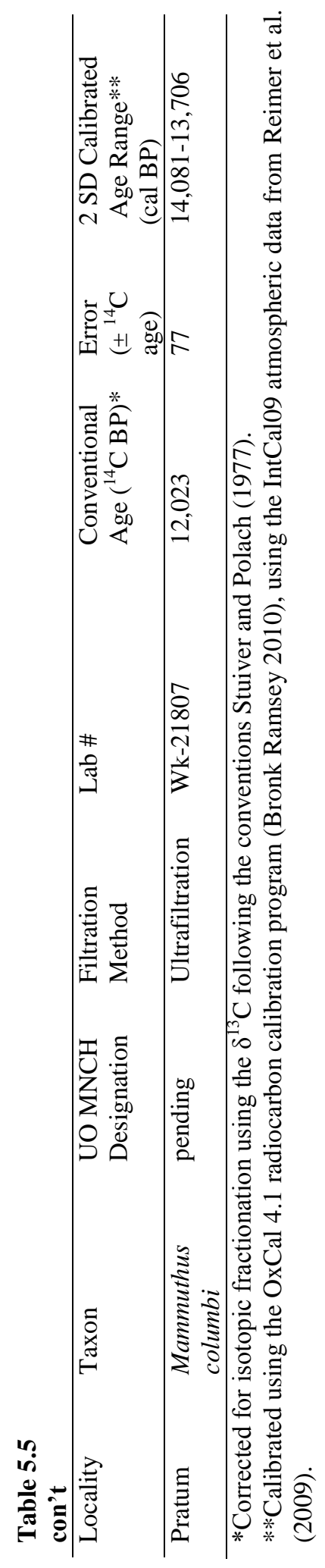


spectrometer rather than the XAD-purification process per se (Kennett et al. 2011).

Second, the radiocarbon age of each UCI/XAD-purified sample is younger than the measured radiocarbon age from the Arizona Lab, though they are generally similar when calibrated to two standard deviations (Table 5.5, Figure 5.4).

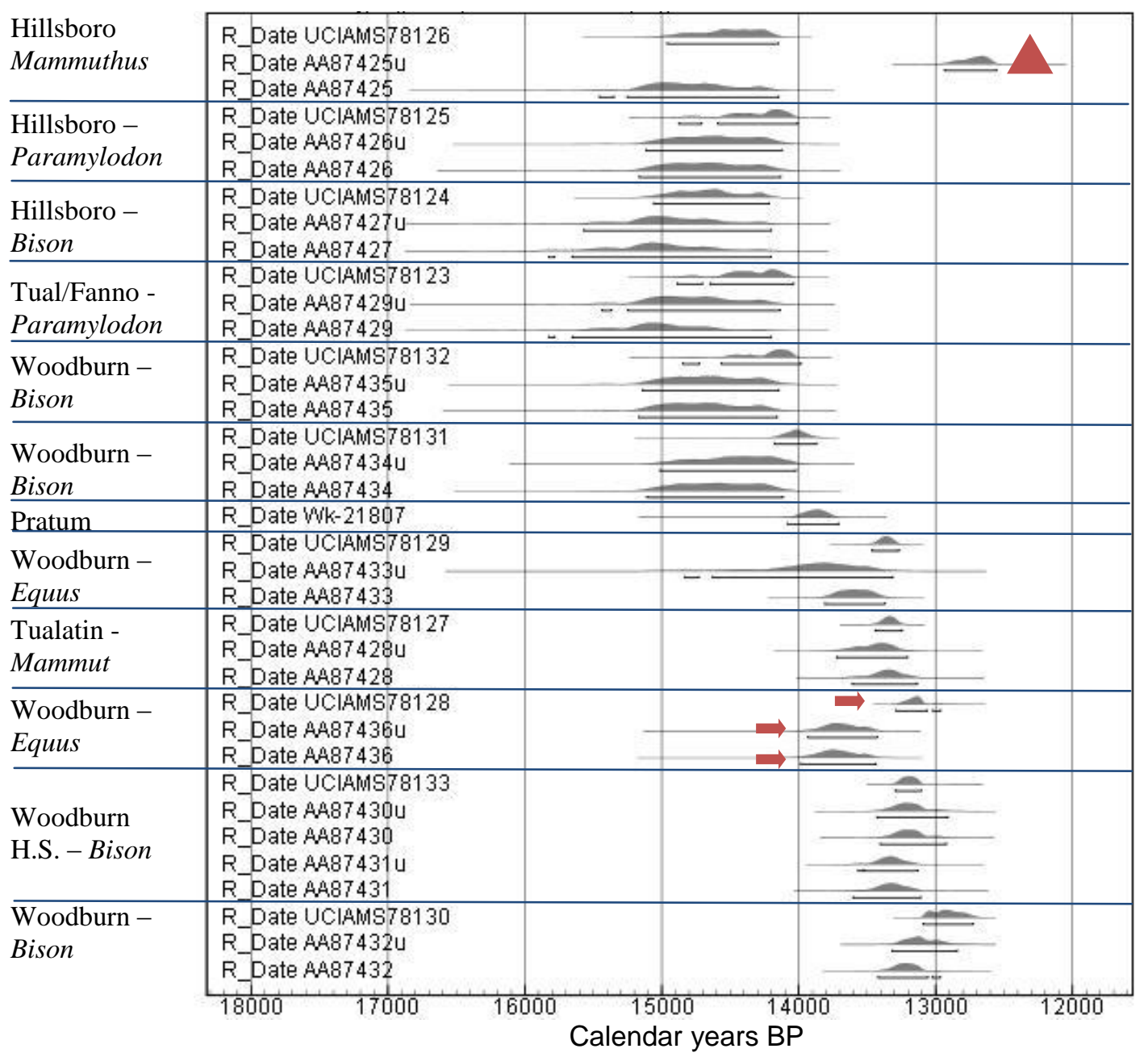

Figure 5.4. Probability Plot of Calibrated AMS Measurements of Post-Missoula Flood Specimens *Calibrated using OxCal v4.1.5 Bronk Ramsey (2010); Atmospheric data from Reimer et al. (2009) $\Delta=$ measurement is suggested to be in error. $\Rightarrow=$ statistical difference in measurements between labs.

Two factors may explain why the UCI ages are systematically younger than those from the Arizona Lab. First, it is possible that the XAD resin successfully removed older contaminating humates from the samples (Brendan J. Culleton, personal communication 
2011). While radiocarbon samples are typically assumed to have been contaminated with younger carbon, it is possible that they could also be contaminated by older carbon and the XAD-purification may have been successful at removing an exogenous contaminant, albeit an older one.

The second explanation for this systematic trend is differences in the use of radiocarbon blanks at the two labs. During the AMS dating process, samples of known age are routinely dated as quality control measures. Included in these samples of known age are "radiocarbon blanks," which are so old that they no longer possess a high enough level of ${ }^{14} \mathrm{C}$ to measure. As such, they are routinely employed to identify the level of modern carbon contamination in a set of samples. This level of modern contamination is then subtracted from all samples processed on the accelerator in that batch. One AMS laboratory could have a blank with a higher background than another. If that was the case, subtracting a higher background would make all the dates older in a particular batch (Brendan J. Culleton, 2011 personal communication). Regardless of the reason for the differences, the age estimates obtained from the two labs are not different at two standard deviations, except in two instances discussed below.

As an additional test for replicability, two samples from a single bone specimen (Woodburn High School Bison - UO specimen \#F-42801) were submitted to the Arizona Lab as two separate samples (AA87430/u and AA87431/u) as part of a blind test. The calibrated age ranges of each of these assays overlap at one standard deviation.

Radiometric results for two bone samples showed discrepancies which need evaluation. The first was the ultrafiltered sample AA87425u from the Arizona Lab for the Hillsboro Mammoth (UO specimen \#F-29247, designated by the $\Delta$ symbol in 
Figure 5.4), which is substantially younger than both UCI's (UCIAMS78126) XADpurified sample and the Arizona Lab's (AA87425) standard filtration sample. The XADfiltered sample (UCIAMS78126) and the Arizona Lab's standard filtered age (AA87435) for this specimen are statistically similar when calibrated to two standard deviations (Figure 5.4). Another radiometric assay is available from the original study of this paleontological locality (Sheppard 1977). A conventional radiocarbon measurement from bone collagen extracted from a cervical vertebra returned a measured radiocarbon age of $12,200 \pm 220 \mathrm{BP}$ (WSU 1740), which is also in agreement with UCI's radiometric measurement and the Arizona Lab's standard filtered age when calibrated. Lastly, the elemental and chemical data $(\% \mathrm{C}, \% \mathrm{~N}$, atomic $\mathrm{C}: \mathrm{N}$, and collagen yields) associated with the UCI-XAD age are in the range of well-preserved collagen. As the Arizona measurements lack chemistry data, it is not possible to independently evaluate their collagen. As three separate age estimates point to the older age, I suggest the younger Arizona ultrafiltered sample (AA87425u ) is in error.

Estimates also vary for a second specimen, a Woodburn horse (UO specimen \#F37000, designated by the $\Rightarrow$ symbol in Figure 5.4). The calibrated ages from the Arizona Lab (AA87436 and AA87436u) are statistically identical. The age of the UCI/XAD-purified sample (UCIAMS78128) is significantly younger. The UCI/XAD does not overlap with either of the Arizona Lab's measurements when calibrated to two standard deviations. All of the elemental concentrations and collagen with the UCI/XAD samples $(\% \mathrm{C}, \% \mathrm{~N}$, atomic $\mathrm{C}: \mathrm{N}$, and collagen yields) are within the range of wellpreserved collagen. Given that the Arizona samples lack these data, it is not possible to 
evaluate them. As such, I suggest that the radiometric ages of the Arizona samples (AA87436 and AA87436u) for this specimen are in error, and rely on the XAD results.

Through the rest of this study, I will restrict my discussion to the XAD-purified measurements generated by UCI and the PRQ Mammoth specimen (Barton and Cearley 2008; Cearley 2008). My rationale for this decision is two-fold. First, the dates from the two labs are generally not different when calibrated to two standard deviations. Second, I choose to focus on the UCI-XAD results because the accompanying collagen chemistry results demonstrate sufficient preservation.

\section{Ages of Megafauna}

Three of the 15 specimens have calibrated age ranges that pre-date the Missoula Floods (> 20,000 cal BP) (Table 5.5). Two of the specimens, the McMinnville Mammoth (UO specimen \# pending) and the McMinnville Bison (UO specimen \# pending)], returned infinite radiocarbon measurements of >51,700 BP (UCIAMS80992 and UCIAMS80993). Both of these specimens were recovered from a geologic stratum that pre-dated the Missoula Floods (Bonnichsen et al. 2002; Stenger and Fitzsimons 2007). Furthermore, the McMinnville Mammoth was previously subjected to AMS radiocarbon dating (Bonnichsen et al. 2002) that also returned an infinite age (CAMS77878). Given the above, the infinite dates associated with these two megafauna specimens appear credible.

The third late Pleistocene specimen was the McMinnville Sloth (UO specimen \# pending). This specimen returned a measured radiocarbon age 16,620 \pm 60 (UCIAMS80994). Unfortunately, there is only a minimal understanding of the geologic 
context of this fossil. Further study of this paleontological locality was precluded by unusually high water levels in the summer/fall of 2010.

Twelve of the 15 specimens returned calibrated age ranges that date to the terminal Pleistocene (Figure 5.5). The calibrated range of all terminal Pleistocene specimens falls within an approximately 2,000 year window between $\sim 15,000$ cal BP and $\sim 13,000$ cal BP. These ages correspond with the available information on the geologic context for the fossils, which indicates an origin post-dating the Missoula Floods. In addition, nine of these fossils were recovered during various paleoecological or paleontological investigations whose efforts, though usually not published, concluded that these fauna originated from post-Missoula Flood geologic contexts (Barton and Cearley 2008; Kittleman 1976a; Stenger 2002a, 2003, 2006).

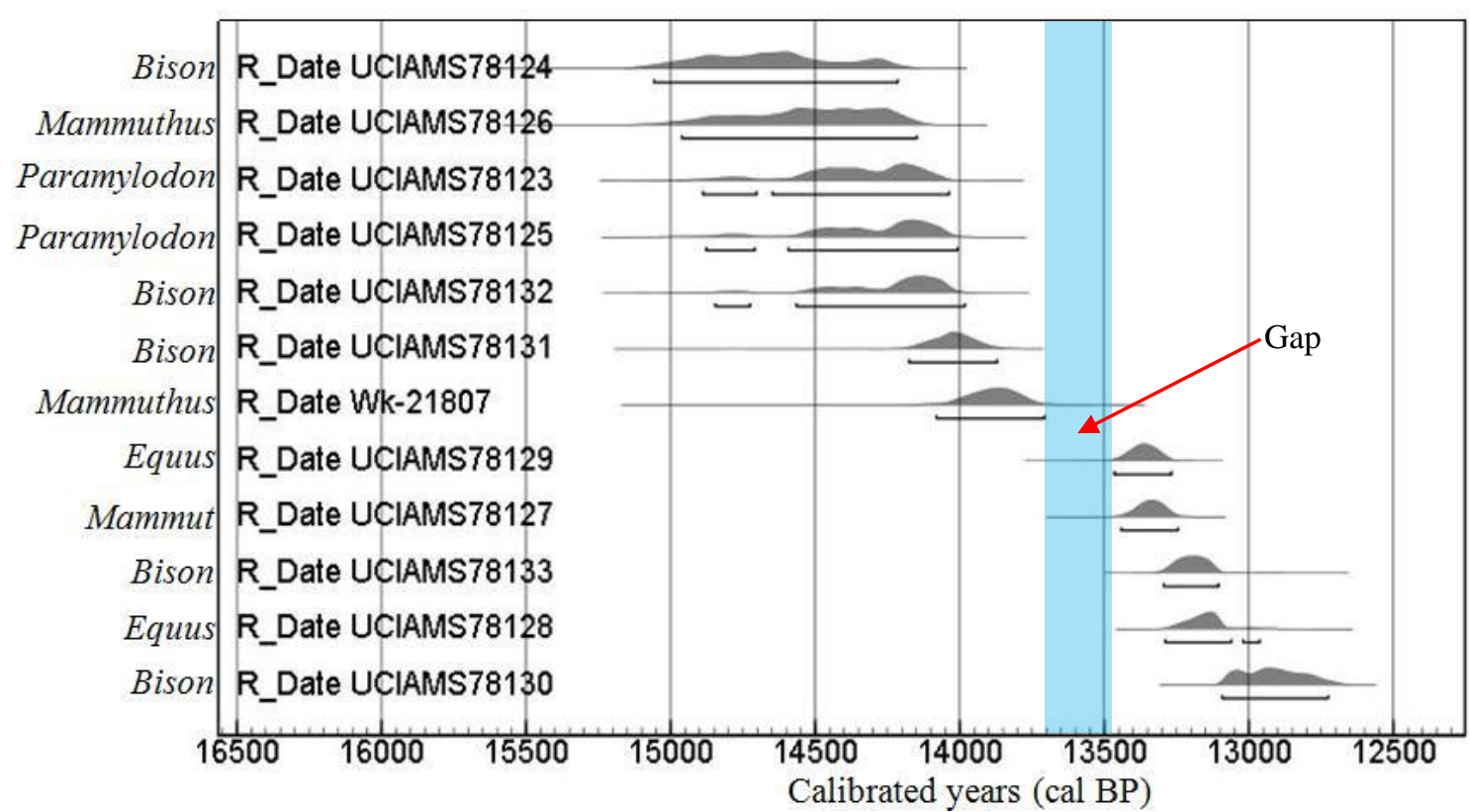

Figure 5.5. Calibrated Age Ranges of Terminal Pleistocene Specimens (samples that pre-date $\sim 15,000$ cal BP are excluded). Gap in fossil ages represented by transparent blue bar ca. 13,700-13,475 cal BP. 
Curiously, there is a gap in fossil age ranges during the terminal Pleistocene (Figure 5.5), from approximately 13,700 to 13,475 cal BP. While the gap is small, it is the only place in the terminal Pleistocene sequence in which the two standard deviation calibrated age ranges of megafauna failed to overlap. The gap may just be an effect of sample size, but it is noteworthy that the gap is situated after the one instance in which I employ a radiocarbon measurement (Wk-21807, the PRQ Mammoth) other than XADpurified dates from UCI. As reviewed in this chapter and presented in Figure 5.4, the XAD dates from UCI systematically produced younger measurements as compared to the Arizona Lab. If that pattern held true, then an XAD-filtered UCI date in this instance could possibly land in the gap beginning at $13,700 \mathrm{cal} \mathrm{BP}$. However, as the Archaeometry's Facility's attempt to extract a sample for AMS dating failed to yield sufficient collagen, I can only speculate as to whether the gap is real or resulting from inter-laboratory differences in the pretreatment and radiocarbon dating processes.

Bison, the most represented genera, is present throughout the 2,000-year terminal Pleistocene sequence. Considering the maximum and minimum extent of the calibrated age ranges, the age spans of Bison specimens are the most extensive, including both the oldest and youngest dates. The two sloth (Paramylodon) specimens are situated in the first half of the terminal Pleistocene cycle. The age ranges of the two Mammoth (Mammuthus) specimens fall in the earlier and middle portion of the terminal Pleistocene. The lone mastodon (Mammut) and both horses (Equus) are situated in the later temporal quartile.

Comparing the ages of localities is difficult. The fossil materials from the McMinnville area are older than the others, two individuals returned infinite ages 
(UCIAMS80992 and UCIAMS80993) while the third is 5,000 calendar years older than the materials from the post-Missoula Flood localities. Only the Hillsboro and WoodburnLegion Park localities have multiple specimens (Table 5.5, Figure 5.4). The calibrated age ranges of the megafauna from each of these two localities are compared in Figure 5.6.

The Woodburn-Legion Park specimen (UCIAMS78132) with the age range of greatest antiquity overlaps the age span of each of the megafauna from the Hillsboro Locality. The age range of another Woodburn-Legion Park specimen (UCIAMS78131) overlaps with two of the Hillsboro specimens (UCIAMS78125 and UCIAMS78126). As such, it is not possible to identify which locality is older, but Figure 5.6 shows that some of the Woodburn fauna are clearly younger. Moreover, a more concise period of time is represented by the Hillsboro Locality. At most, just over 1,000 calendar years is represented at Hillsboro, while Woodburn-Legion Park could represent a maximum timespan of over 2,000 calendar years.

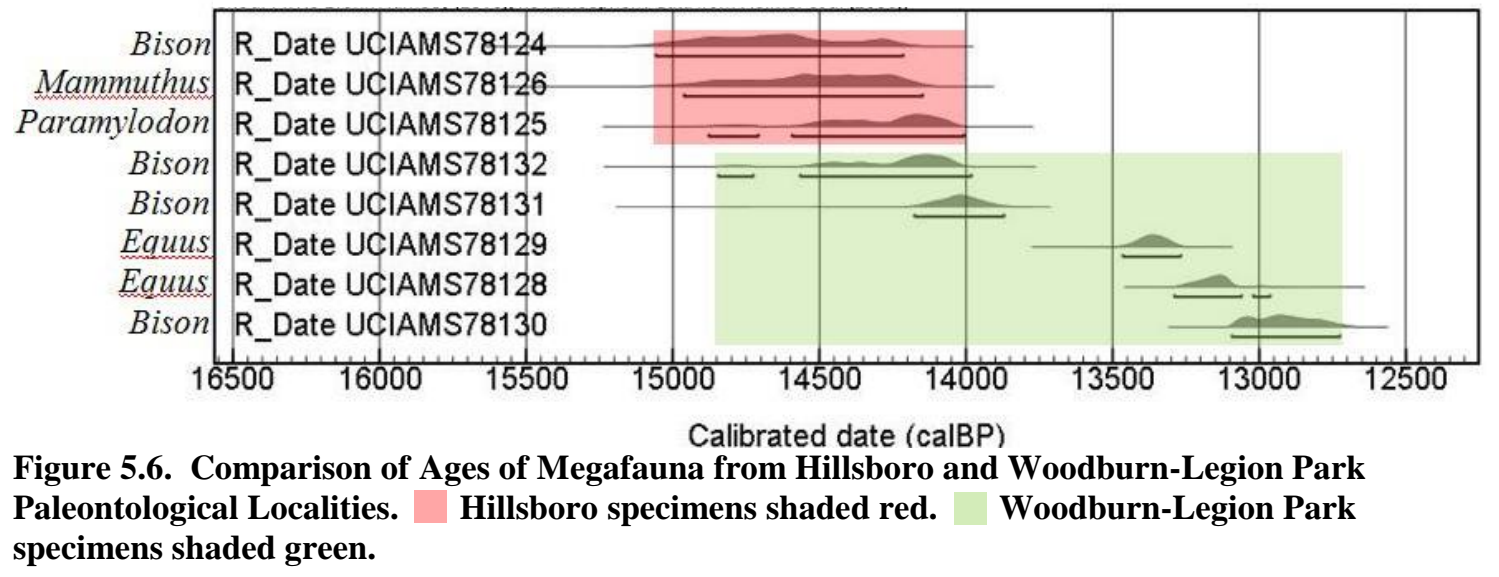




\section{Stable Isotope Analyses Results}

All stable isotope values are presented in Table 5.4. Bivariate analysis of both stable isotopes shows well-defined clustering by genera (Figure 5.7). The nitrogen isotopic data $\left(\delta^{15} \mathrm{~N}\right)$ yielded a range of 4.7-8.6\%, while the carbon isotopic data $\left(\delta^{13} \mathrm{C}\right)$ yielded a much narrower range between -20.1 to $-21.8 \%$. Each genera is considered individually below.

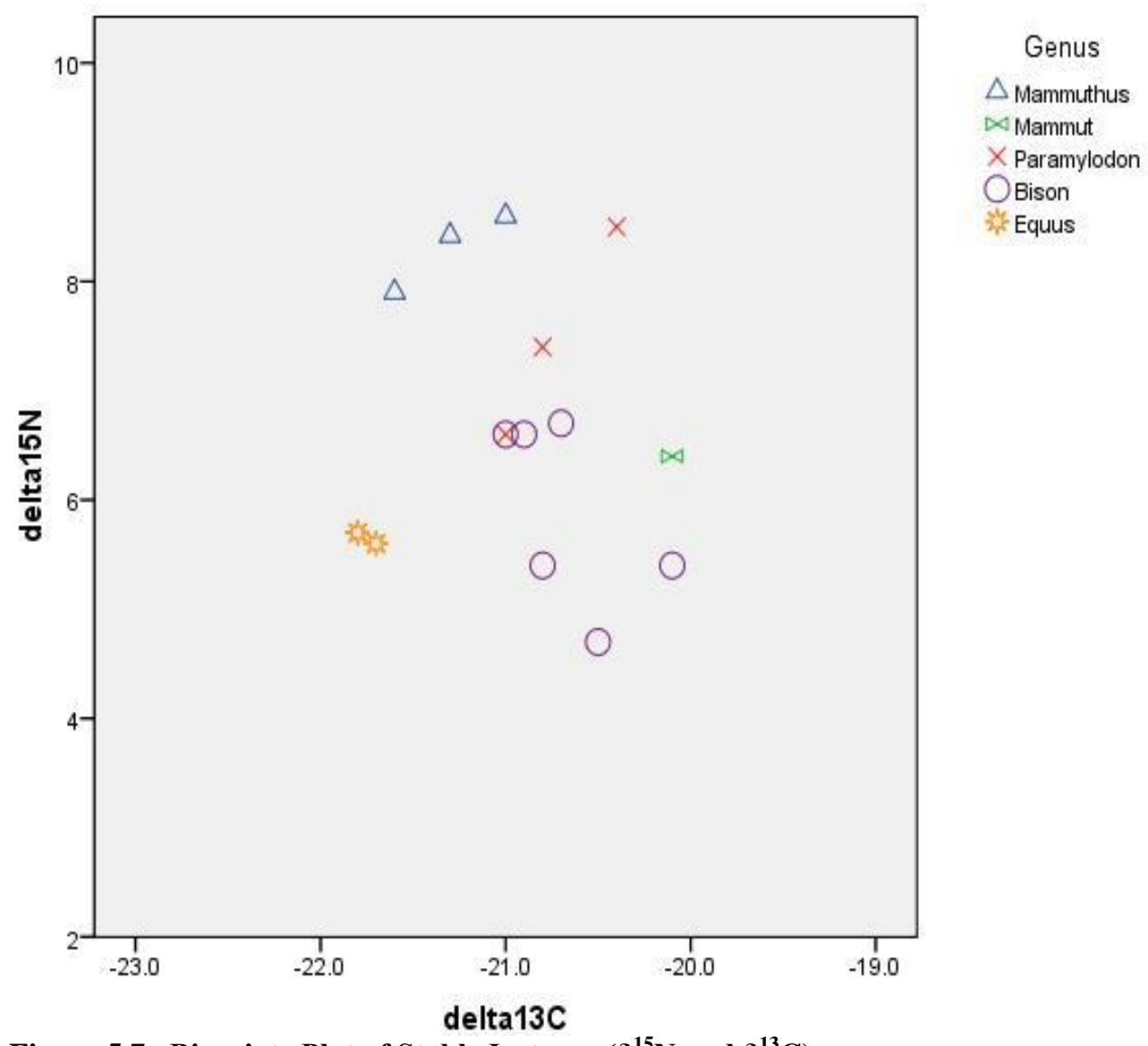

Figure 5.7. Bivariate Plot of Stable Isotopes $\left(\delta^{15} \mathrm{~N}\right.$ and $\left.\delta^{13} \mathrm{C}\right)$

As a group, the three Mammuthus specimens yielded the highest mean nitrogen stable isotopic values of any genera. $\delta^{15} \mathrm{~N}$ ratios varied between $7.9-8.6 \%$, a range of $0.7 \%$ with an average of $8.3 \%$. Mammuthus stable carbon isotopic ratios were the 
second most depleted and displayed the second least variation. $\delta^{13} \mathrm{C}$ ratios varied between -21.0 to $-21.6 \%$, a range of $0.6 \%$, and averaged $-21.3 \%$.

The three $P$. harlani samples exhibited ratios in both nitrogen and carbon that were highly variable. $P$. harlani $\delta^{15} \mathrm{~N}$ values were the second most enriched, ranging from 6.6-8.5\%o, and averaging 7.5\% . The mean sloth $\delta^{13} \mathrm{C}$ ratio was similar to Bison, averaging $-20.7 \%$ with a range of $0.6 \%$.

Equus was the most depleted genera in $\delta^{13} \mathrm{C}$, averaging $-21.75 \%$, with a range of only .1\%, as well as the most depleted in $\delta^{15} \mathrm{~N}$, averaging $5.65 \%$ with a range of $0.1 \%$. No two specimens from any genera were as similar to each other as the two Equus specimens were in both stable isotopes, enforcing the suspicion that the two skeletal elements actually represent only a single individual.

Bison was the most variable genera in both isotopes. In $\delta^{13} \mathrm{C}$, the six Bison averaged the second lowest ratio, 5.9\%o, with a range of $2.0 \%$, while the $\delta^{15} \mathrm{~N}$ mean was $-20.7 \%$ with a range of $0.9 \%$. Meanwhile, only a single mastodon is included in this study. In that one specimen, $\delta^{15} \mathrm{~N}$ measured $6.4 \%$ and $\delta^{13} \mathrm{C}$ registered $-20.1 \%$. Surprisingly, Mammut, widely recognized as a browser with a preference for forested habitat, equaled the most enriched individual $\delta^{13} \mathrm{C}$ measured in this study, a bison (UO MNCH specimen \# pending). 


\section{CHAPTER 6: DISCUSSION AND CONCLUSIONS}

This section explores the results in relation to the main research questions (Table $3.1)$.

\section{What is the origin/source of the paleontological remains?}

While the age range of one of the 12 terminal Pleistocene specimens (UCIAMS78124) overlaps the last of the Missoula Floods, 11 of the 12 ages post-date the last of the Missoula Floods (i.e., they are younger than 15,000 cal BP) (Figure 6.1). My work reviewed whether the megafaunal remains represented local animals or were transported in by Missoula Floods. Several factors suggest these remains reflect local animals. First, the geologic context of most of the paleontological localities is sufficiently understood to show that their origin is post-flood (it was recovered from a stratigraphic layer that was superimposed over Missoula Flood sediments or other younger Pleistocene sediments). Second, the taphonomic condition of the fossil material indicates in situ death/deposition. There is no indication that the bones had been exposed to such processes as impact from sediments/gravels transported by a high energy fluvial event such as the Missoula Floods. Third, four of the six terminal Pleistocene paleontological localities consist of more than isolated skeletal elements. Isolated skeletal elements would be expected if the fossil materials had been transported and scattered by fluvial forces. At three localities (Hillsboro, Woodburn High School, Tualatin), fairly complete skeletons were even recovered, and it is possible that they came from carcasses rafted in on ice floes. However, my test for this hypothesis is not supported. The distance between glacial erratics and localities is great (between 800 and 


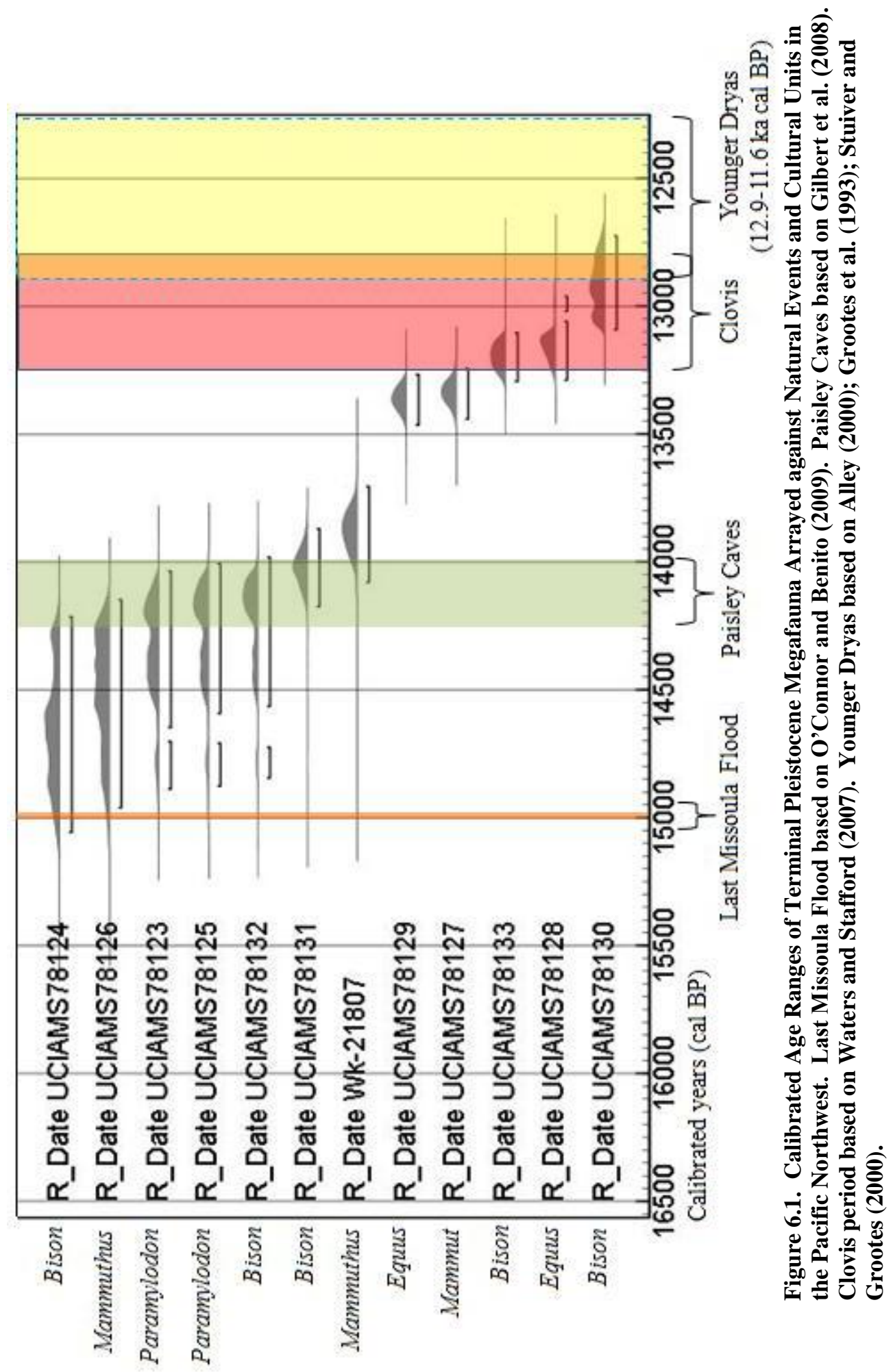


$4000 \mathrm{~m}$, Table 6.1), suggesting the carcasses did not arrive in the valley by the same source as the exotic boulders.

Table 6.1 Distances of Paleontological Localities from Glacial Erratics*

\begin{tabular}{lcr}
\hline Locality & $\begin{array}{c}\text { USGS GIS Glacial } \\
\text { Erratic Object ID }\end{array}$ & Distance (m) \\
\hline Hillsboro & 345 & 2,248 \\
Tualatin & 49 & 1,081 \\
Tualatin River-Fanno Creek & 173 & 803 \\
Woodburn High School & 124 & 2,860 \\
Woodburn-Legion Park & 124 & 4,034 \\
PRQ & 223 & 1,147 \\
\hline *GIS data on locations of glacial erratics drawn from Minervini et al. 2003.
\end{tabular}

\section{Was the loss of local megafauna related to climate cooling of the Younger Dryas}

\section{Stadial?}

The YD Stadial occurred from 12,900-11,600 cal BP (Alley 2000; Grootes et al. 1993; Stuiver and Grootes 2000). The decrease in temperature (as expressed in the Greenland ice cores) associated with the YD is arrayed against the radiocarbon calibration plot in Figure 6.2. None of the calibrated age ranges of the megafauna samples fall exclusively within the YD (Figure 6.1). Calibrated age ranges of 11 of the 12 terminal Pleistocene megafauna do not persist into the YD. The calibrated age range of only one specimen, a bison (UCIAMS78130), extends beyond the YD threshold. This specimen is from the genus Bison, a single species of which survived into the Holocene. The lack of radiocarbon ages exclusively within the YD is consistent with the explanation that climate change contributed to the decline in megafauna. Simply put, the onset of cooling conditions associated with the YD (Figure 6.2) created environments that were not suitable for larger bodied herbivores (see below for more review). 


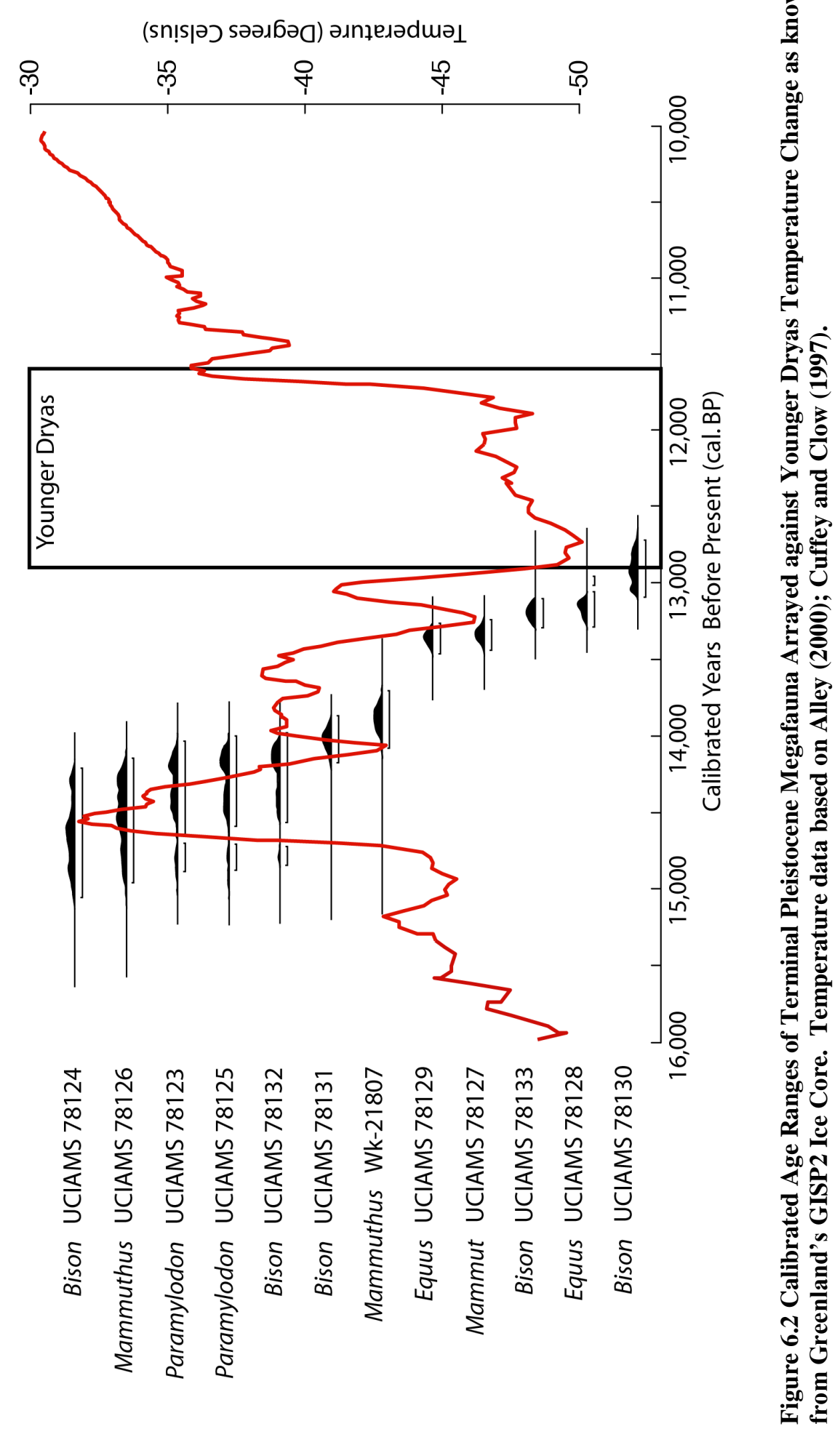




\section{What was the general character of Willamette Valley late Pleistocene environments?}

My study addressed various questions about the Willamette Valley ecosystem.

First, was the Willamette Valley an open environment or a closed canopy forest in the late Pleistocene? The stable carbon $\left(\delta^{13} \mathrm{C}\right)$ isotope values (Table 5.4, Figure 5.7) range from $-20.1 \%$ to $-21.8 \%$, all well within the range of an open environment (Bocherens 2003:58). The inferred ecology and dietary specializations of the studied taxa support the conclusion drawn from the isotopic data (Table 5.3, Figure 5.7). The megafauna community is mostly composed of taxa inferred to have been more adapted to open than closed environments. While the studied assemblage includes one browser $(M$. americanum) often associated with forested habitat and six bison that could likely tolerate a diverse array of environments, the other three genera are associated with open landscapes. While the data support the concept of an open environment in the late Pleistocene, records cannot identify specifically type of open environment, such as a grassland, steppe, or light forest. Next, the Willamette Valley megafauna can contribute to our understanding of the vegetation that characterized the Willamette Valley in the late Pleistocene. The study area straddles the $45^{\text {th }}$ degree of latitude. MacFadden et al. (1999) inferred ancient latitudinal gradients of $\mathrm{C}_{3}$ and $\mathrm{C}_{4}$ grasses based on the isotopic values of extinct equids. MacFadden et al. indicated that Pleistocene herbivores at high latitudes $\left(>45^{\circ}\right)$ almost exclusively consumed $\mathrm{C}_{3}$ plants with increasing consumption of $\mathrm{C}_{4}$ grasses by fauna south of $45^{\circ}$. The stable carbon isotope $\left(\delta^{13} \mathrm{C}\right)$ values range from $-20.1 \%$ to $-21.8 \%$, indicating a predominant or exclusive consumption of $\mathrm{C}_{3}$ vegetation and a general absence of $\mathrm{C}_{4}$ grasses in the diet of herbivores in the northern Willamette Valley. Thus, Willamette Valley vegetative communities were not composed of warm 
weather $\mathrm{C}_{4}$ grasses (i.e., vegetative communities were predominantly composed of $\mathrm{C}_{3}$ plants). The transition from $\mathrm{C}_{3}$ to $\mathrm{C}_{4}$ vegetation occurred south of the northern Willamette Valley.

\section{What is the relationship between fossil age and the record for late Pleistocene vegetation change in the region?}

Late Pleistocene vegetation change known from Battle Ground Lake (Walsh et al. 2008) shows a succession of three vegetation zones: parkland/tundra, open forest or parkland, and forest (Figure 6.3). The calibrated age ranges of the megafaunal samples span the three vegetative zones, though they are less common in the forest zone.

The calibrated age ranges of five of the megafauna overlap the boundary between parkland/tundra period and the successive vegetative zone of open forest or parkland (UCIAMS78123-6, UCIAMS78132). Four specimens date exclusively to the open forest or parkland period (Wk-21807, UCIAMS78127, UCIAMS78129, UCIAMS78131). The calibrated age ranges of three of the specimens extend into the forest period (UCIAMS78128, UCIAMS78130, UCIAMS78133). One of these (UCIAMS78130), a bison, falls exclusively in the forest temporal zone. As portrayed in Figure 6.3, the loss of fauna correlates with increased forested conditions locally. Joining with the previous review of the YD, these data support the proposition that climate change affected the character of vegetal communities, and in turn contributed to declines in megafaunal populations in the Willamette Valley. Unfortunately, the 2,300 year age span of the 


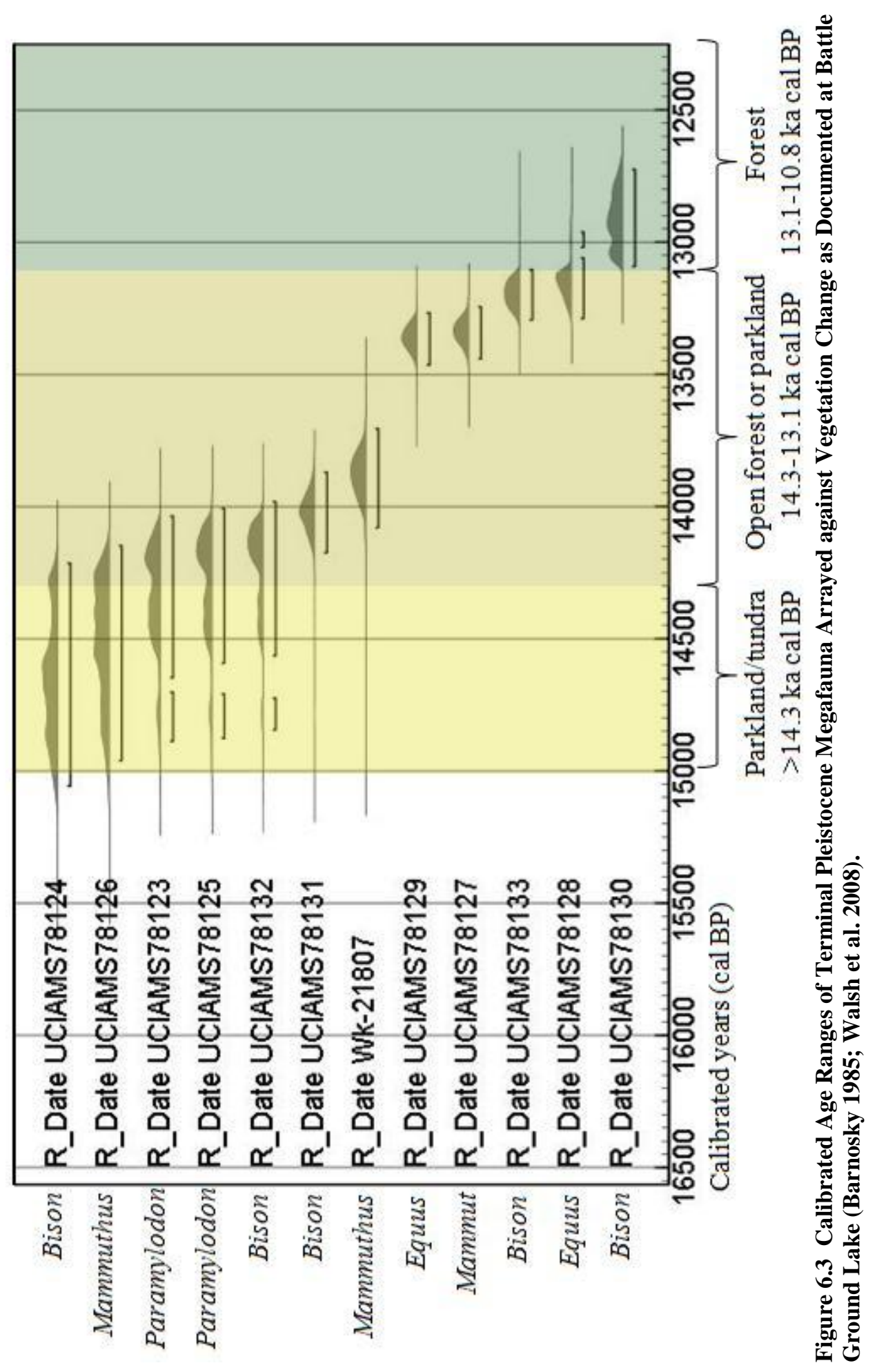


forest zone (13,100-10,800 cal BP) (Walsh et al. 2008) makes it difficult to rigorously test this linkage.

Isotopic records from the multiple Bison specimens offer an opportunity to track individual response to vegetation change. Figure 6.4 plots the stable carbon $\left(\delta^{13} \mathrm{C}\right)$ isotopic values of each of the bison included in this study. While the sample is small $(\mathrm{n}=6)$, the Willamette Valley Bison trend showing increasingly depleted values across time is in the direction of more closed conditions, though specific ratios are not as low as those noted for closed canopy conditions in other settings (Bocherens 2003; van der Merwe and Medina 1991).

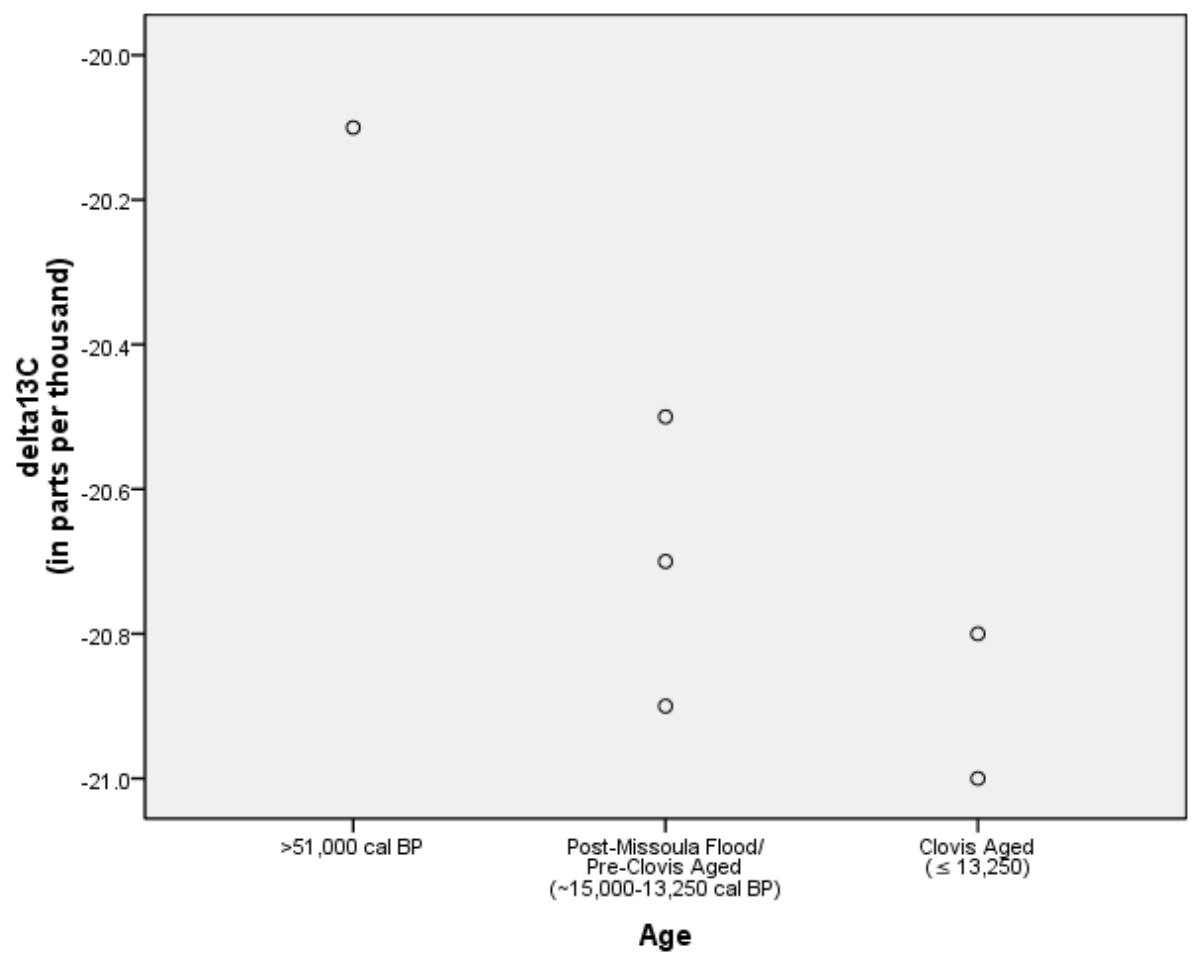

Figure 6.4 Plot of Diachronic Change in Stable Carbon Isotopic Values $\left(\delta^{13} \mathrm{C}\right)$ in Bison 


\section{What is the relationship between fossil age and the known timing of human occupation in the Pacific Northwest?}

The earliest record for human occupation from the Pacific Northwest comes from the Paisley 5 Mile Point Caves in south-central Oregon, which dates about 1,000 years prior to Clovis culture (Gilbert et al. 2008). Human coprolites recovered from the Paisley Caves were radiocarbon dated to approximately 14,270-14,000 cal BP (Figure 6.1). The archaeological evidence thus supports a pre-Clovis occupation of the Pacific Northwest.

The timing of occupation of Paisley Caves is plotted against the calibrated age ranges of the fauna in this study in Figure 6.1. Seven calibrated radiocarbon ages are contemporaneous with the occupation of the Paisley Caves, showing that megafauna were present in the Willamette Valley during the earliest confirmed human presence in the region.

After Paisley Caves, other records from P/HT foraging groups exist in the northern Great Basin of south-central and eastern Oregon (Jenkins et al. 2004). The Dietz Site (Pinson 2011; Willig 1989; Willig and Aikens 1988) was the first unequivocal Clovis site known in Oregon. The site contains both fluted points and Western Stemmed points. Two other Clovis fluted point sites are now recognized in southeastern Oregon, the Sheep Mountain Site (O'Grady et al. 2009) and the Sage Hen Gap Site (O'Grady et al. 2008). Moreover, surveys have identified a number of fluted points in eastern Oregon (O’Grady et al. 2009; Thomas et al. 2008). Waters and Stafford (2007) recently reevaluated and adjusted the temporal span of the Clovis window to 13,250-12,800 cal BP. While Western Stemmed points are generally associated with a post-Clovis occupation in Oregon (Jenkins et al. 2004; Willig 1989), recent research (Beck and Jones 
2010) has suggested that the Western Stemmed tradition was at least coeval, if not earlier, than Clovis in the Intermountain West. These data clearly point to a presence within the state of Oregon by Clovis peoples and other Paleoindian or paleo-archaic groups.

In the Willamette Valley, Connolly (1994) documented six "paleo-point occurrences" (Allely 1975; Cressman 1947; Heinz 1971; Minor 1985). These finds typically consist of isolated, temporally diagnostic projectile points from undated contexts. Specifically, Connolly noted isolated discoveries of four Clovis points and two Western Stemmed points.

Ozbun et al. (1997) noted the presence of 12 Clovis points in western Oregon. Four of these 12 were located in the Willamette Valley and were the same four included in the study discussed above by Connolly (1994). Ozbun et al. refer to these artifacts as "circumstantial evidence" for Paleoindian occupation. They write that the discoveries of these points suggest a widespread, however faint, presence of Paleoindians in western Oregon. Unfortunately, these finds lack provenience or association with other materials that could shed light on Paleoindian activities. However, they do support the concept of an occupation of the Willamette Valley by human foraging groups ca. 13,250-12,800 cal BP.

The timing of the Clovis Horizon is depicted against the probability plot of the calibrated radiocarbon ages in Figure 6.1. The age ranges of four of the radiocarbon assays are contemporaneous with the maximum date range of Clovis as set forth by Waters and Stafford (2007). Moreover, the calibrated age ranges of these four specimens extend the length of the Clovis Window. Importantly, no radiocarbon age is younger than Clovis. 
As originally proposed by Martin $(1967,1973)$, the overkill hypothesis suggests Clovis hunters spread into the New World and relatively quickly hunted megafauna to extinction. To Martin then, the absence of dated remains of megafauna in post-Clovis times is consistent with his model. Turning to the Willamette Valley records, the absence of megafaunal remains that date to post-Clovis times is also consistent with the overkill model.

When all 12 of the Terminal Pleistocene radiocarbon measurements are considered, the data indicate that megafauna were on the landscape prior to, and were contemporaneous with, Paleoindian groups of the Willamette Valley. It is possible that Willamette Valley Paleoindian people may have pursued "big game" as part of their subsistence regime, but no sites show unequivocal evidence of cultural materials and megafaunal remains.

\section{Conclusions}

For decades, scientists have questioned the connection between the timing of the mammalian megafaunal extinctions in the late Quaternary and the archaeological visibility of the first Paleoindian culture complexes in North America. Grayson (2007) has recently commented that the lack of resolution in the debate over both the timing and the causes of the extinctions in North America results from a deficiency in understanding the histories of each individual species of extinct animal on a local level. To help sort out causes for extinction, detailed regional chronologies of fauna are necessary for comparison with paleoenvironmental and archaeological data. This thesis makes a contribution in this respect through the development of a radiocarbon chronology and 
paleoenvironmental study of five genera of extinct late Pleistocene fauna recovered from the Willamette Valley.

Most bone specimens submitted for radiometric analysis were dated multiple times, at different laboratories, using different pretreatment methods which allowed an opportunity to evaluate different methods in the AMS radiocarbon dating process. The samples purified using XAD by the Archaeometry Facility (Archaeometry Facility of the Department of Anthropology at the University of Oregon) always returned younger measured ages than the Arizona Lab (NSF-Arizona AMS Laboratory), though the differences were not significant. This systematic trend could be explained in two ways. XAD may have removed older contaminants from the samples or the radiocarbon labs use of different blanks. The samples processed by UCI (Keck Carbon Cycle AMS Facility at the University of California, Irvine) were of higher precision, returning margins of error approximately one-third the size of measurements generated by the Arizona Lab. This difference probably results from recent system upgrades at UCI.

The data gathered answered several questions regarding the natural and cultural history of the Willamette Valley in the final millennia of the Pleistocene. First, the megafaunal fossil materials are autochthonous to the Willamette Valley. They are not the result of transport during Missoula Flood events. Second, extinct mammalian megafauna were present in the Willamette Valley contemporaneous with the earliest known human occupation of the region. Third, the megafauna were on the valley landscape prior to and during the Clovis Paleoindian Horizon. Consistent with the overkill hypothesis, radiometric ages span the length of the Clovis window, but no fauna are younger than Clovis. Fourth, none of the ages of the megafauna fall exclusively within the YD Stadial, 
suggesting that a decline/loss of megafauna occurred at the YD threshold (12,900 cal BP). Fifth, the timing of the loss of megafauna coincides with increased forested conditions in the region, suggesting that climate change impacted megafauna. As the timing of megafaunal decline correlates with the onset of the YD, increased forested conditions, and Clovis, it is not possible to distinguish the cause of extinction in the Willamette Valley. Paleoenvironmentally, the stable isotopic data indicates that the megafauna occupied an open landscape and consumed $\mathrm{C}_{3}$ vegetation. The inferred dietary specializations and habitat preferences of the fauna also supports the contention that the Willamette Valley was a more open landscape in the late Pleistocene prior to $\sim 13,000$ cal BP.

In addition to the research questions that were addressed, this thesis made three significant strides in terms of bringing order to the Pleistocene paleozoological record in the Willamette Valley. First, not since Hay (1927) had any researcher attempted to catalogue the reported finds of megafauna and inquire into Pleistocene fauna and ecology. Given the scattered and poorly documented record, it is not surprising that for decades there has been little to no professional awareness of the potential of the vertebrate record, much less genuine scientific interest in this region. This study could be a springboard to heighten awareness of the region to the scientific community and hopefully launch more intensive research.

This thesis project has also helped bridge the divide that has separated professional from private collection interests in fossil materials. Most of the Willamette Valley is privately owned land and most of the archaeology and paleontology is situated on private land. From the initial planning of this thesis, it was anticipated that public 
outreach would be vital to its success. I endeavored to build relationships with private collectors and historical societies so that private collections could contribute to scientific knowledge. Over the last two years, I gave several public lectures and interviewed multiple amateurs. I found a public audience that was highly interested in exploring the region's past and equally interested in developing relationships with professionals that could offer them guidance and leadership. Overall, these efforts will hopefully result in better relations between all interested parties in future research efforts.

Lastly, my experience in creating the catalogue of reported finds, attempting to relocate previously reported finds, and interactions with collectors highlighted the need to secure the preservation of fossil material through joint partnerships between members of the public and professionals, in a proper repository that has full institutional support. None of the reported finds from the early $20^{\text {th }}$ century could be relocated. Many were in private collections, and thus it is not surprising that they are out of reach, if they even still exist. I can only speculate as to how many other unreported and undocumented finds have/will occur on private property. However, some of the fossil material noted by researchers were at one time curated at the $\mathrm{UO} \mathrm{MNCH}$. I could not discern the fate of those fossils either. The UO MNCH lost institutional support in the 1970s and was effectively dismembered thereafter. Until recently, the paleontological collections were maintained by volunteers, a situation remedied only in recent years.

This situation highlighted two pressing needs. First, without full institutional support, even curation in an official repository is uncertain. The UO MNCH has suffered due to lack of financial support over a period of decades. It is the only repository of its kind in the state of Oregon and plays a vital role in preserving and documenting the 
state's past. Its own preservation is tantamount to any effort in the historical sciences.

Second, professionals need to develop mutually beneficial relationships with the public both individuals and nonprofit organizations such as historical societies, private persons and groups. In the past, fossils have gone to the UO MNCH or the UWBM and that is the last any member of the public heard of them. In the course of the public outreach portion of this thesis, one collector referred to the $\mathrm{UO} \mathrm{MNCH}$ as "the place where fossils go to die." This has contributed to the reluctance some private groups have shown at entering into relationships with the $\mathrm{UO} \mathrm{MNCH}$.

In this study, six of the fossils studied in the specialized analyses were in private hands. Some of the individuals or organizations already had some form of relationship with the UO MNCH, others I introduced to the UO MNCH staff. Each of these fossils has subsequently been accessioned into the $\mathrm{UO} \mathrm{MNCH}$ or the owners are in the process of developing some form of official relationship with the UO MNCH to safeguard the materials for longevity in the museum's collections while the fossils remain on display at their current home. These actions are an example of steps that need to be taken in order to protect these materials in the long term, while at the same time serving the public.

\section{Future Work}

Future research should consist of three steps in order to improve our understanding of terminal Pleistocene environments in the Willamette Valley. First, we need better chronological resolution in pollen cores upon which paleoenvironmental reconstructions are based. For example, this study arrayed the timing of the ages of megafauna versus vegetation succession as recorded at Battle Ground Lake (Walsh et al. 2008). The megafauna recorded ceases in Walsh et al.'s forest zone, which lasted from 
13,100-10,800 cal BP. This 2,300 year window encompasses most of the Clovis Paleoindian window, as well as the waning centuries of the Bølling-Allerød Interstadial, the entire YD Stadial, and the first 800 years of the early Holocene. Finer temporal resolution would help to constrain the extinction event(s) to periods of environmental upheaval or stability, or perhaps even a specific climatic event.

Second, the fossil materials recovered during the Woodburn backhoe projects are the most extensive late Pleistocene vertebrate record known in the state of Oregon. Despite their potential to inform on past environments, they have never been described. Myself and colleagues at PSU and the UO MNCH are now in the initial planning stages of analyzing and reporting the Woodburn materials.

Lastly, the terminal Pleistocene peat bogs that underlay the Woodburn area have the most promise of providing well-stratified deposits of megafauna. As the Woodburn bogs are deeply buried ( 1-5 m), past excavations employed the coarsest methods of recovery, sometimes resulting in the intermixing of materials between strata or sub-strata. Future investigations should explore alternative, finer scale methods in order to maintain provenience. 


\section{REFERENCES CITED}

Adams, Martin E.

2008 Mutual Climatic Range in Oregon: Reconstructing Paleoclimate of the Northern Willamette Valley Using a Fossil Beetle Assemblage. Unpublished master's thesis, Department of Anthropology, Portland State University, Portland, Oregon.

Addington, Yvonne S. (editor)

2006 Mastodon: The Tualatin Connection. Manuscript on file at the Tualatin Heritage Center, Tualatin, Oregon.

Agenbroad, Larry D.

2005 North American Proboscideans: Mammoths: The State of Knowledge. Quaternary International 126-128:73-92.

Agenbroad, Larry D., and Jim I. Mead

1996 Distribution and Palaeoecology of Central and Western North American Mammuthus. In The Proboscidea: Evolution and Palaeoecology of Elephants and Their Relatives, edited by J. Shoshani and P. Tassy, pp. 280-288. Oxford University Press, New York.

Aikens, C. Melvin 1993 Archaeology of Oregon. U.S. Department of the Interior, Bureau of Land Management, Portland.

Akersten, William A.

1976 Letter to Laurence R. Kittleman dated December 9, 1976 (RE: UO paleontological locality \#2666). Document on file at the University of Oregon Museum of Natural and Cultural History, Eugene, Oregon.

Allely, Steven

1975 A Clovis Point from the Mohawk River Valley, Western Oregon. In Archaeological Studies in the Willamette Valley, Oregon, edited by C. M. Aikens, pp. 549-552. University of Oregon Anthropological Papers 8, Eugene.

Alley, Richard B.

2000 The Younger Dryas Cold Interval as Viewed from Central Greenland. Quaternary Science Reviews 19:213-226.

Allison, Ira S.

1935 Glacial Erratics in Willamette Valley. Geological Society of America Bulletin 46:615-632. 
Alroy, John

1999 Putting North America's end-Pleistocene Megafaunal Extinction in Context: Large Scale Analyses of Spatial Patterns, Extinction Rates, and Size Distributions. In Extinctions in Near Time: Causes, Contexts, and Consequences, edited by R. D. E. MacPhee, pp. 105-143. Kluwer Academic/Plenum Press, New York.

Ambrose, Stanley H. 1990 Preparation and Characterization of Bone and Tooth Collagen for Isotopic Analysis. Journal of Archaeological Science 17:431-451.

Ambrose, Stanley, H., and L. Norr 1993 Experimental evidence for the relationship of the carbon isotope ratios of whole diet and dietary protein to those of bone collagen and carbonate. In Prehistoric Human Bone: Archaeology at the Molecular Level, edited by J. B. Lambert and G. Grupe, pp. 1-37. New York: Springer-Verlag.

Ambrose, Stanley H., and Michael J. DeNiro

1986 The Isotopic Ecology of East African Mammals. Oecologia 69(3):395406.

Balasse, Marie, Hervé Bocherens, and André Mariotti 1999 Intra-bone Variability of Collagen and Apatite Isotopic Composition Used as Evidence of a Change of Diet. Journal of Archaeological Science 26:593-598.

Balster, C.A., and R.B. Parsons 1968 Geomorphology and Soils, Willamette Valley, Oregon. Oregon State University Agricultural Experiment Station Special Report 265, Corvallis.

Barnosky, Anthony D.

1978 Description of Hillsboro (Oregon) Paleontological Locality (UWBM locality no. C0139). Database entry on file at the University of Washington Burke Museum.

1986 'Big Game' Extinction Caused by Late Pleistocene Climatic Change: Irish Elk (Megaloceros giganteus) in Ireland. Quaternary Research 25:128-135.

Barnosky, Anthony D., Paul L. Koch, Robert S. Feranec, Scott L. Wing, and Alan B. Shabel

2004 Assessing the Causes of Late Pleistocene Extinctions on the Continents. Science 306:70-75.

Barnosky, Cathy W.

1985 Late-Quaternary Vegetation History near Battle Ground Lake, Southern Puget Trough, Washington. Geological Society of America Bulletin 96:263-271. 
Bartelink, Eric

2006 Resource Intensification in Pre-Contact Central California: A

Bioarchaeological Perspective on Diet and Health Patterns among Hunter-

Gatherers from the Lower Sacramento Valley and San Francisco Bay.

Unpublished Ph.D. dissertation, Department of Anthropology, Texas A\&M

University, College Station, Texas.

Barton, Bax R., and Stacie J. Cearley

2008 Paleontological Investigation at the Pratum-Rutschman/Qualey Mammoth

Site, Marion County, Oregon. Current Research in the Pleistocene 25:161-163.

Barton, Miles, Nigel Bean, Stephen, Dunleavy, Ian Gray, and Adam White

2002 Prehistoric America: A Journey through the Ice Age and Beyond. Yale, New Haven.

Beck, Charlotte and George T. Jones

2010 Clovis and Western Stemmed: Population Migration and the Meeting of

Two Technologies in the Intermountain West. American Antiquity 75(1):81-116.

Behrensmeyer, Anna K.

1978 Taphonomic and Ecologic Information from Bone Weathering.

Paleobiology 4(2):150-162.

Bella, Rick

2007 This Find has Mammoth Implications. In The Oregonian, electronic document,

http://www.oregonlive.com/printer/printer.ssf?/base/metro_southwest_news/1181 456803318770.xml\&coll=7, accessed October 3, 2008.

Berger R., A.G. Horney, and W.F. Libby

1964 Radiocarbon dating of bone and shell from their organic components.

Science 144:999-1001.

Bishop, Ellen M.

2003 In Search of Ancient Oregon: A Geological and Natural History. Timber Press, Portland.

Bocherens, Hervé

2003 Isotopic Biogeochemistry and the Paleoecology of the Mammoth Steppe Fauna. In DEINSEA, edited by J. W. F. Reumer, J. D. Vos and D. Mol, pp. 57-76. vol. 9. 
Bocherens, Hervé, Alain Argant, Jacqueline Argant, Daniel Billiou, Evelyne CrégutBonnoure, Bernadette Donat-Ayache, Michel Philippe, and Michel Thinon 2004 Diet Reconstruction of Ancient Brown Bears (Ursus arctos) from Mont Ventoux (France) Using Bone Collagen Stable Isotope Biogeochemistry (13C, $15 N)$. Canadian Journal of Zoology 82:576-586.

Bocherens, Hervé, Daniel Billiou, Maryléne Patou-Mathis, Dominique Bonjean, Marcel Otte, and André Mariotti

1997 Paleobiological Implications of the Isotopic Signatures (13C, 15N) of Fossil Mammal Collagen in Scladina Cave (Sclayn, Belgium). Quaternary Research 48:370-380.

Bocherens, Hervé, Gilles Pacaud, Petr A. Lazarev, and André Mariott

1996 Stable Isotope Abundances (13C, 15N) in Collagen and Soft Tissues from Pleistocene Mammals from Yakutia: Implications for the Palaeobiology of the Mammoth Steppe. In Palaeogeography, Palaeoclimatology, Palaeoecology 126:31-44.

Bonnichsen, Robson, Michael Full, and Marvin Reken 2002 Preliminary Report of the McMinnville Mammoth, Oregon: A Taphonomic Approach. Paper presented at El Primer Simposio Internacional El Hombre Temprano en America y sus Implicaciones En el Poblamiento de la Cuenca de Mexico, Mexico D.F. Manuscript on file at the University of Oregon Museum of Natural and Cultural History under documentation for paleontological locality \#2666.

Bretz, Harlan J.

1925 The Spokane Flood beyond the Channeled Scablands. Journal of Geology 33:97-115, 236-259.

Bronk Ramsey, Christopher 2010 OxCal v4.1.5.

Brook, Barry W., and David M.J.S. Bowman 2002 Explaining the Pleistocene Megafaunal Extinctions: Models, Chronologies, and Assumptions. PNAS 99(23):14624-14627.

Brown, T.A., Nelson D.E., J.S. Vogel, and J.R. Southon 1988 Improved Collagen Extraction by Modified Longin Method. Radiocarbon 30(2):171-177.

Cannon, Michael D., and David J. Meltzer 2004 Early Paleoindian Foraging: Examining the Faunal Evidence for Large Mammal Specialization and Regional Variability in Prey Choice. Quaternary Science Reviews 23(18/19):1955-1987. 
Cearley, Stacie J.

2008 Paleontology, Geography and Biochemistry of the Pratum Mammoth, Western Oregon. Unpublished undergraduate honors thesis, Central Washington Manuscript on file at the University of Oregon Museum of Natural and Cultural History under documentation for paleontological locality \#2666, Eugene, Oregon.

Cerling, Thure E., John A. Hart, and Terese B. Hart

2004 Stable Isotope Ecology in the Ituri Forest. Oecologia 138:5-12.

Churcher, C.S., and M.C. Wilson

1990 Methods in Quaternary Ecology - Vertebrates. In Geoscience Canada17(2):59-78.

Clampet, Jennifer

2006 Tu Tu Tuala tusk and Teeth Return to Tualatin. In The Times, electronic document, http://www.tigardtimes.com/news/story.php?story_id=116188171647367300, accessed June 27, 2008.

Coltrain, Joan B., John M. Harris, Thure E. Cerling, James R. Ehleringer, Maria-Denise Dearing, Joy Ward, and Julie Allen

2004 Rancho La Brea Stable Isotope Biogeochemistry and its Implications for the Palaeoecology of the Late Pleistocene, Coastal Southern California. Palaeogeography, Palaeoclimatology, Palaeoecology 205:199-219.

Condon, Thomas

1902 The Two Islands and What Came of Them. J.K. Gill Co., Portland.

Connolly, Thomas J.

1994 Paleo Point Occurrences in the Willamette Valley, Oregon. In Contributions to the Archaeology of Oregon 1989-1994, edited by P. W. Baxter, pp. 81-88. Association of Oregon Archaeologists Occasional Papers No. 5. Association of Oregon Archaeologists, Inc., Eugene.

2003a Human Hair from Terminal Pleistocene Peat Deposits in the Willamette Valley. Current Archaeological Happenings in Oregon 28(3/4):9-15.

2003b Letter Report RE: Exploratory archaeological probing for the Oregon Highway 214 Sidewalk Construction, City of Woodburn, Marion County, Submitted to the Oregon Department of Transportation. Manuscript on file at the Oregon State Historic Preservation Office, Salem, Oregon. 
Connolly, Thomas J., Charles M. Hodges, Guy L. Tasa, and Brian L. O'Neill 1997 Cultural Chronology and Environmental History in the Willamette Valley, Oregon. Paper presented at the $50^{\text {th }}$ Annual Northwest Anthropological Conference, Ellensburg, Washington.

Cressman, L.S., and W.S. Laughlin

1941 A Probable Association of Mammoth and Artifacts in the Willamette Valley, Oregon. American Antiquity 6(4):339-342.

Cressman, Luther S.

1947 Further Information on Projectile Points from Oregon. American Antiquity 13:177-179.

Cuffey, K.M., and G.D. Clow

1997 Temperature, Accumulation, and Ice Sheet elevation in Central Greenland through the Last Deglacial Transition. Journal of Geophysical Research 102: 26,383-26,396.

Culleton, Brendan J.

2011 Bone Collagen AMS 14C Dating at University of Oregon: XAD Purification. Manuscript on file at the University of Oregon Archaeometry Facility, Department of Anthropology, University of Oregon, Eugene, Oregon.

Davis, Owen K., Larry D. Agenbroad, Paul S. Martin, and Jim I. Mead 1984 The Pleistocene Dung Blanket of Bechan Cave, Utah. In Carnegie Museum of Natural History Special Publication 8:267-282.

DeNiro, Michael J.

1985 Postmortem Preservation and Alteration of in vivo Bone Collagen Isotope Ratios in relation to Palaeodietary Reconstruction. Nature 317:806-809.

DeNiro, Michael J., and Samuel Epstein 1978 Influence of Diet on the Distribution of Carbon Isotopes in Animals. Geochimica et Cosmochimica Acta 42:495-506.

1981 Influence of Diet on the Distribution of Nitrogen Isotopes in Animals. Geochimica et Cosmochimica Acta 45(3):341-351.

Driskell, Boyce N., and Renee B. Walker 2007 Making Sense of Paleoindian Subsistence Strategies. In Foragers of the Terminal Pleistocene in North America, edited by R.B. Walker and B.N. Driskell, pp. 226-238. University of Nebraska Press, Lincoln. 
Duncan, Patrick

1992 Horses and Grasses: The Nutritional Ecology of Equids and their Impact on the Camargue. Springer-Verlag, New York.

Ehleringer, James R., and Russell K. Monson

1993 Evolutionary and Ecological Aspects of Photosynthetic Pathway

Variation. Annual Review of Ecology and Systematics 24:411-439.

Eisenmann, V., M.T. Alberdi, C. De Giuli, and U. Staesche

1988 Volume 1: Methodology. In Studying Fossil Horses: collected papers after the "New York International Hipparion Conference, 1981", edited by M.

Woodburne and P. Sondaar, pp. 1-71. Leiden: Brill.

Ellingson, David B., and Edward Byrd Davis

2009 Preliminary Report on a Pathological Bison antiquus Skeleton from

Woodburn, Oregon, Excavated as Part of a High School Curriculum. Geological Society of America Abstracts with Programs 41(7):455.

Faith, J. Tyler, and Todd A. Surovell

2009 Synchronous Extinction of North America's Pleistocene mammals. PNAS 106(49): 20641-20645.

Fiedel, Stuart

2009 Sudden Deaths: The Chronology of Terminal Pleistocene Megafaunal Extinction. In American Megafaunal Extinctions at the End of the Pleistocene, edited by G. Haynes, pp. 21-37. Springer + Business Media B.V., Berlin.

Fiedel, Stuart, and Gary Haynes

2004 A Premature Burial: Comments on Grayson and Meltzer's "Requiem for Overkill”. Journal of Archaeological Science 21:121-131.

Firestone, R.B, A. West, J.P. Kennett, L. Becker, T.E. Bunch, Z.S. Revay, P.H. Shultz, T. Belgya, D.J. Kennett, J.M. Erlandson, O.J. Dickenson, A.C. Goodyear, R.S. Harris, G.A. Howard, J.B. Kloosterman, P. Lechler, P.A. Mayewski, J. Montgomery, R. Poreda, T.

Darrah, S.S. Que Hee, A.R. Smith, A. Stich, W. Topping, J.H. Wittke, and W.S. Wolbach 2007 Evidence for an Extraterrestrial Impact 12,900 Years Ago that Contributed to the Megafaunal Extinctions and the Younger Dryas Cooling. PNAS 104(41):16016-16021.

Fisher, John W. Jr.

1995 Bone Surface Modifications in Zooarchaeology. Journal of Archaeological Method and Theory 2(1):7-68. 
France, Christine A.M., Paula M. Zelanko, Alan J. Kaufman, and Thomas R. Holtz 2007 Carbon and Nitrogen Isotopic Analysis of Pleistocene Mammals from the Saltville Quarry (Virginia, USA): Implications for Trophic Relationships. Palaeogeography, Palaeoclimatology, Palaeoecology 249:271-282.

Gannett, Marshall W., and Rodney R. Caldwell 1998 Geologic Framework of the Willamette Lowland Aquifer System, Oregon and Washington. U.S. Geological Survey Professional Paper, 1424-A.

George, John, and Ronald Sund

1962 Tualatin Mastodon. In Mastodon: The Tualatin Connection, edited by Y.S. Addington. Manuscript on file at the Tualatin Heritage Center, Tualatin, Oregon.

Gilbert, M. Thomas, Dennis L. Jenkins, Anders Gotherstrom, Nuria Naveran, Juan J. Sanchez, Michael Hofreiter, Philip Francis Thomsen, Jonas Binladen, Thomas F. G.

Higham, Robert M. Yohe II, Robert Parr, Linda Scott Cummings, and Eske Willerslev 2008 DNA from Pre-Clovis Human Coprolites in Oregon, North America. Science 320:786-788.

Glenn, Jerry L.

1965 Late Quaternary Sedimentation and Geological History of the North Willamette Valley, Oregon. Ph.D. dissertation, Oregon State University. University Microfilms, Ann Arbor.

Gobetz, Katrina E., and Steven R. Bozarth 2001 Implications for Late Pleistocene Mastodon Diet from Opal Phytoliths in Tooth Calculus. Quaternary Research 55:115-122.

Graham, Russell

1986a Appendix 2, Part 1: Taxonomy of North American Mammoths. In The Colby Mammoth Site: Taphonomy and Archaeology of a Clovis Kill in Northern Wyoming, edited by G. S. Frison and L.C. Todd, pp. 165-170. University of New Mexico Press, Albuquerque.

1986b Appendix 2, Part 2: Descriptions of the Dentitions and Stylohyoids of Mammuthus columbi from the Colby Site. In The Colby Mammoth Site:

Taphonomy and Archaeology of a Clovis Kill in Northern Wyoming, edited by G. S. Frison and L.C. Todd, pp. 171-190. University of New Mexico Press, Albuquerque.

Graham, Russell W., and Ernest L. Lundelius

1984 Coevolutionary Disequilibrium and Pleistocene Extinctions. In Quaternary Extinctions: A Prehistoric Revolution, edited by P. S. Martin and R. G. Klein, pp. 223-249. University of Arizona Press, Tucson. 
Grayson, Donald K.

1981 A Critical View of the Use of Archaeological Vertebrates in

Paleoenvironmental Reconstruction. Journal of Ethnobiology 1:28-38.

1987 An Analysis of the Chronology of Late Pleistocene Mammalian Extinctions in North America. Quaternary Research 28:281-289.

1991 Late Pleistocene Mammalian Extinction in North America: Taxonomy, Chronology, and Explanations. Journal of World Prehistory 5(3):193-229.

2000 Mammalian Responses to Middle Holocene Climatic Change in the Great Basin of the Western United States. Journal of Biogeography 27(1):181-192.

2007 Deciphering North American Pleistocene Extinctions. Journal of Anthropological Research 63:185-213.

Grayson, Donald K., and David J. Meltzer 2002 Clovis Hunting and Large Mammal Extinction: A Critical Review of the Evidence. Journal of World Prehistory 16(4):313-359.

2003 A Requiem for North American overkill. Journal of Archaeological Science 30:585-593.

Grigg, Laurie D., and Cathy Whitlock

1998 Late-Glacial Vegetation and Climate Change in Western Oregon. Quaternary Research 49:287-298.

Gröcke, Darren R., Hervé Bocherens, and André Mariotti 1997 Annual Rainfall and nitrogen-Isotope Correlation in Macropod Collagen: Application as a Paleoprecipitation Indicator. Earth and Planetary Science Letters 153:279-285.

Grootes, P. M., M. Stuiver, J. W. C. White, S. Johnsen, and J. Jouzel 1993 Comparison of Oxygen Isotope Records from the GISP2 and GRIP Greenland Ice Cores. Nature 366:552-554.

Gustafson, Carl E., Delbert Gilbow, and Richard D. Daugherty 1979 The Manis Mastodon Site: Early Man on the Olympic Peninsula. Canadian Journal of Archaeology 3:157-164.

Guthrie, R. Dale

1968 Paleoecology of the Large-Mammal Community in Interior Alaska during the Late Pleistocene. American Midland Naturalist 79(2):346-363.

1984 Mosaics, Allelochemics, and nutrients: an ecological Theory of Late Pleistocene Megafaunal Extinctions. In Quaternary Extinctions: a Prehistoric 
Revolution, edited by P. S. Martin and R. G. Klein, pp. 259-298. University of Arizona Press, Tucson.

1990 Frozen Fauna of the Mammoth Steppe: The Story of Blue Babe. University of Chicago Press, Chicago.

2006 New Carbon Dates Link Climatic Change with Human Colonization and Pleistocene Extinctions. Nature 441:207-209.

Hansen, Henry P., and E.L. Packard

1949 Pollen Analysis and the Age of Proboscidian Bones near Silverton, Oregon. Ecology 30(4):461-468.

Hansen, Richard M.

1980 Late Pleistocene Plant Fragments in the Dungs of Herbivores at Cowboy

Cave. In Cowboy Cave, edited by J. D. Jennings, pp. 179-184. vol. 104, University of Utah Anthropological Papers.

Hay, Oliver P.

1927 The Pleistocene of the Western Region of North America and Its Vertebrated Animals, publication No. 322 B. Carnegie Institution of Washington, Washington D.C.

Haynes, Gary

1991 Mammoths, Mastodonts, and Elephants. Cambridge University Press, New York.

2002 The Catastrophic Extinction of North American Mammoths and Mastodonts. In World Archaeology 33(3):391-416.

2007 A Review of Some Attacks on the Overkill Hypothesis, with Special Attention to Misrepresentations and Doubletalk. Quaternary International 169170:84-94.

2009 Introduction to the Volume. In American Megafaunal Extinctions at the End of the Pleistocene, edited by G. Haynes, pp. 1-20. Springer + Business Media B.V., Berlin.

Haynes, Gary, and J. Klimowicz 2003 Mammoth (Mammuthus spp.) and American Mastodont (Mammut americanum) Bonesites: What do the Differences Mean? . In DEINSEA, edited by J. W. F. Reumer, J. D. Vos and D. Mol, pp. 185-204. vol. 9. 
Heaton, T.H.E., J.C. Vogel, J.C., G. von la Chevalerie, G. Collett 1986 Climatic Influence on the Isotopic Composition of Bone Nitrogen. Nature 322:822-823.

Heinz, Fred

1971 Another Clovis Point. Screenings 20(7):3.

Higham, T.F.G., R.M. Jacobi, and C. Bronk Ramsey 2006 Radiocarbon Dating Of Ancient Bone Using Ultrafiltration. Radiocarbon 48(2):179-195.

Hill, Christopher L., John P. Albanese, Robert G. Dundas, Leslie B. Davis, David C. Batten, Dale P. Herbort, James K. Huber, Susan C. Mulholland, James K. Feathers, and Matthew J. Root 2005 The Merrell Locality (24BEI659) and Centennial Valley, Southwest Montana: Pleistocene Geology, Paleontology, and Prehistoric Archaeology. Museum of the Rockies, Montana State University, Bozeman.

Hoffman, R.R., and D.R.M. Stewart 1972 Grazer or Browser: A Classification Based on the Stomach Structure and feeding Habits of East African Ruminants. Mammalia 36:226-240.

Hoppe, Kathryn A., and Paul L. Koch 2006 The Biogeochemistry of the Aucilla River Fauna. In The First Floridians and Last Mastodons: the Page-Ladson Site in the Aucilla River, edited by S. D. Webb, pp. 343-378. Springer, the Netherlands.

Jackson, S. T., D. R. Whitehead, and G. D. Ellis 1986 Late-glacial and early Holocene vegetational history at the Kolarik mastodon site, northwestern Indiana. The American Midland Naturalist 115(2):361-373.

Jenkins, Dennis L., Thomas J. Connolly, and C. Melvin Aikens 2004 Early and Middle Holocene Archaeology in the Northern Great Basin: Dynamic Natural and Cultural Ecologies. In Early and Middle Holocene Archaeology of the Northern Great Basin, edited by D. L. Jenkins, T. J. Connolly, and C. M. Aikens, pp. 1-20. University of Oregon Anthropological Papers No. 62.

Kapp, R.O.

1986 Late-glacial pollen and macrofossils associated with the Rappuhn Mastodont (Lapeer County, Michigan). American Midland Naturalist 116:368377. 
Keefer, Lindsay

2010 The Nine-foot Jigsaw Puzzle: Woodburn Student Pieces Together Bison Remains, Estimated at 12,000 Years Old. Woodburn Independent 29 April 2010, Woodburn, Oregon.

Kelly, Robert L., and Lawrence C. Todd 1988 Coming into the Country: Early Paleoindian Hunting and Mobility. American Antiquity 53(2):231-244.

Kennett, Douglas J., Brendan J. Culleton, Barbara Voorhies, and John R. Southon 2011 Bayesian Analysis of High Precision AMS 14C Dates from a Prehistoric Mexican Shellmound. In press, Radiocarbon.

Kennett, D.J., J.P. Kennett, G.J. West, J.M. Erlandson, J.R. Johnson, I.L. Hendy, A. West, B.J. Culleton, T.L. Jones, Thomas W. Stafford, Jr. 2008 Wildfire and abrupt ecosystem disruption on California's Northern Channel Islands at the Ållerød-Younger Dryas boundary (13.0-12.9 ka). Quaternary Science Reviews 27:2528-2543.

Kiltie, Richard A. 1984 Seasonality, Gestation Time, and Large Mammal Extinctions. In Quaternary Extinctions: a Prehistoric Revolution, edited by P. S. Martin and R. G. Klein, pp. 299-314. University of Arizona Press, Tucson.

King, James E., and Jeffrey J. Saunders 1984 Environmental Insularity and the Extinction of the American Mastodont. In Quaternary Extinctions: a Prehistoric Revolution, edited by P. S. Martin and R. G. Klein, pp. 315-339. University of Arizona Press, Tucson.

Kittleman, Laurence R. 1975 Letter to David S. Webb dated November 20, 1975 (RE: UO paleontological locality \#2666). Document on file at the University of Oregon Museum of Natural and Cultural History, Eugene, Oregon.

1976a Application for Faculty Research Award. Submitted to the Graduate School of the University of Oregon (RE: UO paleontological locality \#2666). Document on file at the University of Oregon Museum of Natural and Cultural History, Eugene, Oregon.

1976b Letter to C.M. Aikens dated August 7, 1976 (RE: UO paleontological locality \#2666). Document on file at the University of Oregon Museum of Natural and Cultural History, Eugene, Oregon. 
1976c Radiocarbon Sample Submission Sheets for the Radiocarbon Dating Laboratory at Washington State University (RE: UO paleontological locality \#2666). Document on file at the University of Oregon Museum of Natural and Cultural History, Eugene, Oregon.

1976d Letter to Donald K. Grayson dated August 25, 1976 (RE: UO paleontological locality \#2666). Document on file at the University of Oregon Museum of Natural and Cultural History, Eugene, Oregon.

1977 Miscellaneous documents RE: UO paleontological locality \#2666. Manuscript on file at the University of Oregon Museum of Natural and Cultural History, Eugene, Oregon.

Koch, Paul L.

1998 Isotopic Reconstruction of Past Continental Environments. Annual Review of Earth and Planetary Sciences 26:573-613.

Koch, Paul L., and Anthony D. Barnosky 2006 Late Quaternary Extinctions: State of the Debate. Annual Review of Ecology, Evolution, \& Systematics 37(1):215-250.

Koch, Paul L., Kathryn A. Hoppe, and S. David Webb 1998 The Isotopic Ecology of Late Pleistocene Mammals in North America: Part 1. Florida. Chemical Geology 152(1998):119-138.

Kurtén, Björn, and Elaine Anderson 1980 Pleistocene mammals of North America. Columbia University Press, New York.

Laub, R. S.

1996 The Masticatory Apparatus of the American Mastodon (Mammut americanum). In Paleoecology and Paleoenvironments of Late Cenozoic Mammals: Tributes to the Career of C.S. (Rufus) Churcher, edited by K. M. Stewart and K. L. Seymour, pp. 375-405. University of Toronto Press, Toronto.

Linder, Robert

1992 The Tualatin Mastodon. In Mastodon: The Tualatin Connection, edited by Y.S. Addington. Manuscript on file at the Tualatin Heritage Center, Tualatin, Oregon.

Longin, R.

1971. New method of collagen extraction for radiocarbon dating. Nature 230:241-242. 
Lundelius, Ernest Jr.

1964 The Use of Vertebrates in Paleoecological Reconstructions. In The

Reconstruction of Past Environments, edited by Hester JJ and J. Schoenwetter.

Fort Burgwin Research Center Publication 3, Taos.

Lyman, R. Lee

1994 Vertebrate Taphonomy. Cambridge University Press, Cambridge.

2008 Quantitative Paleozoology. Cambridge University Press, Cambridge.

Lysek, Carol A.

1999 Amateur Paleontologist Uncovers Oregon Mammoths. Mammoth Trumpet 14(2):14-16.

MacFadden, Bruce J.

1992 Fossil Horses: Systematics, Paleobiology, and Evolution of the Family

Equidae. Cambridge University Press, New York.

MacFadden, Bruce J., Thure E. Cerling, John M. Harris, and Jose Prado 1999 Ancient Latitudinal Gradients of C3/C4 Grasses Interpreted from Stable Isotopes of New World Pleistocene Horse (Equus) Teeth. Global Ecology and Biogeography 8:137-149.

MacPhee, Ross D., and Preston A. Marx

1997 The 40,000 Year Plague: Humans, Hyperdisease, and First-contact Extinctions. In Natural change and human impact in Madagascar, edited by S. M. Goodman and B. D. Patterson, pp. 169-217. Smithsonian Inst. Press, Washington, D.C.

Madden, Cary T.

1995 Even more earliest isotopically dated Maтmuthus from North America. Quaternary Research 43:265-267.

Manzano, Phil

2007 Old Tooth Takes Boys from Mac Town to Tinseltown. The Oregonian, electronic document, http://blog.oregonlive.com/breakingnews/2007/06/old_tooth_takes_boys_from_m ac.html, accessed January 25, 2010.

Marlon, J. R., P. J. Bartlein, M. K. Walsh, S. P. Harrison, K. J. Brown, M. E. Edwards, P. E. Higuera, M. J. Power, R. S. Anderson, C. Briles, A. Brunelle, C. Carcaillet, M. Daniels, F. S. Hu, M. Lavoie, C. Long, T. Minckley, P. J. H. Richard, A. C. Scott, D. S. Shafer, W. Tinner, Jr. C. E. Umbanhowar, and C. Whitlock 2009 Wildfire Responses to Abrupt Climate Change in North America. PNAS 106(8):2519-2524. 
Martin, Paul S.

1967 Prehistoric Overkill. In Pleistocene extinctions: The search for a cause, edited by P. S. Martin and H. E. Wright, pp. 75-120. Yale University Press, New Haven.

1973 The Discovery of America. Science 179(4077):969-974.

1984a Catastrophic Extinctions and Late Pleistocene Blitzkrieg: Two Radiocarbon Tests. In Extinctions, edited by M. H. Nitecki, pp. 153-189. University of Chicago Press, Chicago.

1984b Prehistoric Overkill: The Global Model. In Quaternary Extinctions: A Prehistoric Revolution, edited by P. S. Martin and R. G. Klein, pp. 354-403. University of Arizona Press, Tucson.

2005 Twilight of the Mammoths: Ice Age Extinction and the Rewilding of America. University of California Press, Berkeley.

Martin, Paul S., and Richard G. Klein (editors)

1984 Quaternary Extinctions: A Prehistoric Revolution. University of Arizona Press, Tucson.

McCornack, Ellen C.

1914 A Study of Oregon Pleistocene. University of Oregon Bulletin, N.S. 12(2):2-16.

1920 Contributions to the Pleistocene History of Oregon. University of Oregon Leaflet Series Geology Bulletin 6(3, Part 2):1-22.

McDonald, H. Gregory, Larry D. Agenbroad, and Carol Manganaro Haden 2004 Late Pleistocene Mylodont Sloth Paramylodon harlani (Mammalia: Xenarthra) from Arizona. The Southwestern Naturalist 49(2):229-238.

McDonald, H. Gregory, and Steve Pelikan

2006 Mammoths and Mylodonts: Exotic Species from Two Different Continents in North American Pleistocene Faunas. Quaternary International 142143:229-241.

McDonald, Jerry N.

1981 North American Bison: their Classification and Evolution. University of California Press, Berkeley. 
McFarlane, Donald A.

1999 A comparison of methods for the probabilistic determination of vertebrate extinction chronologies. In Extinctions in Near Time: Causes, Contexts, and Consequences, edited by R. D. E. MacPhee, pp. 95-106. Plenum Press, New York.

Mead, Jim I., Larry D. Agenbroad, Owen K. Davis, and Paul S. Martin

1986 Dung of Mammuthus in the Arid Southwest, North America. Quaternary Research 25:121-127.

Mead, Jim I., C. Vance Haynes, and Bruce B. Huckell 1979 A Late Pleistocene Mastodon (Mammut americanum) from the Lehner Site, Southeastern Arizona. The Southwestern Naturalist 24(2):231-238.

Meltzer, David J., and Vance T. Holliday 2010 Would North American Paleoindians have Noticed Younger Dryas Age Climate Changes? Journal of World Prehistory 23:1-41.

Minagawa, Masao, and Eitaro Wada

1984 Stepwise Enrichment of 15N Along Food Chains: Further Evidence and the Relation between $\delta 15 \mathrm{~N}$ and Animal Age. Geochimica et Cosmochimica Acta 48:1135-1140.

Minervini, J.M., J.E. O'Connor, and R.E. Wells 2003 Maps Showing Inundation Depths, Ice-Rafted Erratics, and Sedimentary Facies of Late Pleistocene Missoula Floods in the Willamette Valley, Oregon. U.S. Geological Survey Open-File Report 03-408. Electronic document, http://pubs.usgs.gov/of/2003/of03-408/, accessed August 1, 2011.

Minor, Rick

1985 Paleo-Indians in Western Oregon: A Description of Two Fluted Projectile Points. Northwest Anthropological Research Notes 19(1):33-40.

Mossiman, J.E., and Paul S. Martin 1975 Simulating Pleistocene overkill by Palaeo-Indians. American Scientist 63(3):304-313.

Naples, Virginia L.

1989 The Feeding Mechanism in the Pleistocene Ground Sloth, Glossotherium. Natural History Museum of Los Angeles County Contributions in Science 415:123. 
Newsom, Lee A., and Matthew C. Mihlbachler

2006 Mastodon (Mammut americanum) Diet and Foraging Patterns based on Dung Material from the Page/Ladson Site (8JE581), Jefferson County, Florida. In The First Floridians and Last Mastodons: the Page-Ladson Site in the Aucilla River, edited by S. D. Webb, pp. 263-333. Springer, the Netherlands.

NRCS

2010 National Resources Conservation Service's Web Soil Survey. Electronic document, http://websoilsurvey.nrcs.usda.gov/app/HomePage.htm, accessed May 2,2010 .

O'Connell, Sanjida 2002 Archaeologists Split Hairs over First Arrivals. The Guardian, electronic document, http://www.guardian.co.uk/science/2002/oct/17/science.artsandhumanities, accessed September 13, 2010.

O'Connor, Jim E. and Gerardo Benito

2009 Late Pleistocene Missoula Floods: 15,000-20,000 Calendar Years before Present from Radiocarbon Dating. Geological Society of America Abstracts with Programs 41(7):169.

O'Connor, Jim, Andrei Sarna-Wojcicki, Karl C. Wozniak, Danial J. Polette, and Robert J. Fleck

2001 Origin, Extent, and Thickness of Quaternary Geologic Units in the Willamette Valley, Oregon. U.S. Geological Survey Professional Paper 1620, Reston, VA.

O’Grady, Patrick, Scott P. Thomas, and Michael F. Rondeau 2008 The Sage Hen Gap Fluted-Point Site, Harney County, Oregon. Current Research in the Pleistocene 25:127-129.

2009 Recent Fluted-Point Finds in Eastern Oregon. Current Research in the Pleistocene 26:100-102.

O'Leary, Marion H.

1988 Carbon Isotopes in Photosynthesis. BioScience 38:328-336.

Olsen, Stanley J.

1972 Osteology for the Archaeologist: the American Mastodon and the Woolly Mammoth. Papers of the Peabody Museum of Archaeology and Ethnology, Harvard University, 56(3):1-45. 
Oregon History Project

2010 Discovery of Mastodon Remains near Dayton. Electronic document, http://www.ohs.org/education/oregonhistory/historical_records/dspDocument.cfm ?doc_ID=95B20FCF-A01E-5813-43C3372FF76325BB, accessed January 25, 2010.

Orr, Elizabeth L., and William N. Orr 2009 Oregon Fossils. $2^{\text {nd }}$ ed. Oregon State University Press, Corvallis, Oregon.

Orr, Elizabeth, William N. Orr, and Ewart M. Baldwin 1992 Geology of Oregon. $4^{\text {th }}$ ed. Kendall/Hunt Publishing Company, Dubuque, Iowa.

Orr, William N., and Elizabeth L. Orr 1981 Handbook of Oregon Plant and Animal Fossils. William N. Orr, Eugene, Oregon.

Owaga, Mary L.

1975 The Feeding Ecology of Wildebeest and Zebra in Athi-Kaputei Plains. Journal of African Ecology 13:375-383.

Owen-Smith, Norman

1987 Pleistocene Extinctions: The Pivotal Role of Megaherbivores.

Paleobiology 13(3):351-362.

Ozbun, Terry, Eric Forgeng, and Dan Stueber 1997 The Circumstantial Evidence for Clovis Occupation of Western Oregon. Paper presented at the fall meeting of the Association of Oregon Archaeologists, Jacksonville, Oregon.

Paquay, Francois S., Steven Goderis, Greg Ravizza, Frank Vanhaeck, Matthew Boyd, Todd A. Surovell, Vance T. Holliday, Jr. C. Vance Haynes, and Philippe Claeys 2009 Absence of Geochemical Evidence for an Impact Event at the BøllingAllerød/Younger Dryas Transition. PNAS 106(51):21505-21510.

Pearl, Christopher A.

1999 Holocene Environmental History of the Willamette Valley, Oregon: Insights from an 11,000-Year Record from Beaver Lake. Unpublished master's thesis, Environmental Studies Program, University of Oregon, Eugene, Oregon.

Perkins, H.C.

1842 Notice of Fossil Bones from Oregon Territory in a letter to Dr. C. T. Jackson. American Journal of Science and Arts 42(1):136-140. 
Personius, Stephen F., Harvey M. Kelsey, and Paul C. Grabau 1993 Evidence for Regional Stream Aggradation in the Central Oregon Coast Range during the Pleistocene-Holocene Transition. Quaternary Research 40:297308 .

Petersen, Kenneth L., Peter J. Mehringer Jr., and Carl E. Gustafson 1983 Late-glacial Vegetation and Climate at the Manis Mastodon Site, Olympic Peninsula, Washington. Quaternary Research 20:215-231.

Pinson, Ariane O.

2011 The Clovis Occupation of the Dietz Site (35lk1529), Lake County, Oregon, and its Bearing on the Adaptive Design of Clovis Foragers. American Antiquity 76(2):285-314.

Reese, Jo and John L. Fagan

1997 An Early-Holocene Archaeological Site in Oregon's Willamette Valley. Current Research in the Pleistocene 14:77-78.

Reimer, P. J., Baillie M. G. L., E. Bard, A. Bayliss, J.W. Beck, P.G. Blackwell, C. Bronk Ramsey, C.E. Buck, G.S. Bur, R.L. Edwards, M. Friedrich, P.M. Grootes, T.P. Guilderson, I. Hajdas, T.J. Heaton, A.G. Hogg, K.A. Hughen, K.F. Kaiser, B. Kromer, F.G. McCormac, S.W. Manning, R.W. Reimer, D.A. Richards, J.R. Southon, S. Talamo, C.S.M. Turney, J. van der Plicht, and C.E. Weyhenmeyer 2009 IntCal09 and Marine09 Radiocarbon Age Calibration Curves, 0-50,000 years cal BP. Radiocarbon 51(4):1111-1150.

Rivals, Florent, Nikos Solounias, and Matthew C. Mihlbachler 2007 Evidence for Geographic Variation in the Diets of Late Pleistocene and Early Holocene Bison in North America, and Differences from the Diets of Recent Bison. Quaternary Research 68:338-346.

Ruez, Dennis R. Jr.

2005 Diet of Pleistocene Paramylodon Harlani (Xenarthra: Mylodontidae): Review of Methods and Preliminary Use of Carbon Isotopes. Texas Journal of Science 57(4):329-344.

Santos, G.M., J.R. Southon, K.C. Druffel-Rodriguez, S. Griffin, and M. Mazon 2004 Magnesium perchlorate as an alternative water trap in AMS graphite sample preparation: a report on sample preparation at the KCCAMS Facility at the University of California, Irvine. Radiocarbon 46(1):165-173.

Saunders, Jeffrey J.

1996 North American mammutidae. In The Proboscidea: Evolution and Paleoecology of Elephants and Their Relatives, edited by J. Shoshani and P. Tassy, pp. 271-279. Oxford University Press, Oxford 
Schoeninger, Margaret J., and Michael J. DeNiro

1984 Nitrogen and Carbon Isotopic Composition of Bone Collagen from Marine and Terrestrial Animals. Geochimica et Cosmochimica Acta 48(4):625-639.

Schoeninger, Margaret J., Katherin M. Moore, Matthew L. Murray, and John D. Kingston 1989 Detection of Bone Preservation in Archaeological and Fossil Samples. Applied Geochemistry 4:281-292.

Scott, Eric

2006 Extinct horses and their relatives. In Fossil Treasures of the Anza-Borrego Desert: the Last Seven Million Years, edited by G. T. Jefferson and L. Lindsey, pp. 253-271. Sunbelt, San Diego.

2010 Extinctions, Scenarios, and Assumptions: Changes in Latest Pleistocene Large Herbivore Abundance and Distribution in Western North America. Quaternary International 217:225-239.

Scott, Eric, and Shelly M. Cox 2008 Late Pleistocene Distribution of Bison (Mammalia; Artiodactyla) in the Mojave Desert of Southern California and Nevada. In Geology and Vertebrate Paleontology of Western and Southern North America, edited by X. Wang and L. G. Barnes. Natural History Museum of Los Angeles County Science Series, 41.

Sealy, Judith C., Nikolaas J. van der Merwe, Julia A. Lee Thorp, and John L. Lanham 1987 Nitrogen Isotopic Ecology in Southern Africa: Implications for Environmental and Dietary Tracing. Geochimica et Cosmochimica Acta 51:27072717.

Shapiro, Beth, Alexei J. Drummond, Andrew Rambaut, Michael C. Wilson, Paul E. Matheus, Andrei V. Sher, Oliver G. Pybus, M. Thomas P. Gilbert, Ian Barnes, Jonas Binladen, Eske Willerslev, Anders J. Hansen, Gennady F. Baryshnikov, James A. Burns, Sergei Davydov, Jonathan C. Driver, Duane G. Froese, C. Richard Harington, Grant Keddie, Pavel Kosintsev, Michael L. Kunz, Larry D. Martin, Robert O. Stephenson, John Storer, Richard Tedford, Sergei Zimov, and Alan Cooper 2004 Rise and Fall of the Beringian Steppe Bison. Science 306(5701):15611565 .

Sheppard, John C.

1977 Radiocarbon Sample Reporting Sheet (RE: UO paleontological locality \#2666). Document on file at the University of Oregon Museum of Natural and Cultural History, Eugene, Oregon. 
Sherman, Barbara

2006 Tigard's 'fossil boy' MacKenzie Smith participates in real dig. In The Times, electronic document,

http://www.tualatintimes.com/news/story.php?story_id=115411947920134300, accessed March 10, 2008.

Shotwell, J. Arnold

1955 An Approach to the Paleoecology of Mammals. Ecology 36(2):327-337.

Skinner, M.F., and Kaisen, O.C.

1947 The fossil Bison of Alaska and preliminary revision of the genus. Bulletin of the American Museum of Natural History 89: 123-256.

Smith, Bruce N., and Samuel Epstein 1971 Two Categories of 13C/12C Ratios for Higher Plants. Plant Physiology 47:380-384.

Stafford, Thomas W. Jr., Kalus Brendel, and Raymond C. Duhamel 1988 Radiocarbon, ${ }^{13} \mathrm{C}$ and ${ }^{15} \mathrm{~N}$ Analysis of Fossil Bone: Removal of Humates with XAD-2 Resin. Geochimica et Cosmochimica Acta 52:2257-2267.

Stafford, Thomas W. Jr., P.E. Hare, Lloyd A. Currie, A.J. Tim Jull, and Douglas Donahue

1991 Accelerator Radiocarbon Dating at the Molecular Level. Journal of Archaeological Science 18:35-72.

Stenger, Alison T. 1996 Mammoth Park Paleo-Archaeological Project, Woodburn High School. Manuscript on file at the University of Oregon Museum of Natural and Cultural History, Eugene, Oregon.

1999 Woodburn Radiocarbon Dates. Manuscript on file at the University of Oregon Museum of Natural and Cultural History, Eugene, Oregon.

2000a Woodburn Paleoarchaeological Project Interim Report, Fieldwork 1999. Submitted to the City of Woodburn. Manuscript on file at the University of Oregon Museum of Natural and Cultural History, Eugene, Oregon.

2000b Woodburn Paleoarchaeological Project Interim Report, Legion Park 2000, Quarterly Report \#1. Submitted to the City of Woodburn. Manuscript on file at the University of Oregon Museum of Natural and Cultural History, Eugene, Oregon. 
2001 Woodburn Paleoarchaeological Project Interim Report, Legion Park 2001, Quarterly Report \#1. Submitted to the City of Woodburn. Manuscript on file at the University of Oregon Museum of Natural and Cultural History, Eugene, Oregon.

2002a Temporal Association of Paleontological and Archaeological Resources in Woodburn, ca. 12,000 BP: A Preliminary Report. Current Archaeological Happenings in Oregon 27(3/4):12-17.

2002b Woodburn Paleoarchaeological Project Interim Report, Hermanson III 2002, Quarterly Report \#1. Submitted to the City of Woodburn. Manuscript on file at the University of Oregon Museum of Natural and Cultural History, Eugene, Oregon.

2003 Woodburn Paleoarchaeological Project Interim Report, Legion Park and Van Valkenberg, Testing Program 2003, Quarterly Report \#1. Submitted to the City of Woodburn. Manuscript on file at the University of Oregon Museum of Natural and Cultural History, Eugene, Oregon.

2004 Woodburn Paleoarchaeological Project Interim Report, Van Valkenberg, Testing Program 2004, Quarterly Report \#1. Submitted to the City of Woodburn. Manuscript on file at the University of Oregon Museum of Natural and Cultural History, Eugene, Oregon.

2005 Woodburn Paleoarchaeological Project Interim Report, Legion Park (North), Testing Program 2005, Quarterly Report \#1. Submitted to the City of Woodburn. Manuscript on file at the University of Oregon Museum of Natural and Cultural History, Eugene, Oregon.

2006 Woodburn Paleoarchaeological Project, Legion Park, Testing Program 2006. Submitted to the City of Woodburn. Manuscript on file at the University of Oregon Museum of Natural and Cultural History, Eugene, Oregon.

2010a McMinnville Mammoth Site (Site \#3076) Summary of Preliminary Findings II. Submitted to the City of McMinnville. Manuscript on file at the University of Oregon Museum of Natural and Cultural History, Eugene, Oregon.

2010b Pre-Clovis in the Willamette Valley. Current Archaeological Happenings in Oregon 34(4):6-10.

Stenger, Alison T., and Mark P. Fitzsimons 2007 McMinnville Mammoth Site (Site \#3076): Summary of Preliminary Findings. Submitted to the City of McMinnville. Manuscript on file at the University of Oregon Museum of Natural and Cultural History under documentation for paleontological locality \#2666. 
Stock, Chester

1925 Cenozoic Gravigrade Edentates of Western North America, with Special Reference to the Pleistocene Megalonychidae and Mylodontidae of Rancho La Brea. Carnegie Institution of Washington, Washington.

Stuiver M. and H.A. Polach 1977 Discussion: reporting of ${ }^{14} \mathrm{C}$ data. Radiocarbon 19(3):355-363.

Stuiver, Minze, and Pieter M. Grootes 2000 GISP2 oxygen isotope ratios. Quaternary Research 53:277-284.

Surovell, Todd A., Vance T. Holliday, Joseph A. M. Gingerich, Caroline Ketron, Jr. C. Vance Haynes, Ilene Hilman, Daniel P. Wagner, Eileen Johnson, and Philippe Claeys. 2009 An Independent Evaluation of the Younger Dryas Extraterrestrial Impact Hypothesis. PNAS 106(43):18155-18158.

Szpak, Paul, Darren R. Gröcke, Regis Debruyne, Ross D.E. MacPhee, R. Dale Guthrie, Duane Froese, Grant D. Zazula, William P. Patterson, and Hendrik N. Poinar 2010 Regional Differences in Bone Collagen $\delta 13 \mathrm{C}$ and $\delta 15 \mathrm{~N}$ of Pleistocene Mammoths: Implications for Paleoecology of the Mammoth Steppe. Palaeogeography, Palaeoclimatology, Palaeoecology 286: 88-96.

Stuiver, Minze and Henry A. Poalch

1977 Reporting of ${ }^{14}$ C Data. Radiocarbon 19(3):355-363.

Taylor, R.E.

1992 Radiocarbon Dating of Bone: to Collagen and Beyond. In Radiocarbon Dating After Four Decades, edited by R. E. Taylor, A. Long and R. S. Kra, pp. 375-402. Springer, Berlin.

The Silverton Appeal

1967 Did these Giant Bones Come from... One of These? The Silverton Appeal, 31 August 1967:1. Silverton, Oregon.

The Times

2010 Giant Sloth Roamed Tualatin. In The Times, electronic document, http://www.tigardtimes.com/news/story_2nd.php?story_id=126767206524479800 \#comment_section_container, accessed march 4, 2010.

Thomas, Scott P., Patrick O'Grady, Dianne Ness, and Daniel Braden 2008 Recent Fluted-Point Finds at Lake on the Trail, Harney County, Oregon. Current Research in the Pleistocene 25:150-151. 
Tobien, $\mathrm{H}$.

1996 Evolution of zigodonts with emphasis on dentition. In The Proboscidea: evolution and palaeoecology of elephants and their relatives, edited by $\mathrm{J}$.

Shoshani \& P. Tassy, pp. 76-85. Oxford: Oxford University Press.

Ukkonen, P., L. Arppe, M. Houmark-Nielsen, K.H. Kjaer, and J.A. Karhu 2007 MIS 3 Mammoth Remains from Sweden-Implications for faunal History, Palaeoclimate and Glaciation Chronology. Quaternary Science Reviews 26:30813098.

UO MNCH Database

2009 University of Oregon Museum of Natural and Cultural History Fossil Database. Electronic database accessed October 14, 2009.

Vacco, David A., Peter U. Clark, Alan C. Mix, Hai Cheng, and R. Lawrence Edwards 2005 A Speleothem Record of Younger Dryas Cooling, Klamath Mountains, Oregon, USA. Quaternary Research 64:249-256.

van der Merwe, Nikolaas J.

1982 Carbon Isotopes, Photosynthesis and Archaeology. American Scientist 70(6):596-606.

van der Merwe, Nikolaas J., and Ernesto Medina

1991 The Canopy Effect, Carbon Isotope Ratios and Foodwebs in Amazonia. Journal of Archaeological Science 18:249-259.

van Klinken, G.J.

1999 Bone Collagen Quality Indicators for Palaeodietary and Radiocarbon Measurements. Journal of Archaeological Science 26:687-695.

Verts, B. J., and Leslie N. Carraway

1998 Land Mammals of Oregon. University of California Press, Berkeley.

Viau, A., and K. Gajewski

2007 Comments on: 'The Magnitudes of Millennial- and Orbital Scale Climatic Change in Eastern North America during the Late Quaternary' by Shuman et al. Quaternary Science Reviews 26:264-267.

von den Driesch, Angela

1976 A Guide to the Measurement of Animal Bones from Archaeological Sites. Peabody Museum Bulletin 1. Peabody Museum of Archaeology and Ethnology, Harvard University, Cambridge.

Waguespack, Nicole M., and Todd A. Surovell 2003 Clovis Hunting Strategies, or How to Make Out on Plentiful Resources. American Antiquity 68(2):333-352. 
Waitt, Richard B.

1980 About 40 Last-glacial Lake Missoula Jokulhlaups through Southern Washington. Journal of Geology 88:653-679.

1985 Case for Periodic, Colossal Jökulhlaups from Pleistocene Glacial Lake Missoula. Geological Society of America Bulletin 96:1271-1286.

Walsh, Megan K., Cathy Whitlock, and Patrick J. Bartlein 2008 14,300-year-long Record of Fire-Vegetation-Climate Linkages at Battle Ground Lake, Southwestern Washington. Quaternary Research 70:251-264.

Walsh, Megan K., Christopher A. Pearl, Cathy Whitlock, Patrick J. Bartlein, and Marc A. Worona

2010 An 11,000-year-long Record of Fire and vegetation History at Beaver Lake, Oregon, Central Willamette Valley. Quaternary Science Reviews 29:10931106.

Wampler, Peter J.

2004 Contrasting Geomorphic Responses to Climatic, Anthropogenic, and Fluvial Change Across Modern to Millennial Time Scales, Clackamas River, Oregon. Ph.D. dissertation, Oregon State University. University Microfilms, Ann Arbor.

Waters, Michael R., and Thomas W. Stafford Jr.

2007 Redefining the Age of Clovis: Implications for the Peopling of the Americas. Science 315:1122-1126.

Webb, David S.

1975 Letter to Laurence R. Kittleman dated December 8, 1975 (RE: UO paleontological locality \#2666). Document on file at the University of Oregon Museum of Natural and Cultural History.

1992 A Brief History of New World Proboscidea with Emphasis on their Adaptations and Interactions with Man. In Proboscidean and Paleoindian Interactions, edited by J. W. Fox, C. B. Smith and K. T. Wilkins, pp. 15-34. Baylor University Press, Waco.

Webb, S. David, James Dunbar, and Lee Newsom 1992 Mastodon Digesta from North Florida. Current Research in the Pleistocene 9:114-116.

White, John R.

1979 A Chronology of Upper Willamette Valley, Oregon, Prehistory. American Antiquity 44(3):556-568. 
Wilkes, Charles

1844 Narrative of the United States Exploring Expedition During the Years 1838, 1839, 1840, 1841, 1842, volume 4. C. Sherman, Philadelphia.

Willig, Judith A.

1989 Paleo-Archaic Broad Spectrum Adaptations at the Pleistocene-Holocene Boundary in Far Western North America. Ph.D. dissertation, Department of Anthropology, University of Oregon, Eugene, Oregon.

Willig, Judith A., and C. Melvin Aikens

1988 The Clovis-Archaic Interface in Far Western North America. In Early

Human Occupation in Far Western North America: The Clovis-Archaic Interface, edited by J. A. Willig, C. M. Aikens and J. L. Fagan. Nevada State Museum Anthropological Papers Number 21, Carson City.

Worona, Marc A., and Cathy Whitlock

1995 Late Quaternary Vegetation and Climate History near Little Lake, Central Coast Range, Oregon. Geological Society of America Bulletin 107(7):867-876.

Yamhill River Pleistocene Project

2010 website, http://www.yamhillriverpleistocene.com/, accessed October 1, 2010.

Yokoyama, Yusuke, Kurt Lambeck, Patrick De Deckker, Paul Johnston, and L. Keith Fifield

2000 Timing of the Last Glacial Maximum from Observed Sea-level Minima. Nature 406:713-716. 
APPENDIX A: Synthesis of Records of Extinct Mammalian Herbivores Reported from the Willamette Valley

Table A-1 is a synthesis of all the remains of extinct mammalian herbivores reported in the Willamette Valley, in either a gray literature report, published article, or this thesis. This catalogue does not include any reports publicized by private websites or the media, whether the medium be print, television, or electronic.

As stated in Chapter 6, there are several concerns with the reported finds of megafauna in the Willamette Valley. Most were first noted in the early $20^{\text {th }}$ century (Hay 1927; McCornack 1914). Many of these were in private collections that have long since disappeared. None of the materials noted by Hay (1927) and McCornack (1914) could be relocated in the course of this thesis. In some instances it appeared that Hay (1927) and McCornack (1914) were referencing the same specimen. The minimal information provided made this evaluation difficult. In these cases, I assumed that they were referencing different specimens and included each as a separate entry. This has possibly led to double counting. 


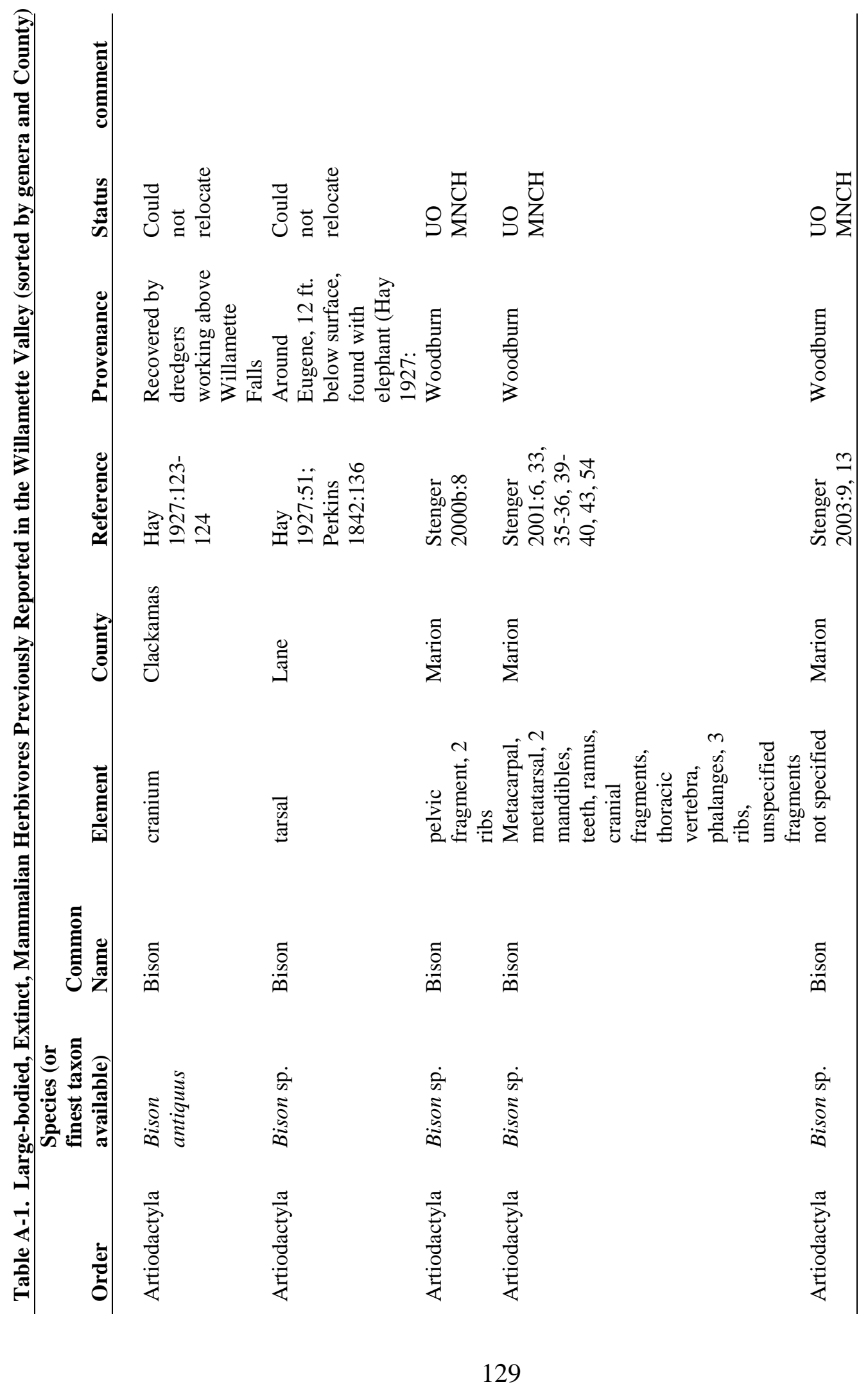




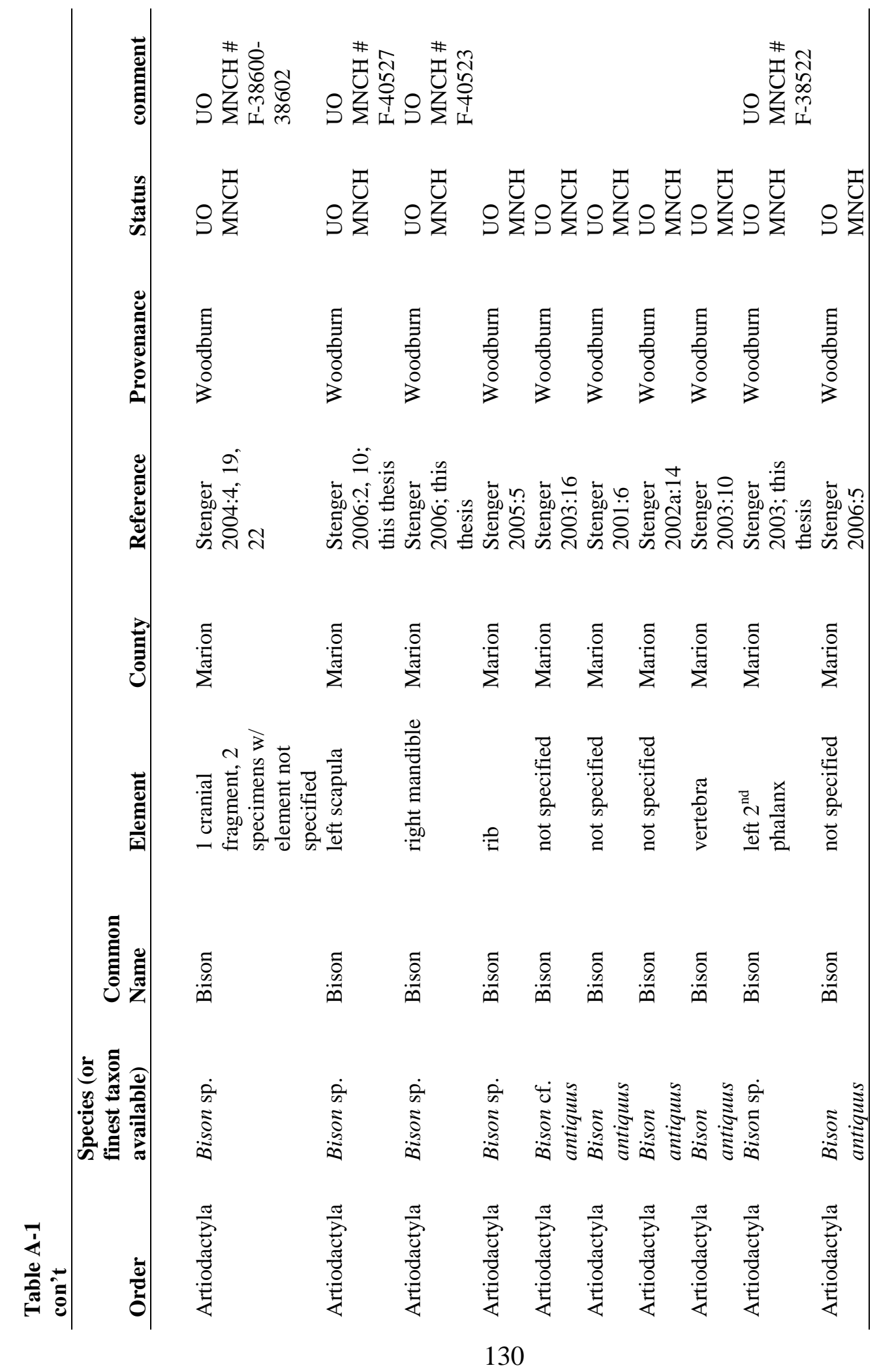




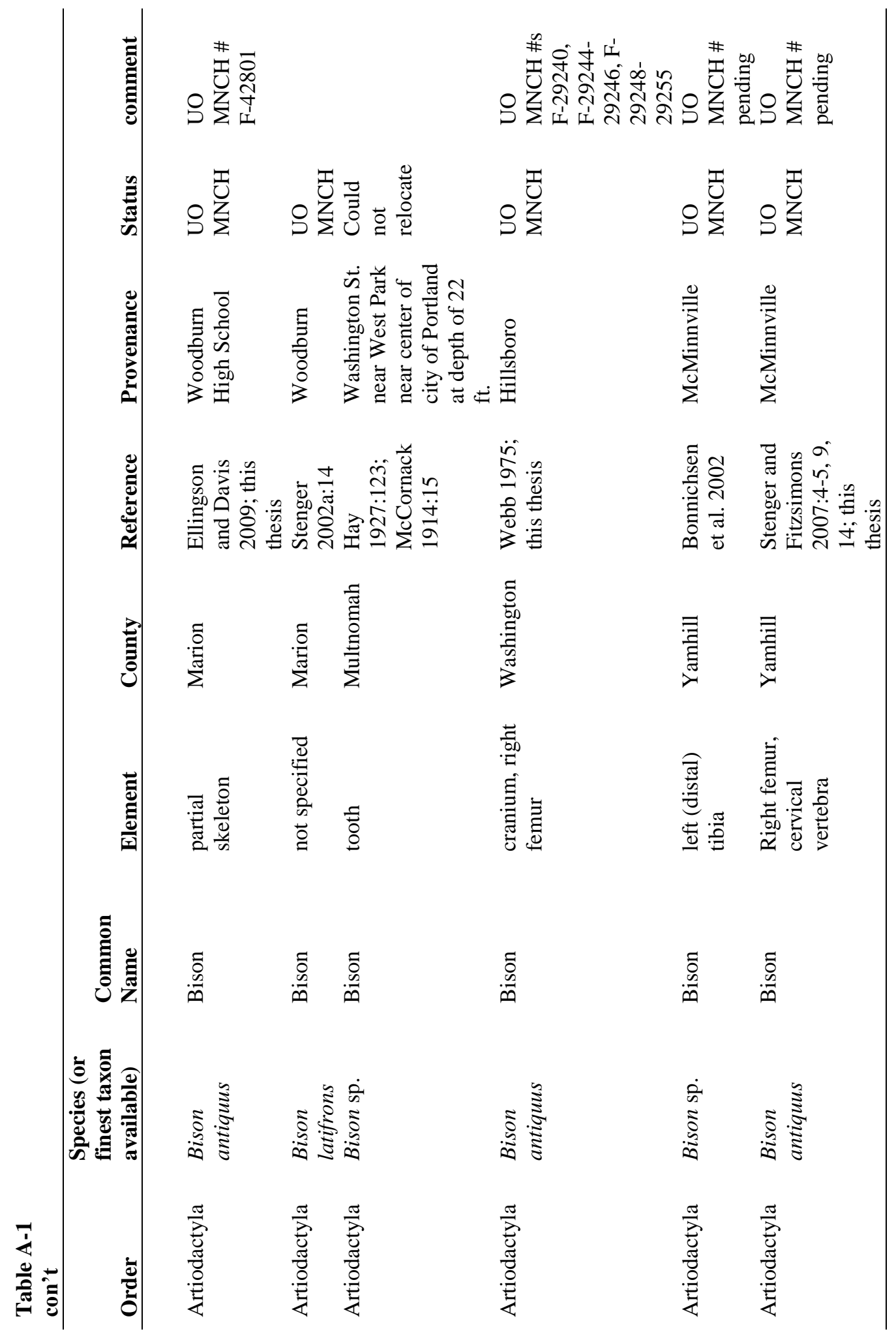




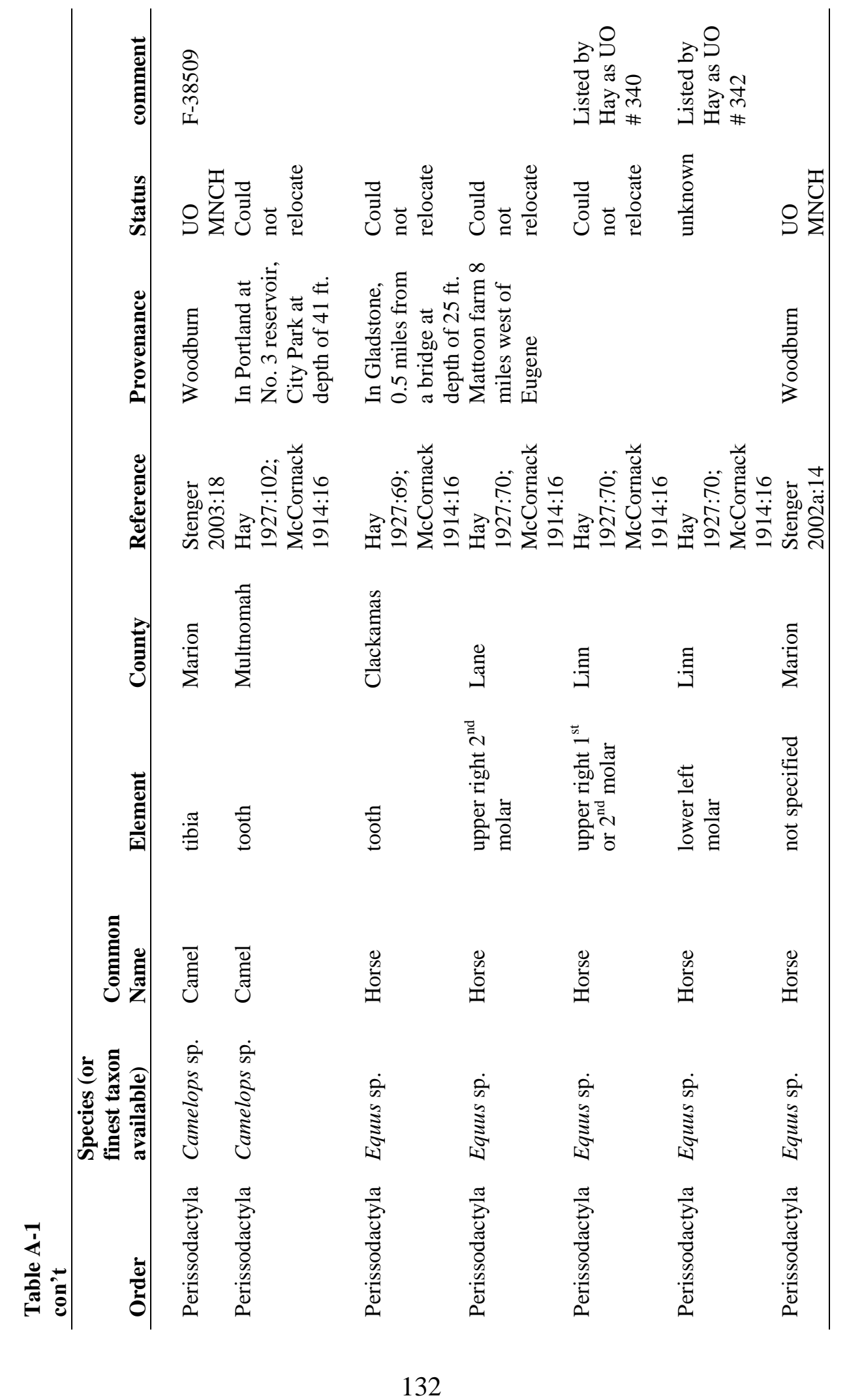




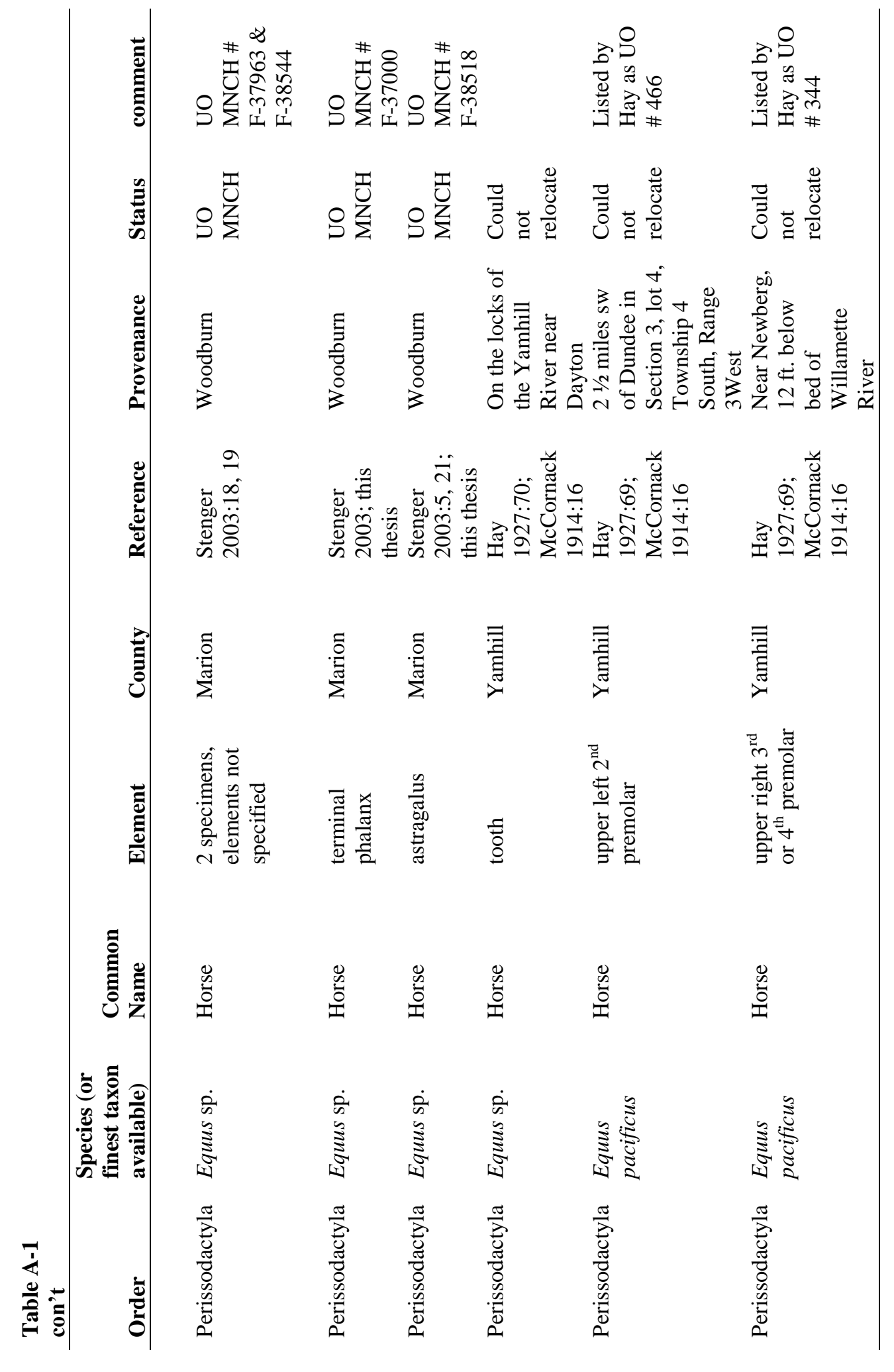




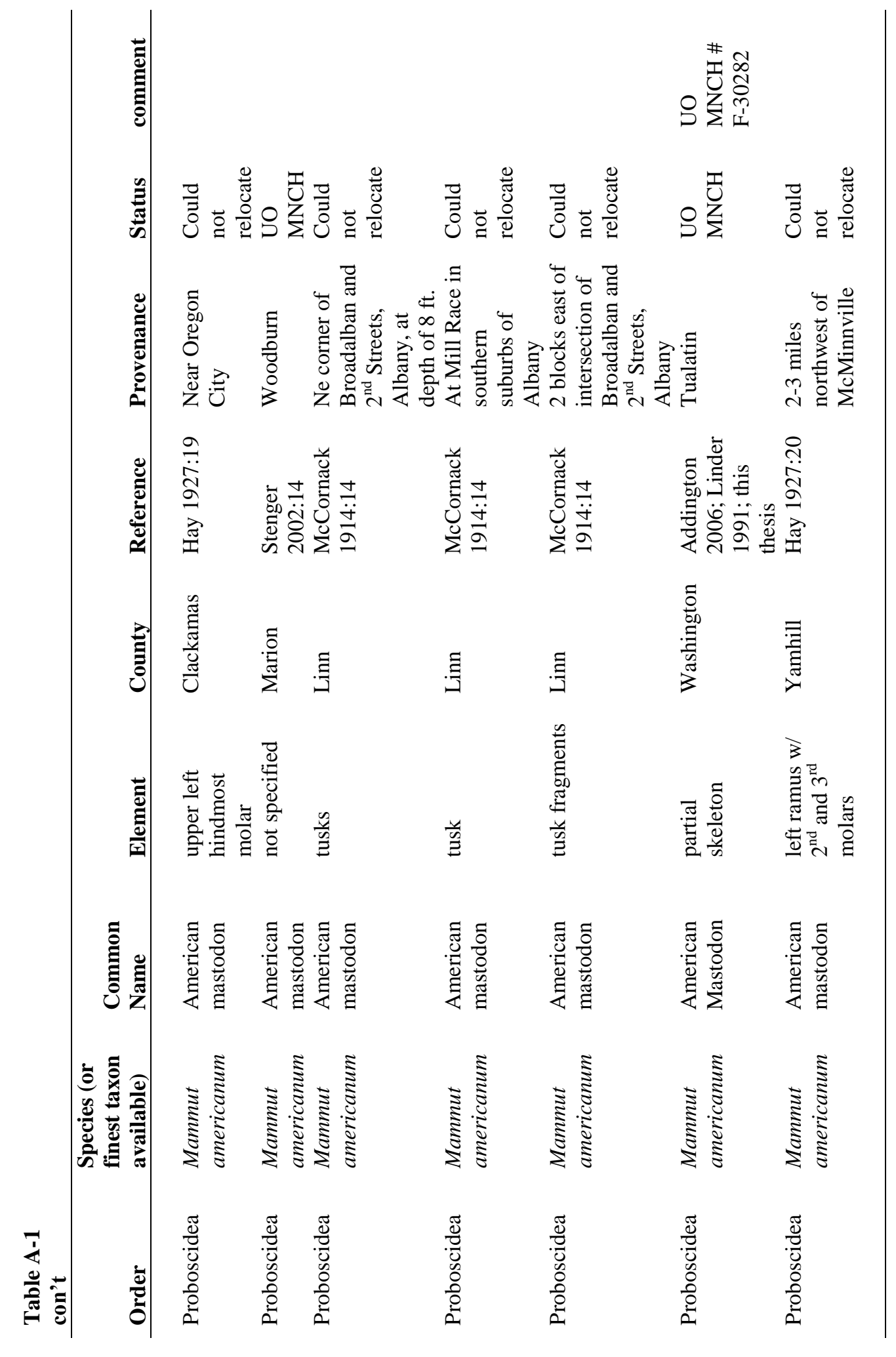




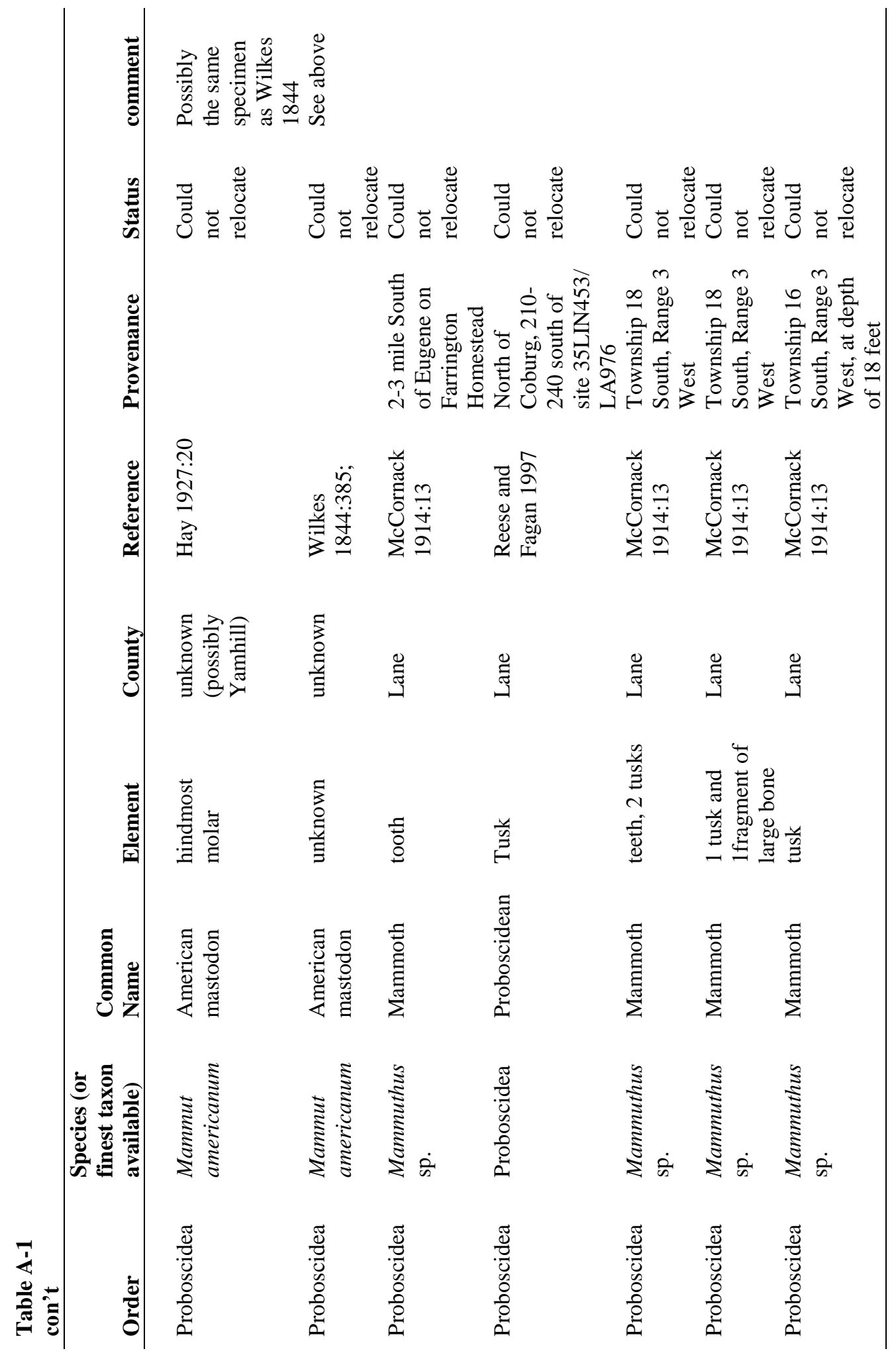




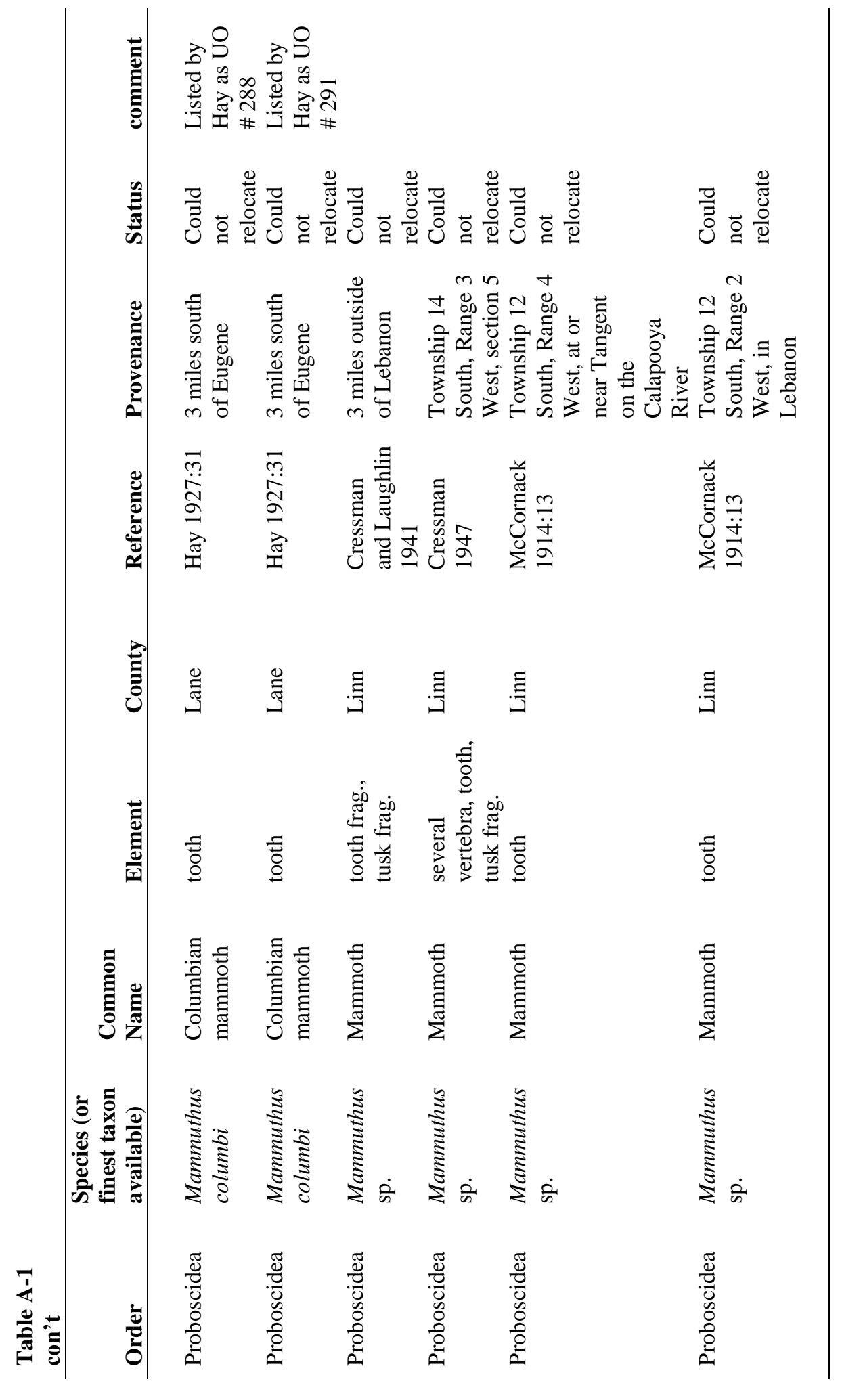




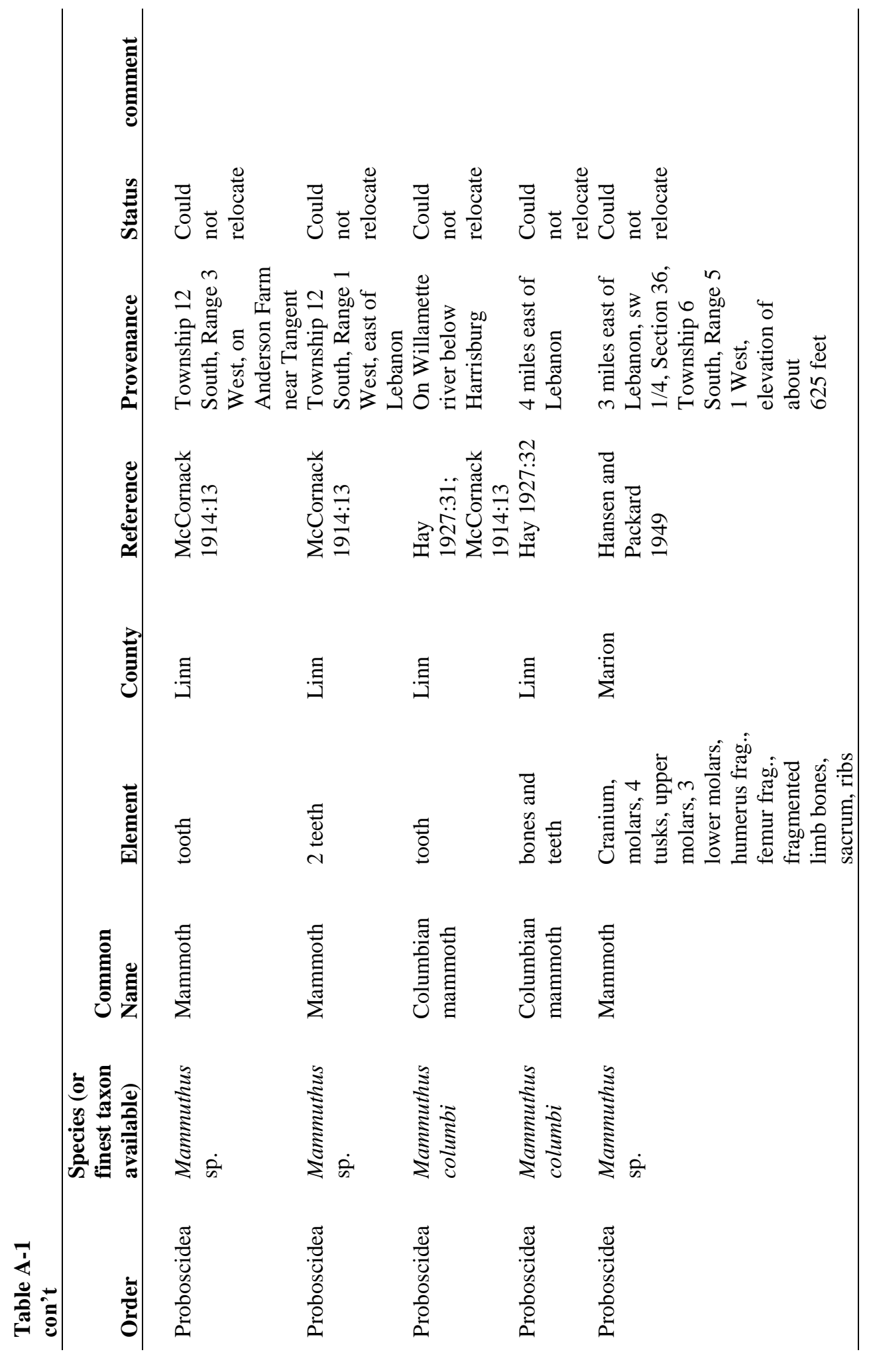




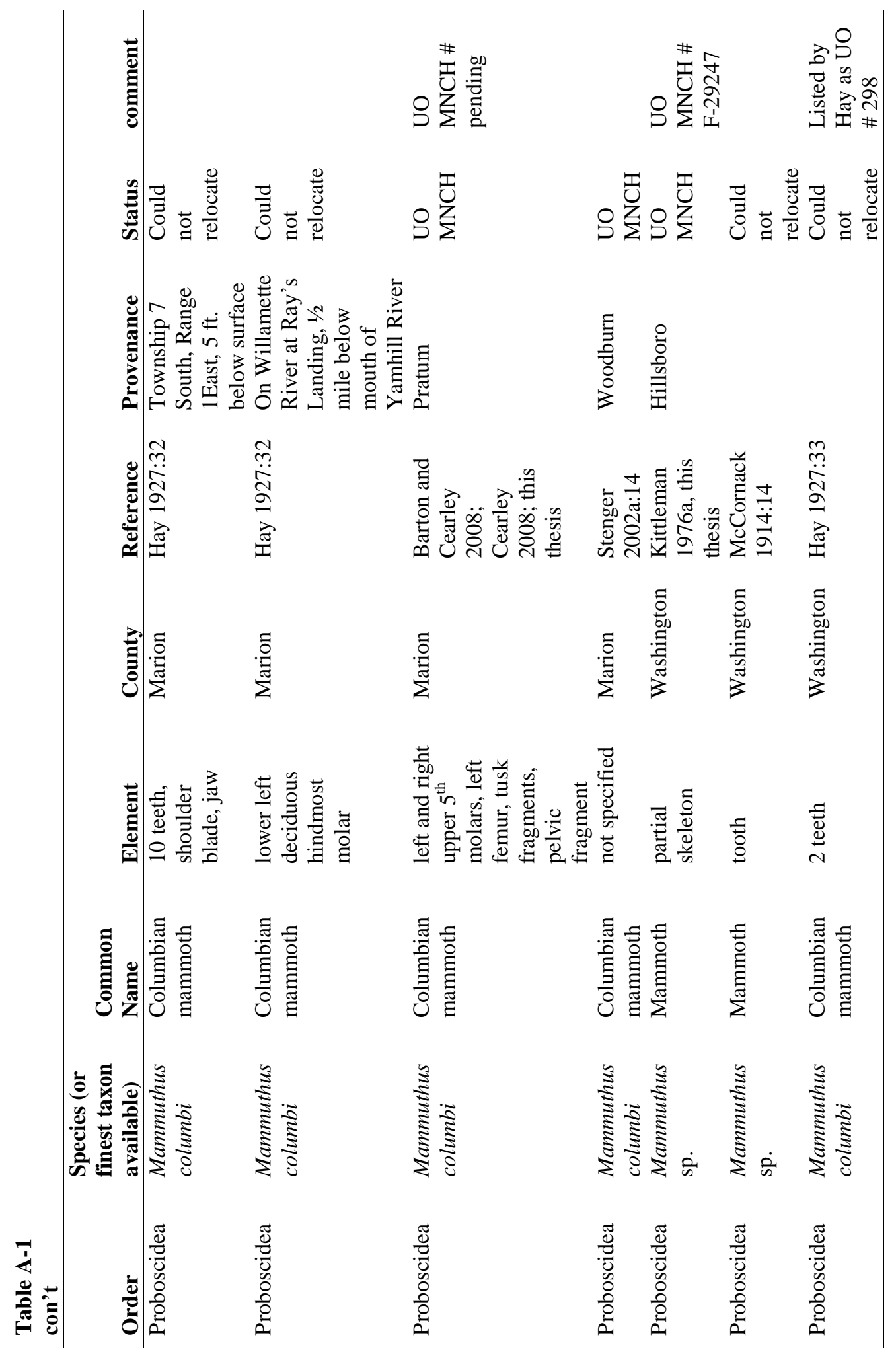




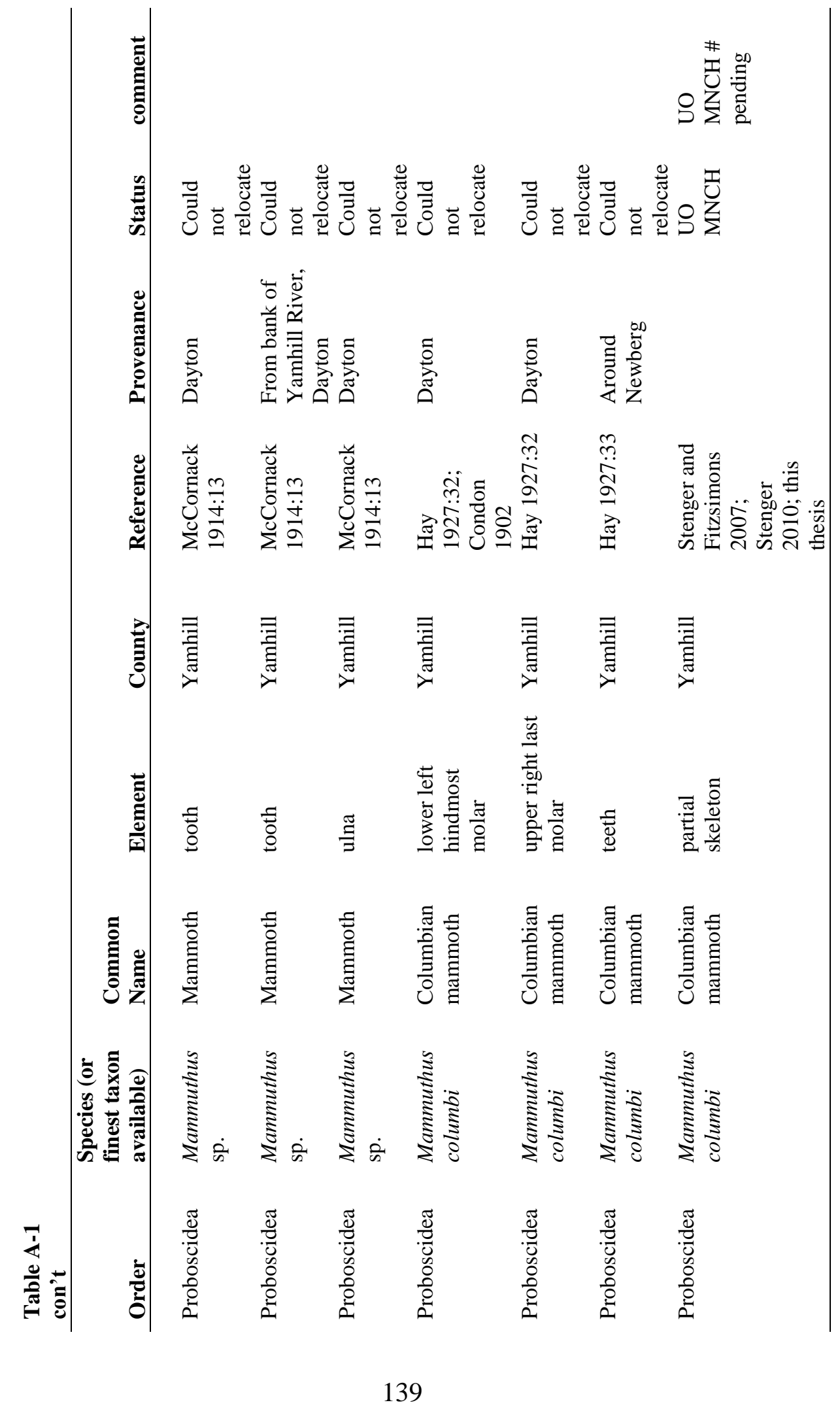




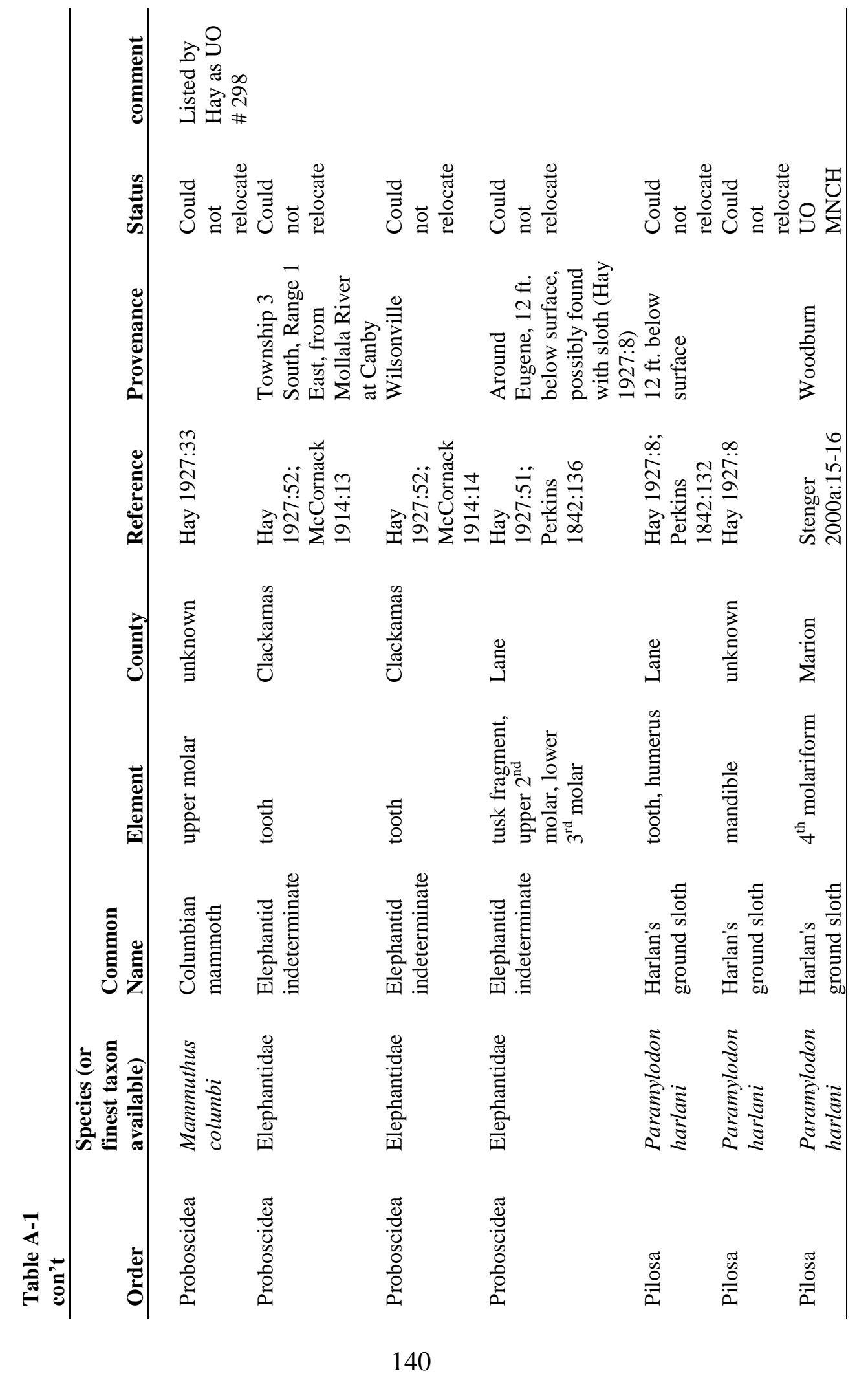




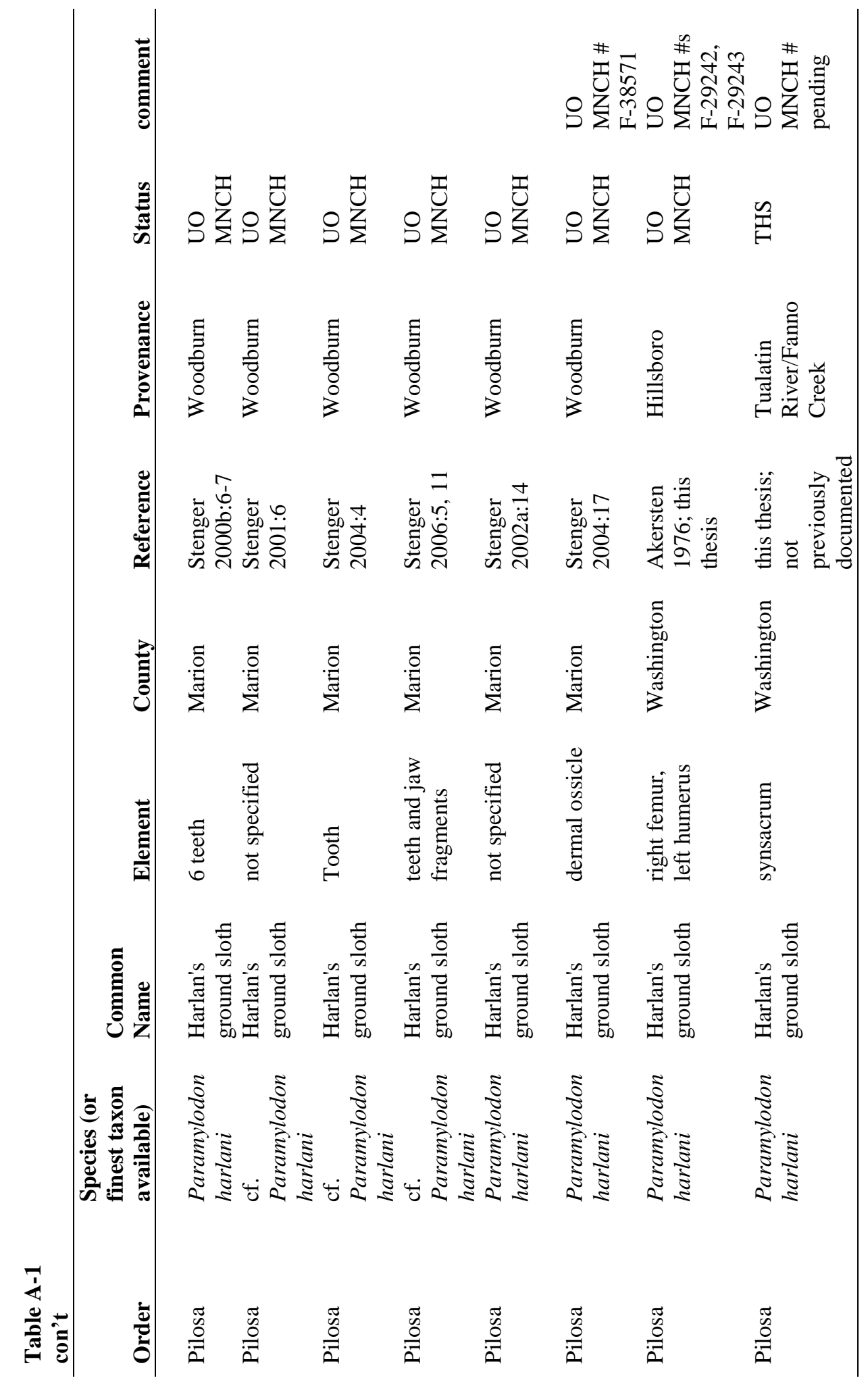




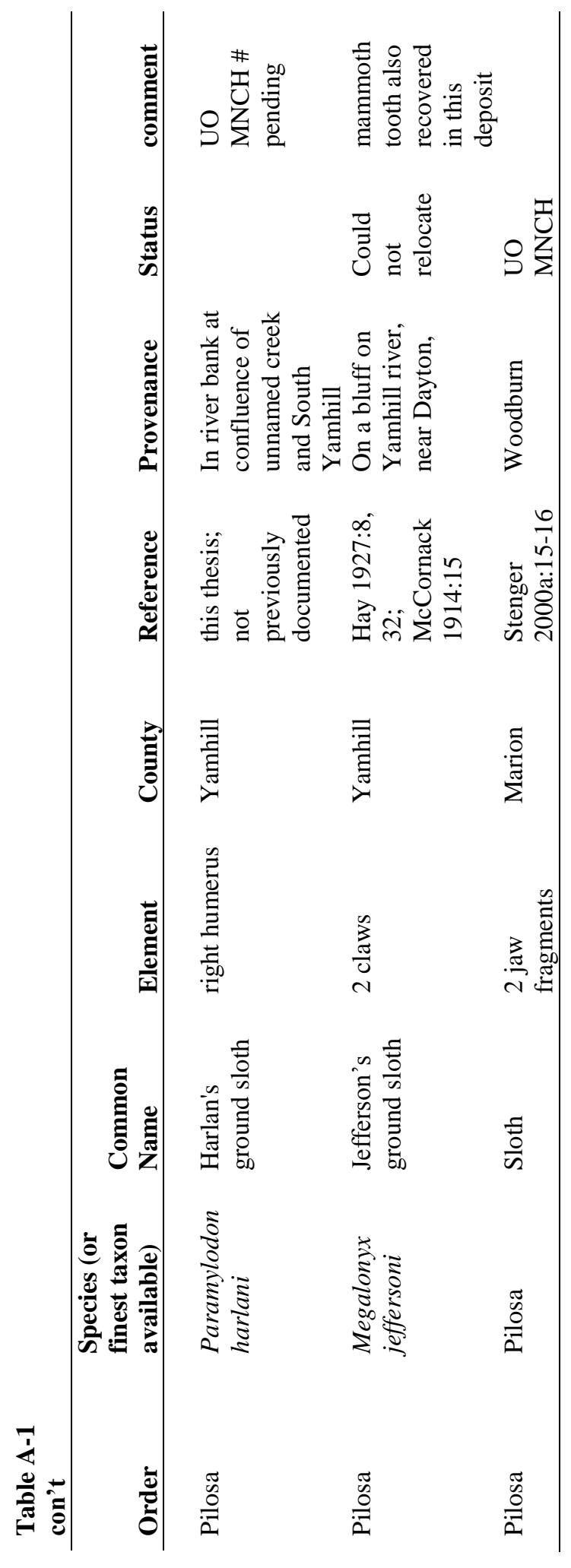


APPENDIX B: Descriptions of Paleontological Localities

The purpose of Appendix B is to describe and record the setting and history of investigation at each of the paleontological localities included in this thesis, as formal site reports or publications do not exist for some of the fossil material. Information for each paleontological locality includes: location, geomorphologic context, and history of research. Descriptions of the fossil material are provided appendices C-E.

\section{Hillsboro Locality (UO Locality 2666/ UWBM Locality C0139)}

The Hillsboro Locality is located in Washington County (Figure 5.2), two miles west of Hillsboro, Oregon. The Locality is situated in Section 50, of Township 1 South, Range 3 West, of the Forest Grove Quadrangle, in the Tualatin Valley, a sub-basin in the northwest portion of the Willamette Valley. It is located an elevation of $\sim 59 \mathrm{~m}(180 \mathrm{ft})$ on a floodplain between Dairy Creek and Council Creek, 11/2 miles north of the Tualatin River.

A report on the recovery of the fossil material was prepared in the late 1970s by Dr. Laurence R. Kittleman of the UO MNCH. This report was submitted to the UO MNCH under accession Numbers 315 and 324. Unfortunately, this report is missing from the Museum's archives and no copy is known to exist. The following information is gleaned from copies of Kittleman's personal records (correspondence with collaborators, radiocarbon report sheets, and miscellaneous documents) that he provided during a personal interview in October of 2009.

The Hillsboro Locality faunal remains were discovered in the mid-1970s when farmhands were constructing an agricultural drainage system. The landowner notified the University of Oregon of the discoveries and he eventually donated his collection of 
faunal materials to the UO MNCH. On different occasions, researchers from both the University of Oregon and the University of Washington visited the Hillsboro Locality. They collected osteological specimens from spoils spread beside the discovery site and recorded the stratigraphy of the drainage ditch (Kittleman 1976a, 1976b; Barnosky 1978). Fossil materials are currently curated at both the UO MNCH and the UWBM.

The faunal materials were recovered from the bottom of a peat bog deposit. Kittleman alternately reported this bog deposit to have been situated approximately $10 \mathrm{ft}$ or $4 \mathrm{~m}$ beneath the surface (Kittleman 1975, 1976b, 1976c) and spread over a linear distance of at least $150 \mathrm{~m}$. Researchers from the University of Washington's Quaternary Research Center (QRC) also visited the Hillsboro Locality and described the stratigraphy of the Hillsboro Locality (Barnosky 1978). Their stratigraphic sequence is presented in Table B-1. They placed the fossil material at depths between 1.8-3.7 m (6-12 ft), in Stratum 2, which corresponds with Kittleman's documents.

Kittleman's limited records suggest the peat bog contacts the Winkle Surface; but unfortunately, separate documents cite the peat bog as either overlaying or underlying the Winkle Surface (Kittleman 1976c, 1976d). Balster and Parsons (1968) described the Winkle Surface as exhibiting the morphology of abandoned flood plains of aggrading streams. In some areas of the Willamette Valley, Balster and Parsons indicated that the final stage of the formative process of the Winkle Surface is represented as former lakebeds that became inundated with peat or muck deposits. While O'Connor et al.'s (2001) study did not extend into the Tualatin Basin where the Hillsboro Locality is located, they suggest the Winkle Surface in other parts of the Willamette Valley postdates the Missoula Floods. The Winkle surface is latest Pleistocene (post-Missoula 
Flood) in origin. The age of the fossil material recovered from the Hillsboro Locality relative to O'Connor et al.'s estimated age of the Winkle Surface indicates that the peat deposits were formed over the Winkle Surface, not below it.

Table B-1. Stratigraphic Description of Hillsboro Locality (adapted from Barnosky 1978)

\begin{tabular}{llll}
\hline Stratum & $\begin{array}{l}\text { Approximate } \\
\text { Depths (in feet) }\end{array}$ & Description & Comments \\
\hline 1 & $0.0-1.5$ & soil or colluvium with organic base & \\
2 & $1.5-11$ & $\begin{array}{l}\text { organic silt w/fine detritus peat, dark } \\
\text { organic clays, and silts, fossil beetle } \\
\text { elytra }\end{array}$ & $\begin{array}{l}\text { Fossil material recovered } \\
\text { from this stratum }\end{array}$ \\
3 & $11-$ unknown & gray clayey silt & \\
\hline
\end{tabular}

Skeletal elements of a mammoth (Mammuthus sp.), a Harlan's ground sloth ( $P$. harlani), and the extinct bison, B. antiquus, were recovered from this location. Kittleman submitted two conventional radiocarbon samples to the radiocarbon laboratory at Washington State University, the first radiocarbon estimate was rendered from collagen extracted from 3 cervical vertebra of the mammoth and second from peat recovered from within the cranium of the bison (Table B-2). This study procured an additional three AMS measurements on bone collagen from each of the three individual animals (Table B-2). Associated bone chemistry and stable isotopic values of each sample were included in Table 5.4. 


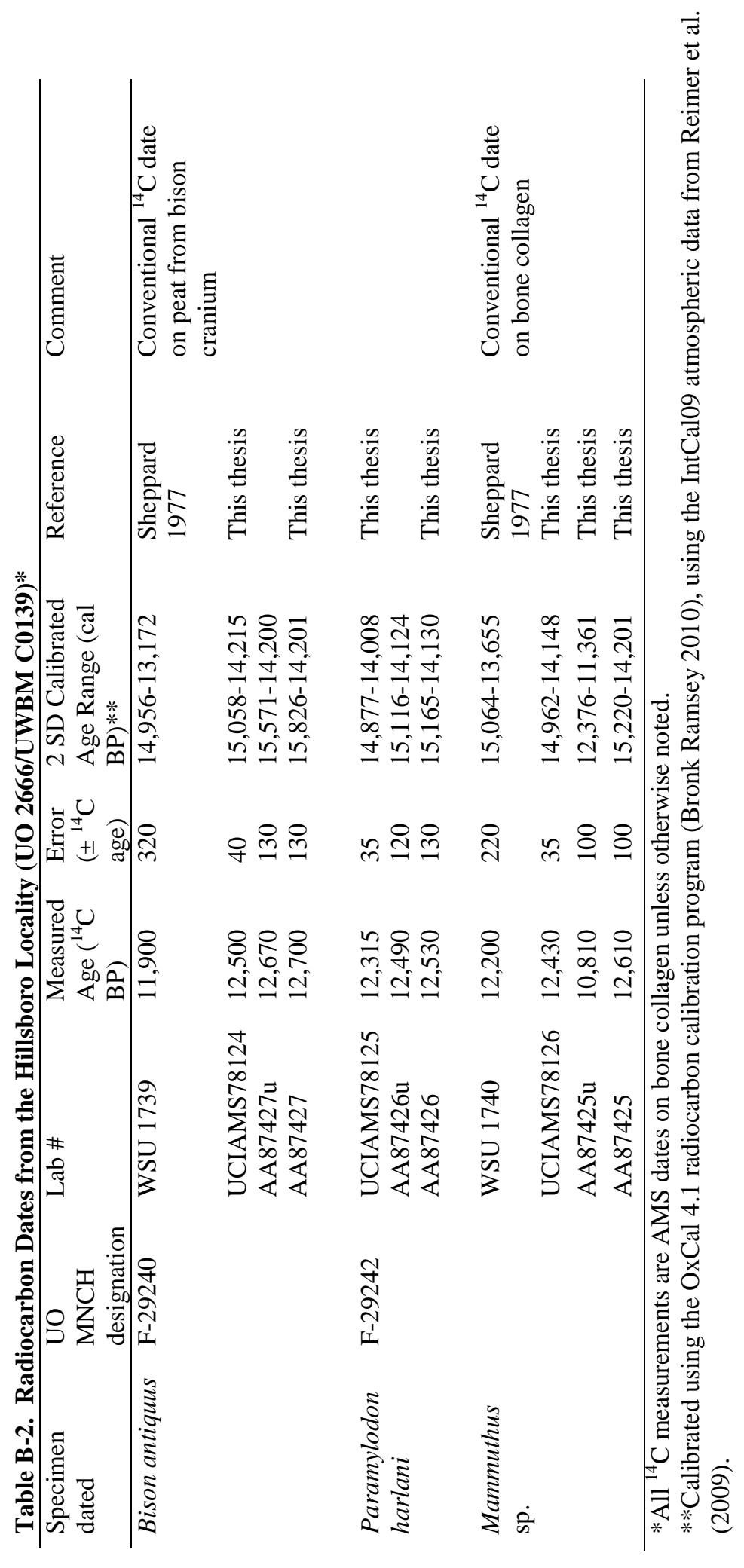




\section{McMinnville Mammoth Locality (UO 3067)}

The McMinnville Mammoth Site is located in the city of McMinnville, Yamhill County, Oregon (Figure 5.2). The Locality is located on city land adjacent to the South Yamhill River, in Section 81 of Township 4 South, Range 4 West, of the McMinnville Quadrangle, at an elevation of approximately $12 \mathrm{~m}(40 \mathrm{ft})$.

Over the last 20 years, a local avocational group has worked to identify, recover, preserve, and document the late Pleistocene paleontology in the vicinity of the city of McMinnville. The group periodically consults with professional scientists. Known as the "Yamhill River Pleistocene Project," it is directed by a retired police officer, Mr. Mike Full. Full serves as the custodian of the paleontological materials and representative of the city of McMinnville in this matter. He has lived in the McMinnville area his entire life and has worked to document its history since his first discovery of a fossil as a small boy. Information documenting the history of the study of the mammoth and other fossil localities in the McMinnville area is available on Full's website at www.yamhillriverpleistocene.com.

In 1991, Full discovered the bones of a large animal protruding from the bank of the South Yamhill River (Lysek 1999). He alerted Dr. William Orr, then a professor in the Department of Geological Sciences at the University of Oregon. Dr. Orr and Full subsequently brought the find to the attention of Dr. Robson Bonnichsen, then the director of the Center for the Study of the First Americans at Oregon State University.

Since 1991, a series of excavations has been carried out at the McMinnville Locality. Excavations were conducted every summer from 1991-1998, and continued in 2007 and 2009. The report from the 2007 field season (Stenger and Fitzsimons 2007) 
indicates that eleven $1 \mathrm{~m} \times 1 \mathrm{~m}$ units were employed. Some combination of $1 \mathrm{~m} \times 1 \mathrm{~m}$ and $1 \mathrm{~m} \times 2 \mathrm{~m}$ were employed for a total of 11 units in the 2009 field season (Stenger 2010a). Volumes excavated and maximum depths of units are not offered. A partial skeleton of a Columbian mammoth (M. columbi) and a distal fragment of a left tibia of bison were recovered from this site.

Three documents recount aspects of the paleontological investigations over the past 19 years. Bonnichsen et al. (2002) presented a conference paper that outlined the taphonomy, stratigraphy, and radiocarbon dating of the McMinnville Mammoth. Stenger and Fitzsimons (2007) and Stenger (2010a) prepared brief preliminary summaries of subsequent field investigations.

The McMinnville Mammoth was discovered in an eroding vertical wall in the right (eastern) bank of the South Yamhill River. Bonnichsen et al.'s (2002) stratigraphic description and interpretation are presented in Table B-3. According to this report, the fossil materials were recovered from a late Pleistocene terrace deposit in the upper portion of Stratum IV. Stratum IV is remarked to have been a stratigraphic layer approximately $6 \mathrm{~m}$ in depth that contained a high organic content that included woody debris, bark, and limb and tree trunks (Bonnichsen et al. 2002:7). They interpreted Stratum IV to represent a flood plain deposit. According to Bonnichsen et al. (2002), this stratum is situated beneath Missoula Flood deposits, which in turn would show an origin prior to $\sim 20,000$ cal BP. 
Table B-3. McMinnville Mammoth Site Stratigraphy (adapted from Bonnichsen et al. 2002)

\begin{tabular}{|c|c|c|c|}
\hline Stratum & Description & Interpretation & Comment \\
\hline I & $\begin{array}{l}\text { Approximately } 2 \mathrm{~m} \text { thick, composed } \\
\text { of overbank deposits and top soil. }\end{array}$ & $\begin{array}{l}\text { Seasonal overbank flooding, Holocene } \\
\text { in age. }\end{array}$ & \\
\hline II & $\begin{array}{l}\text { Complex of } 30 \text { alternating strata of } \\
\text { three laminated soil types: (1) light } \\
\text { gray silty loam, (2) red to dark red } \\
\text { loam, and (3) yellow brown loam. }\end{array}$ & $\begin{array}{l}\text { Rhythmic, banded alluvial deposits, } \\
\text { possibly associated with the last } \\
\text { Missoula Flood event. }\end{array}$ & \\
\hline III & $\begin{array}{l}\text { Variably stratified, massive, weakly } \\
\text { cemented sand and gravel unit. }\end{array}$ & $\begin{array}{l}\text { Sands and gravels indicating a period } \\
\text { of greater moisture and higher stream } \\
\text { flow than present, age unknown. }\end{array}$ & \\
\hline ------ & Unconformity. & (no details provided) & \\
\hline IV & $\begin{array}{l}\text { Blue black sandy, silty loam, with } \\
\text { some clay present. }\end{array}$ & $\begin{array}{l}\text { Anaerobic blue to black sandy loam } \\
\text { indicating a low energy depositional } \\
\text { environment. }\end{array}$ & $\begin{array}{l}\text { Fossil } \\
\text { materials } \\
\text { recovered } \\
\text { from this } \\
\text { stratum }\end{array}$ \\
\hline
\end{tabular}

Bonnichsen et al. (2002) analyzed of the fossil material, determined species, and recorded the condition of the mammoth bones. Bonnichsen and colleagues obtained an AMS radiocarbon assay that returned an infinity date of >46,400 BP (CAMS-77878) (Table B-4). Subsequent excavations (Stenger and Fitzsimons 2007; Stenger 2010a) over the last decade have resulted in the recovery of additional mammoth remains. This study acquired an additional AMS measurement on bone collagen (UCIAMS80993) that returned an infinity date of $>51,700 \mathrm{BP}$ (Table B-4). Bone chemistry and stable isotopic values were presented in Table 5.4.

Table B-4. Radiocarbon Dates for the McMinnville Mammoth (UO MNCH \# pending)

\begin{tabular}{lllll}
\hline Lab \# & $\begin{array}{l}\text { Measured } \\
\text { Age }\left({ }^{14} \mathrm{C}\right.\end{array}$ & $\begin{array}{l}\text { Error } \\
\left( \pm{ }^{14} \mathrm{C}\right. \\
\text { age })\end{array}$ & $\begin{array}{l}\text { 2 SD Calibrated } \\
\text { Age Range }(\mathrm{cal}\end{array}$ & Reference \\
& $\mathrm{BP})$ & $\mathrm{BP})$ & \\
\hline CAMS-77878 & $>46,400$ & $\mathrm{n} / \mathrm{a}$ & $\mathrm{n} / \mathrm{a}$ & Bonnichsen et al. 2002 \\
UCIAMS80993 & $>51,700$ & $\mathrm{n} / \mathrm{a}$ & $\mathrm{n} / \mathrm{a}$ & This thesis \\
\hline
\end{tabular}




\section{McMinnville Bison Locality (UO \# pending)}

The McMinnville Bison Site is located in the city of McMinnville, Yamhill County, Oregon (Figure 5.2). The Locality is located on city land adjacent to the South Yamhill River, in Section 81 of Township 4 South, Range 4 West, of the McMinnville Quadrangle. This paleontological locality is located $33 \mathrm{~m}$ upstream (south) of the previously discussed McMinnville Mammoth Locality (UO 3067) at an elevation of approximately $12 \mathrm{~m}(40 \mathrm{ft})$.

The history of research at the McMinnville Bison Locality is linked to the recovery of the McMinnville Mammoth. During an iteration of excavation at the McMinnville Mammoth in 2007, the bones of another animal were discovered protruding out of the bank of the South Yamhill. Stenger and Fitzsimons (2007:4-5) excavated six 1 $\mathrm{m} \times 1 \mathrm{~m}$ excavation units in vicinity of the original fossil remains seen obtruding from the river bank and succeeded in recovering several elements of a bison. Excavations at this locality yielded four osteological specimens, two of which were preliminarily identified as $B$. antiquus (a right femur and a cervical vertebra) and two that were only minimally identifiable as a possible vertebra and a possible rib (Yamhill River Pleistocene Project 2010). As with the aforementioned McMinnville Mammoth, additional information documenting the history of the recovery of this bison and other fossil localities in the McMinnville area are available on Full's website at www.yamhillriverpleistocene.com.

The McMinnville Bison was found in an eroding vertical wall in the right (eastern) bank of the South Yamhill River. This is the same stretch of riverbank that Bonnichsen et al. (2002) described as a late Pleistocene terrace deposit. Stenger and Fitzsimons (2007) presented a brief description of the strata they recognized (Table B-3). 
The fossil materials were recovered from Stratum 6B, described as a fine grained siltysand with light clay. This stratum is situated beneath Missoula Flood deposits, indicating an origin in excess of $\sim 20,000$ cal BP. In this study, a single AMS measurement was assayed on bone collagen (UCIAMS80992). It returned an infinity date of $>51,700 \mathrm{BP}$. Bone chemistry and stable isotopic values were presented in Table 5.4.

Table B-3. Stratigraphy of the McMinnville Bison Locality (adapted from Stenger and Fitzsimons 2007:14)

\begin{tabular}{lll}
\hline Stratum & Description & Comments \\
\hline 1 & Topsoil - silty clayey loam to silty loam & \\
$2 \mathrm{a}$ & Silty clay - FeO \& fine grained; unsorted gravel & \\
$2 \mathrm{~b}$ & Very fine grained, high Fe content & \\
3 & Clayey loam - med. brown to gray with thin mica & \\
$4 \mathrm{a}$ & Silty sand- med. brown, partly sorted $0.5-2.5 \mathrm{~cm}$ & \\
$4 \mathrm{~b}$ & Gravel - very dense FeO, 0.5 $-3.0 \mathrm{~cm}$ \\
$5 \mathrm{a}$ & Silty Sand - very fine grained, $<0.3-2.0 \mathrm{~cm}$ & \\
$5 \mathrm{~b}$ & Gravel - FeO rich, <0.3 - 2.0cm & \\
$5 \mathrm{c}$ & Silty sand- med. brown w/clay pockets, $<0.5-3 \mathrm{~cm}$ & \\
$6 \mathrm{a}$ & Silty clayey sand - within cobble layer & Bison recovered from this stratum \\
$6 \mathrm{~b}$ & Silty sand - very fine grained w/ light clay & \\
$6 \mathrm{c}$ & Sand - dark gray, with mica \& quartz grains & \\
\hline
\end{tabular}

\section{McMinnville Sloth Locality (UO Locality \# pending)}

The McMinnville Sloth Locality is located in the city of McMinnville, Yamhill County, Oregon (Figure 5.2). The paleontological locality is situated on city land in the bank of the South Yamhill River, in Section 68 of Township 4 South, Range 4 West, of the McMinnville Quadrangle at an elevation of approximately $18 \mathrm{~m}(60 \mathrm{ft})$.

Two boys discovered a fossil while they were playing in the South Yamhill River several years ago. The boys' brought the find to the attention of their father. Their father in turn notified the previously discussed Mr. Mike Full, director of the Yamhill River Pleistocene Project.

Only minimal information regarding the geologic context of this specimen is known. The fossil was found $>15 \mathrm{~m}$ below the modern surface protruding out of the left 
(western) bank of the South Yamhill River. The site was revisited by myself in September of 2010 in an attempt to learn more about the stratigraphic context and to ascertain if additional elements were present in the eroding bank of the river. Unfortunately, there were unusually high levels of rainfall in the Willamette Valley during the summer of 2010, and the locality was not accessible. Given the minimal geologic information currently available for this specimen, it was possibly not an ideal specimen to include in this study. However, the age range of this specimen encompasses the date for the first Missoula Flood ( 20,000 cal BP). The age of the Missoula Floods are not well constrained as it is rare to find radiometrically dateable material in association with Flood deposits. As such, if additional material can be recovered from the McMinnville Sloth Locality, this paleontological locality has the potential to make a significant contribution to the natural history of the Willamette Valley.

The right humerus of a Harlan's ground sloth ( $P$. harlani) was recovered from this locality. In this study, a single AMS measurement on bone collagen was procured for this specimen (UCIAMS80994). It returned a radiocarbon age of $16,620 \pm 60$, with a calibrated range of 20,064-19,479 cal BP (Table 5.5). Bone chemistry and stable isotopic values were presented in Table 5.4.

\section{Pratum-Rutschman/Qualey Locality (UO locality \# pending)}

The PRQ Locality is located in the community of Pratum, Marion County, Oregon (Figure 5.2), near Howell Prairie between the towns of Salem and Silverton, in Section 6 of Township 7 South, Range 1 West, in the Stayton NE Quadrangle. It is located an elevation of $\sim 64 \pm 3 \mathrm{~m}$ ( $209 \mathrm{ft}$ ) in the Pudding River watershed (Barton and Cearley 2008). 
The PRQ Mammoth was discovered in 1967 by Roy Rutschman and Norm Qualey during a backhoe excavation for a farm pond on Rutschman's property. The men uncovered several elements of a Columbian Mammoth (M. columbi), which have remained in the custody of the discoverers' families since that time. An article documenting this mammoth was recently published (Barton and Cearley 2008), the first article documenting Willamette Valley megafauna to appear in a peer-reviewed journal in over half a century (Hansen and Packard 1949). In conjunction with this thesis, a portion of the fossils have been donated by the Rutschman family to the UO MNCH.

The paleontological site sits on a low terrace of the Pudding River. This terrace is in turn situated at the base of a riser to another terrace. Geologically, the area is primarily identified as the main body of fine-grained Missoula Flood deposits (O’Connor et al. 2001). In addition, along the banks of streams, O'Connor et al. cite the presence of Holocene and upper Pleistocene deposited alluvium consisting of unconsolidated clay, silt, and minor gravel. The paleontological materials were contained within a bog that developed on a depression in Missoula Flood deposits (Cearley 2008).

Cearley (2008) reconstructed the stratigraphic context of the fossil find. An original account of the discovery of the megafauna remains stated that the fossils were unearthed at a depth of between 1.8-2.4 m (6-8 ft) below the surface from a peat bog deposit (The Silverton Appeal 1967). Based on field visits to the locality and observations at a nearby cutbank of the Pudding River, Cearley (2008) noted two stratigraphic units: a light brown sandy loam extending from the surface to a depth of approximately $2 \mathrm{~m}$ and a dark brown silt or clay that extended below the water level. 
Cearley placed the megafauna remains at the interface of the two layers, $2 \mathrm{~m}(6.5 \mathrm{ft})$ beneath the surface.

Barton and Cearley (2008) assigned the remains to M. columbi based on morphometric analysis of the molars. Based on epiphyseal fusion, the PRQ Mammoth appears to be a mature adult. Their metric analysis of the molars indicated the animal to be $24.5 \pm 3$ African Elephant Years in age at death, placing it in the "early prime adult" social group. They submitted a sample of dentine from the last dental plate of one of the molars to the Waikato Lab for radiometric and stable isotopic analyses. This sample returned an AMS date in uncalibrated radiocarbon years of 12,023 $\pm 77 \mathrm{BP}$ (Wk-21807), with a calibrated age range of 14,081-13,706 (Table 5.5, Figure 5.4). Bone chemistry and stable isotopic values were presented in Table 5.4. An attempt to re-date the PRQ Mammoth during this study did not yield sufficient collagen.

\section{Tualatin Locality (UO 2840)}

UO Locality 2840 lies within the limits of the City of Tualatin, Washington County, Oregon (Figure 5.2). This paleontological locality is situated in Section 24 of Township 2 South, Range 1 West, in the Beaverton Quadrangle. The paleontological locality is located approximately $450 \mathrm{~m}$ south of the Tualatin River and $100 \mathrm{~m}$ north of Nyberg Creek. Currently, the Tualatin Locality lies under the south end of a paved parking lot of a Fred Meyer shopping center. It is situated on the floodplain of the Tualatin River, a tributary to the Willamette River. The site lies at an elevation of $\sim 36 \mathrm{~m}$ (120 ft).

History of the discovery and excavation is known from records kept by Yvonne Addington, a longtime board member of the Tualatin Historical Society (THS) and 
retired Tualatin city manager. Ms. Addington has labored for many years to preserve all relevant information regarding the Tualatin Mastodon and its recovery, such as photodocumentation of its excavation, the original account of its recovery (George and Sund 1962), and interviews with original discoverers. The following is drawn from her work (Addington 2006) on file at the Tualatin Heritage Center.

In the late 1940s, Tualatin Town Constable Charlie Roberts discovered three molars of a mastodon less than 1 foot below surface while digging an irrigation ditch on a friend's property. For years thereafter, Constable Roberts displayed the molars in his home, utilized one molar as a doorstop, and often related the story of his findings to the local populace. In 1962, two undergraduates at Portland State University (PSU), John George and Ron Sund, decided to retrieve the remainder of the mastodon skeleton as part of their final project in a "Geology of Oregon" class at PSU, based on location information provided by Constable Roberts.

In April of 1962, they recovered what would become known as the "Tualatin Mastodon" and presented a report on their project as their final term paper at PSU (George and Sund 1962). George and Sund recovered the axial elements (minus cranium and mandibular elements) and the left appendicular elements of the Tualatin Mastodon. They noted the presence of cranial fragments and were not able to locate any of the right appendicular elements. George and Sund stated that the possibility existed that additional elements could be present in the area. Time and weather constraints prevented them from conducting a more extensive program of subsurface exploration in the area.

Since its recovery, the Tualatin Mastodon was displayed/stored in a variety of locations. Initially, most of the Mastodon was put on display at PSU while George 
maintained possession of a tusk and two molars as his personal property (Addington 2006). In 1973, PSU transferred possession of the skeleton to the City of Tualatin in care of Yvonne Addington who kept it in storage at the City Public Works until 1982. From 1982-1991, the Tualatin Mastodon was stored at the Washington Park Zoo in Portland. In 1991, the zoo transferred ownership to the THS.

Upon attaining ownership of the Mastodon, the THS sought to preserve, study, and display it. The THS raised money to hire a paleontologist, Robert Linder of the Department of Geological Sciences at the University of Oregon, to prepare the Mastodon for display in Tualatin City Hall. Linder preserved, articulated, and briefly described the specimen (Linder 1992).

The Tualatin Mastodon was displayed in City Hall until it was transferred to the City's newly completed library in 2009. The articulated skeleton is the centerpiece display of the recently renovated Tualatin Public Library, located at $18880 \mathrm{SW}$ Martinazzi Avenue, Tualatin, Oregon, 97062. The Tualatin Mastodon represents a tremendous source of civic pride for the local community.

Minimal documentation exists that describes the stratigraphic profile of the site. George and Sund's excavation located portions of the Mastodon at depths between $\sim 1$ $1.5 \mathrm{~m}$ (3.5-5 ft) below the surface. George and Sund (1962) did not describe stratigraphy in detail but made brief notes and photographed their progress during the course of the excavation (Addington 2006). Prior to commercial development over the past several decades, the area in which the Tualatin Mastodon was recovered was described by local residents as "mucky swamps" (Addington 2006). Linder notes that the Mastodon skeleton was "apparently mired in the muck of a swampy peat bog" (Linder 1992:1). The 
Natural Resource Conservation Service (NRCS 2010) lists the predominant soils in the area as belonging to the Wapato series (recent alluvium) with minor elements of the Labish series, alluvium and lacustrine deposits over organic material accumulated in floodplains and relict lakebeds. The NRCS descriptions indicate the presence of peat deposits at a depth of just under $1 \mathrm{~m}(3 \mathrm{ft})$ in Labish series deposits, which seems consistent with what is known of the site's stratigraphy from George and Sund's (1962) document and Linder's (1992) manuscript.

The osteological elements recovered by George and Sund are differentially represented. All elements recovered are either axial or left sided appendicular elements. When recovered by George and Sund, the animal was described as laying on its left side (Addington 2006; Linder 1992). While the Tualatin Mastodon was recovered from an area that was characterized as swamps prior to late $20^{\text {th }}$ century reclamation activities, it had been the locus of some historic agricultural activities such as draining and plowing. These potentially intrusive actions are possible explanations for the differential representation of elements. Linder (1992) also cited the possibility that the right sided elements had been removed by scavengers or erosional forces.

The partial skeleton of American mastodon (Mammut americanum) recovered from this locality has been radiometrically dated several times. Linder (Addington 2006) obtained a conventional radiocarbon measurement on bone collagen and this study added three additional bone collagen AMS measurements (Table B-4). Associated bone chemistry and stable isotopic values were presented in Table 5.4. 
Table B-4. Radiocarbon Dates for the Tualatin Mastodon (UO MNCH \# F-30282)

\begin{tabular}{lllll}
\hline Lab \# & $\begin{array}{l}\text { Measured Age } \\
\left(\begin{array}{l}\left.{ }^{14} \mathrm{C} \mathrm{BP}\right)\end{array}\right.\end{array}$ & $\begin{array}{l}\text { Error } \\
\left( \pm{ }^{14} \mathrm{C}\right. \\
\text { age })\end{array}$ & $\begin{array}{l}\text { 2 SD Calibrated Age } \\
\text { Range (cal BP)* }\end{array}$ & Reference \\
\hline Beta-52055 & 11,280 & 100 & $13,367-12,907$ & Addington 2006 \\
UCIAMS78127 & 11,480 & 35 & $13,441-13,245$ & This study \\
AA87428u & 11,570 & 120 & $13,723-13,205$ & This study \\
AA87428 & 11,490 & 110 & $13,608-13,134$ & This study
\end{tabular}

*Calibrated using the OxCal 4.1 radiocarbon calibration program (Bronk Ramsey 2010), using the IntCal09 atmospheric data from Reimer et al. (2009).

\section{Tualatin River-Fanno Creek Locality (UO Locality \# pending)}

The Fanno Creek-Tualatin River Locality is located in the City of Tigard,

Washington County, Oregon (Figure 5.2). It lies within Section 13 of Township 2 South, Range 1 West of the Beaverton Quadrangle. The Tualatin River-Fanno Creek Locality is situated west of and adjacent to Fanno Creek, approximately $1.2 \mathrm{~km}$ north of Fanno Creek's confluence with the Tualatin River. This paleontological locality is situated in the approximate vicinity of the current property line of the Durham School and the Durham Waste Water Treatment Facility. It lies at an elevation of approximately $\sim 45 \mathrm{~m}$ (148 ft). The area from which the fossils were recovered is composed of floodplains and gently inclined terraces.

Knowledge of the history of the discovery of this specimen comes from Yvonne Addington of the THS (Yvonne Addington, personal communications 2008, 2009). The specimen was donated to the THS by Dr. Robert MacDonald, by way of Mr. Ernest Rowland. The specimens were discovered by Rowland while excavating with a backhoe for emplacement of a sewage line in a swampy field, sometime in the late 1960s or early 1970s. The fossil material has been in the custody of the THS for several years. It is currently displayed at the Tualatin Heritage Center. In conjunction with this thesis, the 
THS and the UO MNCH have entered into a relationship and are in discussions on how jointly work to preserve the fossil in the UO MNCH while the THS maintains possession.

Given the passage of time since the fossil was discovered, data on the geologic context of the find is imprecise. The location in the field at which the megafaunal remains were encountered is also inexact. The fossil material was recovered from depths of between $2-4.5 \mathrm{~m}(7-15 \mathrm{ft})$ below the surface. While the contextual information is poor, the specimens likely post-date or are contemporary with Missoula Flood deposits, as the Willamette Valley lowlands were blanketed by deposits of gravel and sediments that are in some areas over $30 \mathrm{~m}$ thick (O'Connor et al. 2001). The radiocarbon dates secured in this thesis corroborate a post-Flood genesis for this specimen of $P$. harlani. This locality yielded a synsacrum (sacrum with attached last/third lumbar vertebra) of $P$. harlani, Harlan's ground sloth. Three bone collagen AMS dates on bone collagen were acquired for this specimen (Table B-5). Associated bone chemistry and stable isotopic values were presented in Table 5.4.

Table B-5. Radiocarbon Dates for the Tualatin River-Fanno Creek Sloth (UO MNCH \# pending)

\begin{tabular}{lllc}
\hline Lab \# & $\begin{array}{l}\text { Measured Age } \\
\left({ }^{14} \mathrm{C} \mathrm{BP}\right)\end{array}$ & $\begin{array}{l}\text { Error } \\
\left( \pm{ }^{14} \mathrm{C} \text { age }\right)\end{array}$ & $\begin{array}{c}\text { 2 SD Calibrated Age Range } \\
(\text { cal BP)** }\end{array}$ \\
\hline UCIAMS78123 & 12,340 & 35 & $14,889-14,036$ \\
AA87429u & 12,600 & 35 & $15,439-14,135$ \\
AA87429 & 12,700 & 130 & $15,826-14,201$ \\
\hline *Calibrated using the OxCal 4.1 radiocarbon calibration program (Bronk Ramsey \\
2010), using the IntCal09 atmospheric data from Reimer et al. (2009).
\end{tabular}

\section{Woodburn High School Locality (UO 2596)}

The Woodburn High School Locality is situated on the grounds of Woodburn Senior High School, in the city of Woodburn, Marion County, Oregon (Figure 5.2). This 
locality is positioned in Section 51 of Township 5 South, Range 1 West, of the Woodburn Quadrangle. The paleontological locality is situated at an elevation of $\sim 47 \mathrm{~m}(155 \mathrm{ft})$ within the Mill Creek drainage, a tributary to the Pudding River.

The Woodburn High School Locality is the site of an ongoing high school science project under the direction of an instructor in freshman biology, Mr. David Ellingson. The project aims to teach students about the paleoenvironment of the area. In this endeavor, a backhoe is used to unearth a Terminal Pleistocene $(\leq 15,000 \mathrm{cal}$ BP $)$ aged peat bog that is known to exist in and around the Mill Creek drainage. Students manually extract samples of the Pleistocene peat bog and dig through the mechanically excavated sediments in order to recover floral and faunal samples. In one such undertaking in the September of 2008, a Woodburn science class uncovered a skeletal elements of a large mammal later identified as a bison. Additional skeletal elements were recovered in later years. As part of my thesis, I introduced Ellingson to the curator of fossils of the UO MNCH, Dr. Edward Byrd Davis. Ellingson and the UO MNCH have reached some agreement to accession the bison into the $\mathrm{UO} \mathrm{MNCH}$ collection while ownership of the bison is maintained by Woodburn Senior High School. Subsequently, Ellingson and Davis (2009) presented the preliminary results of an analysis of this individual at a recent conference.

O’Connor et al. (2001) note two surficial geologic units in this area. Most of this area of the Willamette Valley is designated as the main body of fine-grained Missoula Flood deposits. Additionally, in vicinity to Mill Creek they cite the presence of alluvium of smaller streams dating to the Holocene and Upper Pleistocene. Soil types present in 
the immediate vicinity consist of alluvially deposited Bashaw clays and Labish silty clay loams that are indicative of relict lakebeds (NRCS 2010).

I documented the stratigraphy of this locality in September of 2009. An operator excavated a trench measuring $4.6 \mathrm{~m} \times 1.5 \mathrm{~m} \times 5.7 \mathrm{~m}$ adjacent to where the bison had been recovered the previous year. Sediments were excavated using a smooth-edged bucket and laid out parallel to the trench in the order in which they were excavated. Though visibility into the trench was limited, I outlined a stratigraphic profile (Table B-7). The paleontological materials were located directly at the interface of Strata 3 and 4 at a depth of $5.1 \mathrm{~m}$ below the surface.

Table B-7. Woodburn High School Locality Stratigraphy

\begin{tabular}{llll}
\hline Stratum & $\begin{array}{l}\text { Depth } \\
\text { (in meters) }\end{array}$ & Description & Comment \\
\hline 1 & $0-1.1$ & Dark brown silty clay loam & \\
2 & $1.1-1.9$ & $\begin{array}{l}\text { Gray brown/dark gray clay } \\
\text { Peat bog deposit - grades into a dark } \\
\text { organic silt with increasing depth }\end{array}$ & $\begin{array}{l}\text { Fossil materials were } \\
\text { recovered at the interface of } \\
\text { Strata 3 \& 4 }\end{array}$ \\
\hline
\end{tabular}

A partial skeleton of an extinct bison, Bison antiquus, was recovered at Woodburn High School. A series of radiometric measurements were acquired for this individual during this study (Table B-8). Bone chemistry and stable isotopic values were presented in Table 5.4.

Table B-8. Radiocarbon Dates for the Woodburn High School Bison (UO MNCH \# F-42801)

\begin{tabular}{lllc}
\hline Lab \# & $\begin{array}{l}\text { Measured Age } \\
\left({ }^{14} \mathrm{C} \mathrm{BP}\right)\end{array}$ & $\begin{array}{l}\text { Error } \\
\left( \pm{ }^{14} \mathrm{C} \text { age }\right)\end{array}$ & $\begin{array}{c}\text { 2 SD Calibrated Age Range } \\
(\text { cal BP)* }\end{array}$ \\
\hline UCIAMS78133 & 11,300 & 40 & $13,295-13,105$ \\
AA87430u & 11,320 & 120 & $13,429-12,909$ \\
AA87430 & 11,310 & 110 & $13,405-12,920$ \\
AA87431u & 11,470 & 100 & $13,567-13,127$ \\
AA87431 & 11,460 & 120 & $13,603-13,108$ \\
\hline *Calibrated using the OxCal 4.1 radiocarbon calibration program (Bronk Ramsey \\
2010), using the IntCal09 atmospheric data from Reimer et al. (2009).
\end{tabular}




\section{Woodburn-Legion Park Localities (UO 3038, UO 3064, \& UO 3867)}

The Legion Park localities are located in the city of Woodburn, Marion County, Oregon (Figure 5.2). These localities are situated in Section 50 of Township 5 South, Range 1 West, of the Woodburn Quadrangle. Legion Park is situated at an elevation of $\sim 42 \mathrm{~m}(170 \mathrm{ft})$ immediately adjacent to Mill Creek, the eastern flank of which has been the focus of the investigations.

Exploratory mechanical excavations have occurred in different locations in, or immediately adjacent to Legion Park, a public recreational area. Two such locations (UO 3038 and 3064) are situated within the city park itself. Meanwhile, a third locality (UO 3867) is situated on the immediately adjacent privately owned Van Valkenberg parcel that abuts the north end of Legion Park. While each instance of excavation has been granted its own unique locality number by the $\mathrm{UO} \mathrm{MNCH}$ for administrative purposes, they are considered here as a single unit.

Over the last decade, the Woodburn area has been investigated by Alison Stenger and described in a series of preliminary reports (Stenger 1996, 2000a, 2000b, 2001, 2002a, 2002b, 2003, 2004, 2005, 2006, 2010b). The project's goals are to recover paleontological and/or archaeological remains and artifacts from Terminal Pleistocene $(\leq 15,000$ cal BP) peat deposits that exist in the Woodburn area at depths of $\sim 1-5 \mathrm{~m}$ below the surface. In this pursuit, Stenger has executed mechanical excavation of a series of backhoe trenches. The excavated spoils were then deposited on the ground and examined by a crew of avocational volunteers.

Geologically, the area is mapped by O'Connor et al. (2001) as consisting of the main body of fine-grained Missoula flood deposits. Stenger provides a variety of 
stratigraphic descriptions for her trenches. The most thorough seems to appear in her 2002 account (Stenger 2002a:15), shown in Table B-9.

A variety of micro- and macro-fossils have been recovered over the years at Legion Park. Five different specimens (two equids and three bison) recovered during three different phases of mechanical excavation are included in this thesis. Unlike the previously discussed paleontological localities where multiple specimens were recovered from a single stratigraphic layer, the Legion Park specimens were recovered from different trenches in different areas of the park. Furthermore, the fossil material was recovered from spoils dumped by a mechanical excavator. In this process, sediments from multiple layers sometimes became mixed and the field crew was not always able to discern the stratum from which the fossil materials originated. The geologic context associated with each specimen is presented in Table B-10.

Every effort was made to sample skeletal elements from different individual animals. For each taxon (Equus sp., Bison sp.), I included bones for specialized analyses from separate trenches (Table B-10). If elements from individual animals were widely scattered, then this sampling may not have avoided the problem of "double counting." Given the similar radiometric and isotopic measurements (Tables 5.4, B-11) for Equus sp. (F-37000, F-38518) and Bison sp. (F-40523, F-40527), this appears likely. 


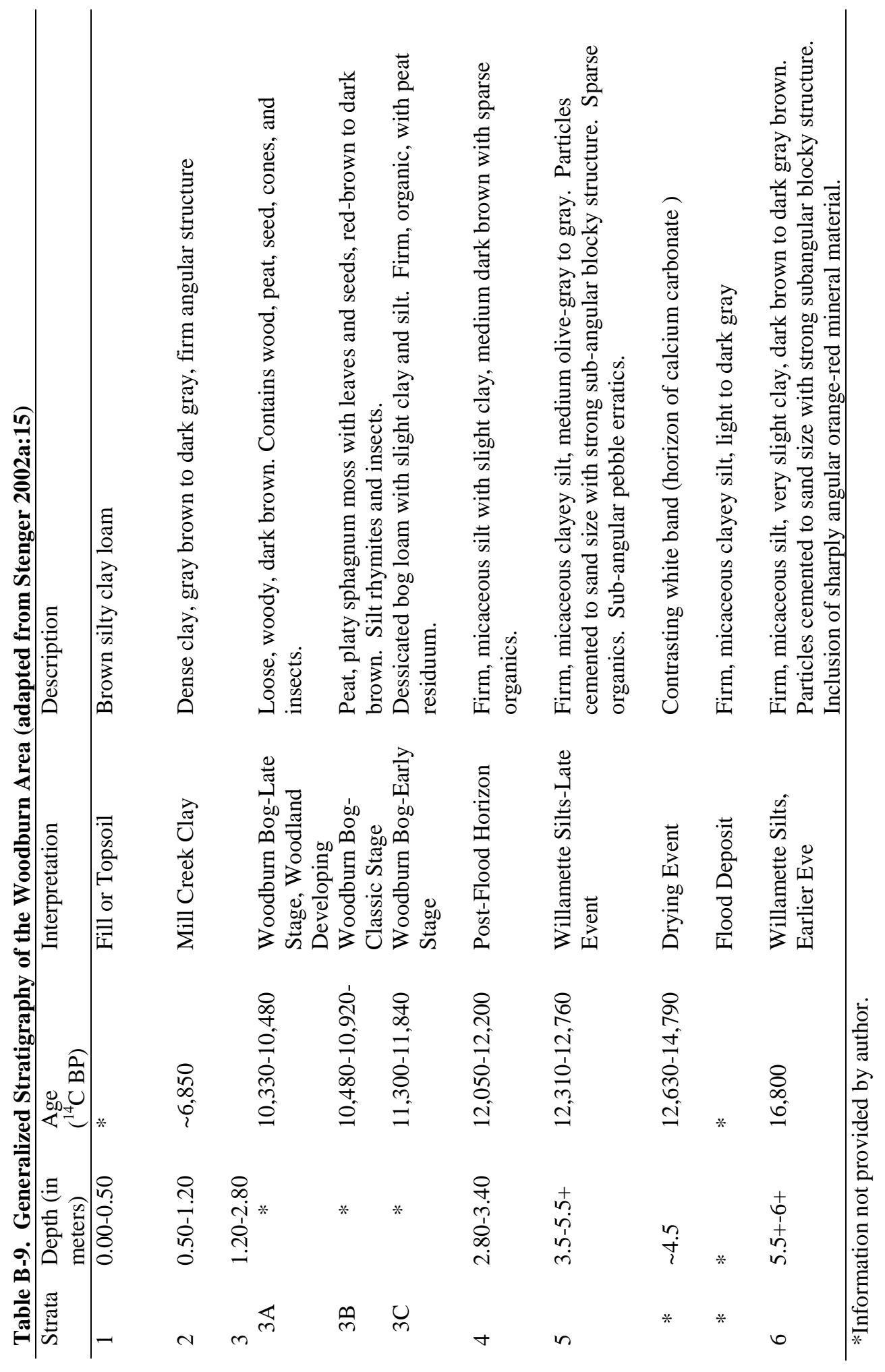


Table B-10. Geologic Context of Woodburn- Legion Park Specimens included in this Study

\begin{tabular}{|c|c|c|c|c|c|c|c|}
\hline $\begin{array}{l}\text { UO MNCH } \\
\text { Designation }\end{array}$ & Genera & Element & Trench & Stratum & Description & Reference & Comment \\
\hline F-37000 & Equus sp. & $\begin{array}{l}\text { terminal } \\
\text { phalange }\end{array}$ & 26-VVI & $3 c / 4$ & $\begin{array}{l}\text { Bog-early } \\
\text { stage or post- } \\
\text { flood horizon }\end{array}$ & $\begin{array}{l}\text { Stenger } \\
2003\end{array}$ & \\
\hline F-38518 & Equus sp. & $\begin{array}{l}\text { right } \\
\text { astragalus }\end{array}$ & 8-P & $3 c / 4$ & $\begin{array}{l}\text { Bog-early } \\
\text { stage or post- } \\
\text { flood horizon }\end{array}$ & $\begin{array}{l}\text { Stenger } \\
2003\end{array}$ & \\
\hline F-38522 & Bison sp. & $\begin{array}{l}\text { left } 2^{\text {nd }} \\
\text { phalanx }\end{array}$ & $6-\mathrm{N}$ & $3 c$ & $\begin{array}{l}\text { Bog-early } \\
\text { stage }\end{array}$ & $\begin{array}{l}\text { Stenger } \\
2003\end{array}$ & \\
\hline F-40523 & Bison sp. & $\begin{array}{l}\text { right } \\
\text { mandible }\end{array}$ & $\begin{array}{l}\mathrm{T}-3 \& \\
\mathrm{~T}-4\end{array}$ & $\begin{array}{l}3 c / 5 \& \\
3 c / 4\end{array}$ & $\begin{array}{l}\text { Bog/pre- } \\
\text { bog/flood } \\
\text { silts }\end{array}$ & $\begin{array}{l}\text { Stenger } \\
2006\end{array}$ & $\begin{array}{l}\text { two } \\
\text { specimens } \\
\text { refit }\end{array}$ \\
\hline F-40527 & Bison sp. & $\begin{array}{l}\text { left } \\
\text { scapula }\end{array}$ & $\begin{array}{l}\mathrm{T}-1 \& \\
\mathrm{~T}-34\end{array}$ & $\begin{array}{l}4 c / 5 \& \\
3 c\end{array}$ & $\begin{array}{l}\text { Bog/pre- } \\
\text { bog/flood } \\
\text { silts }\end{array}$ & $\begin{array}{l}\text { Stenger } \\
2006\end{array}$ & $\begin{array}{l}\text { two } \\
\text { specimens } \\
\text { refit }\end{array}$ \\
\hline
\end{tabular}

A variety of floral and faunal micro- and macro-fossils have been recovered over the years at Legion Park, some of which have been radiocarbon dated (Connolly 2003a; Stenger 1999, 2003:10, 2005:5, 15). Connolly's (2003a) publication is particularly useful as it provides a concise overview of all radiocarbon dates from the various Woodburn backhoe projects, as well as the radiometrically measured ages of all stratigraphically related Willamette Valley peat deposits. My study furnished an additional 15 radiocarbon dates (three measurements per specimen) for Woodburn-Legion Park (Table B-11). Bone chemistry and stable isotopic values were presented in Table 5.4. 
Table B-11. Compilation of Radiocarbon Measurements from Woodburn-Park Area

\begin{tabular}{llllll}
\hline Taxon & $\begin{array}{l}\text { UO MNCH } \\
\text { Designation }\end{array}$ & Lab \# & $\begin{array}{l}\text { Measured } \\
\text { Age }\left({ }^{14} \mathrm{C}\right. \\
\text { BP })\end{array}$ & $\begin{array}{l}\text { Error } \\
\left( \pm{ }^{14} \mathrm{C}\right. \\
\text { age })\end{array}$ & $\begin{array}{l}\text { 2 SD Calibrated } \\
\text { Age Range* } \\
\text { (cal BP) }\end{array}$ \\
\hline $\begin{array}{llll}\text { Equus } \\
\text { sp. }\end{array}$ & F-37000 & UCIAMS78128 & 11,240 & 40 & $13,289-12,963$ \\
& & AA87436u & 11,850 & 110 & $13,934-13,426$ \\
Equus & F-38518 & AA87436 & 11,880 & 120 & $13,985-13,435$ \\
sp. & & UCIAMS78129 & 11,520 & 35 & $13,465-13,268$ \\
& & AA87433u & 11,960 & 230 & $14,832-13,312$ \\
Bison & F-38522 & UCIAMS78130 & 11,035 & 40 & $13,093-12,725$ \\
sp. & & AA87432u & 11,222 & 95 & $13,319-12,841$ \\
& & AA87432 & 11,334 & 98 & $13,420-12,965$ \\
Bison & F-40523 & UCIAMS78131 & 12,175 & 35 & $14,175-13,871$ \\
sp. & & A87434u & 12,380 & 110 & $15,014-14,020$ \\
& & AA87434 & 12,480 & 120 & $15,109-14,115$ \\
& & & & & \\
Bison & F-40527 & UCIAMS78132 & 12,295 & 35 & $14,845-13,982$ \\
sp. & & AA87435u & 12,520 & 120 & $15,140-14,145$ \\
& & AA87435 & 12,550 & 120 & $15,170-14,157$ \\
& & & & &
\end{tabular}

*Calibrated using the OxCal 4.1 radiocarbon calibration program (Bronk Ramsey 2010), using the IntCal09 atmospheric data fromReimer et al. (2009). 


\title{
APPENDIX C: Description of Fossil Material
}

Appendix $\mathrm{C}$ describes the fossil material included in this study, including the systematic paleontology, the skeletal elements assigned to each taxonomic category, and the criteria used for identifications.

\author{
Order Artiodactyla \\ Family Bovidae \\ Bison antiquus - Bison
}

\section{Fossil Material:}

Table C-1. Fossil Material assigned to Bison antiquus

\begin{tabular}{|c|c|c|}
\hline Locality & $\begin{array}{l}\text { Museum } \\
\text { designation }\end{array}$ & Skeletal Elements \\
\hline $\begin{array}{l}\text { Hillsboro } \\
\text { (UO 2666 \& } \\
\text { UWBM } \\
\text { C0139) }\end{array}$ & $\begin{array}{l}\text { UO MNCH: F- } \\
\text { 29240, F- } \\
\text { 29244-29246 } \\
\text { UWBM: } 56474\end{array}$ & $\begin{array}{l}\text { UO MNCH: Cranium, cervical vertebra, spinous process of } \\
\text { thoracic vertebra, ischium fragment, fragmented sacrum (body, } \\
\text { partial acetabulum, and acetabular notch), right femur } \\
\text { UWBM: cervical vertebra, neural spine of thoracic vertebra. } \\
\text { Ischium fragment, partial sacrum (body, partial acetabulum, } \\
\text { acetabular notch) }\end{array}$ \\
\hline $\begin{array}{l}\text { Woodburn } \\
\text { High School } \\
\text { (UO 2596) }\end{array}$ & $\begin{array}{l}\text { UO MNCH \# } \\
\text { F-42801 }\end{array}$ & $\begin{array}{l}\text { Cranium, cervical vertebrae, thoracic vertebra } 1-14 \text {, lumbar } \\
\text { vertebrae } 1-5 \text {, four caudal vertebrae, sternum fragments, } \\
\text { innominate, sacrum, right humerus, right radius and ulna, left } \\
\text { humerus, left olecranon process of ulna, right femur, sternum } \\
\text { fragments, right tibia, right metatarsal, right } 1^{\text {st }} \text { phalanx, right } 2^{\text {nd }} \\
\text { phalanx, right } 3^{\text {rd }} \text { phalanx, right tarsal, rib fragments }\end{array}$ \\
\hline $\begin{array}{l}\text { McMinnville } \\
\text { Bison Site }\end{array}$ & $\begin{array}{l}\text { UO MNCH \# } \\
\text { pending }\end{array}$ & Left femur, cervical vertebra \\
\hline
\end{tabular}

\section{Remarks:}

Three of the bovid specimens in this study are assigned to B. antiquus. The specimens are drawn from three paleontological localities: Hillsboro, Woodburn High School, and McMinnville. Identifications are based upon cranial biometrics and horn core character as established by McDonald (1981) and Skinner and Kaisen (1947) or limb bone biometrics set forth by McDonald (1981). 
A variety of fossil bovid material was recovered at the Hillsboro Locality (UO 2666/UWBM C0139). Specimens assigned to B. antiquus by Kittleman (1977) were a cranium, left pelvis, sacrum, and right femur. I failed to relocate the left pelvis and sacrum at the UO MNCH during an inspection of the UO MNCH's paleontological collections. In addition, Kittleman's inventory also listed five rib fragments and four vertebra fragments assigned to "? Bison antiquus." These could not be relocated either. Furthermore, all record of the Hillsboro Bison material has been expunged from the UO MNCH database. These omissions are perhaps explained by the lack of institutional support for the UO MNCH over the years. The specimens curated at the UWBM are listed as "Bison sp." in the UWBM catalogue. I include them under B. antiquus as the sub-generic classification for this specimen was based on the characteristics of the cranium, which the UWBM researchers did not have access to.

In order to taxonomically identify the bison material, Kittleman collaborated with Dr. S. David Webb, then curator of vertebrate paleontology at the Florida State Museum at the University of Florida. Based upon a series of six cranial and horn core measurements and two derived measures, Dr. Webb assigned the bison cranium to $B$. antiquus (Webb 1975). In four of Webb's measures, the Hillsboro Bison fell within the expected range for B. antiquus. In two other metric attributes, Webb noted that the Hillsboro Bison actually exceeded the range for B. antiquus, but nonetheless was indicative of no species other than B. antiquus. As it had been decades since Webb determined the species of the Hillsboro Bison, I sought to confirm his diagnosis.

The cranium (F-29240) of the Hillsboro Bison was sampled as part of the specialized analyses of this thesis. It consists of the cranium with both horn cores intact 
and largely undamaged. The horn cores are less massive in appearance than would be anticipated for a large, long-horned species of extinct Bison (e.g., Bison latifrons) and are similar in character to comparable published descriptions and illustrations of B. antiquus (McDonald 1981; Skinner and Kaissen 1947). Furthermore, the frontals are proximally depressed and the horn cores are laterally directed from the frontal, rather than sweeping caudally as in species of Bison other than B. antiquus (McDonald 1981:77). When cranial biometric standards put forth by McDonald (1981:38-131) were applied, the specimen again fell within range of $B$. antiquus (see Table E-1 in Appendix E). Given the above, I assign this bison cranium (F-29240) to B. antiquus.

The fossil material recovered from the Woodburn High School Locality (UO 2596) consists of the partial skeleton of a single individual of a large bovid. A preliminary study suggested this animal was B. antiquus (Ellingson and Davis 2009). In order to confirm this identification, I applied the series of measurements to the bison cranium as directed by McDonald (1981) and compared it to published descriptions and illustrations of B. antiquus (Skinner and Kaissen 1947). The frontals are proximally depressed and the horn cores are laterally directed from the frontal, both indications of $B$. antiquus (McDonald 1981:77). Moreover, the horn cores are less massive in appearance than would be anticipated for a larger, long-horned species of extinct Bison (e.g., Bison latifrons) and are similar in character to comparable published descriptions and illustrations of B. antiquus (McDonald 1981; Skinner and Kaissen 1947). Metrically, the fossil cranium is within McDonald's (1981:38-131) range of B. antiquus (see Table E-2 in Appendix E). Given the character of the cranium, the Woodburn High School Bison (F-42801) is assigned to B. antiquus. 
The McMinnville Bison (UO MNCH \# pending) consists of the diaphysis (shaft) and proximal portion of a femur. The greater trochanter has been completely reduced by carnivore gnawing. Stenger and Fitzsimons (2007:5) assigned this specimen as $B$. antiquus, but offer no rationale for the assignment. Morphologically, the femur compared favorably with comparative bovid (B. bison and Bos taurus) material at PSU. In order to increase confidence in the sub-generic identification, I applied two metric measurements of the diameter of the diaphysis following McDonald (1981:44-51). I was not able to apply the third measure (length of the bone) set forth by McDonald as the proximal portion of the skeletal element is not present. Both measures fell in an ambiguous zone, indicating two potential candidate species, B. antiquus and B. bison. However, the AMS date associated with this specimen returned an infinite age. As $B$. bison did not appear until the end Pleistocene, by default the McMinnville Bison femur is assigned to B. antiquus.

\author{
Order Artiodactyla \\ Family Bovidae \\ Bison sp. - Bison
}

\title{
Fossil Material:
}

Table C-2. Fossil Material assigned to Bison sp.

\begin{tabular}{lll}
\hline Locality & $\begin{array}{l}\text { UO MNCH } \\
\text { designation }\end{array}$ & Skeletal Elements \\
\hline Woodburn-Legion Park (UO 3038 \& 3064) & F-38522 & Left $2^{\text {nd }}$ phalanx \\
& F-40523 & Right mandible \\
& F-40527 & Left scapula \\
\hline
\end{tabular}

\section{Remarks:}

Three bovid specimens recovered from the Woodburn-Legion Park localities (UO 3038 \& 3064) were included in this study. As is the case with most of the fossil material 
recovered from the Willamette Valley, documentation is sparse. Stenger $(2003,2006)$ prepared reports in which she referred to potential taxa represented but did not systematically identify any of the fossil material. Stenger travelled with the fossil materials to the Page Museum of the La Brea Tar Pits (Los Angeles, CA) to consult with a staff paleontologist. According to the UOMNCH database, the Page Museum paleontologist assigned the materials to B. antiquus. However, no documentation exists to support these assignments. In an email exchange, Stenger informed me that the Woodburn specimens were identified as a favor to her and that no report was prepared (Alison T. Stenger, personal communication 2010). Given the lack of documentation for the Woodburn-Legion Park fauna, I could only consider the taxonomic identifications as tentative and in need of confirmation.

Woodburn-Legion Park specimen \# F-38522 is a complete left $2^{\text {nd }}$, or medial, phalanx, previously assigned to $B$. antiquus. It is clearly a bison phalanx based on gross morphology. Unfortunately, this element is generally not referable to a taxonomic level finer than genus (e.g., Hill et al. 2005:87). As such, I assign it to Bison sp.

Woodburn-Legion Park specimen \# F-40523 is a fragment of a right mandible. It is represented by the ascending ramus, ventral most portion of the coronoid process, superior (mandibular) notch, and the ventral most portion of the condyloid process. As with the other Woodburn-Legion Park materials, this specimen was previously assigned to $B$. antiquus by paleontologists at the Page Museum but there is no documentation to support this assertion. This specimen was compared to other fossil and comparative bison material at the UO MNCH by myself and Dr. Edward Byrd Davis, fossil collections 
manager at the UO MNCH. It compares well with Bison, however, given the limited portion of the element present, its systematic placement remains at the level of genus.

Woodburn-Legion Park specimen \# F-40527 is a small, fragmented left scapula. This scapula was previously designated as a juvenile $B$. antiquus by staff at the Page Museum. It is represented by a medial portion of the scapular spine, the infraspinous fossa, and the supraspinous fossa. The entire ventral portion of the scapula, to include the glenoid fossa, coracoid process, and acromion process, are not present. These are portions of the scapula usually considered to be more diagnostic in most fauna. Moreover, the dorsal portion of the element is also missing. This scapula was compared to other fossil and comparative bison material by myself and Dr. Edward Byrd Davis, the fossil collections manager at the $\mathrm{UO} \mathrm{MNCH}$. We jointly concluded that this specimen is a fragment of the scapula of a small bison. Given the limited portion of the element present, we could not assign it with confidence beyond genera. As such, it is assigned to Bison sp.

$$
\begin{aligned}
& \text { Order Perissodactyla } \\
& \text { Family Equidae } \\
& \text { Equus sp.- horses }
\end{aligned}
$$

\section{Materials:}

Table C-3. Fossil Material assigned to Equus sp.

\begin{tabular}{lll}
\hline Locality & $\begin{array}{l}\text { UO MNCH } \\
\text { designation }\end{array}$ & Skeletal Elements \\
\hline Woodburn-Legion Park (UO 3867) & F-37000 & Terminal (3 ${ }^{\text {rd }}$ ) phalanx \\
Woodburn-Legion Park (UO 3038) & F-38518 & Right astragalus \\
\hline
\end{tabular}




\section{Remarks:}

Two equid specimens are included in this study. Both were recovered in the previously discussed Woodburn-Legion Park backhoe investigations. Both these specimens were previously identified as Equus occidentalis by staff at the Page Museum. However, there is only minimal documentation to support this assertion. Both of the specimens are complete or nearly complete elements. As such, taxonomic identification of each specimen could be attempted via metric methods. Measurements followed the guidelines set forth in published guides and were compared to metric data compiled by Eric Scott, curator of paleontology at the San Bernardino County Museum of Natural History.

Specimen \# F-38518 is a complete right astragalus. The measures applied to this specimen were set forth by Eisenmann et al (1988:56-57). Based upon comparison with metric data compiled by Eric Scott, this specimen is from a very large individual. It is the size of either the large Equus occidentalis as known at Rancho La Brea or Equus pacificus, which is possibly a northern size morph of Equus scotti (Eric Scott, personal communication 2011). However, given a lack of additional diagnostic characters, it is assigned to Equus sp.

Specimen \# F-37000 is a third, or terminal, phalanx. The procedures applied to this specimen were those set forth Eisenmann et al (1988:68-69). Based upon comparison with metric data compiled by Eric Scott, this specimen is from a very large individual, though not as large as the previously discussed horse astragalus. The measurements fall within range of two late Pleistocene horses, Equus pacificus and Equus scotti as known from the type locality, Rock Creek (Eric Scott, personal 
communication 2011). However, given a lack of additional diagnostic characters, it is assigned to Equus sp.

\author{
Order Pilosa \\ Family Mylodontidae \\ Paramylodon harlani (Harlan's Ground Sloth)
}

\title{
Materials:
}

Table C-4. Fossil Material assigned to Paramylodon harlani

\begin{tabular}{lll}
\hline Locality & $\begin{array}{l}\text { Museum } \\
\text { Designation }\end{array}$ & Skeletal Elements \\
\hline Hillsboro (UO 2666) & $\begin{array}{l}\text { UO MNCH: F- } \\
29242\end{array}$ & Right femur, left humerus \\
& UWBM: 56473 & $\begin{array}{l}\text { Right mandible, jugal atlas, } \\
\text { right fibula, caudal } \\
\text { vertebra, thoracic vertebra, } \\
\text { lumbar vertebra, and 15 } \\
\text { unidentified fragments }\end{array}$ \\
$\begin{array}{l}\text { Tualatin River-Fanno Creek } \\
\text { (locality \# pending) }\end{array}$ & $\begin{array}{l}\text { UO MNCH \# } \\
\text { pending }\end{array}$ & $\begin{array}{l}\text { Synsacrum with attached } \\
\text { lumbar vertebra }\end{array}$ \\
$\begin{array}{l}\text { McMinnville Sloth Site } \\
\text { (locality \# pending) }\end{array}$ & $\begin{array}{l}\text { UO MNCH \# } \\
\text { pending }\end{array}$ & Right humerus \\
\hline
\end{tabular}

\section{Remarks:}

Three sloth specimens, from three separate paleontological localities, are included in this study. There were three species of giant sloths present in North America during the late Pleistocene, P. harlani, Nothrotheriops shastensis, and Megalonyx Jeffersoni. Stock (1925) put forth descriptions of the osteology of the extinct, giant ground sloths based on a large sample from Rancho La Brea. All three specimens included in this study compare well with $P$. harlani.

Two elements of a sloth, a complete right femur and a left humerus, were recovered from the Hillsboro Locality (UO 2666). The femur was sampled for this thesis. In order to establish the taxonomy of the sloth elements, Kittlemen consulted Dr. 
William Akersten, then curator of the Page Museum at the Rancho La Brea Tar Pits of the Los Angeles County Museum of Natural History. Based upon photographs of the sloth femur and humerus provided by Kittleman, Akersten (1976) established the species of both specimens to be P. harlani. I too compared both elements to Stock's (1925) seminal manuscript on the osteology of extinct Xenarthran sloths and it compares favorably to Paramylodon. Specifically, of the three species of giant ground sloth in North America in the Pleistocene, both Nothrotheriops or Megalonyx possess a third trochanter on their femur. Only Paramylodon lacks this feature (Kurten and Anderson 1980:144; Stock 1925:171). The Hillsboro Sloth femur is a complete element and lacks a third trochanter. As such, it is readily assigned to P. harlani, Harlan's Ground Sloth. In addition, the sloth humerus from this locality also compares favorably with Paramylodon.

The Tualatin River-Fanno Creek Sloth synsacrum has been the property of the THS for several years. In that time, it was incorrectly identified by unknown persons as the sacrum of an American mastodon (M. americanum) and promoted as such during local celebrations of regional history, on websites, and in the print media. This sloth specimen is the same formerly known locally as the "Fanno Creek-Tualatin River Mastodon" or the "Fanno Creek Mastodon."

In order to increase confidence in this taxonomic identification, I compared it to published illustrations of other late Pleistocene fauna. It did not compare well with any Proboscidean. The literature review was then expanded to include other megafauna. This specimen features the last lumbar vertebra attached to the synsacrum, a condition common in P. harlani (Kurten and Anderson 1980:144; Stock 1925:120, plates 35-37). 
The fossil material was contrasted with published guides outlining the comparative osteology of extinct North American Pleistocene sloths (Stock 1925). It was indicative only of $P$. harlani. Next, I forwarded photographs of this specimen to Dr. Greg McDonald, Senior Curator of Natural History in the Park Museum Management Program of the National Park Service. McDonald also was convinced that the specimen was $P$. harlani (Greg McDonald, personal communication 2010).

The McMinnville Sloth is represented by a right humerus. It is a nearly complete specimen. The distal articular surface is intact, as is the majority of the diaphysis. While the head of the humerus is mostly present, there is attrition on the posterior proximal portion of the articular surface. In addition, the anterior portion of the proximal shaft and the anterior portion of the greater tubercle are not intact.

This specimen was compared to Stock's (1925) monograph. While 3 varieties of sloth are recognized to have existed in the time period of this study, Paramylodon exhibits distinct different osteological traits as compared to either Nothrotheriops or Megalonyx. The humerus of P. harlani is more heavily constructed (Stock 1925:120, 146) and distinctively broadens distally as compared to the other species (Kurten and Anderson 1980:144). Most obviously, the humerus of $P$. harlani lacks the entepicondylar (supracondyloid) foramen superior to the distal articular surface that is present in both other genera (Stock 1925:146). The McMinnville Sloth humerus exhibits each of these traits and is assigned to P. harlani. 


\author{
Order Proboscidea \\ Family Mammutidae \\ Mammut americanum (American mastodon)
}

\title{
Materials:
}

Table C-5. Fossil Material assigned to Mammut americanum

\begin{tabular}{lll}
\hline Locality & $\begin{array}{l}\text { UO MNCH } \\
\text { designation }\end{array}$ & Elements \\
\hline $\begin{array}{l}\text { Tualatin } \\
\text { (UO 2840) }\end{array}$ & F-30282 & $\begin{array}{l}3 \text { molars, cranial fragments, both tusks, cervical vertebra, 21 } \\
\text { vertebra, ribs, left scapula, left humerus, left ulna, carpals, } \\
\text { metacarpals, innominate, pelvic fragments, caudal vertebra, } \\
\text { left femur, left tibia, tarsals, metatarsals }\end{array}$ \\
\hline
\end{tabular}

\section{Remarks:}

The extinct genera in Order Proboscidea are readily recognized from one another by their dentition. While mammoth teeth are characterized as flat grinding surfaces thought to primarily reflect a dietary specialization of grazing (Haynes 1991:6; Webb 1992), mastodon teeth consist of relatively low-crowned molars of parallel rows of nipple shaped cusps (Haynes 1991:4; Tobien 1996). As such, a mastodon is readily differentiated from any mammoth by gross differences in dentition.

Molars are present in the inventory of the Tualatin Mastodon. As there was only a single species from Family Mammutidae in North American in the Pleistocene, the dentition qualifies it as M. americanum, the American mastodon. Each of the other elements also compares favorably with Mammut as per Olsen's (1972) guide to the osteology of Pleistocene Proboscideans.

The Tualatin specimen was recovered during a student led excavation in the 1960s (George and Sund 1962) and is interpreted to represent a single individual. This is supported by multiple lines of evidence. Some photo documentation of the excavation exists. The photos indicate that the axial elements (vertebra) of the Tualatin Mastodon were articulated with the appendicular elements in close proximity. Moreover, there are 
no repeating elements. This supports the concept that only a single individual is

represented and as such, the use of teeth to qualify this specimen taxonomically is valid.

Order Proboscidea

Family Elephantidae - Elephants

Mammuthus columbi - Columbian mammoth

\section{Fossil Material:}

Table C-6. Fossil Material assigned to Mammuthus columbi

\begin{tabular}{lll}
\hline Locality & $\begin{array}{l}\text { UO MNCH } \\
\text { designation }\end{array}$ & Elements \\
\hline $\begin{array}{l}\text { McMinnville } \\
\begin{array}{l}\text { Mammoth Site (UO } \\
3076)\end{array}\end{array}$ & pending & $\begin{array}{l}\text { left tusk, cranial fragments (sinus cavity, zygomatic arch, } \\
\text { septum, 1 indet. frag.), mandibular symphisis, maxilla with } \\
\text { 2 upper right molars, lower left molar, right scapula, left } \\
\text { scapula, left tusk socket, 2 right ribs, left rib, 2 ribs } \\
\text { fragments, } 8 \text { thoracic vertebra }\end{array}$ \\
$\begin{array}{l}\text { Pratum- } \\
\begin{array}{l}\text { Rutschman/Qualey } \\
\text { (UO \# pending) }\end{array}\end{array}$ & pending & $\begin{array}{l}\text { Left upper } 5^{\text {th }} \text { molar, right upper } 5^{\text {th }} \text { molar, fragmented } \\
\text { tusk, left femur, fragmentary pelvis }\end{array}$ \\
\hline
\end{tabular}

\section{Remarks:}

The McMinnville Mammoth was originally described by Bonnichsen et al. (2002) in a conference paper. All of the mammoth remains are considered to represent a single individual. To determine the species of the McMinnville Mammoth, Bonnichsen et al. (2002) worked with Dr. Russell W. Graham, then of the Denver Museum of Natural History, sending Graham digital photographs of the lingual and buccal sides and occlusal surface of the upper and lower molars for calculation of lamellar frequencies.

Bonnichsen et al. reported that Graham identified that the upper tooth had a lamellar frequency of five, while the lower tooth had a lamellar frequency of six. Based upon this data, Bonnichsen et al., with direction from Graham, determined the specimen was from to $M$. columbi. 
Unfortunately, the data accumulated by Bonnichsen et al. (2002) was not published. Moreover, I exchanged emails with Graham (Russel W. Graham, personal communication 2010) over the matter. Graham remembered years earlier offering his expertise to aid Bonnichsen in identifying the mammoth but prepared no documentation himself. As such, I considered the taxonomic identification tentative.

In order to increase confidence, I applied the osteometric criteria set forth by Graham (1986a, b) and Madden (1995) for speciation of mammoths based upon dental characteristics of the molars (see Appendix E). Based on measures of the length and width of each molar, lamellar frequency, mean enamel thickness, and number of plates, the McMinnville Mammoth was assigned to Mammuthus columbi.

Barton and Cearley (2008) and Cearley (2008) analyzed the PRQ Mammoth. They identified the taxa based on gross morphology of the molars and morphometric analysis of the width and enamel thickness of the molars, in conjunction with lamellar frequencies. In the late Pleistocene, there were two candidate species for this specimen, M. columbi and M. primigenius (Agenbroad 2005). Barton and Cearly stated that the width and enamel thickness exceed those known for M. primigenius. Moreover, the lamellar frequency also failed to meet expectations for that species. Lastly, the height of the molars (165 $\mathrm{mm}$ and $140 \mathrm{~mm}$ ) exceeded the value for all species of mammoth except M. columbi. The PRQ molars were therefore identified as a Columbian mammoth ( $M$. columbi). As the locality was interpreted as representing only a single individual, the rest of the osteological materials were also assigned to M. columbi. 
Order Proboscidea

Family Elephantidae - Elephants

Mammuthus sp. - mammoths

\section{Fossil Material:}

\begin{tabular}{lll} 
Table C-7. & Fossil Material assigned to Mammuthus columbi \\
\hline Locality & $\begin{array}{l}\text { Museum } \\
\text { designation }\end{array}$ & Elements \\
\hline $\begin{array}{l}\text { Hillsboro } \\
\text { (UO \# }\end{array}$ & MNCH: & $\begin{array}{l}\text { cranium, left tibia, right tibia, right fibula, right calcaneum, caput of } \\
\text { femur, left scapula, right scapula, right ulna, right radius, 30 ribs, } 15\end{array}$ \\
$\begin{array}{l}\text { 2666 \& } \\
\text { UWBM \# }\end{array}$ & F-29247 & vertebra, 16 intervertebral discs, 10 phalanges, 16 podial elements \\
C0139) & UWBM: & mandible fragment, maxilla fragment, vertebral disk \\
& 56475 & \\
\hline
\end{tabular}

\section{Remarks:}

As discussed in Appendix B, the report documenting the findings of investigations at the Hillsboro Locality is missing from the $\mathrm{UO} \mathrm{MNCH}$ and no copy is known to exist. Based on the available documentation provided by Laurence R.

Kittleman (former director of the UO MNCH in the 1970s), the elephantid materials from Hillsboro were assigned to Mammuthus sp., ostensibly based on gross morphology. The same conclusion was also reached by researchers from the University of Washington, although the only record that remains from their study of the Hillsboro Locality is the database entry/catalogue card on file at the UWBM (Barnosky 1978).

The immense size of the fossil material coupled with the age of the geologic stratum from which it was recovered (final millennia of the Pleistocene) indicates that the animal is a Proboscidean. The elements compare favorably to published guides of mammoth osteology (Olsen 1972). Although other taxa were recovered from this paleontological locality, the mammoth remains were interpreted as the remains of a single individual animal. 
Sub-generic taxonomic identifications for the genus Mammuthus are predominantly based upon dentition. While a significant portion of the Hillsboro Mammoth (including the cranium) was recovered, teeth were not present. As such, Mammuthus sp. is the finest taxonomic category to which this specimen can be confidently assigned. 


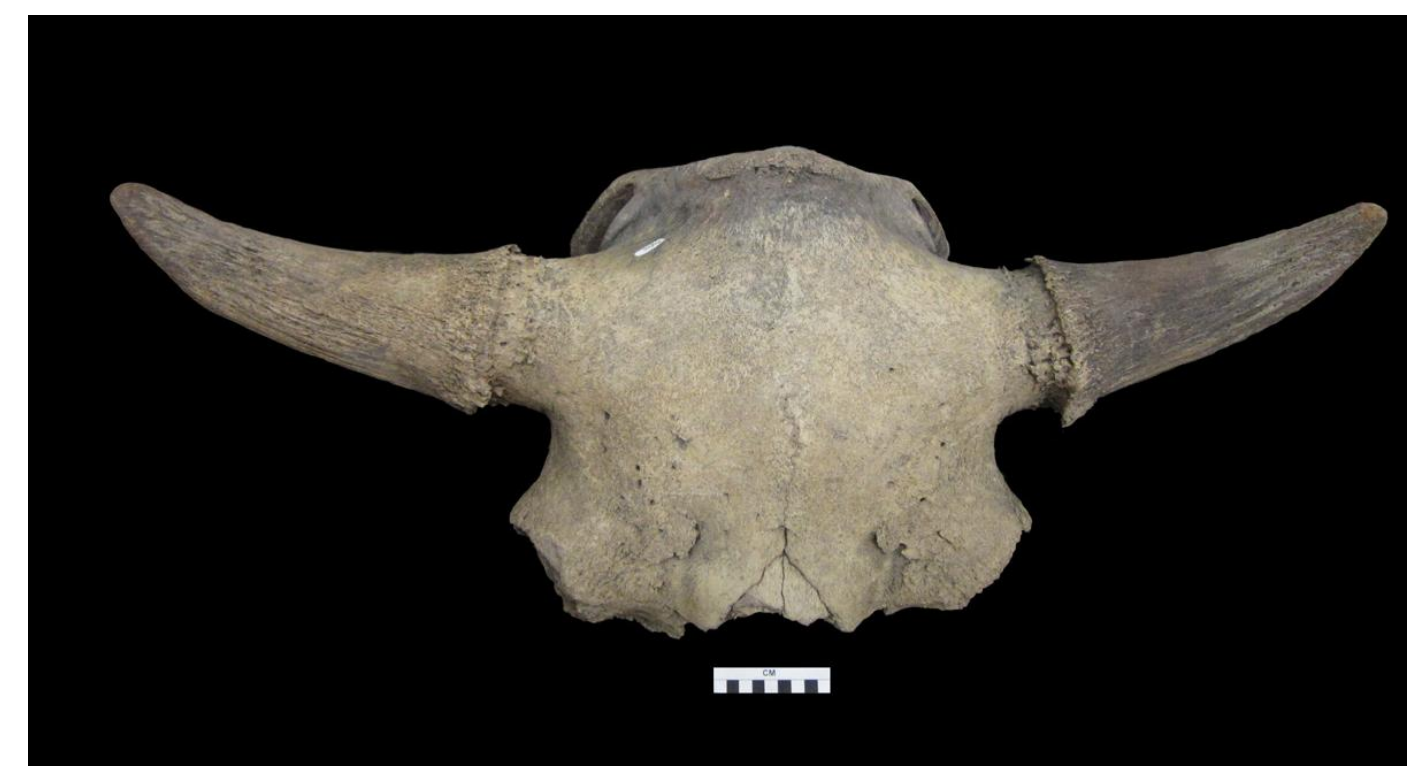

Figure D-1. Dorsal view of cranium of Hillsboro Bison antiquus (UO MNCH \# F-29240)

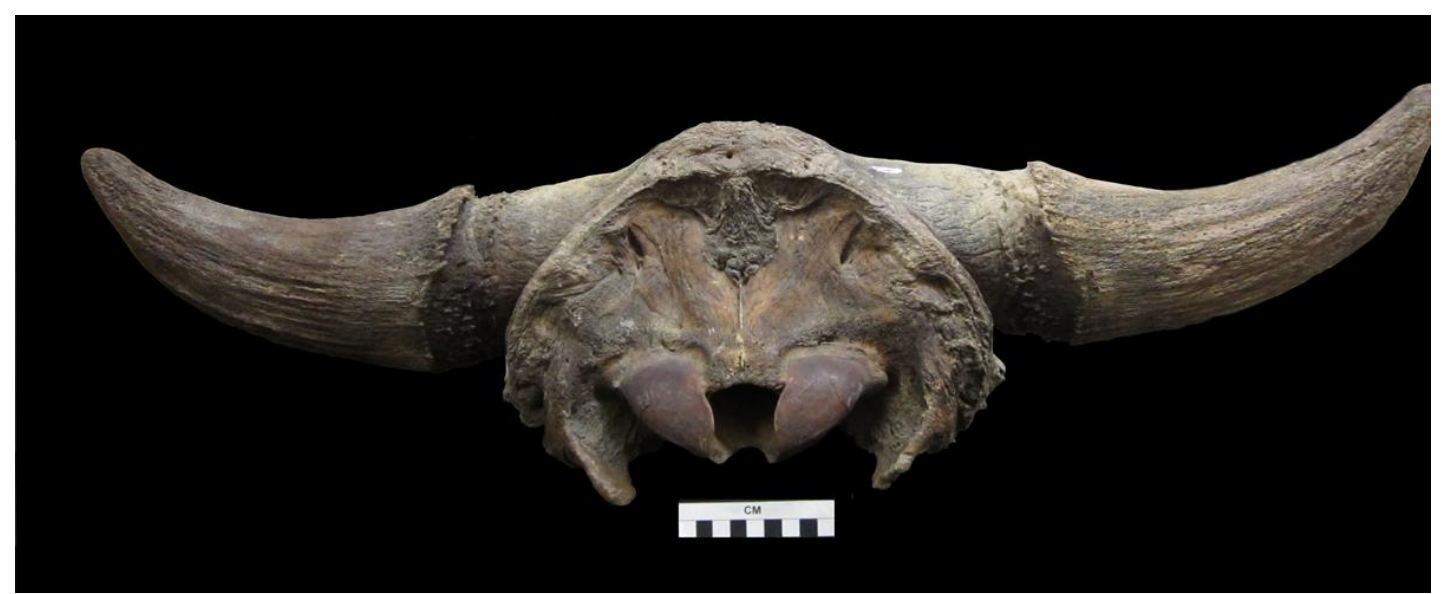

Figure D-2. Posterior view of cranium of Hillsboro Bison antiquus (UO MNCH \# F-29240) 


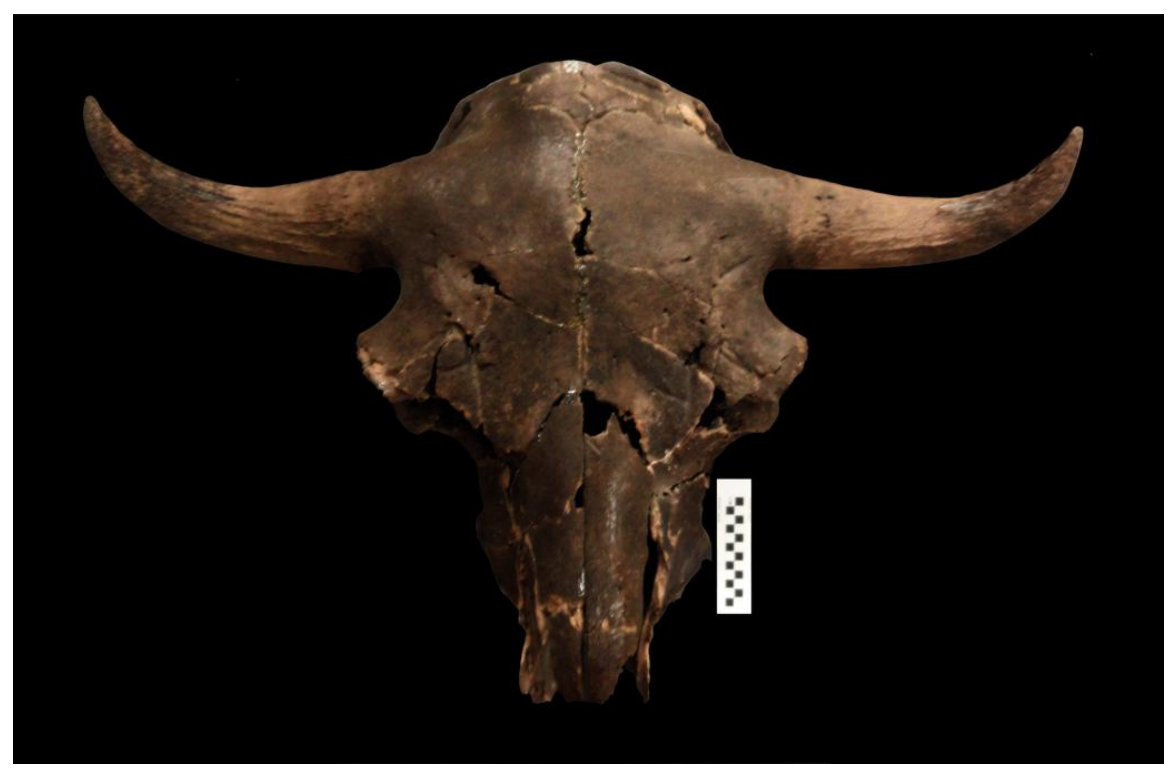

Figure D-3. Dorsal view of cranium of Woodburn High School Bison antiquus (UO MNCH \# F-42801)

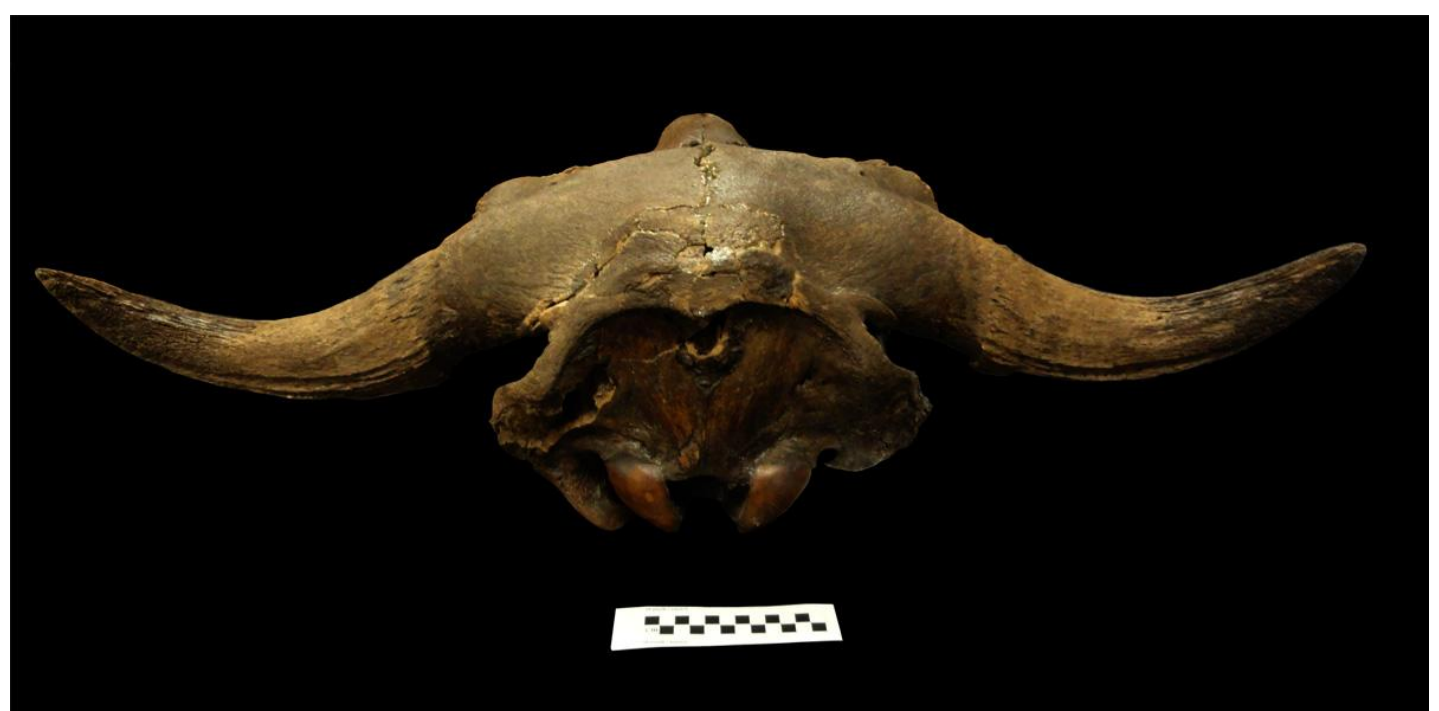

Figure D-4. Posterior view of cranium of Woodburn High School Bison antiquus (UO MNCH \# F-42801) 


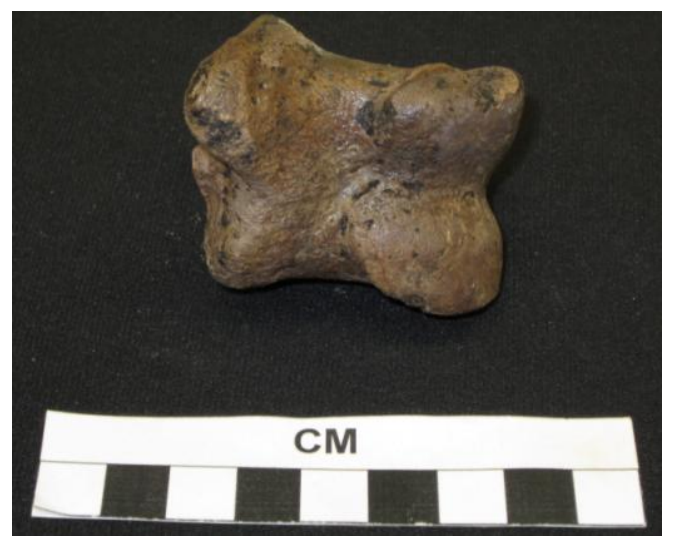

Figure D-5. Ventral view of left $2^{\text {nd }}$ phalanx of Woodburn-Legion Park Bison sp. (UO MNCH \# F-38522

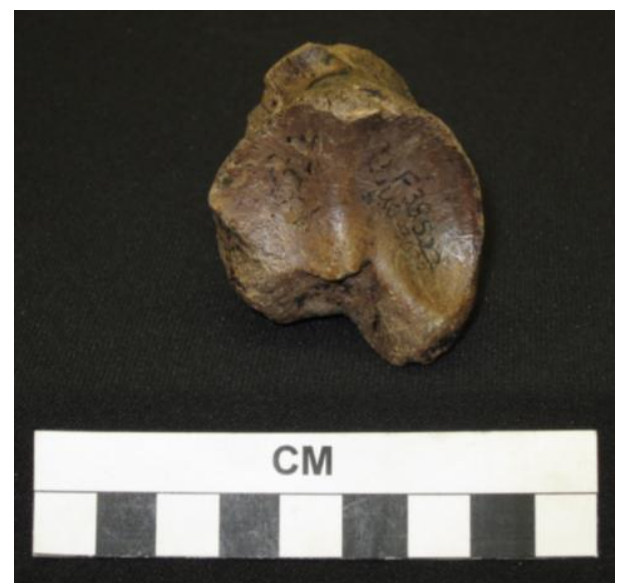

Figure D-6. Posterior view of left $2^{\text {nd }}$ phalanx of Hillsboro Bison sp. (UO MNCH \# F-38522)

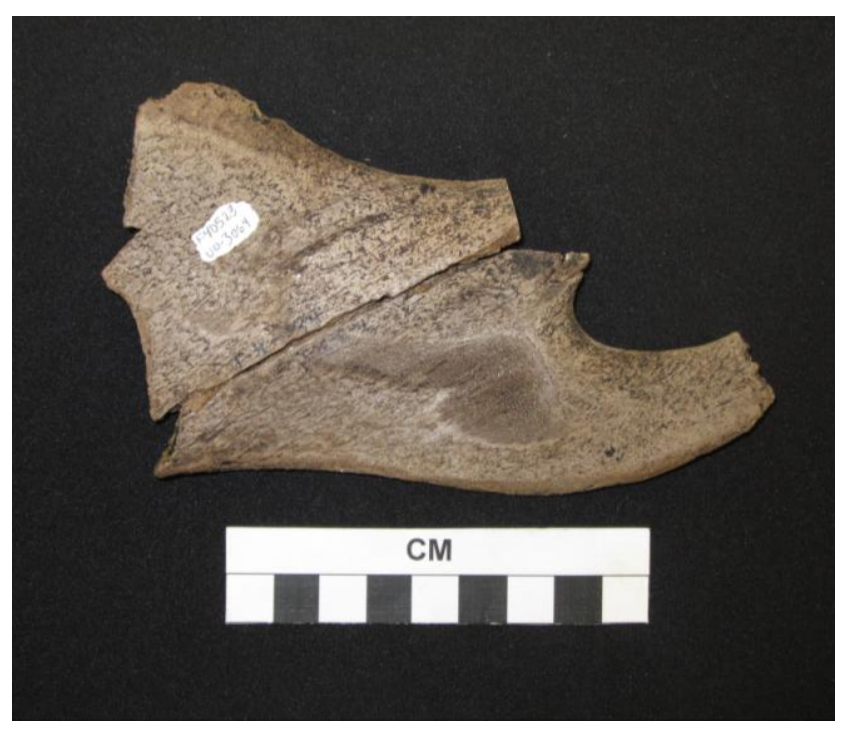

Figure D-7. Medial view of right mandible of WoodburnLegion Park Bison sp. (UO MNCH \# F-40523)

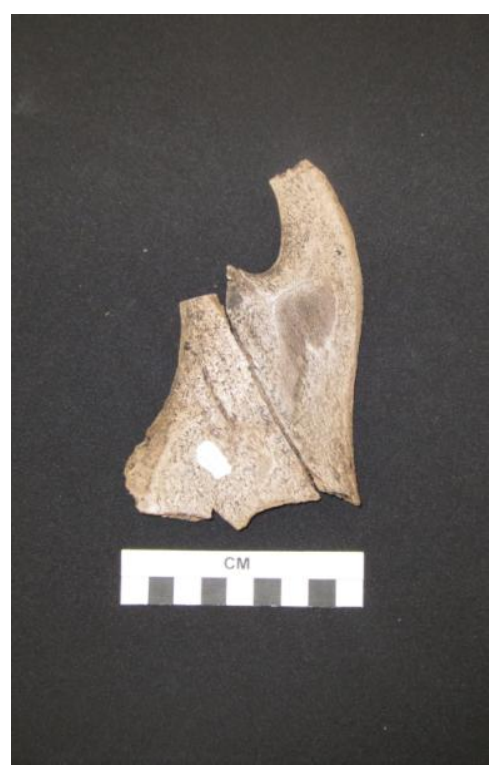

Figure D-8. Alternate angle of medial view of right mandible of Woodburn-Legion Park Bison sp. (UO MNCH \# F-40523) 


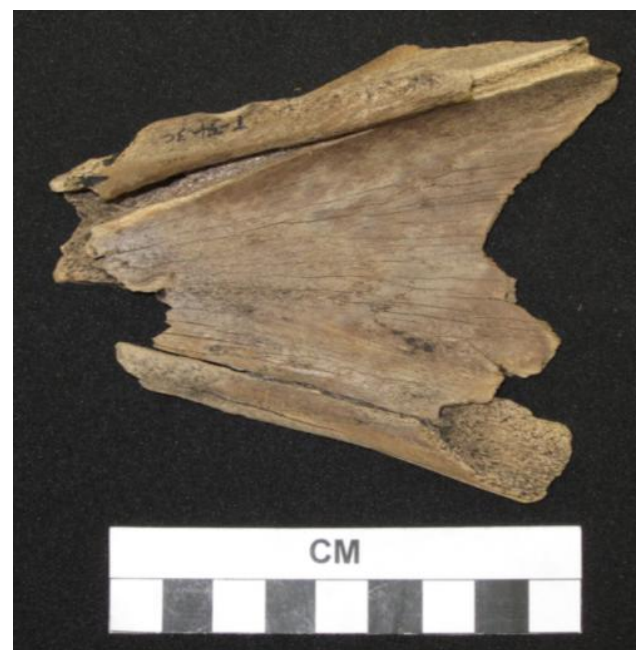

Figure D-9. Dorsal view of left scapula of Woodburn-Legion Park Bison sp. (UO MNCH \# F-40527).

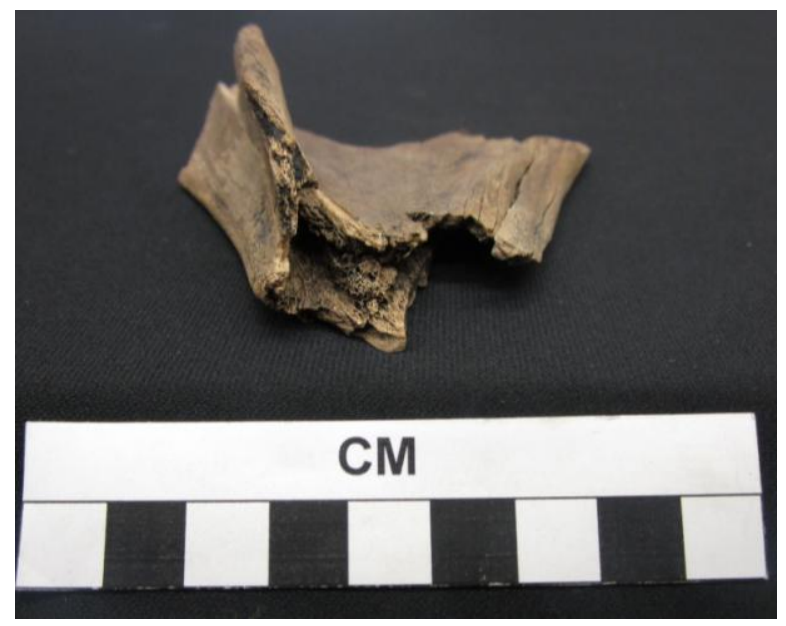

Figure D-10. Anterior view of left scapula of Woodburn-Legion Park Bison sp. (UO MNCH \# F40527). Note the position of the scale bar (closer to the camera) anterior to the fossil has skewed (made the fossil look smaller) the scale of the photo.

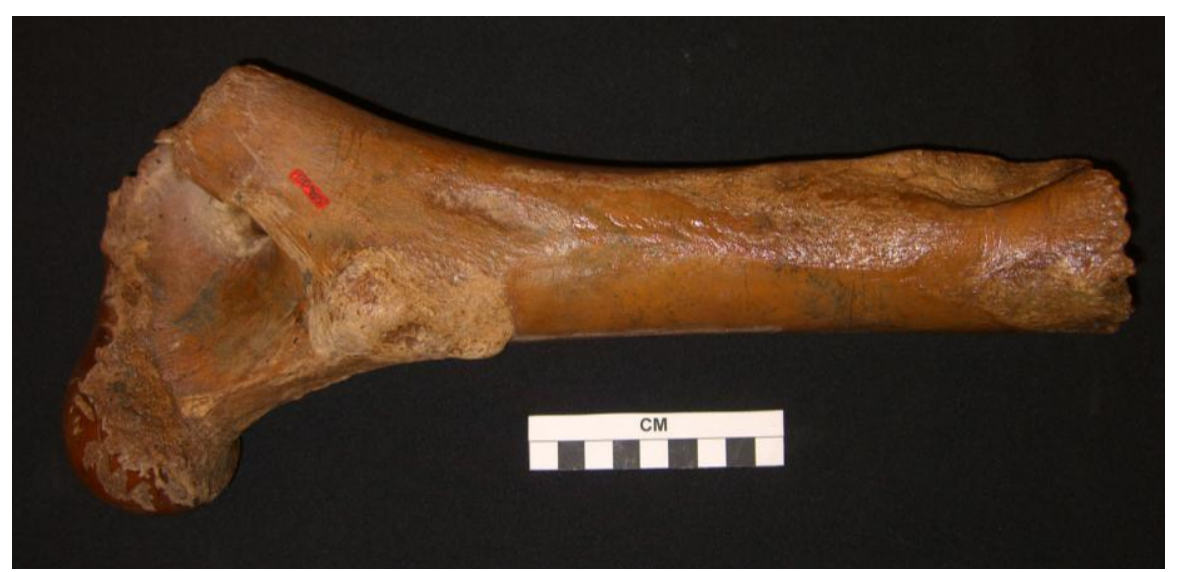

Figure D-11. Posterior view of right femur of McMinville Bison anitquus (UO MNCH \# pending).

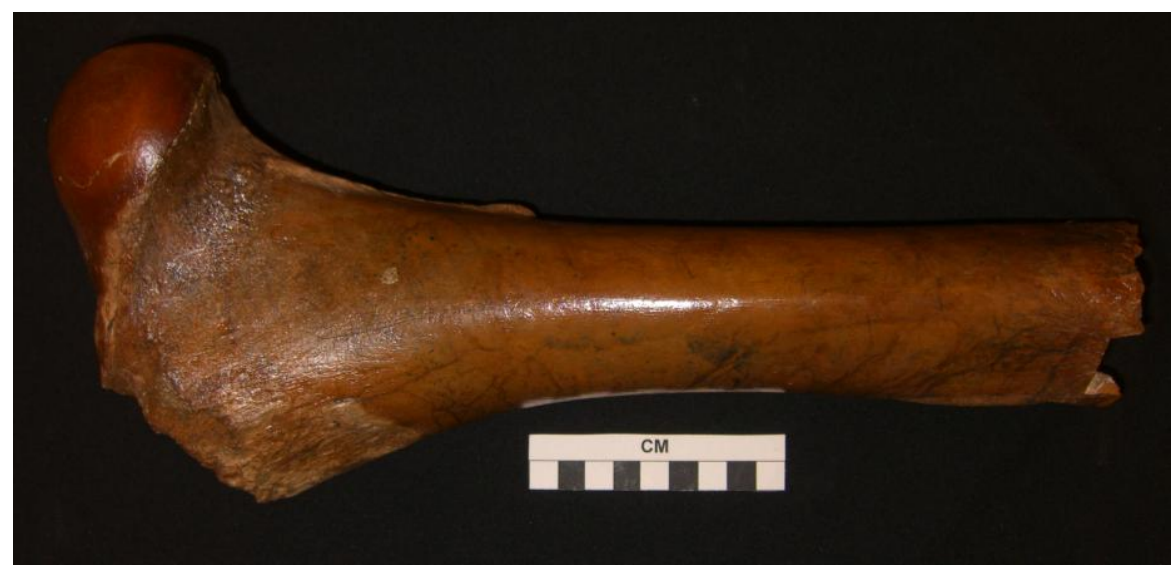

Figure D-12. Anterior view of right femur of McMinville Bison anitquus (UO MNCH \# pending). 


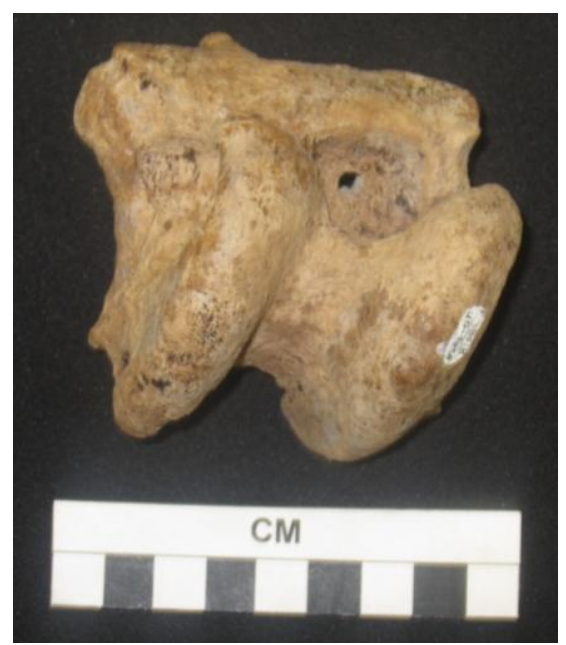

Figure D-13. Dorsal view of right astragalus of Woodburn-Legion Park Equus sp. (UO MNCH \# F-38518).

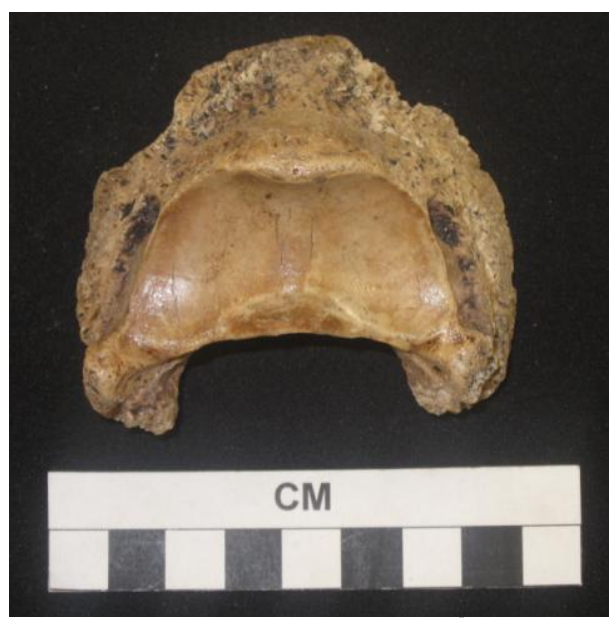

Figure D-15 Dorsal view of $3^{\text {rd }}$ phalanx of Woodburn-Legion Park Equus sp.

(UO MNCH \# F-37000).

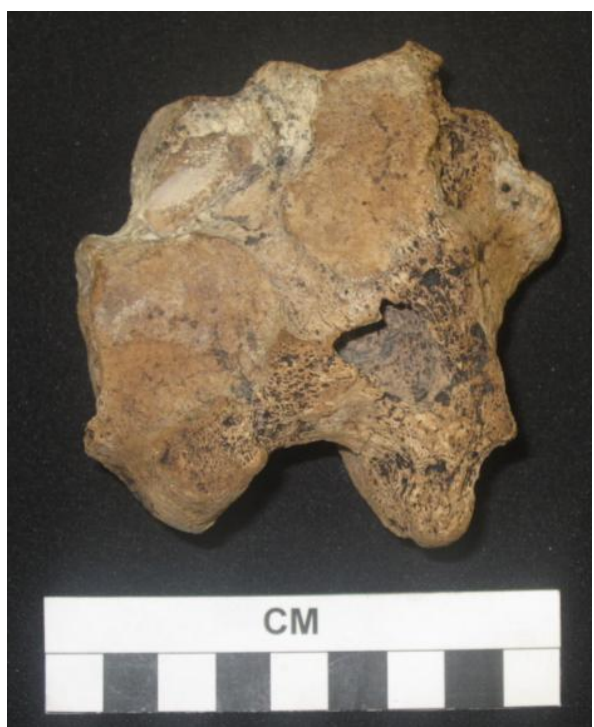

Figure D-14. Ventral view of right astragalus of Woodburn-Legion Park Equus sp. (UO MNCH \# F-38518).

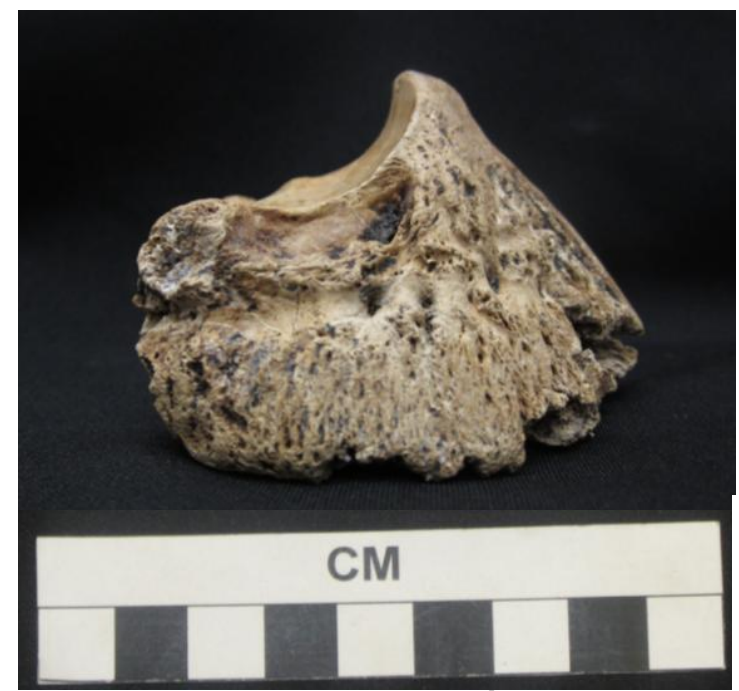

Figure D-16. Lateral view of $3^{\text {rd }}$ phalanx of Woodburn-Legion Park Equus sp. (UO MNCH \# F-37000). 


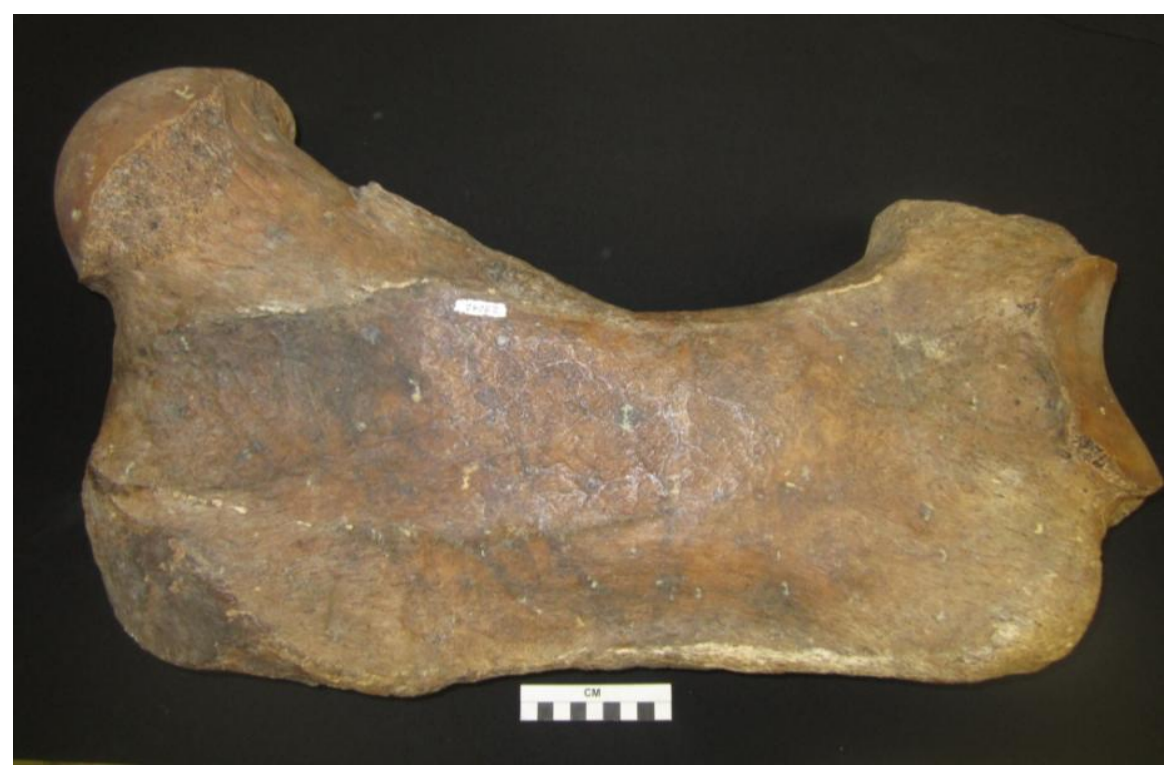

Figure D-17. Anterior view of right femur of Hillsboro Paramylodon harlani (UO MNCH \# F-29242).

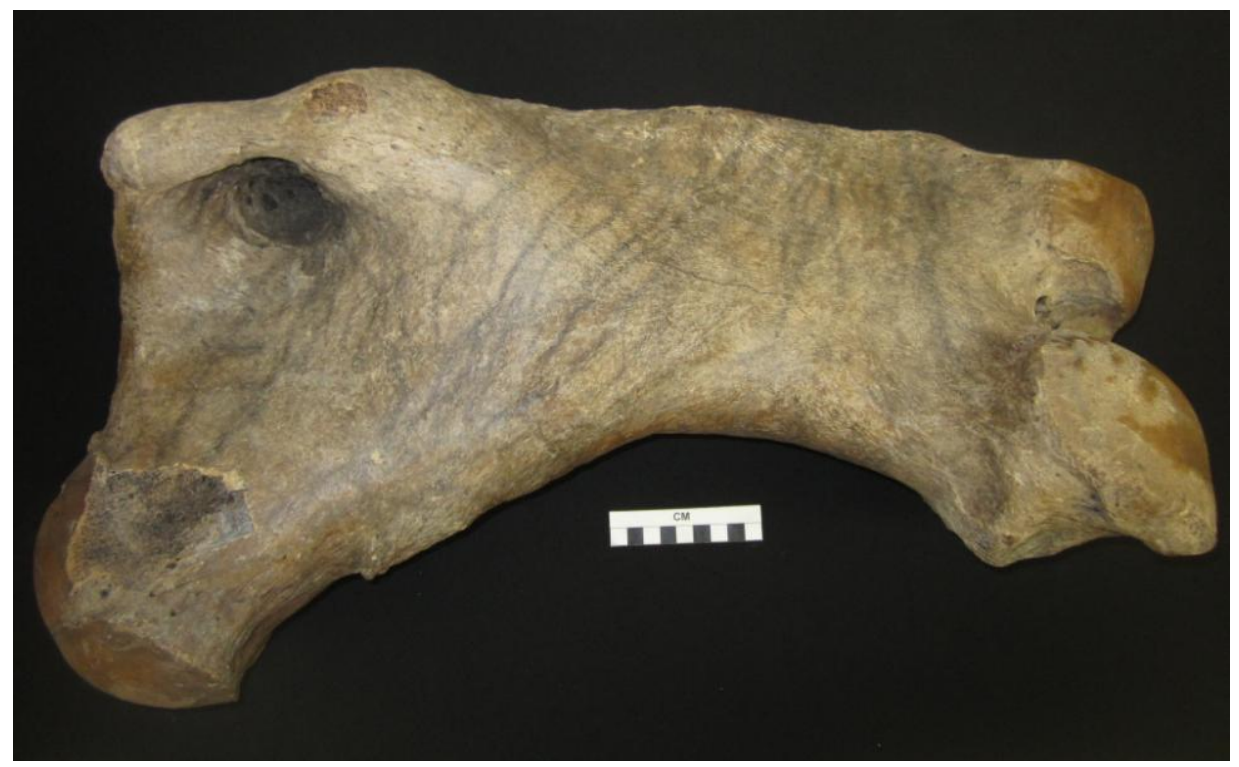

Figure D-18. Posterior view of right femur of Hillsboro Paramylodon harlani (UO MNCH \# F-29242). 


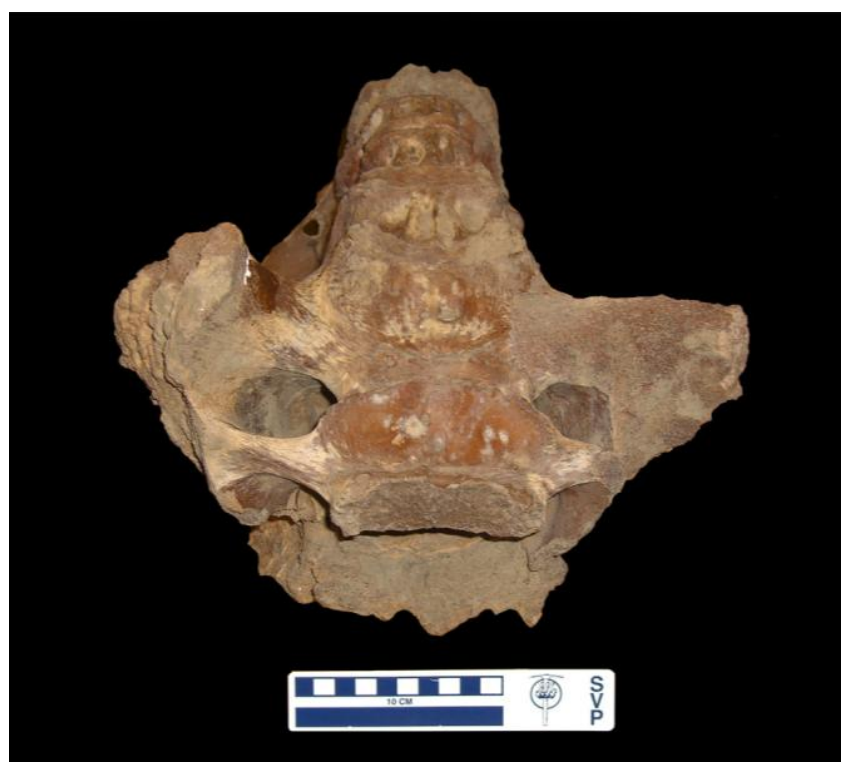

Figure D-19. Caudal view of synsacrum of Tualatin RiverFanno Creek Paramylodon harlani (UO MNCH \# pending).

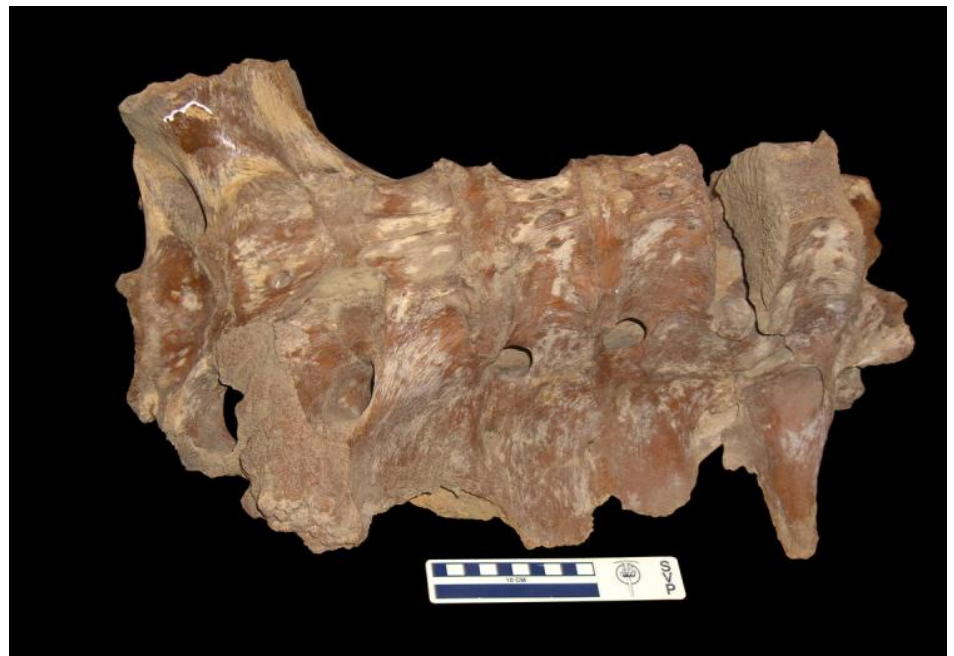

Figure D-20. Lateral view of synsacrum of Tualatin RiverFanno Creek Paramylodon harlani (UO MNCH \# pending). 


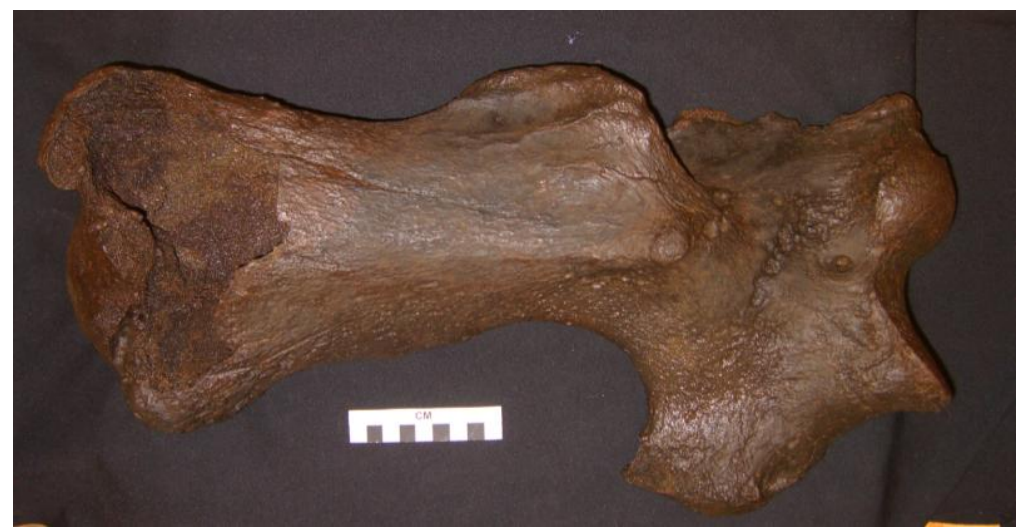

Figure D-21. Anterior view of right humerus of McMinnville Paramylodon harlani (UO MNCH \# pending).

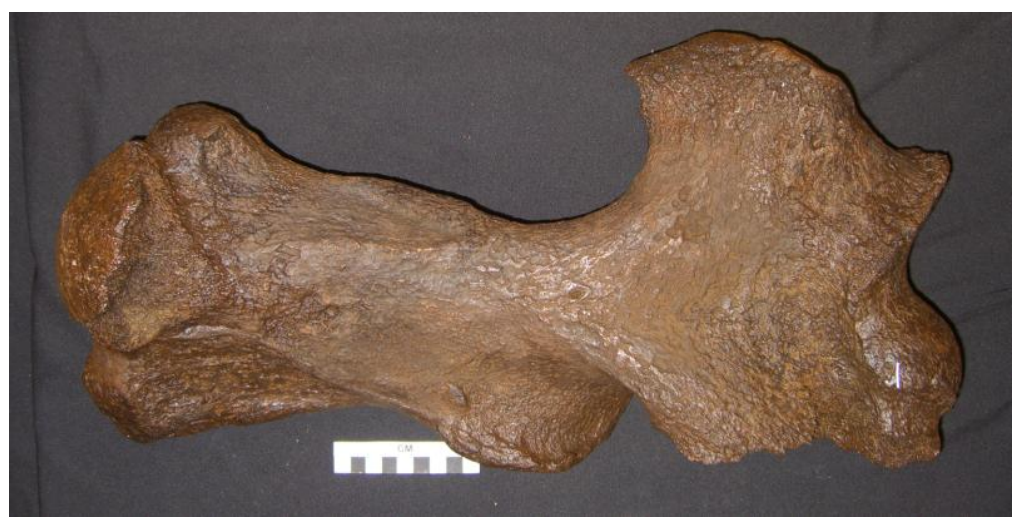

Figure D-22. Posterior view of right humerus of McMinnville Paramylodon harlani (UO MNCH \# pending).

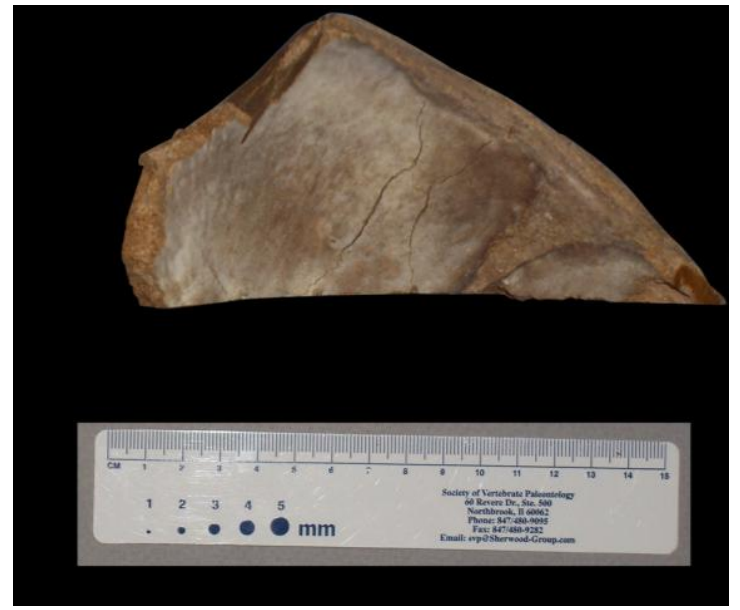

Figure D-23. View of acetablulum of pelvis of Tualatin Mammut americanum (UO MNCH \# F-30282). 


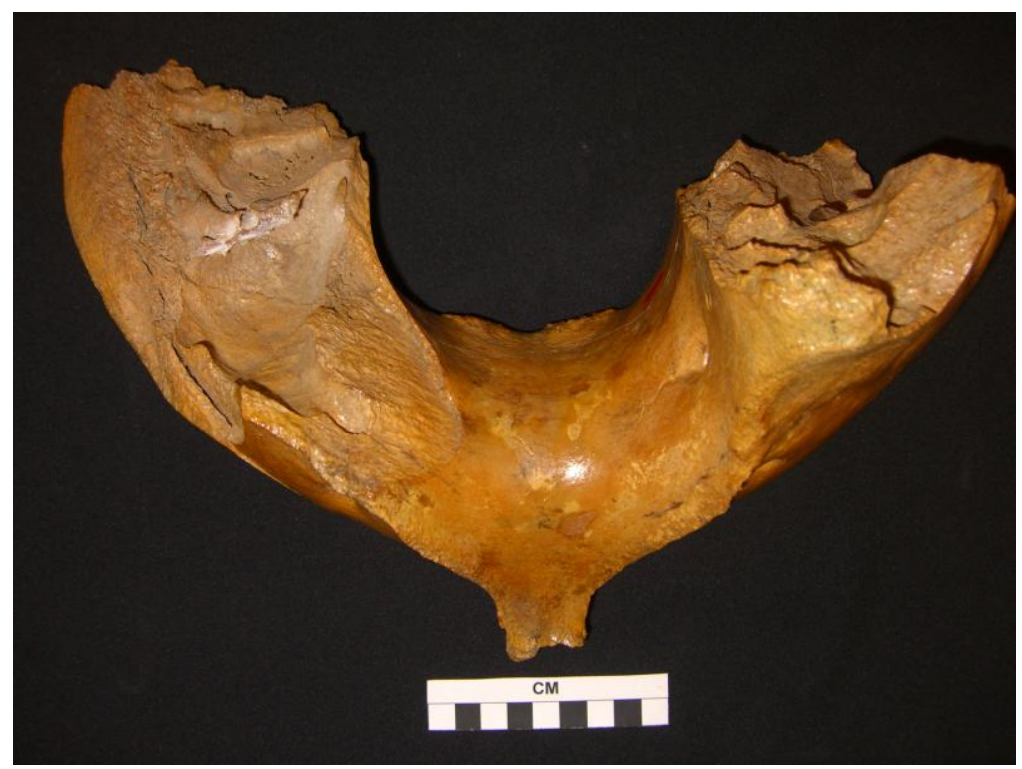

Figure D-24. Dorsal view of mandible of McMinnville Mammuthus columbi (UO MNCH \# pending).

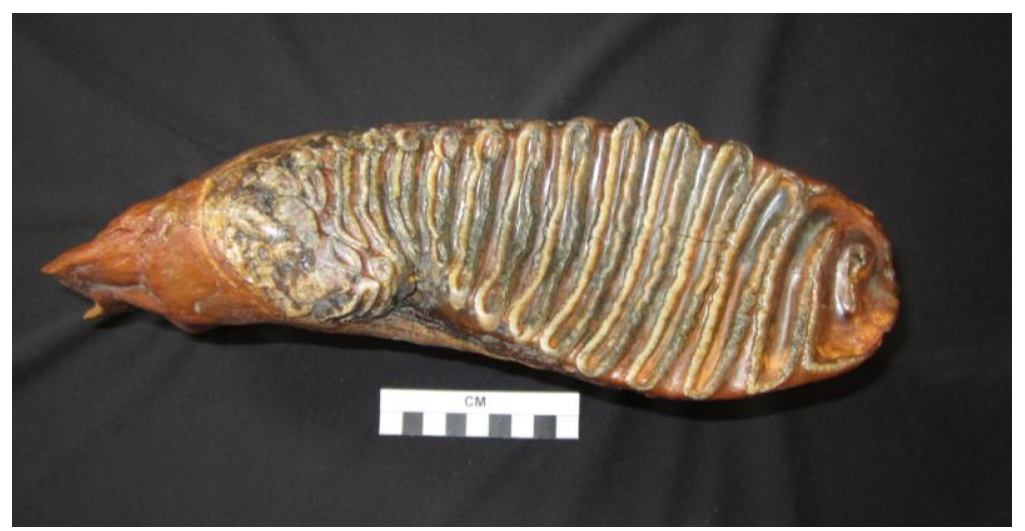

Figure D-25. Dorsal view of occlusal surface of molar of McMinnville Mammuthus columbi (UO MNCH \# pending). This skeletal element was not sampled for specialized analyses, but taxonomic assignment was based upon character of molars.

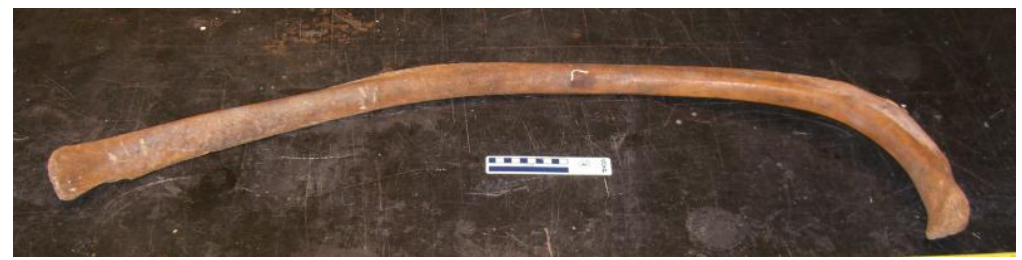

Figure D-26. Ventral view of rib of Hillsboro Mammuthus sp. (UO MNCH \# F-29247). 


\section{APPENDIX E: Metric Documentation of Fossil Material}

Table E-1. Measurements of Hillsboro Locality (UO 2666) bison cranium (Bison antiquus - UO MNCH \# F-29240)

\begin{tabular}{|c|c|c|c|}
\hline & Measure & Reference & $\begin{array}{l}\text { Measurement } \\
\text { (millimeters) }\end{array}$ \\
\hline 1 & Spread of horn cores, tip to tip & McDonald 1981:43-47 & 911 \\
\hline 3 & $\begin{array}{l}\text { Horn core length, upper curve, tip to } \\
\text { burr }\end{array}$ & McDonald 1981:43-47 & 265 \\
\hline 5 & $\begin{array}{l}\text { Straight line distance, tip to burr, dorsal } \\
\text { horn core }\end{array}$ & McDonald 1981:43-47 & 249 \\
\hline 6 & Dorso-ventral diameter, horn core base & McDonald 1981:43-47 & 124 \\
\hline 7 & $\begin{array}{l}\text { Minimum circumference, horn core } \\
\text { base }\end{array}$ & McDonald 1981:43-47 & 366 \\
\hline 8 & Width of occipital at auditory openings & McDonald 1981:43-47 & 302 \\
\hline 9 & Width of occipital condyles & McDonald 1981:43-47 & 154 \\
\hline 10 & $\begin{array}{l}\text { Depth, nuchal line to dorsal margin of } \\
\text { foramen magnum }\end{array}$ & McDonald 1981:43-47 & 126 \\
\hline 12 & $\begin{array}{l}\text { Antero-posterior diameter, horn core } \\
\text { base }\end{array}$ & McDonald 1981:43-47 & 118 \\
\hline 14 & $\begin{array}{l}\text { Least width of frontals, between horn } \\
\text { cores and orbits }\end{array}$ & McDonald 1981:43-47 & 348 \\
\hline 15 & Greatest width of frontals at orbits & McDonald 1981:43-47 & 386 \\
\hline$\angle 21$ & $\begin{array}{l}\text { Angle of divergence of horn cores, } \\
\text { forward from sagittal }\end{array}$ & McDonald 1981:43-47 & $84^{\circ}$ \\
\hline
\end{tabular}

Table E-2. Measurements of Woodburn High School Locality (UO 2596) bison cranium (Bison antiquus - UO MNCH \# F-42801)

\begin{tabular}{|c|c|c|c|}
\hline & Measure & Reference & $\begin{array}{l}\text { Measurement } \\
\text { (millimeters) }\end{array}$ \\
\hline 1 & Spread of horn cores, tip to tip & McDonald 1981:43-47 & 910 \\
\hline 3 & $\begin{array}{l}\text { Horn core length, upper curve, tip to } \\
\text { burr }\end{array}$ & McDonald 1981:43-47 & 279 \\
\hline 5 & $\begin{array}{l}\text { Straight line distance, tip to burr, dorsal } \\
\text { horn core }\end{array}$ & McDonald 1981:43-47 & 241 \\
\hline 6 & Dorso-ventral diameter, horn core base & McDonald 1981:43-47 & 99 \\
\hline 7 & $\begin{array}{l}\text { Minimum circumference, horn core } \\
\text { base }\end{array}$ & McDonald 1981:43-47 & 307 \\
\hline 8 & Width of occipital at auditory openings & McDonald 1981:43-47 & 349 \\
\hline 9 & Width of occipital condyles & McDonald 1981:43-47 & 151 \\
\hline 10 & $\begin{array}{l}\text { Depth, nuchal line to dorsal margin of } \\
\text { foramen magnum }\end{array}$ & McDonald 1981:43-47 & 98 \\
\hline 12 & $\begin{array}{l}\text { Antero-posterior diameter, horn core } \\
\text { base }\end{array}$ & McDonald 1981:43-47 & 91 \\
\hline 14 & $\begin{array}{l}\text { Least width of frontals, between horn } \\
\text { cores and orbits }\end{array}$ & McDonald 1981:43-47 & 333 \\
\hline 15 & Greatest width of frontals at orbits & McDonald 1981:43-47 & 414 \\
\hline$\angle 21$ & $\begin{array}{l}\text { Angle of divergence of horn cores, } \\
\text { forward from sagittal }\end{array}$ & McDonald 1981:43-47 & $82^{\circ}$ \\
\hline
\end{tabular}


Table E-3. Measurements of Woodburn-Legion Park (UO 3038, 3064, \& 3867) bison

$2^{\text {nd }}$ phalanx (Bison sp. - UO MNCH \# F-38522)

\begin{tabular}{|c|c|c|c|}
\hline & Measure & Reference & $\begin{array}{l}\text { Measurement } \\
\text { (millimeters) }\end{array}$ \\
\hline Gl & Greatest length & von den Driesch 1976:98-99 & 54.06 \\
\hline $\mathrm{Bp}$ & $\begin{array}{l}\text { (Greatest) breadth of the proximal } \\
\text { end }\end{array}$ & von den Driesch 1976:98-99 & 44.42 \\
\hline $\mathrm{SD}$ & Smallest breadth of the diaphysis & von den Driesch 1976:98-99 & 34.08 \\
\hline $\mathrm{Bd}$ & (Greatest) breadth of the distal end & von den Driesch 1976:98-99 & 39.65 \\
\hline
\end{tabular}

Table E-4. Measurements of Woodburn-Legion Park (UO 3038, 3064, \& 3867) bison mandible (Bison sp. - UO MNCH \# F-40523)

\begin{tabular}{lcc}
\hline Measure & Reference & $\begin{array}{c}\text { Measurement } \\
\text { (millimeters) }\end{array}$ \\
\hline Maximum height & $\mathrm{n} / \mathrm{a}$ & $-134.43^{*}$ \\
Maximum width & $\mathrm{n} / \mathrm{a}$ & 84.59 \\
Maximum thickness & $\mathrm{n} / \mathrm{a}$ & 12.88 \\
\hline
\end{tabular}

* A negative measure indicates that the measurement is a minimum as the skeletal element is incomplete.

Table E-5. Measurements of Woodburn-Legion Park (UO 3038, 3064, \& 3867) bison scapula (Bison sp. - UO MNCH \# F-40527)

\begin{tabular}{llll}
\hline \multicolumn{2}{c}{ Measure } & Reference & $\begin{array}{l}\text { Measurement } \\
\text { (millimeters) }\end{array}$ \\
\hline HS & Height along the spine & von den Driesch 1976:74-75 & $-109.89 *$ \\
Ld & (Greatest) dorsal length & von den Driesch 1976:74-75 & $-90.09 *$ \\
\hline$*$ A negative measure indicates that the measurement is a minimum as the skeletal element is incomplete.
\end{tabular}

Table E-6. Measurements of McMinnville Bison Locality (UO pending) bison femur (Bison sp. - UO MNCH \# F-pending)

\begin{tabular}{llll}
\hline & Measure & Reference & $\begin{array}{l}\text { Measurement } \\
\text { (millimeters) }\end{array}$ \\
\hline 1 & $\begin{array}{l}\text { Approximate rotational length of the } \\
\text { bone }\end{array}$ & McDonald 1981: 44-51 & $-342^{*}$ \\
2 & $\begin{array}{l}\text { Antero-posterior diameter of } \\
\text { diaphysis at right angles to the } \\
\text { transverse minimum }\end{array}$ & McDonald 1981: 44-51 & 52.68 \\
3 & $\begin{array}{l}\text { Transverse minimum of diaphysis } \\
*\end{array}$ & McDonald 1981: 44-51 & 52.04 \\
\hline A negative measure indicates that the measurement is a minimum as the skeletal element is incomplete.
\end{tabular}


Table E-7. Measurements of Woodburn-Legion Park (UO 3038, 3064, \& 3867) horse terminal phalanx (Equus sp. - UO MNCH \# F-37000)

\begin{tabular}{|c|c|c|c|}
\hline & Measure & Reference & $\begin{array}{l}\text { Measuremen } \\
\text { (millimeters) }\end{array}$ \\
\hline 1 & $\begin{array}{l}\text { Length from the posterior edge of } \\
\text { the articular surface to the tip of } \\
\text { the phalanx }\end{array}$ & Eisenmann et al. 1988:68-69 & 58.38 \\
\hline 2 & Anterior length & Eisenmann et al. 1988:68-69 & $-49.16^{*}$ \\
\hline 3 & Maximal breadth & Eisenmann et al. 1988:68-69 & 73.44 \\
\hline 4 & Articular breadth & Eisenmann et al. 1988:68-69 & 50.46 \\
\hline 5 & Articular depth & Eisenmann et al. 1988:68-69 & 28.85 \\
\hline 6 & Maximal height & Eisenmann et al. 1988:68-69 & 42.63 \\
\hline 7 & $\begin{array}{l}\text { Angle between the sole and the } \\
\text { dorsal line }\end{array}$ & Eisenmann et al. 1988:68-69 & $47.5^{\circ}$ \\
\hline 8 & "Circumference" of the sole & Eisenmann et al. 1988:68-69 & 18.70 \\
\hline- & Maximal depth & Eisenmann et al. 1988:68-69 & 65.78 \\
\hline
\end{tabular}

Table E-8. Measurements of Woodburn-Legion Park (UO 3038, 3064, \& 3867) horse astragalus (Equus sp. - UO MNCH \# F-38518)

\begin{tabular}{|c|c|c|c|}
\hline & Measure & Reference & $\begin{array}{l}\text { Measurement } \\
\text { (millimeters) }\end{array}$ \\
\hline 1 & Maximal length & Eisenmann et al. 1988:56-57 & 71.35 \\
\hline 2 & $\begin{array}{l}\text { Maximal diameter of the medial } \\
\text { condyle }\end{array}$ & Eisenmann et al. 1988:56-57 & 62.23 \\
\hline 3 & Breadth of the trochlea & Eisenmann et al. 1988:56-57 & 37.60 \\
\hline 4 & Maximal breadth & Eisenmann et al. 1988:56-57 & 81.77 \\
\hline 5 & Distal articular surface & Eisenmann et al. 1988:56-57 & 66.52 \\
\hline 6 & Distal articular depth & Eisenmann et al. 1988:56-57 & 43.75 \\
\hline 7 & Maximal medial depth & Eisenmann et al. 1988:56-57 & $-50.66^{*}$ \\
\hline- & $\begin{array}{l}\text { Maximal length from the medial } \\
\text { condyle to the most distal point on } \\
\text { the lateral part of the distal } \\
\text { articular surface }\end{array}$ & Eisenmann et al. 1988:56-57 & 59.91 \\
\hline
\end{tabular}

* A negative measure indicates that the measurement is a minimum as the skeletal element is incomplete. 
Table E-9. Measurements of Hillsboro Locality (UO 2666) sloth femur (Paramylodon harlani - UO MNCH \# F-29242)

\begin{tabular}{|c|c|c|c|}
\hline & Measure & Reference & $\begin{array}{l}\text { Measurement } \\
\text { (millimeters) }\end{array}$ \\
\hline GL & Greatest length & von den Driesch 1976:84-85 & 559 \\
\hline GLC & $\begin{array}{l}\text { Greatest length from caput } \\
\text { femoris (head) }\end{array}$ & von den Driesch 1976:84-85 & 559 \\
\hline Bp & $\begin{array}{l}\text { (Greatest) breadth of proximal } \\
\text { end }\end{array}$ & von den Driesch 1976:84-85 & 297 \\
\hline $\mathrm{BTr}$ & $\begin{array}{l}\text { (Greatest) breadth of the region } \\
\text { of the Trochanter tertius }\end{array}$ & von den Driesch 1976:84-85 & 273 \\
\hline DC & $\begin{array}{l}\text { (Greatest) depth of the Caput } \\
\text { femoris }\end{array}$ & von den Driesch 1976:84-85 & 126 \\
\hline $\mathrm{SD}$ & Smallest breadth of diaphysis & von den Driesch 1976:84-85 & 189 \\
\hline $\mathrm{CD}$ & $\begin{array}{l}\text { (Smallest) circumference of } \\
\text { diaphysis }\end{array}$ & von den Driesch 1976:84-85 & 454 \\
\hline $\mathrm{Bd}$ & $\begin{array}{l}\text { (Greatest) breadth of the distal } \\
\text { end }\end{array}$ & von den Driesch 1976:84-85 & 201 \\
\hline
\end{tabular}

Table E-10. Measurements of Tualatin River-Fanno Creek Locality (UO pending) sloth synsacrum (Paramylodon harlani - UO MNCH \# F-pending)

\begin{tabular}{|c|c|c|c|}
\hline & Measure & Reference & $\begin{array}{l}\text { Measurement } \\
\text { (millimeters) }\end{array}$ \\
\hline GL & $\begin{array}{l}\text { Greatest length of the ventral side: from } \\
\text { the cranial borders of the wings to the } \\
\text { caudoventral border of the body of the last } \\
\text { vertebra }\end{array}$ & $\begin{array}{l}\text { von den Driesch } \\
1976: 71\end{array}$ & $\mathrm{n} / \mathrm{a}$ \\
\hline PL & $\begin{array}{l}\text { Physiological length, measured between } \\
\text { the centers of the bodies of the most } \\
\text { cranial and the most caudal vertebrae }\end{array}$ & $\begin{array}{l}\text { von den Driesch } \\
1976: 71\end{array}$ & 381 \\
\hline GB & Greatest breadth (across the wings) & $\begin{array}{l}\text { von den Driesch } \\
\text { 1976:71 }\end{array}$ & 311 \\
\hline BFcr & $\begin{array}{l}\text { (Greatest) breadth of the Facies terminalis } \\
\text { cranialis (=cranial articular surface) }\end{array}$ & $\begin{array}{l}\text { von den Driesch } \\
\text { 1976:71 }\end{array}$ & 139 \\
\hline HFcr & $\begin{array}{l}\text { (Greatest) height of the Facies terminalis } \\
\text { cranialis }\end{array}$ & $\begin{array}{l}\text { von den Driesch } \\
\text { 1976:71 }\end{array}$ & 71 \\
\hline
\end{tabular}

Table E-11. Measurements of McMinnville Sloth (UO pending) humerus (Paramylodon harlani - UO MNCH \# F-pending)

\begin{tabular}{|c|c|c|c|}
\hline & Measure & Reference & $\begin{array}{l}\text { Measurement } \\
\text { (millimeters) }\end{array}$ \\
\hline GL & Greatest length & von den Driesch 1976:76-77 & $-504 *$ \\
\hline GLC & Greatest length from caput (head) & von den Driesch 1976:76-77 & $-493 *$ \\
\hline Bp & $\begin{array}{l}\text { (Greatest) breadth of the proximal } \\
\text { end }\end{array}$ & von den Driesch 1976:76-77 & 201 \\
\hline SD & Smallest breadth of diaphysis & von den Driesch 1976:76-77 & 65 \\
\hline $\mathrm{Bd}$ & (Greatest) breadth of the distal end & von den Driesch 1976:76-77 & 25.6 \\
\hline BT & (Greatest) breadth of the trochlea & von den Driesch 1976:76-77 & 14.5 \\
\hline
\end{tabular}

* A negative measure indicates that the measurement is a minimum as the skeletal element is incomplete. 
Table E-12. Measurements of Tualatin Locality (UO 2840) mastodon pelvis fragment (Mammut americanum - UO MNCH \# F-30282)

\begin{tabular}{cllc}
\hline & Measure & Reference & $\begin{array}{c}\text { Measurement } \\
\text { (millimeters) }\end{array}$ \\
\hline BG & Breadth of the glenoid cavity & von den Driesch 1976a:74-75 & $-117^{*}$ \\
\hline
\end{tabular}

* A negative measure indicates that the measurement is a minimum as the skeletal element is incomplete.

Table E-13. Measurements of McMinnville Mammoth Locality (UO 3067) molars (Mammuthus columbi - UO MNCH \# F-pending)*

\begin{tabular}{llllll}
\hline Molar & $\begin{array}{l}\text { Lamellar } \\
\text { frequency }\end{array}$ & $\begin{array}{l}\text { Number } \\
\text { of } \\
\text { Plates }\end{array}$ & $\begin{array}{l}\text { Mean } \\
\text { Enamel } \\
\text { Thickness }\end{array}$ & Width (cm) & Length (cm) \\
\hline lower left & 7 & 13 & 2.85 & 8.63 & 21.4 \\
upper left & 7 & 11 & 2.87 & 8.96 & 18.8 \\
upper & 8 & 12 & 2.59 & 7.98 & 17.7 \\
right & & & & & \\
\hline
\end{tabular}

* The fragmented mandible of this individual was sampled for the specialized analyses of this study, not these molars. Metrics for the molars are provided as taxonomic assignment was based upon dental characteristics.

Table E-14. Measurements of Hillsboro Locality (UO 2666) mammoth rib (Mammuthus sp. - UO MNCH \# F-29247)

\begin{tabular}{llc} 
Measure & Reference & $\begin{array}{l}\text { Measurement } \\
\text { (millimeters) }\end{array}$ \\
\hline $\begin{array}{l}\text { Linear length from dorsal to ventral tip } \\
\text { Circumference at point of sample } \\
\text { extraction }\end{array}$ & $\mathrm{n} / \mathrm{a}$ & 1084 \\
& $\mathrm{n} / \mathrm{a}$ & 121 \\
\hline
\end{tabular}




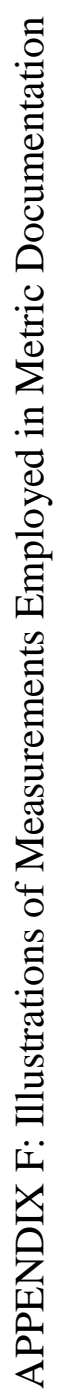
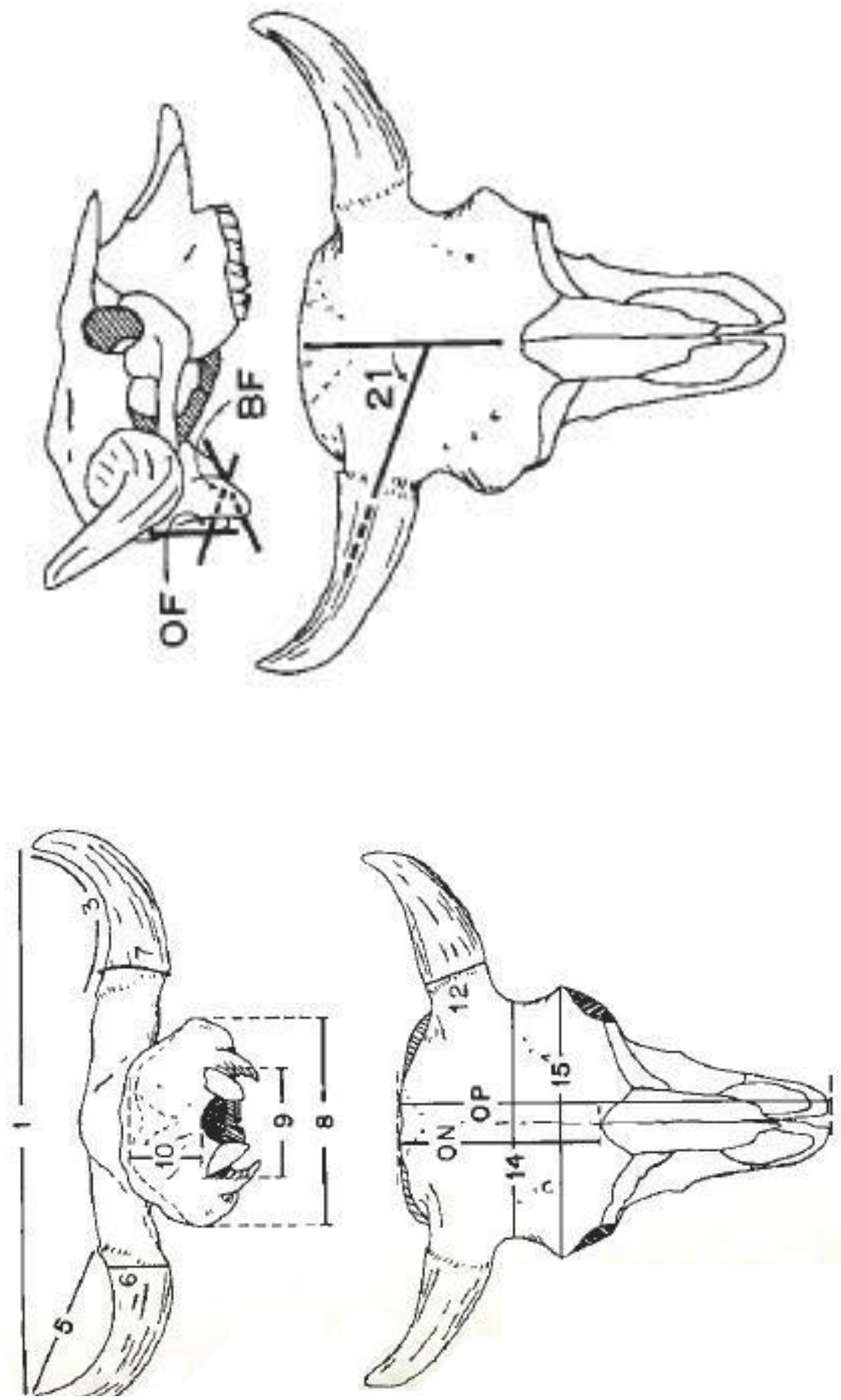


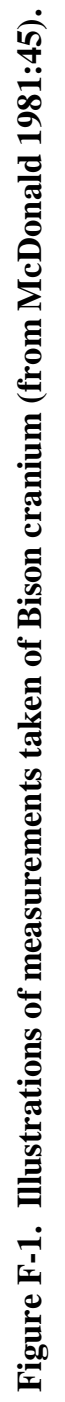
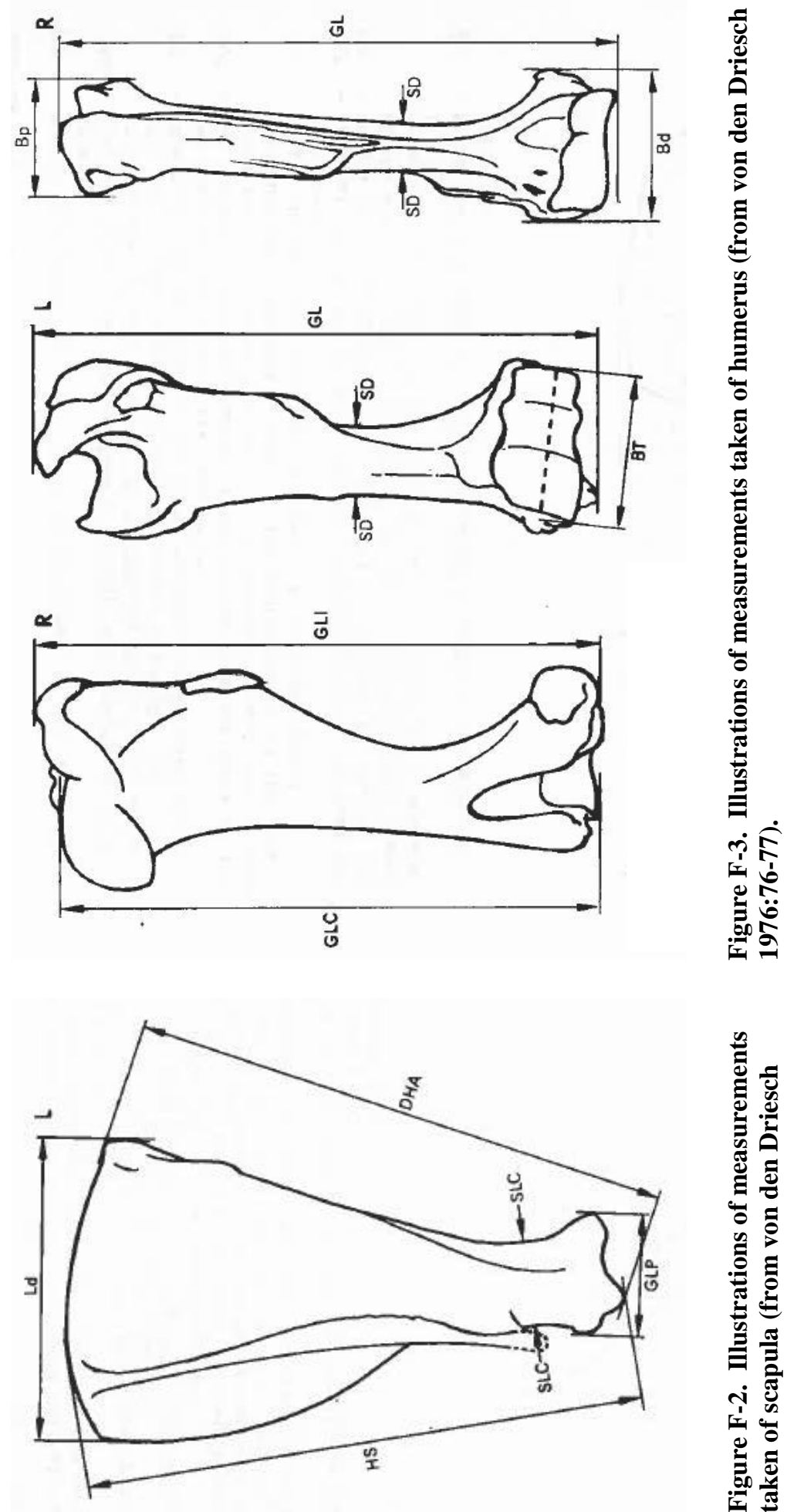

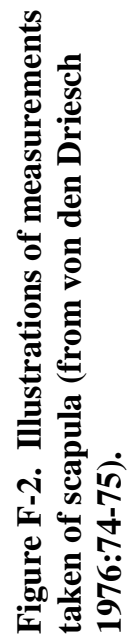



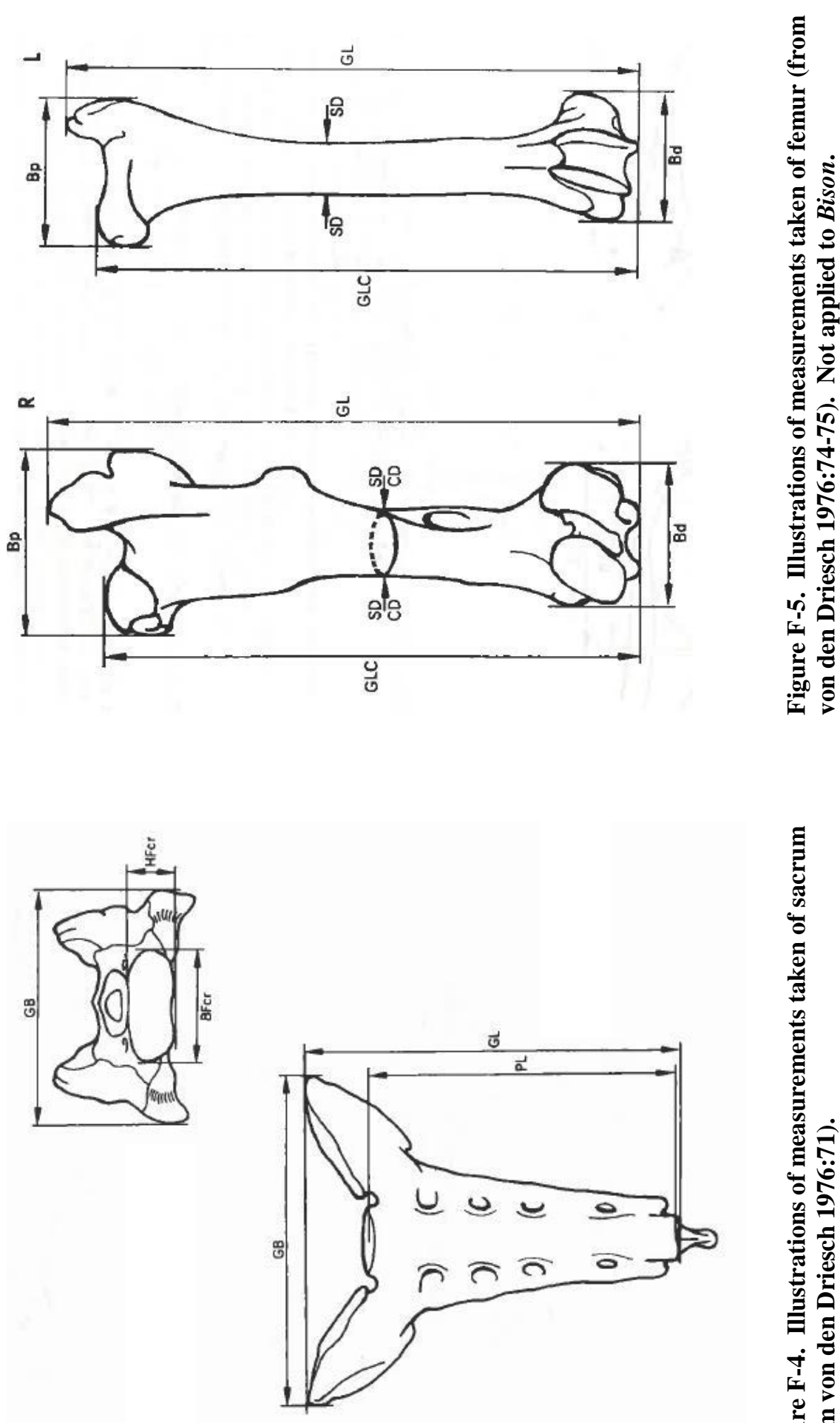

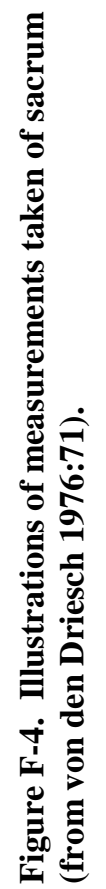




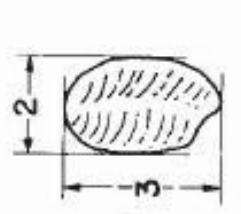

(u)

(ब)

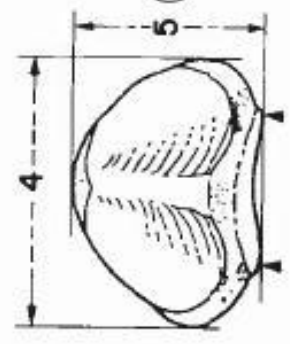

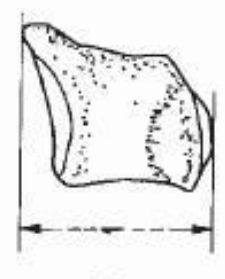

(a)

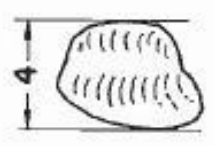

(w)

(๓)

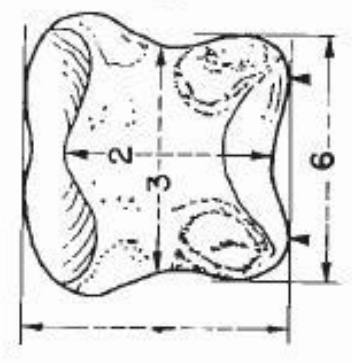

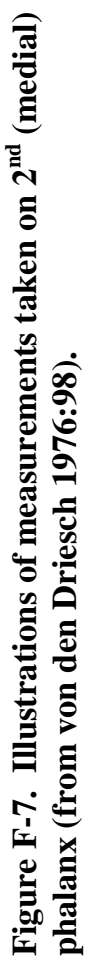
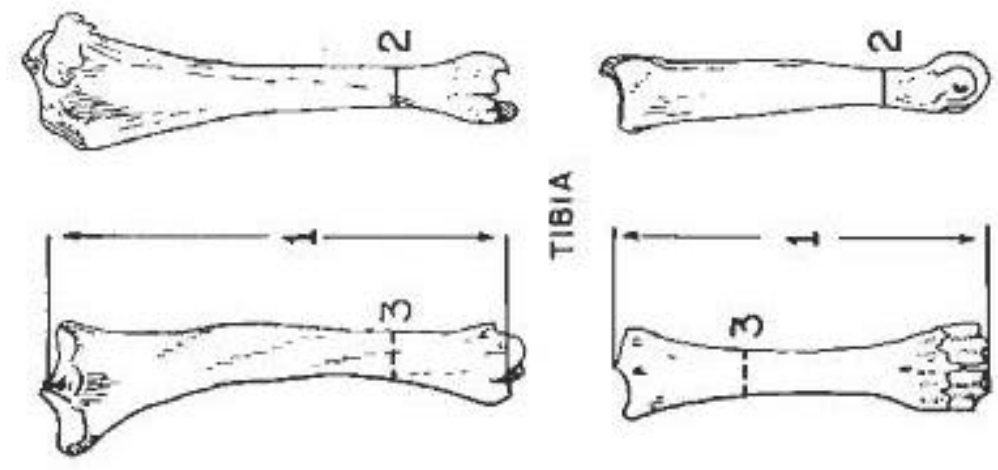

$\stackrel{4}{\underline{\underline{m}}}$
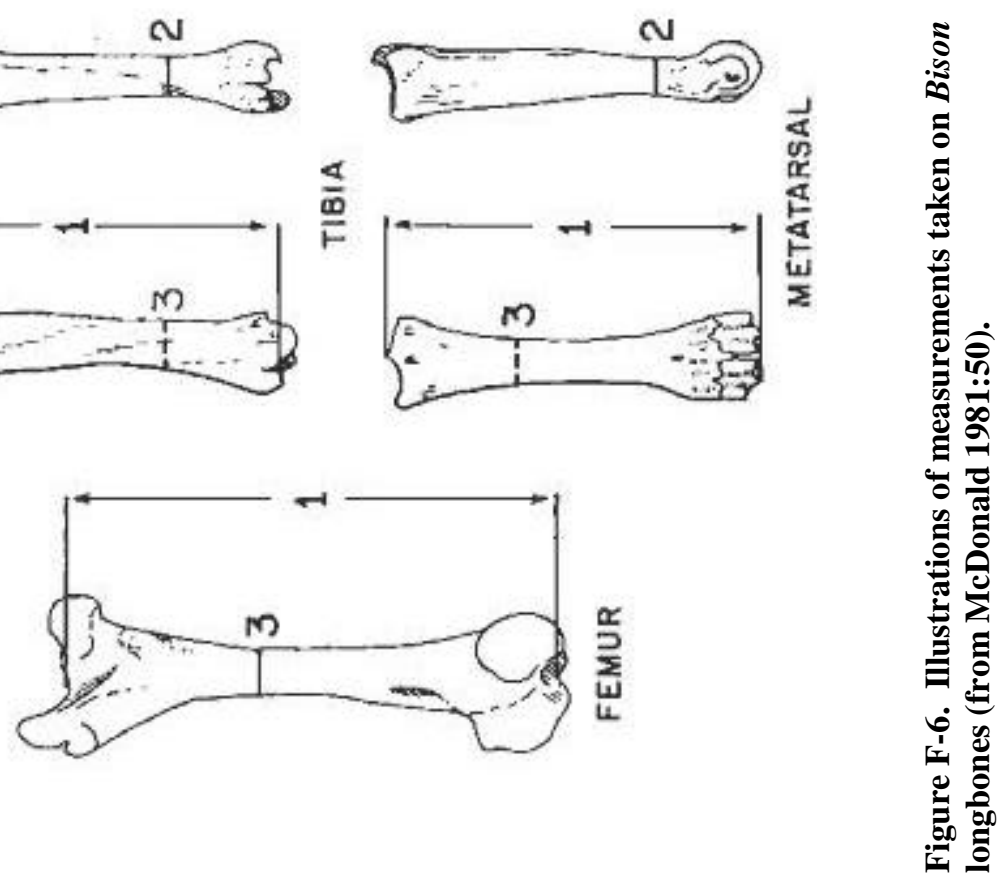

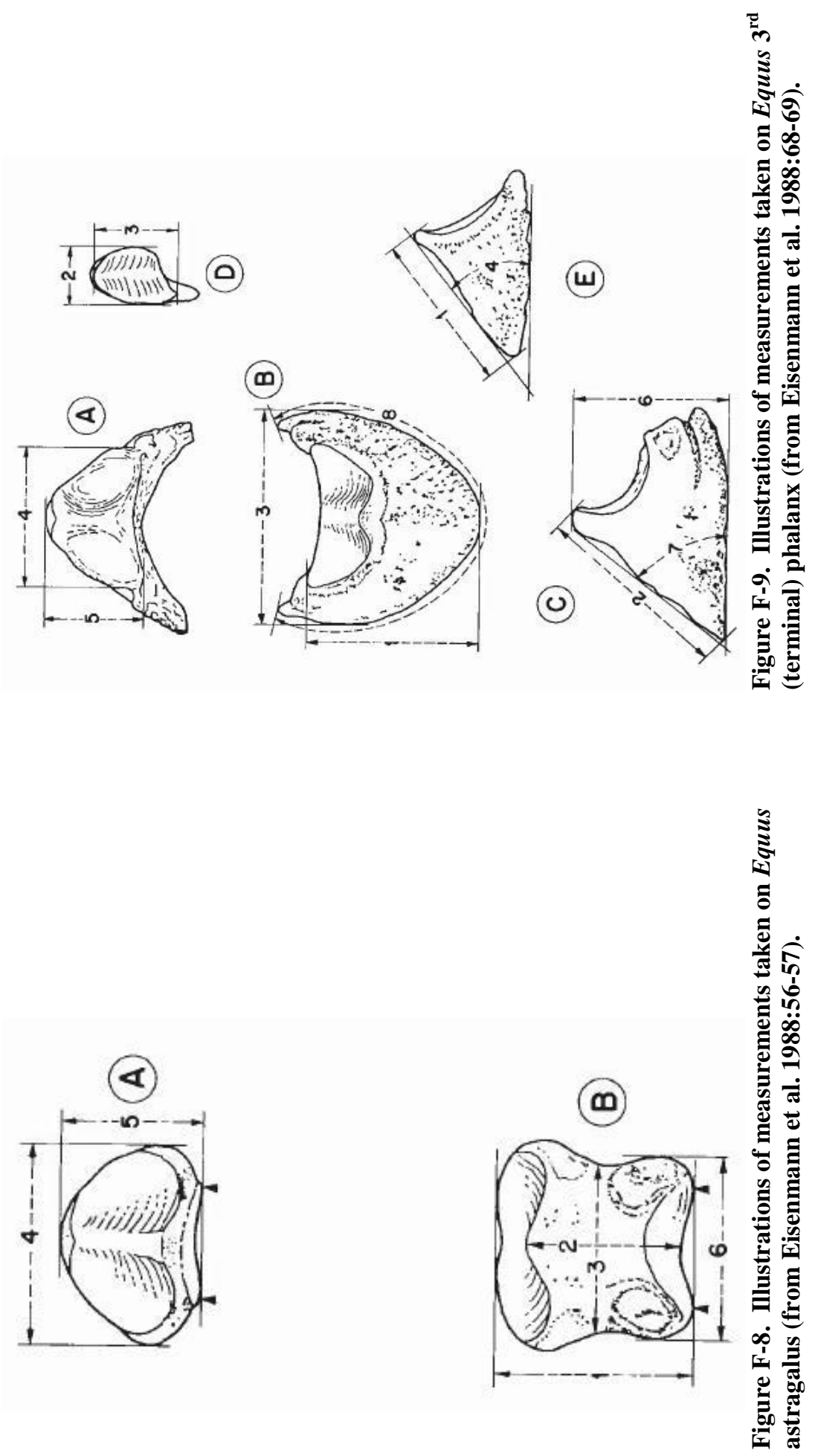


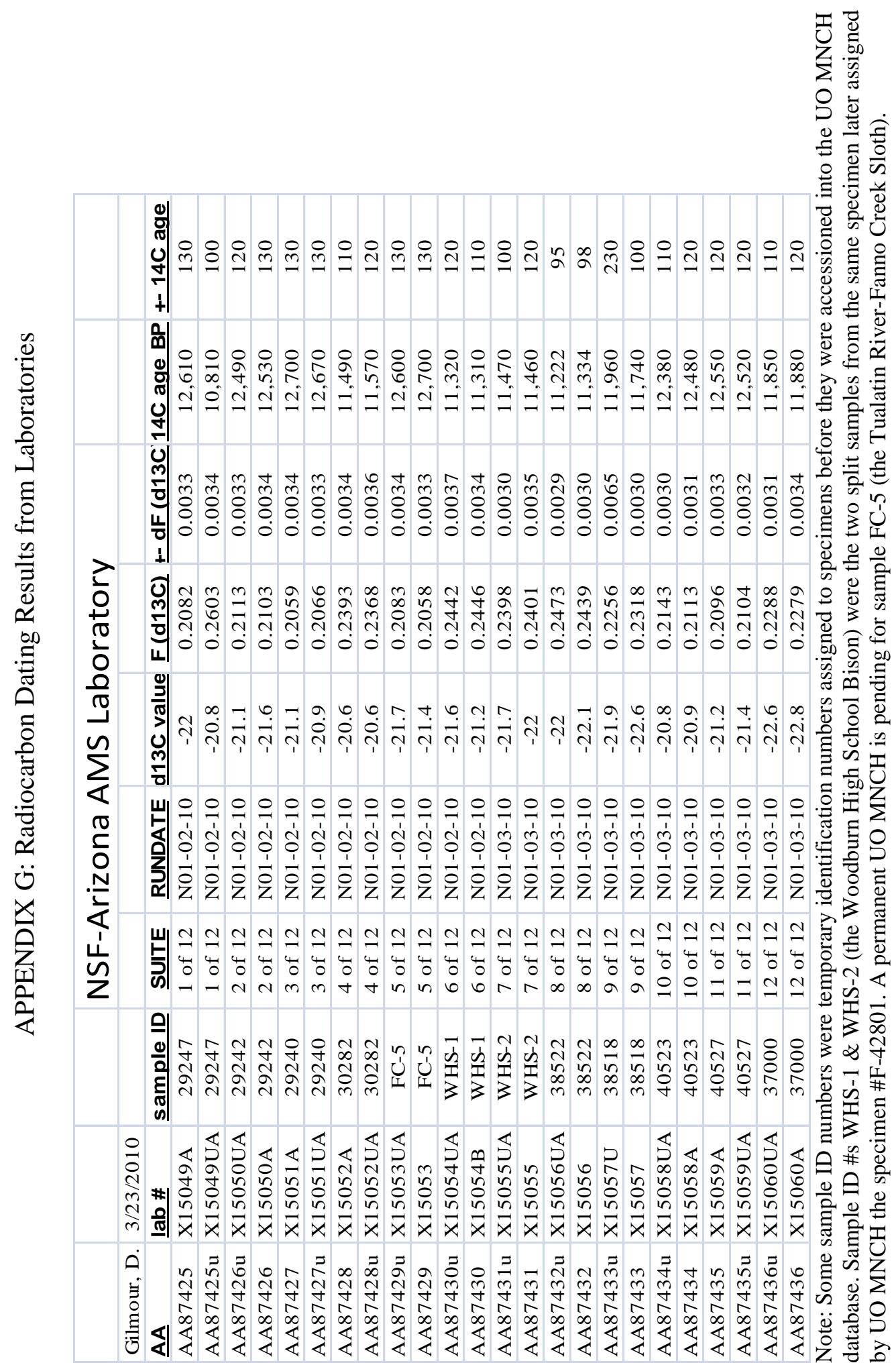




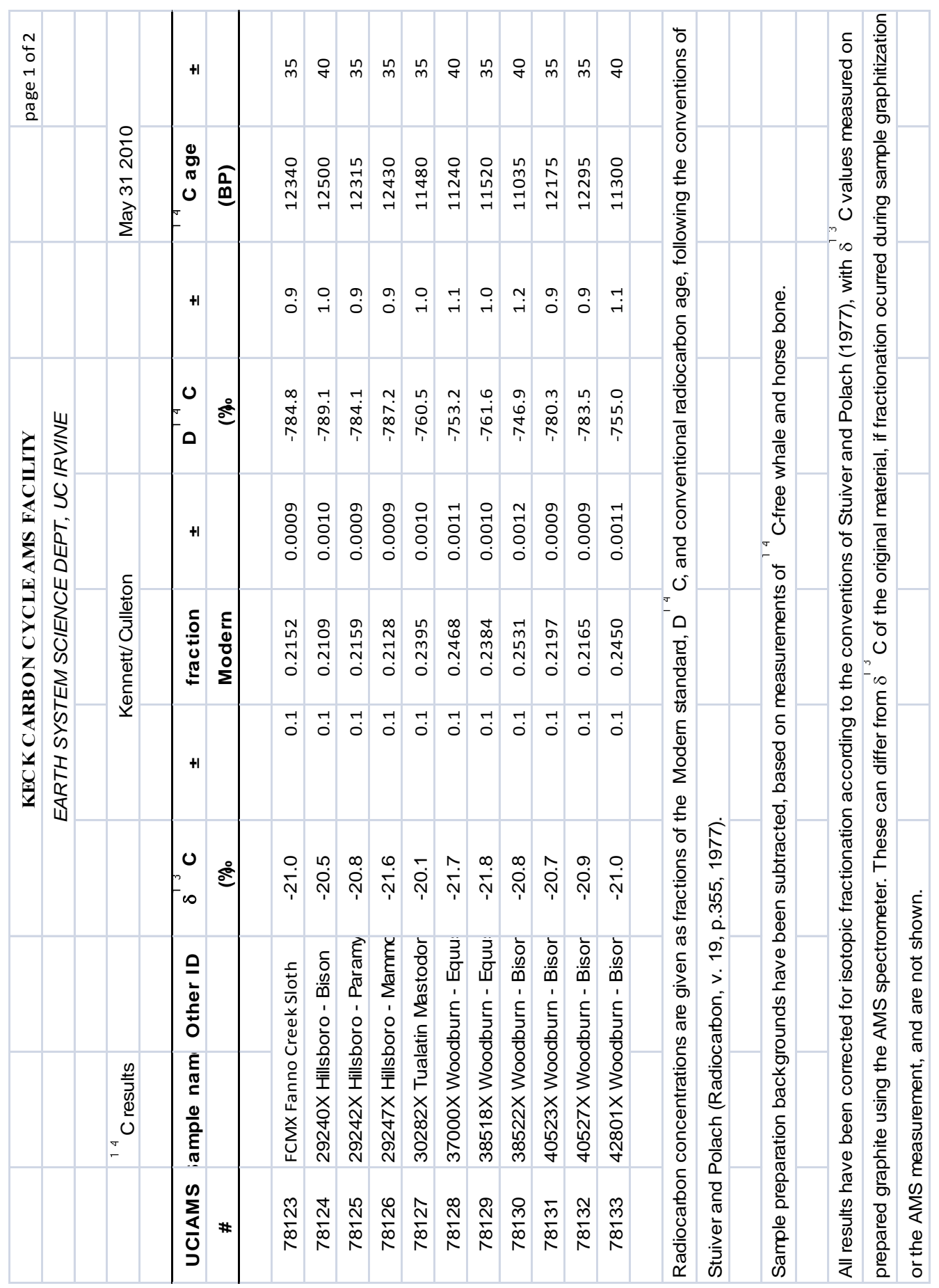




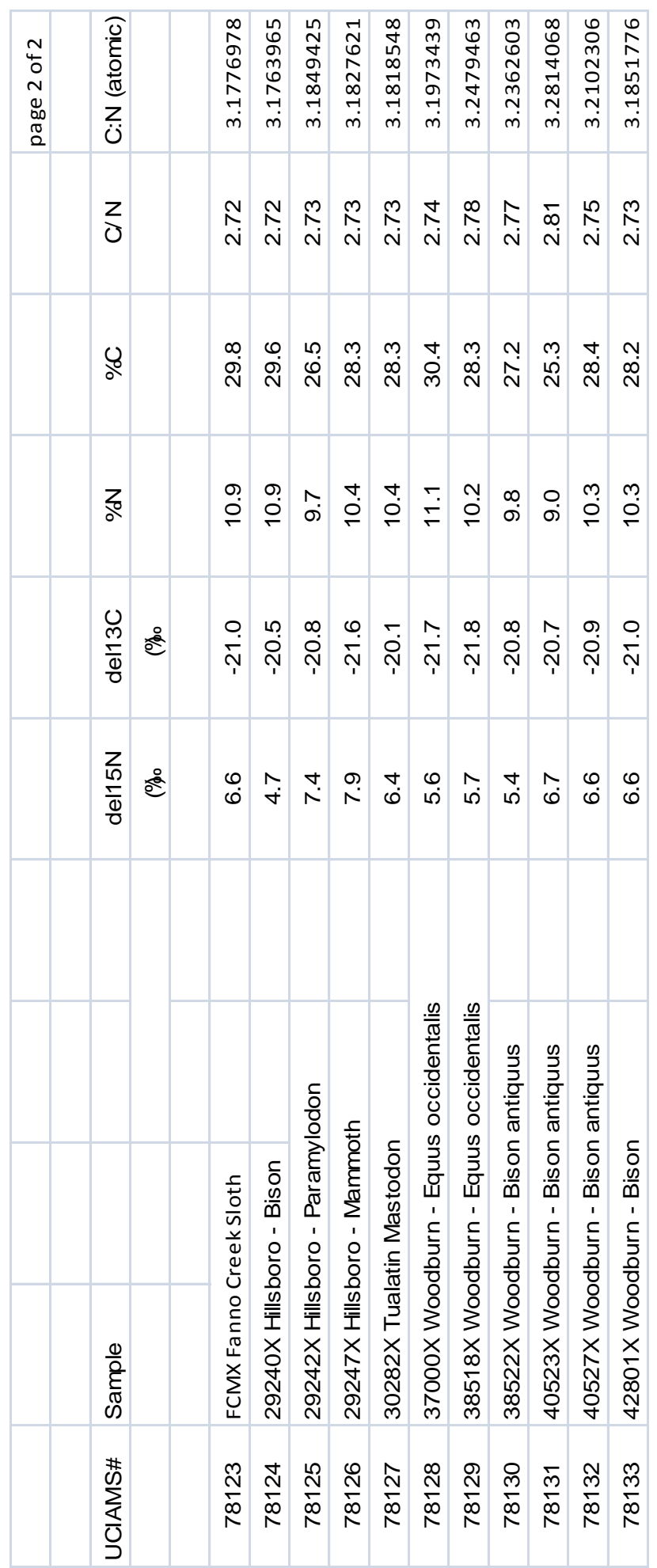




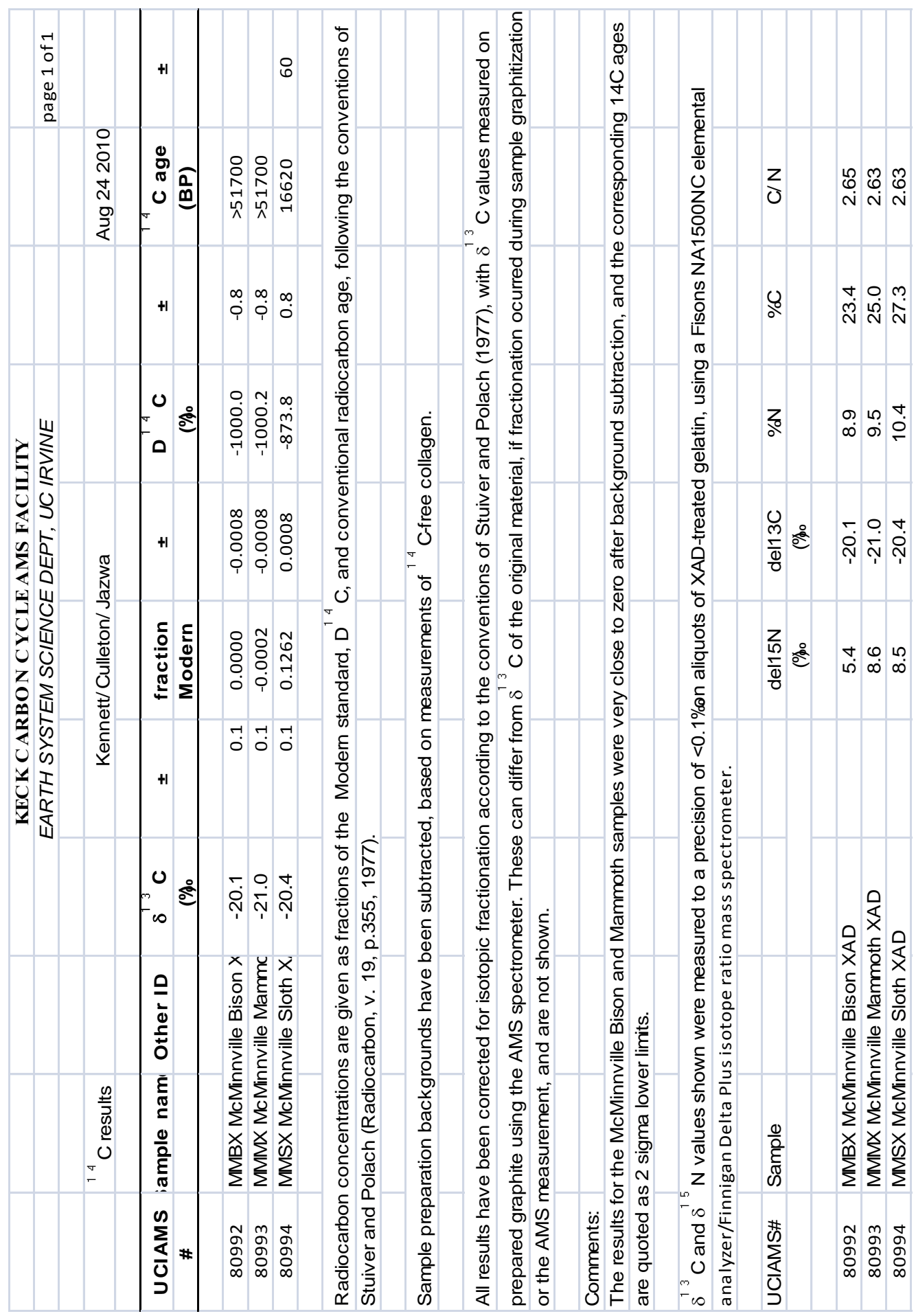


APPENDIX H: XAD-Purification Procedures at the Archaeometry Facility

Protocols employed in the preparation of bone samples must be clearly delineated

as differences in techniques can result in differences in the collagen end product. In order

to ensure accuracy, the method section below is directly copied from the Archaeometry

Facility's manual (Culleton 2011:1-2):

\section{Bone Collagen AMS ${ }^{14} \mathrm{C}$ Dating at University of Oregon: XAD Purification}

Brendan J. Culleton, Deputy Director, UO Archaeometry Facility

Two modern approaches to remove contaminating foreign carbon from bone collagen samples have been in a process of development and refinement over the last two decades: ultrafiltration (Brown et al. 1988) and XAD-purification (Stafford et al. 1988, 1991). Procedures for XAD processing are described in detail below, but a conceptual review of bone dating methods is helpful in understand the technique. Collagen, the protein that provides the organic matrix in which bone is mineralized, comprises roughly $20 \%$ of dry bone by weight, and is the source of carbon used in AMS radiocarbon dating. Since the early decades of radiocarbon dating collagen has been isolated from the inorganic mineral portion of bone by demineralization in dilute acid or, less commonly, by chelation or enzyme digestion (e.g., Berger et al. 1964). Typically the collagen is then treated with a dilute base (e.g., $0.1 \mathrm{~N} \mathrm{NaOH}$ or $\mathrm{KOH}$ ) to extract soil humic and fulvic acids, which are organic compounds identified as the main sources of exogenous carbon contamination in archaeological and paleontological bone. Traditional procedures (e.g, Longin 1971) then gelatinize the collagen in a heated weak $\mathrm{HCl}$ for several hours, lyophilized, and then combusted to produce sample $\mathrm{CO}_{2}$ for AMS ${ }^{14} \mathrm{C}$ dating.

XAD-Purification. Stafford et al. (1988, 1991) argued that gelatinization as described above is not adequate to disassociate all humic and fulvic acids bound to collagen (contra Longin 1971).

If so, it is possible that these foreign contaminants could cross-bind smaller degraded collagen chains into long chains containing exogenous carbon that would be retained even by an ultrafiltration method. The approach to eliminating these contaminants is to break the collagen down to individual amino acids by hydrolysis in strong $(6 \mathrm{~N}) \mathrm{HCl}$, releasing humic and fulvic acids into solution. The hydrolyzate is then passed through a styrene-divinylbenzene (XAD) resin, which is chemically inert but highly adsorptive of ionic contaminants while allowing the purified amino acids to pass through. After drying the hydrolyzate the sample is combusted following standard procedures and sample $\mathrm{CO}_{2}$ is used for $\mathrm{AMS}{ }^{14} \mathrm{C}$ dating. 


\section{Methods}

Bone samples are prepared following the protocols of Stafford et al. $(1988,1991)$ with certain modifications. Bone samples are physically cleaned with an X-Acto blade or similar to remove adhering sediments. Cleaned samples (200-400mg) are placed in $20 \mathrm{~mL}$ scintillation vials and sonicated $15 \mathrm{~min}$ in $4 \mathrm{~mL} \mathrm{1:1}$ acetone:methanol solution to remove lipids, adhesives, inks, etc. and rinsed with DI $\mathrm{H}_{2} \mathrm{O}$. Samples are demineralized for $24-36 \mathrm{hr}$ in $0.5 \mathrm{~N} \mathrm{HCl}$ at $5{ }^{\circ} \mathrm{C}$ followed by a brief $(<1 \mathrm{hr}$ ) alkali bath in $0.1 \mathrm{~N} \mathrm{NaOH}$ at room temperature to remove humates. Collagen is rinsed to neutrality in multiple changes of $\mathrm{DI}_{2} \mathrm{O}$, and then gelatinized for $12 \mathrm{hr}$ at $70{ }^{\circ} \mathrm{C}$ in $0.01 \mathrm{~N} \mathrm{HCl}$. After rinsing to neutrality with DI water percent pseudomorph is observed (cf. Stafford et al. 1988, Table 1), and the sample is lyophilized. Percent collagen yield is determined by weight.

Sample gelatin is pipetted into a pre-cleaned $10 \mathrm{ml}$ disposable syringe with an attached $0.45 \mu \mathrm{m}$ Millex Durapore PVDF filter (precleaned with methanol washes and rinsed with DI) and driven into a thick-walled culture tube. The filtered solution is then lyophilized and \% gelatinization and yield are determined by weight. The sample gelatin is then hydrolyzed in $1.5 \mathrm{~mL} 6 \mathrm{~N} \mathrm{HCl}$ for $22 \mathrm{hr}$ at $110^{\circ} \mathrm{C}$. ENVI-Chrom SPE (Solid Phase Extraction) columns are prepped with 2 washes of methanol $(2 \mathrm{~mL})$ and rinsed with $10 \mathrm{ml} \mathrm{DI} \mathrm{H}_{2} \mathrm{O}$. With a $0.45 \mu \mathrm{m}$ Millex Durapore filter attached, the SPE Column is equilibrated with $50 \mathrm{~mL} 6 \mathrm{~N} \mathrm{HCl}$ and the washings are discarded. $1-5 \mathrm{~mL}$ collagen hydrolyzate as $\mathrm{HCl}$ is pipetted onto the SPE column and driven with an additional $10 \mathrm{ml} 6 \mathrm{~N} \mathrm{HCl}$ dropwise with the syringe into a $20 \mathrm{~mm}$ culture tube. The hydrolyzate is finally dried into a viscous syrup by passing $\mathrm{N}_{2}$ gas over the sample heated at $50^{\circ} \mathrm{C}$ for $\sim 12 \mathrm{hr}$.

\section{Combustion and AMS Measurement.}

Radiocarbon samples ( 4-5 mg of hydrolyzate) are combusted for $3 \mathrm{hr}$ at $800{ }^{\circ} \mathrm{C}$ in vacuum-sealed quartz tubes with $\mathrm{CuO}$ wire and $\mathrm{Ag}$ wire. At KCCAMS, sample $\mathrm{CO}_{2}$ is reduced to graphite at $550^{\circ} \mathrm{C}$ using $\mathrm{H}_{2}$ and a Fe catalyst, with reaction water drawn off with $\mathrm{Mg}\left(\mathrm{ClO}_{4}\right)_{2}$ (Santos et al. 2004). Graphite samples are pressed into targets in Al boats and loaded on the target wheel for AMS analysis. Radiocarbon ages are $\delta^{13} \mathrm{C}$-corrected for mass dependent fractionation with measured ${ }^{14} \mathrm{C} /{ }^{13} \mathrm{C}$ values (Stuiver and Polach 1977), and compared with samples of Pleistocene whale bone (background, $>51 \mathrm{k}{ }^{14} \mathrm{C} \mathrm{BP}$ ), late AD 1800s cow bone, other known age secondaries, and OX-1 oxalic acid standards for calibration. Stable isotope samples ( $0.7 \mathrm{mg}$ ) are analyzed on a Fisons NA1500NC elemental analyzer/Finnigan Delta Plus isotope ratio mass spectrometer with a precision of $<0.1 \%$ for $\delta^{13} \mathrm{C}$ and $\delta^{15} \mathrm{~N}$. Percent $\mathrm{C}, \mathrm{N}$, and $\mathrm{C}$ : $\mathrm{N}$ ratios are reviewed to assess sample integrity. 